\title{
A LATE CRETACEOUS (CENOMANIAN) MARINE VERTEBRATE-RICH BIOCLASTIC HORIZON FROM THE NORTHEASTERN MARGIN OF THE WESTERN INTERIOR SEAWAY, CANADA
}

\author{
Aaron Phillips
}

A thesis submitted to the Faculty of Graduate Studies in partial fulfillment of the requirements for the degree of

Master of Science

Department of Earth Sciences

Carleton University

Ottawa-Carleton Geoscience Centre

Ottawa, Ontario

May 2008

CCopyright 2008, Aaron Phillips 


$\begin{array}{ll}\begin{array}{l}\text { Library and } \\ \text { Archives Canada }\end{array} & \begin{array}{l}\text { Bibliothèque et } \\ \text { Archives Canada }\end{array} \\ \begin{array}{l}\text { Published Heritage } \\ \text { Branch }\end{array} & \begin{array}{l}\text { Direction du } \\ \text { Patrimoine de l'édition }\end{array} \\ \begin{array}{l}\text { 395 Wellington Street } \\ \text { Ottawa ON K1A 0N4 } \\ \text { Canada }\end{array} & \begin{array}{l}\text { 395, rue Wellington } \\ \text { Ottawa ON K1A 0N4 } \\ \text { Canada }\end{array}\end{array}$

Your file Votre référence ISBN: 978-0-494-40661-8 Our file Notre référence ISBN: 978-0-494-40661-8

NOTICE:

The author has granted a nonexclusive license allowing Library and Archives Canada to reproduce, publish, archive, preserve, conserve, communicate to the public by telecommunication or on the Internet, loan, distribute and sell theses worldwide, for commercial or noncommercial purposes, in microform, paper, electronic and/or any other formats.

The author retains copyright ownership and moral rights in this thesis. Neither the thesis nor substantial extracts from it may be printed or otherwise reproduced without the author's permission.
AVIS:

L'auteur a accordé une licence non exclusive permettant à la Bibliothèque et Archives Canada de reproduire, publier, archiver, sauvegarder, conserver, transmettre au public par télécommunication ou par l'Internet, prêter, distribuer et vendre des thèses partout dans le monde, à des fins commerciales ou autres, sur support microforme, papier, électronique et/ou autres formats.

L'auteur conserve la propriété du droit d'auteur et des droits moraux qui protège cette thèse. $\mathrm{Ni}$ la thèse ni des extraits substantiels de celle-ci ne doivent être imprimés ou autrement reproduits sans son autorisation.
In compliance with the Canadian Privacy Act some supporting forms may have been removed from this thesis.

While these forms may be included in the document page count, their removal does not represent any loss of content from the thesis.
Conformément à la loi canadienne sur la protection de la vie privée, quelques formulaires secondaires ont été enlevés de cette thèse.

Bien que ces formulaires aient inclus dans la pagination, il n'y aura aucun contenu manquant.

\section{Canada}




\begin{abstract}
Throughout the Cretaceous Western Canadian Sedimentary Basin, concentrations of the remains of fossilized marine vertebrates \& invertebrates (macrofossils) occur as dense bioclastic and bonebed horizons. In Manitoba and Saskatchewan, Canada, these horizons are particularly abundant within the Belle Fourche Member of the Ashville Formation, deposited along the eastern margin of the Cenomanian Western Interior Seaway (WIS). Concentrations of abundant bones, teeth, and scales of marine and, very rarely, terrestrial, vertebrates are found along with bivalve-rich horizons such as the regionally wide-spread Ostrea beloiti layer along the length of the Manitoba Escarpment.

A newly discovered locality near the southern end of the escarpment has yielded calcarenites, composed primarily of inoceramid-derived calcitic prisms and abundant, disarticulated marine vertebrate elements and microcoprolites, as well as oyster valves. Stratigraphically, these deposits are believed to be of early Middle Cenomanian age, originating lower in the Belle Fourche Member than previously described marine vertebrate bonebeds from the region.
\end{abstract}

The preserved vertebrate fossils reveal a diverse paleocommunity comprised of 12 chondrichthyan taxa, 13 osteichthyan taxa, and 2 reptilian taxa. Several of these, including Protosphyraena sp., Squalicorax falcatus, a salmoniform, Xiphactinus audax, Enchodus cf. E. gladiolus, Enchodus cf. E. petrosus, and Enchodus cf. E. shumardi represent earliest occurrences of these taxa in Canada and/or North America, as well as what may be the earliest evidence of eels (Order Anguilliformes) on this continent.

Taphonomic data indicates that the bioclasts were concentrated by physical processes such as winnowing, as well as by the siliciclastically-starved setting of the 
eastern margin of the WIS. Evidence of minor transportation, winnowing, and reworking are taken to indicate these bioclastic sediments were initially deposited relatively further offshore than other bonebeds known from the Manitoba Escarpment, at or just beneath storm wave base. Petrographic study of the bonebeds reveals that variability in the amount of inoceramid-derived prismatic calcite buried along with the concentrated vertebrate bioclasts may have affected the timing of cementation, and therefore the susceptibility of these deposits to further reworking.

Comparison with skeletal limestones known from the Greenhorn Limestone in the United States suggests that the calcarenites studied here were deposited in a similar manner: as the result of storms (i.e. as tempestites) impinging on the extremely shallowly sloping sea floor of the eastern margin of the Western Interior Seaway, during one of the frequent oscillations of sea-level during the Cenomanian. Cretaceous marine bioclastic and bonebed horizons are widespread in the WIS and may eventually serve as stratigraphic and sequence stratigraphic markers integrated into a basinwide framework. 


\section{ACKNOWLEDGEMENTS}

Sincere thanks go to my supervisors Dr. Stephen L. Cumbaa and Dr. Claudia Schröder-Adams for an excellent and challenging M.Sc. project, as well as for their unwavering guidance, instruction, patience and support throughout this project. Steve's energy and enthusiasm for fossil fishes, and Claudia's untiring pursuit of "the big picture" in the WIS, were inspirational. Research funding for this project was supplied by NSERC Discovery Grants to Dr S. L. Cumbaa and Dr. C. Schröder-Adams. I would also like to thank Mr. and Mrs. Henry Van der Voort of Riding Mountain, MB, and Dwayne and Debbie Unger of Kelwood, $\mathrm{MB}$, for access to the site that was so pivotal to my research. Thanks also go to the Manitoba Museum and the Royal Saskatchewan Museum for access to my study material. Special thanks go out to the 2006 Field Party; especially Richard Day, for his wisdom both technical and practical. Further thanks are due to Glenn Poirier at the CMN, who gave freely of his time and expertise on the SEM and the microprobe, and to James Haggart of the GSC for his efforts to identify our mysterious molluscs. The students, faculty and staff of the Earth Sciences Dept. at Carleton University also deserve thanks, many having contributed in some way, with special thanks to David Mans in particular. Dave's work ethic was inspirational (however much it actually rubbed off on me), and one couldn't have asked for a better "comrade-inarms". Eternal gratitude goes out to my parents and my sisters, whose unconditional love, encouragement, and support has always been felt no matter where in the country I may be. Last but by no means least, from the very bottom of my heart I extend thanks to Julie Gundry for her love, patience, support, encouragement, sacrifice, humour and inspiration, which have helped this project come to fruition in ways too numerous to count. 


\section{TABLE OF CONTENTS}

THESIS ACCEPTANCE.

.. $\mathrm{i}$

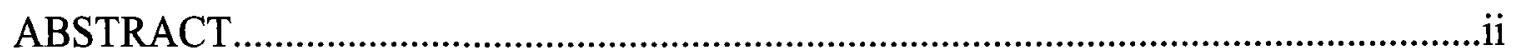

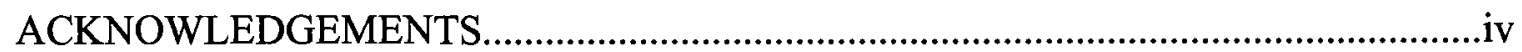

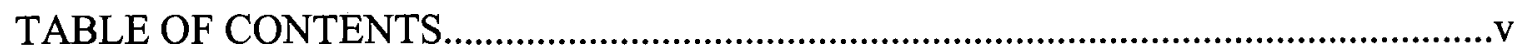

LIST OF FIGURES..............................................................................................ii

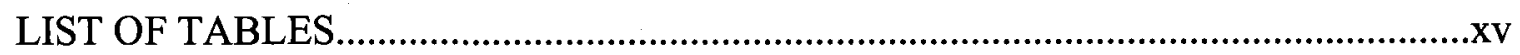

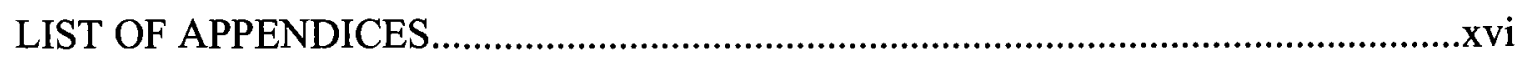

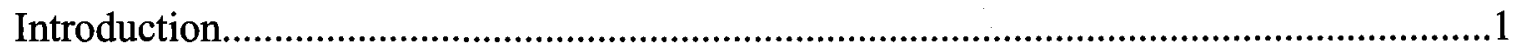

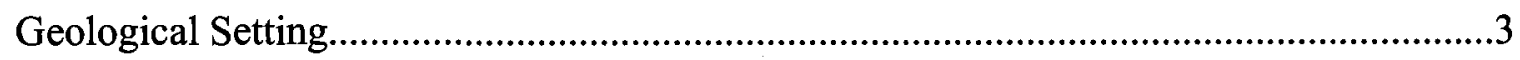

The Western Canadian Sedimentary Basin................................................................

Tectonic Setting and Basin Architecture..............................................................

Patterns of Sedimentation............................................................................

The Late Cretaceous Western Interior Seaway..........................................................

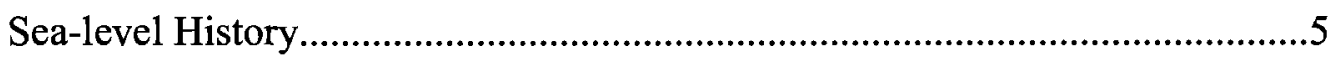

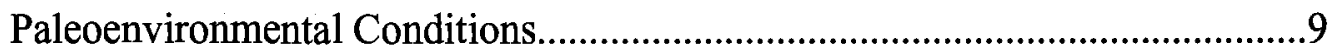

The Manitoba Escarpment....................................................................................10

Stratigraphic Relationships of The Belle Fourche Member...............................12

Lower Belle Fourche Member of the Ashville Formation...................14

Regional Correlation and Significance of the "Fish Scale Marker Beds" ......................................................14

Lithology and Biostratigraphy..........................................................15

Depositional Environment of the Fish Scales Formation...........18 
Upper Belle Fourche Member................................................................19

Bio- and Chronostratigraphy..............................................................19

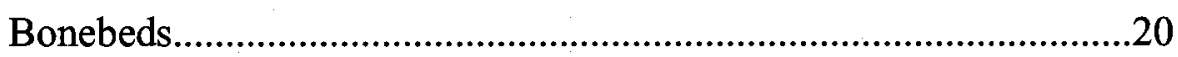

Stratigraphic Placement of Bonebeds................................................21

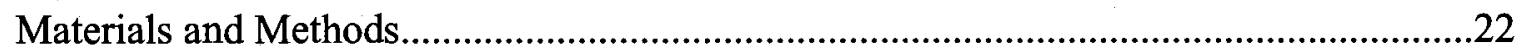

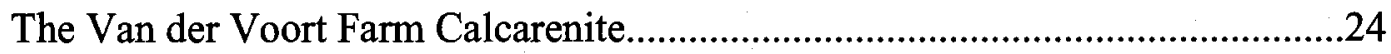

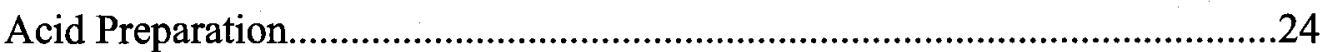

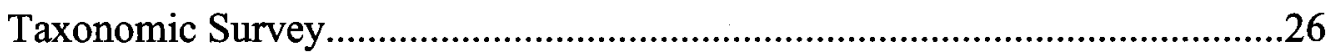

Comparative Taphonomic Census..................................................................27

Size.

Shape

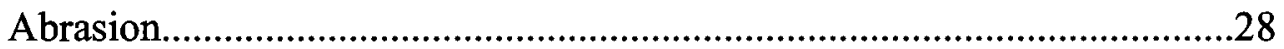

Faunal Diversity and Abundance.................................................................

Petrographic Analysis.....................................................................................

Electron Microprobe Analysis and Scanning Electron Microscopy............31

Petrographic Point Count Analysis.................................................................31

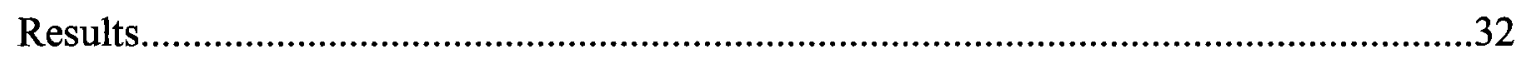

Surficial Description of the Van der Voort Farm Calcarenites................................32

Systematic Paleontology...................................................................................

Comparative Taphonomic Census.......................................................................77

Shape

Size

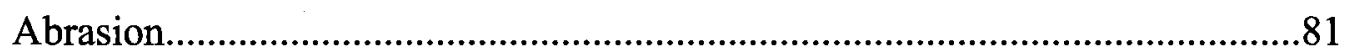




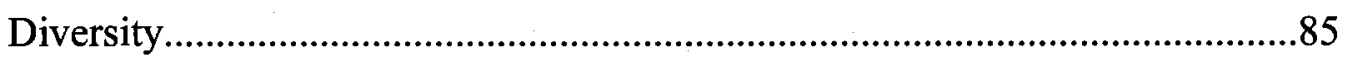

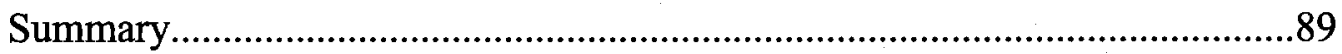

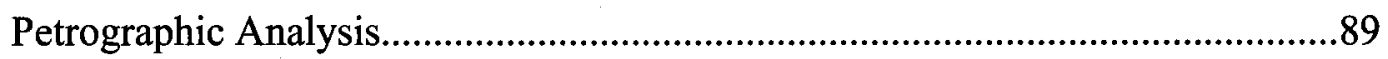

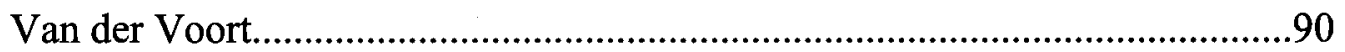

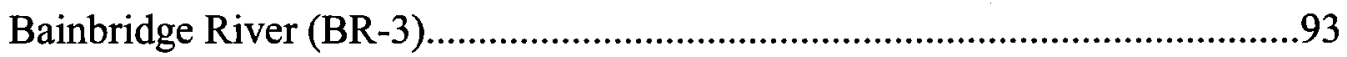

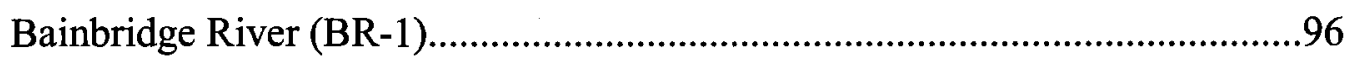

Carrot River (DH-1) ...................................................................................100

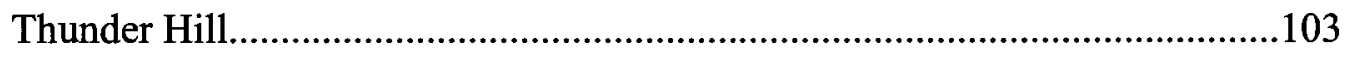

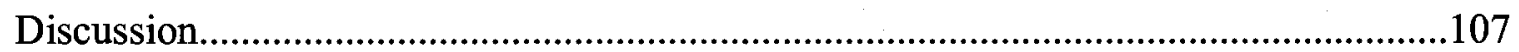

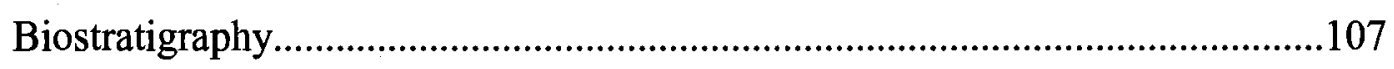

Taphonomic Interpretations..............................................................................118

Taphonomic Overprint at the Van der Voort Locality.....................................118

The Comparative Taphonomic Census.........................................................122

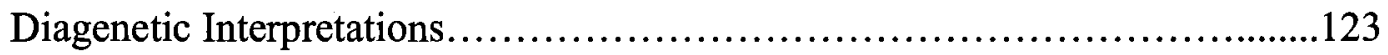

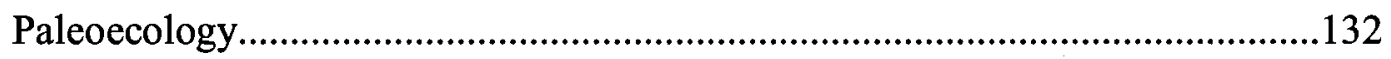

Vertebrate Faunal Distribution in the Western Interior Seaway.......................132

Paleoecological Interpretations.......................................140

Paleoenvironmental Interpretations......................................................................

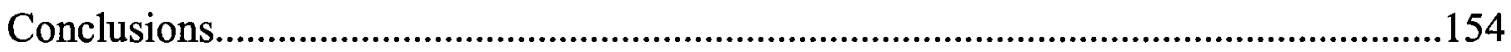

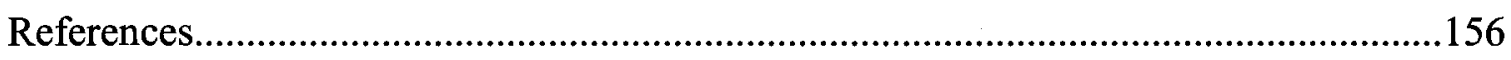

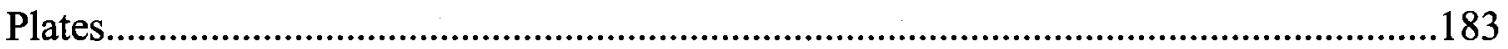

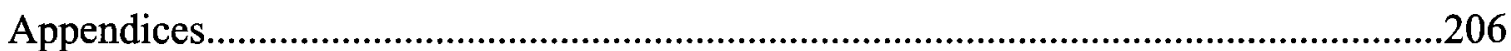




\section{LIST OF FIGURES}

Figure 1. Schematic diagram of a representative cross-section through the Western Interior Seaway (WIS) (modified after Decelles and Giles, 1996). Sediments deposited within the Manitoba Escarpment are located approximately within the area designated by "MB Escpt"

Figure 2. Paleogeographic maps showing the extent of epeiric sea coverage during A) the Late Late Albian and B) the Late Early Turonian (modified from Williams and

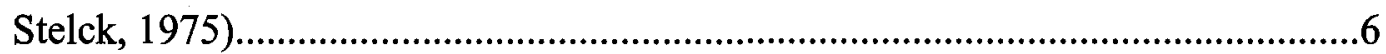

Figure 3. Global transgressive-regressive cycles and transgressive-regressive cycles in the northwest Alberta portion of the Western Cretaceous Sedimentary Basin during the Cretaceous (Aptian to Santonian) and radiometric ages at the stage boundaries. Modified after Kauffman (1977b), Obradovich (1993) and Mans (2007)

Figure 4. Map of the Manitoba Escarpment, modified after McNeil and Caldwell (1981) and Schröder-Adams et al. (2001). The major uplands of the escarpment include (1) the Pasquia Hills, (2) the Porcupine Hills, (3) Duck Mountain, (4) Riding Mountain, and (5) Pembina Mountain. Field localities pertinent to this study are the Carrot River (CR), Bainbridge River (BR), Little Woody River (LW), Thunder Hill (TH), and Van der Voort Farm (VF) localities .11

Figure 5. Regional stratigraphic nomenclature of selected early-Late Cretaceous strata of the Canadian Western Interior Basin and correlative rock units in the northern United States. Abbreviations are as follows: S. Cr. Sh. Mbr., Shell Creek Shale Member; Pool Cr. Mbr, Pool Creek Member. 
Figure 6. Generalized outline of the Fish Scales Formation (sensu Bloch et al., 1993) and its correlatives in Canada, including the "fish scale marker beds" of the Manitoba Escarpment described by McNeil and Caldwell (1981). Modified from Leckie et al., 1994; Jowett et al., 2007. .16

Figure 7. The Van der Voort Farm locality, near Riding Mountain, Manitoba, visited during the 2006 field season. (A) A view of the site from the southeast, with the north $(\mathrm{N})$ and south (S) banks labeled (Photo by author). (B) A view of the site looking east-southeast across the site from the north $(\mathrm{N})$ bank. The dugout pond (DO) is visible below, with Dr. Stephen L. Cumbaa (SLC) and the author (AJP) hard at work above (Photo courtesy of Dr. Charles Underwood). .25

Figure 8. Comparison of an unnamed caturid specimen (CMNFV 17462) described from Turonian strata near Lac des Bois, Northwest Territories (Cumbaa and Murray, in press) with material recovered from the Van der Voort locality, Manitoba. A Post-cranial section of articulated specimen CMNFV 17462. B and D - present magnified views of areas of CMN 17462FV (B - vertebrae, D - scales) relevant for comparison with C (partial vertebrae - MM V-2958, left; MM V-2957, right) and E (MM V-2963, top - lateral line scale; MM V-2962, bottom - non-descript scale) respectively. CMN - Canadian Museum of Nature; MM - Manitoba Museum. .51

Figure 9. Comparison between the Van der Voort (VDV) and Bainbridge River (BR-3) samples of the distribution of plate, elongate, and compact-shaped clasts. .79 
Figure 10. Comparison between the Van der Voort (VDV) and Bainbridge River (BR-3) samples of the distribution of clasts within discrete size increments

Figure 11. Comparison between the Van der Voort (VDV) and Bainbridge River (BR-3) samples of the distribution of clasts within described abrasion states. Total number of clasts included varies here from other tests due to the exclusion of coprolites

Figure 12. Representative examples of the abrasion stages used to score vertebratederived elements from the Van der Voort and Bainbridge River (BR-3) localities for the taphonomic census. (A) Stage 0 - Very Angular; (B) Stage 1 - Subangular; (C) Stage 2 - Subrounded; (D) Stage 3 - Rounded; Stage 4 - Very rounded. .84

Figure 13. Comparison of the types of clasts recovered from the Van der Voort (VDV) and Bainbridge River (BR-3) samples examined for the comparative taphonomic census. $\mathrm{N}_{\mathrm{VDV}}=1770 ; \mathrm{N}_{\mathrm{BR}-3}=1805$. . .86

Figure 14. Comparison of the types of clasts recovered from the Van der Voort (VDV) and Bainbridge River (BR-3) samples examined for the comparative taphonomic census, after division of the anatomically unidentified 'Indet. bones and frag.s' in Figure 13 along suspected osteichthyan and "reptilian" affinities. $\mathrm{N}_{\mathrm{VDV}}=1770$; $\mathrm{N}_{\mathrm{BR}-3}=1805$. .87

Figure 15. Representative SEM images of thin-section material from the Van der Voort Farm. Low contrast (A) and higher contrast (B) general views of calcite-cemented wackestone to packstone with pervasive inoceramid-derived prismatic calcite. In 
(A) and (B), pyrite (Py) can be seen as small white flecks, while vertebrate bone (Ap) appears much brighter in (B). In (B), prismatic calcite can de distinguished as slightly darker in colored than the lighter sparry calcite cement surrounding it.. 92

Figure 16. SEM images of thin section material from the Van der Voort Farm. (A)

Framboidal (F) and euhedral (E) pyrite under high magnification. (B) Higher magnification high contrast view, highlighting the difference between sparry calcite cement $(\mathrm{C})$ and inoceramid-derived prismatic calcite $(\mathrm{P})$. Pyrite $(\mathrm{Py})$ is visible as small, white flecks, and the darker, rough-textured area in the centre of the photograph is argillaceous material $(\mathrm{Ag})$. Also visible is the characteristic hourglass form of a fish vertebra (V).

Figure 17. Representative SEM image of thin section material from the Bainbridge River (BR-3). General view of calcite-cemented (C) bone-biophospharenite with a coarse grainstone to rudstone texture. Apatitic bone and tooth fragments visible here include a fish vertebra (V) and fish teeth (T). Also visible is some pyrite as small white flecks (Py). .95

Figure 18. SEM images of thin section material from the Bainbridge River (BR-3). High contrast (A) and lower contrast (B) general views of calcite-cemented (C) bone biophospharenite with a coarse grainstone to rudstone texture. Pyrite (Py) is visible as white flecks and identifiable vertebrate fragments include teeth $(\mathrm{T})$. Some calcite, consistent with inoceramid-derived prismatic calcite $(\mathrm{P})$, is also visible in (A), being slightly darker than the calcite surrounding it. 
Figure 19. SEM images of thin section material from the Bainbridge River (BR-3). (A)

High contrast image highlighting a region of 'articulated' inoceramid prisms (P). Calcite-cemented (C) and vertebrate bioclasts (Ap) are also visible. (B) Clusters of pyrite (visible as small white flecks) occurring around and within a coprolite (Cp) surrounded by calcite cement (C) .98

Figure 20. Representative SEM image of thin section material from the Bainbridge River (BR-1). General view of calcite-cemented (C) bone-biophospharenite with a grainstone texture. Apatitic bone and tooth fragments (Ap) are abundant, and include some partially pyritized elements (Py) 99

Figure 21. SEM images of thin section material from the Bainbridge River (BR-1). (A, B) Increasingly magnified view of pyrite crystal growth within a fish tooth (this tooth is also visible in the centre of Fig. 20)

Figure 22. Representative SEM images of thin section material from the Carrot River. (A, B) General views of calcite-cemented (C) grainstone with apatitic bone and tooth fragments (Ap), common partially pyritized bone fragments (Py) and localized micrite cement $(\mathrm{M}$, in $\mathrm{B})$ 102

Figure 23. Representative SEM images of thin section material from the Thunder Hill.

(A, B) Phosphatic bioclasts are tightly packed within a reduced calcite matrix; pyritized bone and tooth fragments are abundant. (LC) shows linear grain contacts, (BG) shows broken grains. 104

Figure 24. SEM images of thin section material from the Thunder Hill. (A) Pyrite occurs as both framboids (F) and euhedra (E). (B) Pyrite (Py) completely filling the internal pore space of a fish tooth $(\mathrm{T})$, surrounded by calcite cement (C). 105 
Figure 25. Index map showing McNeil and Caldwell (1981) outcrop locations 65 to 82, along the Vermilion and Wilson Rivers, north of Riding Mountain Provincial Park, Manitoba. LW - Little Woody River; VF - Van der Voort Farm. Modified from McNeil and Caldwell (1981) and Schröder-Adams et al. (2001). 108

Figure 26. An example of an unprepared sample of Van der Voort Farm inoceramite that was particularly rich in disarticulated oyster valves, identified as Ostrea dunveganensis Warren 1930. Examples of preserved valves are indicated by arrows.

Figure 27. Index map showing McNeil and Caldwell (1981) outcrop locations 29 to 48; of note here are outcrop locations 36 to 45 along the Little Woody River, north of the Porcupine Hills, Manitoba. LW - Little Woody River; VF - Van der Voort Farm. Modified from McNeil and Caldwell (1981) and Schröder-Adams et al. (2001)

Figure 28. Index map showing McNeil and Caldwell borehole locations and lines of subsurface cross-sections. Note the proximity of section C-C' to the Little Woody River (LW) locality, and the proximity of section G-G' to the Van der Voort Farm (VF) locality. Modified from McNeil and Caldwell (1981). 115

Figure 29. Summary of diagenetic trends, increasing in degree or abundance from left to right as observed petrographically in thin sectioned samples from the Van der Voort (VDV), Bainbridge River 3 (BR-3), Bainbridge River 1 (BR-1), Carrot River (CR), and Thunder Hill (TH) localities 130 
Fig. 30. Comparison of representative thin sections (50X magnification) of five bioclastic accumulations from the collected from the Manitoba Escarpment. (A) Van der Voort locality: note abundant inoceramid-derived calcite prisms, sparse phosphatic elements and point contacts between grains. (B) Bainbridge River (BR-3) locality: note large "floating" phosphatic grains. (C) Bainbridge River (BR-1) locality: note increasingly linear contact between grains and increased compaction. (D) Carrot River locality: note linear grain contacts, greater compaction, and frequent splintered grains. (E) Thunder Hill locality: note rounded and abraded phosphatic elements, and high degree of pyritization......131 


\section{LIST OF TABLES}

Table 1. Pertinent outcrop locations along the Manitoba Escarpment............................23

Table 2. Abrasion assessment scheme, based on Fiorillo (1988) and Cook (1995).........29

Table 3. Statistical comparison via Chi-square tests of taphonomic indicators scored for the clasts recovered from the Van der Voort (VDV) and Bainbridge River (BR-3) samples used for the comparative taphonomic census. The column "p(same)" indicates the probability that the distribution curves from the two samples are the same. *The number of clasts used for the abrasion distributions varies from the other distribution values due to the exclusion of coprolites .78

Table 4. Percent differences between the numbers of clasts counted for and within each taphonomic variable. Positive differences represent a comparative surplus for the Van der Voort (VDV) sample; negative differences represent a comparative surplus for the Bainbridge River (BR-3) sample. Note that $\mathrm{N}_{\mathrm{VDV}}=1770$ and $\mathrm{N}_{\mathrm{BR}}$ ${ }_{3}=1805$ for Shape and Size Increments, while $\mathrm{N}_{\mathrm{VDV}}=1707$ and $\mathrm{N}_{\mathrm{BR}-3}=1610$ for Abrasion State due to the exclusion of coprolites. . .80

Table 5. Statistical comparison via Chi-square tests of the distribution of the clasts recovered from the Van der Voort (VDV) and Bainbridge River (BR-3) samples used for the comparative taphonomic census. The column " $p$ (same)" indicates the probability that the distribution curves from the two samples are the same. . .88

Table 6. Summary of Petrographic Observations (based on point count analysis and SEM observations) 


\section{LIST OF APPENDICES}

Appendix I. Van der Voort Locality Calcarenite Sample Measurements........................207

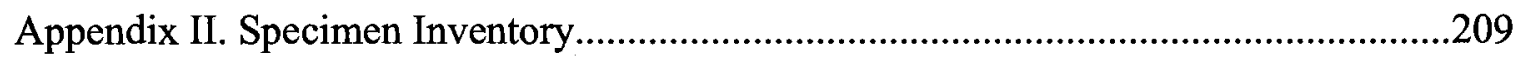

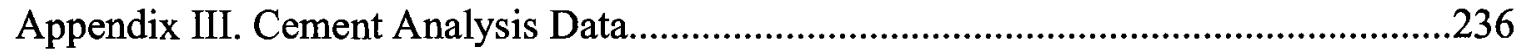




\section{INTRODUCTION}

Recent geological and paleontological research in Canada on Late Cretaceous strata deposited within the Western Canada Sedimentary Basin (WCSB) has resulted in the identification of numerous vertebrate fossil-rich horizons of Cenomanian age (e.g. Leckie et al., 1992; Cumbaa and Tokaryk, 1999; Cook, 2007). These horizons contain extraordinary concentrations of vertebrate skeletal material and occur discontinuously in outcrop and in subsurface cores across the WCSB stretching from eastern British Columbia to central Manitoba (e.g. Mossop and Shetson, 1994; Bloch et al., 1993; Schröder-Adams et al., 1999).

Bioclastic horizons are of interest to sedimentologists, stratigraphers, and paleontologists alike. Their occurence might be related to changes in relative sea-level, representing times of reduced clastic input and seafloor winnowing (Sageman, 1996). If these lags become regionally extensive and can be detected in wireline logs these beds become important markers for stratigraphic correlation. Their composition provides insight on the vertebrate fauna and its paleoecology, and their taphonomic signature points towards depositional mechanisms and diagenetic histories.

Although horizons with concentrated vertebrate debris have been observed across the Cretaceous WCSB, the best developed bonebeds occur along the eastern margin of the basin due to minimal clastic dilution. One region in which these horizons are abundantly observed in outcrop is along the Manitoba Escarpment, a southeast-northwest trending series of uplands spanning southwestern Manitoba and east-central Saskatchewan. Previous work on Cenomanian-aged bonebeds along the eastern margin concentrated on those found near the Pasquia Hills of Saskatchewan, along the 
Bainbridge and Carrot Rivers where bonebeds delivered extraordinarily rich vertebrate assemblages, including the earliest diverse avifauna described from North America. (Cumbaa and Tokaryk, 1999; Schröder-Adams et al., 1999; Cumbaa and Bryant, 2001; Schröder-Adams et al., 2001; Cumbaa et al., 2006). This study focuses on a locality near the town of Riding Mountain, Manitoba, where in July of 2006 vertebrate fossil-rich calcarenites were collected. These calcarenites vary from previously described Cenomanian vertebrate horizons within the Western Interior Sea in terms of the composition of the marine vertebrate fauna and inferred diagenetic history, as well as in terms of stratigraphic position. Comparison with the faunas known from other Cenomanian-aged localities in the North American Western Interior Basin add to our understanding of the depositional and diagenetic history of these deposits. Finally, the combined information gleaned from the above surveys and analyses allows us to gain insight into the paleoecological and paleoenvironmental conditions that predominated within this ancient seaway during Cenomanian time. A better understanding of the cause and frequency of these erosional remnants may contribute to sea-level studies and regional stratigraphic correlations. 


\section{GEOLOGICAL SETTING}

\section{The Western Canadian Sedimentary Basin}

\section{Tectonic Setting and Basin Architecture}

Between the Middle Jurassic and Eocene epochs, the Western Interior of the North American continent was the locus for the development of a complex foreland basin, developed in tandem with the simultaneously rising Cordillera (Leckie and Smith, 1992; Kauffman and Caldwell, 1993). Northwestward and westward movement of the North American Plate through these times resulted in the accretion of a significant number of allochthonous terranes carried on "Pacific" plates which were being obducted on the continent's western margin; the compressional imbrication and thickening of these accreted plates, along with pre-existing deposits along the western continental margin and the products of upper-plate, subduction-related magmatism, resulted in the uplift of the Cordillera (Monger, 1993). Tectonic loading occurring on the western margin resulted in a coeval downwarping of the stable North American craton to the east of the developing Cordillera, and thus an extensive foreland basin was created (Kauffman and Caldwell, 1993). The Western Canadian Sedimentary Basin was a north-south trending trough, oriented parallel to the eastern margin of the Cordillera, being deepest in the western foredeep adjacent to the mountains and shallowing towards the backbulge (Kauffman and Caldwell, 1993) (Fig. 1). This eastward shallowing from the foredeep was, however, not uniform due to the presence of the forebulge; which is defined as "a region of potential flexural uplift along the cratonic side of the foredeep" (Decelles and Giles, 1996). 


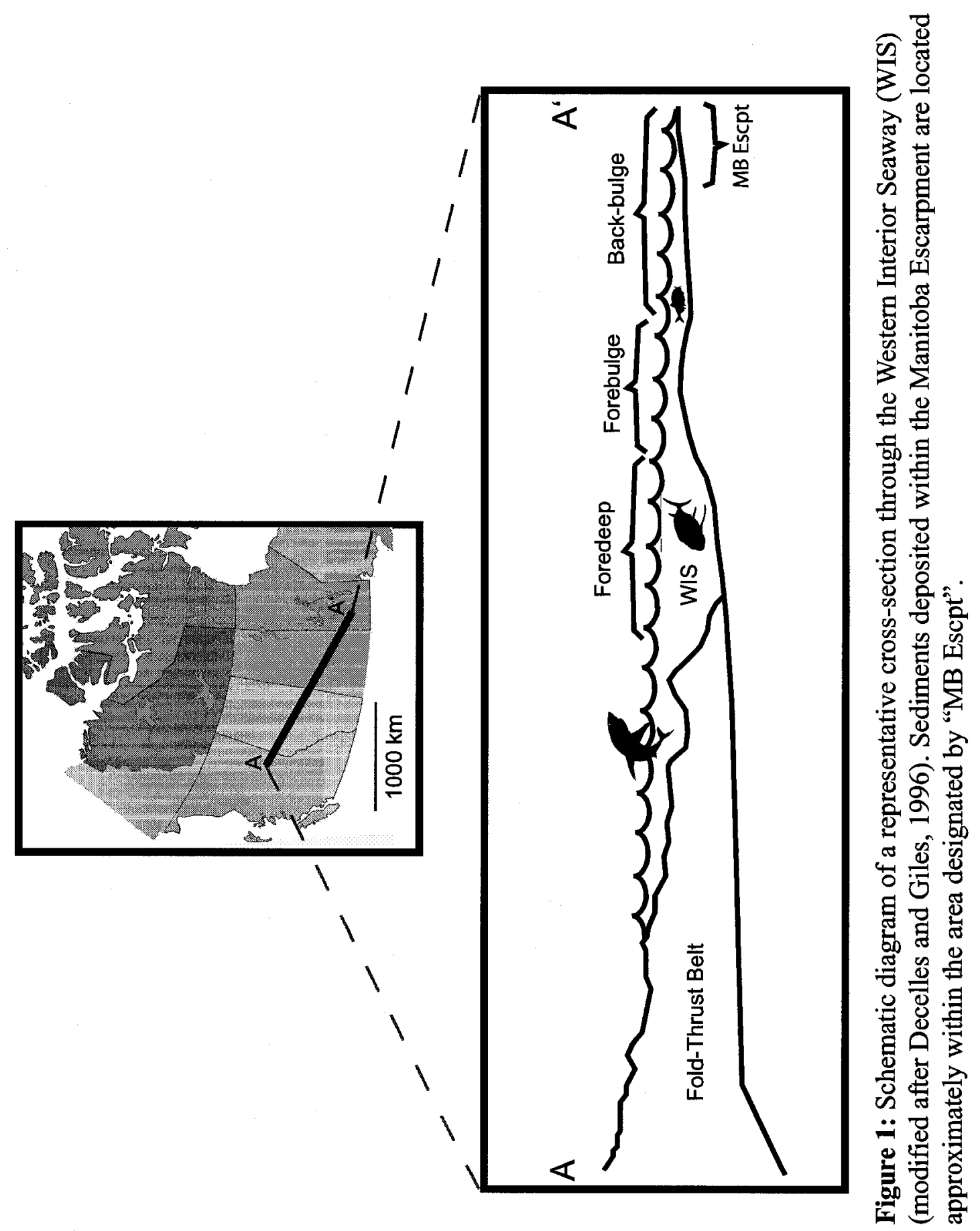




\section{Patterns of Sedimentation}

As the Cordillera continued to rise, the Western Canadian Sedimentary Basin became the prime repository for sediments eroding off the newly formed mountains, resulting in a large, roughly wedge-shaped package of terrestrial and marine sediments of Mesozoic and Cenozoic age overlying Paleozoic deposits laid down on the formerly passive western margin of North America (Dixon, 1993). The uplift of a discontinuous forebulge distal to the active tectonic front came to restrict the deposition of synorogenic sediments in the rapidly subsiding foredeep adjacent to the Cordillera, and variably contributed to the expanded sections seen there today (Donaldson et al., 1998; Plint, 2003; Tyagi et al, 2005; Plint and Wadsworth, 2006; Plint and Kreitner, 2007). In contrast, along the eastern margin of the basin, sediment input from the stable craton was relatively low, subsidence was slow and episodic, and the resulting deposits are thin, commonly unconformity-bound condensed sequences with a paucity of coarse-grained terrestrially-derived sediments (McNeil and Caldwell, 1981).

\section{The Late Cretaceous Western Interior Seaway}

\section{Sea-level History}

The combination of basin subsidence, tectonic uplift and periods of eustatic changes in sea level resulted in the variable flooding of the Western Interior Basin, and thus the coverage of large parts of the Interior of North America by an epicontinental sea known as the Late Cretaceous Western Interior Seaway (Fig. 2). During the Early Cretaceous, inundation of the Interior was only in the northern part of North America, connected to the Boreal Sea. By the early Late Albian sea-level rise resulted in the Joli Fou Seaway 


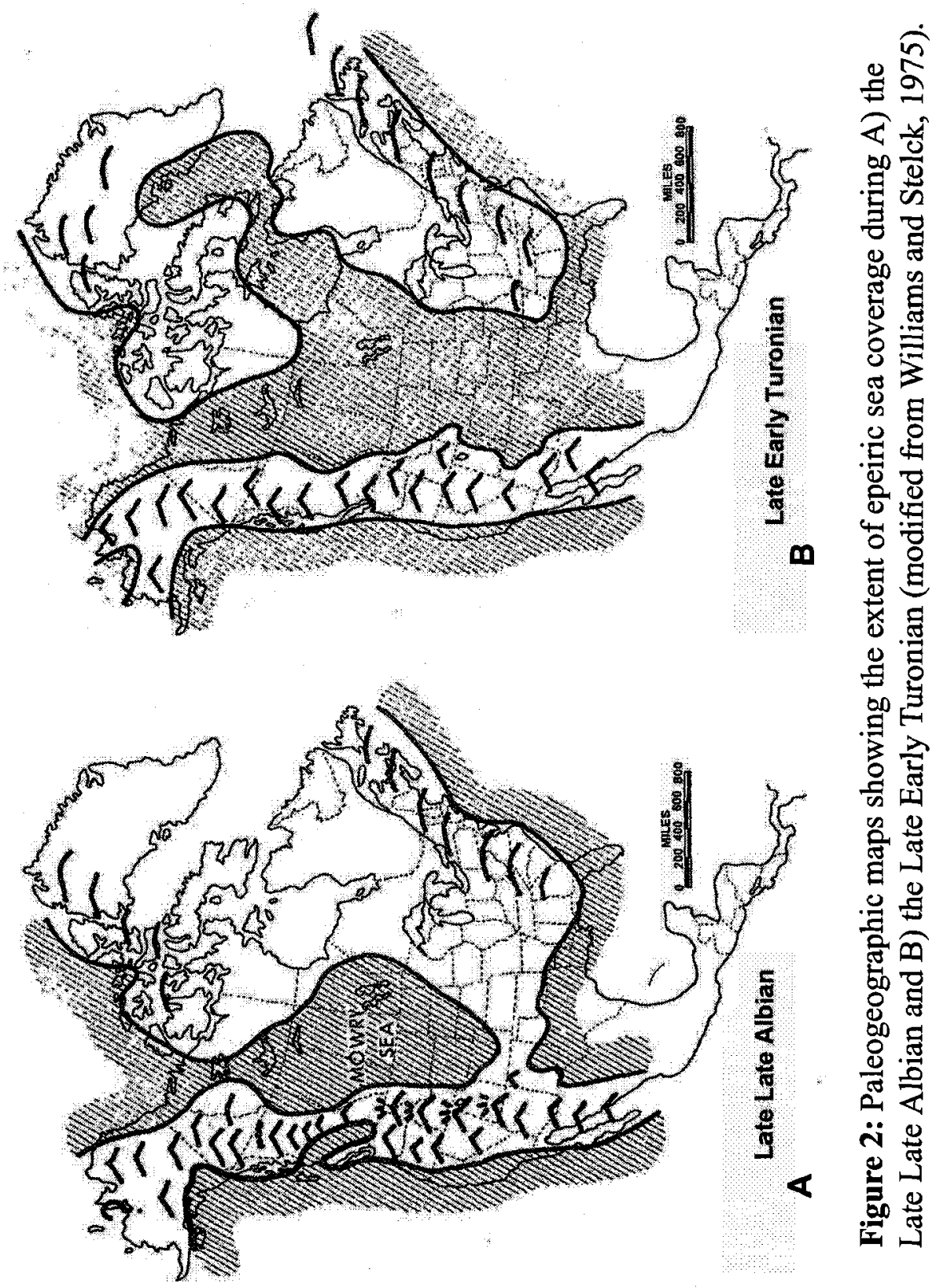


connecting the Boreal Sea to the north with the proto-Gulf of Mexico (the Tethyan Sea) to the south (Stelck and Koke, 1987). This initial connection was relatively short-lived, terminating in the Late Albian with the formation of the restricted Mowry Sea (Fig. 2a). Renewed transgression during the Greenhorn Marine Cycle in the latest Albian/earliest Cenomanian (Hattin, 1962; 1964; Kauffman, 1977a) culminated with peak transgression in the early Turonian (Figs. $2 \mathrm{~b}, 3$ ). A near-peak flooding shoreline, known from the latest Cenomanian of South Dakota, indicates that the Greenhorn Sea may have flooded as much as approximately $300 \mathrm{~m}$ above current sea level (McDonough and Cross, 1991). The Greenhorn Cycle, in addition to being the greatest of the transgressive-regressive cycles in the basin, was dynamic, encompassing two to three third-order cycles recognized in the late Albian, one third-order cycle in the lower Cenomanian, another third-order cycle in the middle Cenomanian, and two third-order cycles (overprinted by four to five fourth-order cycles) in the late Cenomanian (summarized in Kauffman and Caldwell, 1993). Indeed, recent work in northern Alberta (Plint and Kreitner, 2007) and southwestern Utah (Laurin and Sageman, 2007) in upper Cenomanian and lower Turonian strata have revealed a dozen or more transgressive-regressive events covering that time span, where sea-level changed by up to $10 \mathrm{~m}$ on a time scale varying from 9-74 thousand years (kyr) in Alberta, and 20-40 kyr (for short-term sequences), 65-160 kyr (for medium-term sequences), up to $800 \mathrm{kyr}$ (for long-term sequences) in Utah.

After the Greenhorn Cycle (Fig. 3), sea-level continued to rise and fall throughout the Niobrara (Kauffman, 1969, 1977a), Claggett and Bearpaw (Gill and Cobban, 1973; Kauffman, 1977b) and Fox Hills (Waage, 1978; Kauffman and Caldwell, 1993) marine cycles (and the numerous smaller-order cycles within them), providing a continuous, 


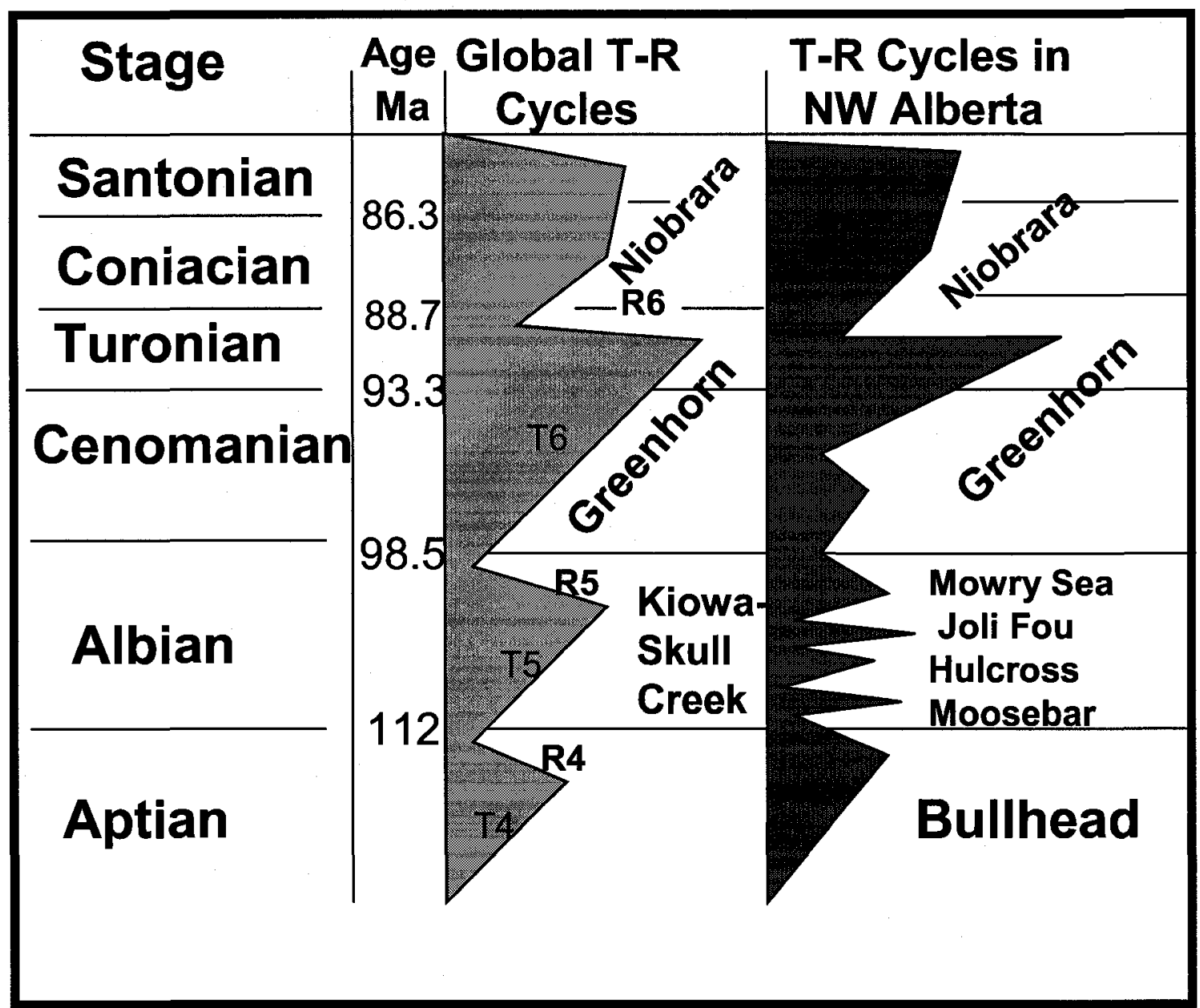

Figure 3: Global transgressive-regressive cycles and transgressive-regressive cycles in the northwest Alberta portion of the Western Cretaceous Sedimentary Basin during the Cretaceous (Aptian to Santonian) and radiometric ages at the stage boundaries. Modified after Kauffman (1977b), Obradovich (1993) and Mans (2007). 
though variable, epeiric connection between the Boreal and Tethyan seas until middle Maastrichtian time (spanning over 32 million years). Followed by rapid draining of the basin, the seaway ultimately retreated from the Western Interior Basin, with no marine sediments begin preserved within the Western Interior after late Palaeocene time (Hoganson and Cvancara, 1989; 1991; Cvancara and Hoganson, 1993; Hoganson and Murphy, 2002).

\section{Paleoenvironmental Conditions}

Relatively long periods of episodic watermass density stratification occurred throughout the history of the basin (during the Kiowa-Skull Creek, Greenhorn, Niobrara and Claggett cycles) due to sluggish oceanic circulation and the interaction of northern and southern water masses (Kauffman, 1988; Hay, 1989; Hay et al., 1993). Poor circulation and abundant terrestrial runoff are thought to have contributed to salinity stratification in the blind-ended seas of the late Albian, whereas thermal stratification is thought to have played a larger role in the later seas (Late Cenomanian to Santonian) formed by the mixing of cool-temperate, somewhat brackish Boreal-derived waters and warm-temperate to sub-tropical, normal saline Tethys-derived waters (e.g. Kauffman, 1988; Hay, 1989; Caldwell et al., 1993; Glancy et al., 1993; Hay et al., 1993; Kyser et al., 1993; Schröder-Adams et al., 1996). These conditions, combined with possible northward incursions of an expanded oxygen-minimum zone into the bottom waters of the Western Interior Sea from the Tethys Sea during peak-transgression periods, all contributed to the density stratification, reduced downward mixing of oxygenated surface waters, reduced benthic oxygenation and organic-carbon accumulation during the Late Cretaceous (e.g. Kauffman, 1988; Hay, 1989; Caldwell et al., 1993; Glancy et al., 1993; Hay et al., 1993; 
Kyser et al., 1993; Schröder-Adams et al., 1996; Leckie et al., 1998; White and Arthur, 2006). These dysoxic to anoxic mid- to bottom-water environments, combined with brackish waters originating from high terrestrial runoff and cool, dense northern waters further limited the biota, at times to a low diversity assemblage lacking many groups typical of open marine conditions altogether (Kauffman and Caldwell, 1993). However, despite these relatively stressed living conditions, particularly for benthic organisms, the Western Interior Seaway still supported a relatively diverse assemblage of vertebrates through time (e.g. Nicholls and Russell, 1990; Russell, 1988; 1993; Cumbaa et al., 2006; Shimada et al., 2006; Cook, 2007).

\section{The Manitoba Escarpment}

The Manitoba Escarpment is a southeast-northwest trending series of uplands extending from south-central Manitoba/north-central North Dakota to east-central Saskatchewan (Fig. 4). The Escarpment comprises (from north to south) the Pasquia Hills, the Porcupine Hills, Duck Mountain, Riding Mountain, and Pembina Mountain, extending a distance of approximately $675 \mathrm{~km}$. In Canada, the Manitoba Escarpment represents the eastern erosional margin of both the Western Canadian Sedimentary Basin and the Western Interior Seaway; at times of sea-level highstand the eastern coastline of the Western Interior Seaway would have been further east (Nielsen, 2003). Cretaceous sequences are thin in comparison to correlative strata in the foredeep of Alberta and British Columbia. Frequent unconformities are sedimentologically difficult to detect due to the lack of pebble beds, but indicated by biostratigraphic analysis (McNeil and Caldwell, 1981). These strata were deposited on the stable eastern platform referred to as the backbulge (using the nomenclature of Decelles and Giles, 1996) (again, see Fig. 1) in 


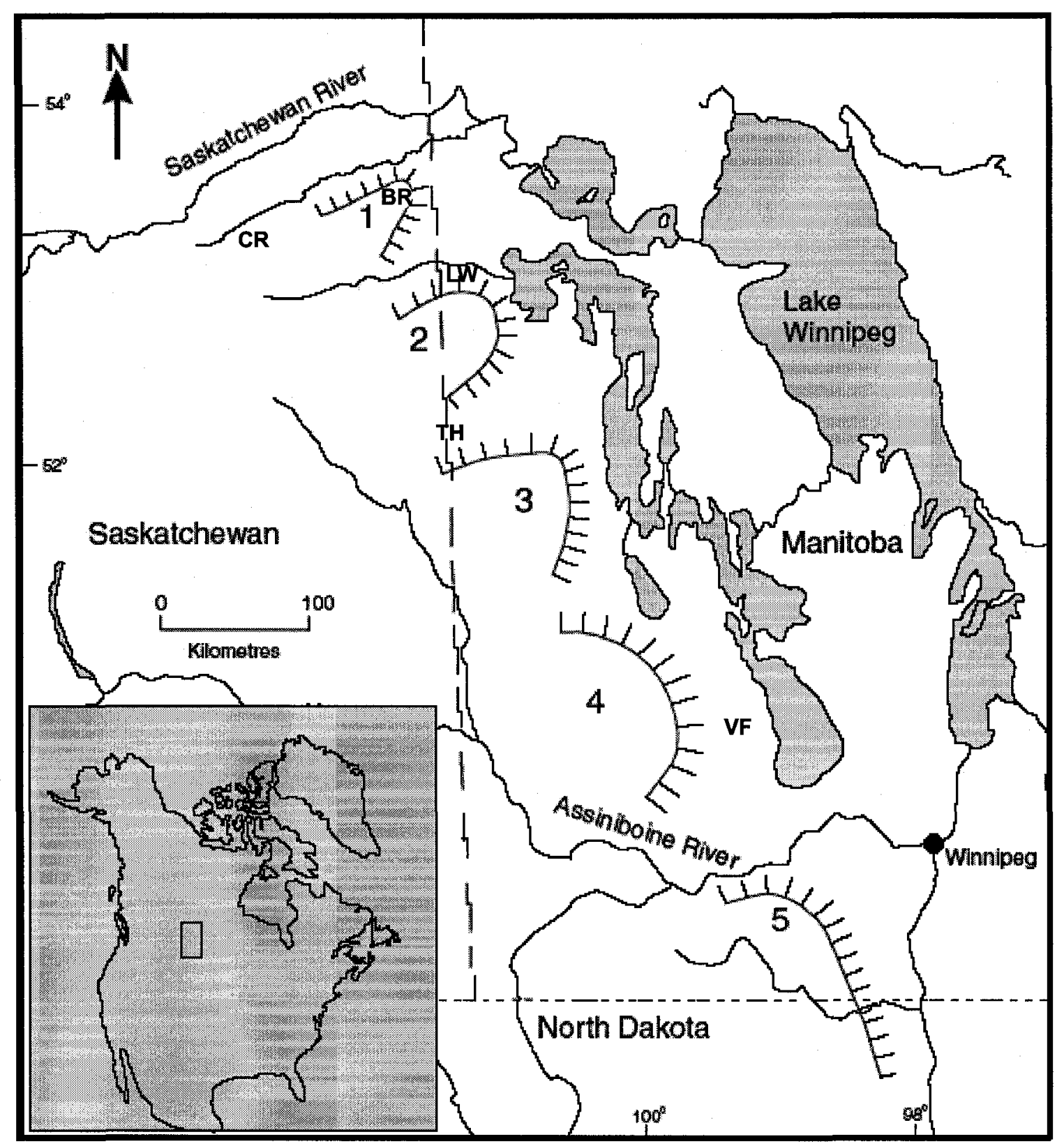

Figure 4: Map of the Manitoba Escarpment, modified from McNeil and Caldwell (1981) and Schröder-Adams et al. (2001). The major uplands of the escarpment include (1) the Pasquia Hills, (2) the Porcupine Hills, (3) Duck Mountain, (4) Riding Mountain, and (5) Pembina Mountain. Field localities pertinent to this study are the Carrot River (CR), Bainbridge River (BR), Little Woody River (LW), Thunder Hill (TH), and Van der Voort Farm (VF) localities. 
waters that rarely exceeded $100 \mathrm{~m}$ in depth even at maximum transgression (Kauffman, 1969; Hattin, 1975). In this region both sedimentation and subsidence rates were low, and the resulting strata are condensed and lack substantial coarse-grained terrigenous siliciclastic material compared to the coarser expanded sections resulting from increased accommodation space in the rapidly subsiding foredeep (McNeil and Caldwell, 1981; Tyagi et al, 2005).

The current classification of the strata of the Manitoba Escarpment was established by McNeil and Caldwell (1981) and can be characterized broadly as condensed strata composed primarily of fine-grained terrigenous clastic and pelagic carbonate sediments (McNeil and Caldwell, 1981). Differing somewhat from this generalization are the horizons most pertinent to this study, which are found within the Belle Fourche Member of the Ashville Formation (Fig. 5).

Stratigraphic Relationships of The Belle Fourche Member

After examining the Belle Fourche Shale at its type locality near Belle Fourche, South Dakota (Collier, 1920; 1922), and correlating it in the subsurface northwards to the Manitoba Escarpment, McNeil and Caldwell (1981) designated the upper carbonaceous shales of the Ashville Formation as the Belle Fourche Member. Stratigraphically, the member unconformably overlies the Westgate Member of the Ashville Formation and is overlain by the Keld Member of the Favel Formation (Fig. 5). The contact between the upper Belle Fourche Member and the Keld Member is gradational in the Riding 


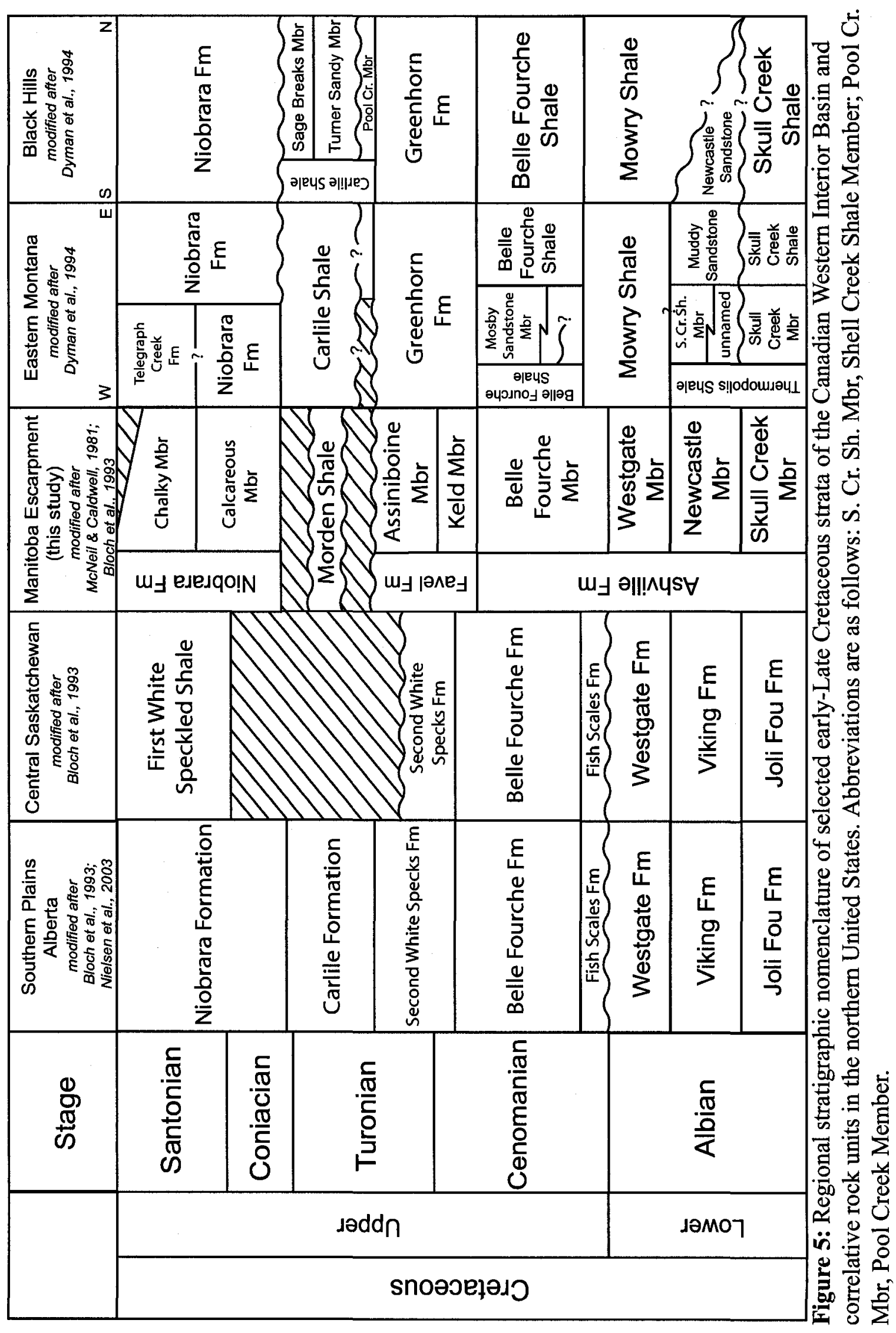


Mountain and Duck Mountain areas; however, it becomes unconformable in the northwest; a fact recognized due to the progressive disappearance of abundant, readily correlated bentonite beds found throughout the Belle Fourche Member (McNeil and Caldwell, 1981). The Belle Fourche Member is correlative with the Belle Fourche Formation in the subsurface of central Saskatchewan and the central plains of Alberta (Bloch et al. 1993) and the Belle Fourche Shale in North and South Dakota (McNeil and Caldwell, 1981). The upper part of the Belle Fourche Member likely correlates with the lower Lincoln Limestone Member of the Greenhorn Formation in Colorado/Kansas and adjoining areas (Fig. 5 and McNeil and Caldwell, 1981).

Deposited during the Greenhorn transgression (Fig. 3), the Belle Fourche Member along the eastern margin is composed predominantly of uniform, greyish-black or black, carbonaceous, noncalcareous shale interbedded with numerous bentonite beds and thin beds or lenses of siltstone, fine-grained sandstone or calcarenite (McNeil and Caldwell, 1981). Additionally, it carries a distinctive sequence of stratigraphic marker beds of regional significance, described below.

\section{Lower Belle Fourche Member of the Ashville Formation}

Regional Correlation and Significance of the "Fish Scale Marker Beds": The stratigraphically lowest regional marker is what will here be referred to as the "fish scale marker beds". In the subsurface of central Saskatchewan and the central plains of Alberta, Bloch et al. (1993) described the Fish Scales Formation by including strata previously referred to as Base of Fish Scales, Fish Scale Marker Bed, Fish Scale Sandstone and Fish Scale zone. They also recommended that the correlative and distinct "fish remains zone" of the Shaftesbury Formation in the northwestern Alberta plains (Gleddie, 1954; Wall, 
1967), where the term "fish scales bearing" was first used to describe shales in the WCSB (Selwyn, 1877), be assigned member status within the Shaftesbury Formation. In this study I retain the term "fish scale marker beds" to correlate to McNeil and Caldwell's (1981) comprehensive study of the stratigraphy along the Manitoba Escarpment.

The significance of the Fish Scales Formation and its correlatives lies in its basinwide recognition in subsurface well log data (Fig. 6). The contact between the underlying Westgate Formation and the Fish Scales Formation (which is commonly referred to as the "Base of Fish Scales") is expressed in wireline logs primarily as a sharp increase in gamma-ray and resistivity response, and it is commonly used as a marker horizon for the Early and Late Cretaceous (i.e. Albian-Cenomanian) boundary (Leckie et al., 1992; Bloch, et al., 1993). Though barren of foraminifera (Leckie et al., 1992; Bloch et al., 1993), dinoflagellate assemblages within these strata (Singh, 1983; Leckie et al., 1992, 1999; Schröder-Adams et al., 1996) support an early Cenomanian age. The transition to the overlying Belle Fourche Formation in central Saskatchewan and the central plains of Alberta is gradational and is characterized by the appearance of the Verneuilinoides perplexus Zone of middle Cenomanian affinity (Bloch et al., 1993, Schröder-Adams et al., 1996, Tyagi et al., 2007).

Lithology and Biostratigraphy: In the Manitoba Escarpment, the base of the fish scale marker beds were recognized by McNeil and Caldwell (1981) to be coincident with the base of the Belle Fourche Member, and identified in outcrop by the occurrence of abundant fish framents as well as silty lenses and laminae within the lowermost six to ten metres of the unit; fossiliferous beds or lenses composed largely of fish debris occur in 


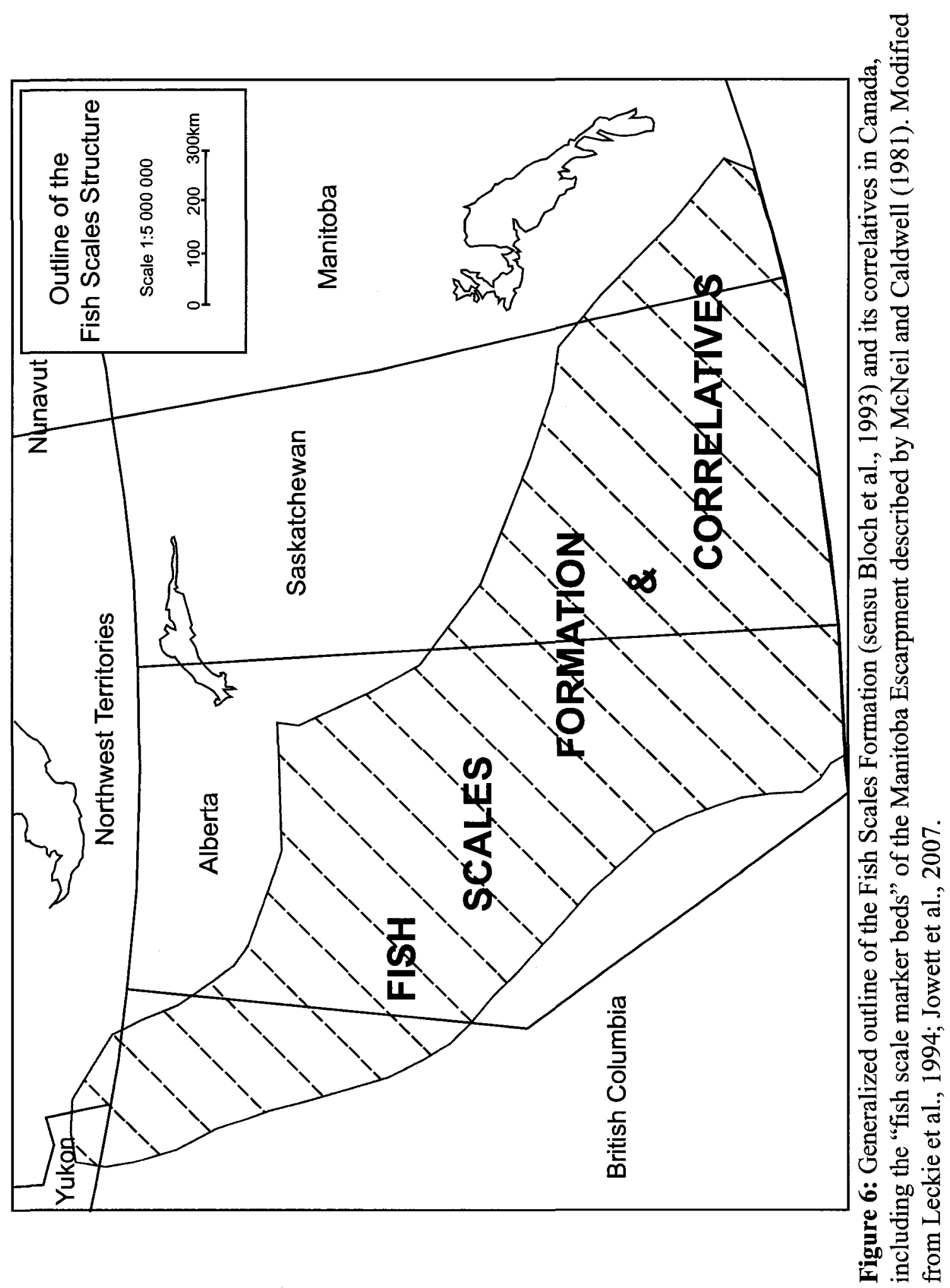


the lowest five metres. The contact of the Belle Fourche Member and the fish scale marker beds with the underlying Westgate Member of the Ashville Formation is typically sharp, while the upper boundary was assigned arbitrarily as the top of a distinctive, widespread, silty, calcarenitic unit (McNeil and Caldwell, 1981).

The lowest three metres of the fish-scale marker beds along the escarpment are not barren of foraminifera as in the western part of the basin, but instead reveal components of the Miliammina manitobensis Zone (McNeil and Caldwell, 1981). McNeil and Caldwell (1981) interpreted this as an indication that the lower portion of the Belle Fourche Member and the fish-scale marker beds within it are of latest Albian age in the Manitoba Escarpment and that the unit is diachronous across the basin, while other authors (e.g. Bloch et al., 1993) debate the possibility of reworking of late Albian foraminiferal assemblage into the early Cenomanian shales.

In comparison, further west in the basin the equivalent Fish Scales Formation is described as being composed primarily of well laminated claystones and mudstones generally less than $20 \mathrm{~m}$ thick (Bloch et al., 1993). In the central foothills of Alberta, equivalent strata occur with a thin (up to $3.5 \mathrm{~m}$ thick) sandstone capped with chert pebbles, while in central Saskatchewan it can be recognized by the occurrence of a thin $(<5 \mathrm{~cm})$ coarse sandstone or pebble layer overlain by organic-rich shale (Bloch et al., 1993; Schröder-Adams et al., 1996; Leckie et al., 2000; Ridgely and Gilboy, 2001; Ridgely et al., 2001; Tyagi et al., 2007). Though abundant disarticulated vertebrate skeletal material is disseminated throughout the unit, it is particularly concentrated in the coarse, basal, erosional layer (Leckie et al., 1992; Bloch et al., 1993). 
The vertebrate assemblage of the lower Cenomanian bioclastic conglomerate within the Shaftesbury Formation of the northwestern Alberta plains contains abundant teleost fish scales belonging predominantly to Osmeroides transversus. Remains of unidentified ichthyodectids and enchodontiforms have been noted, as well as vertebral centra attributed to ichthyosaurs (Leckie et al., 1992). Teleost vertebral centra (Leckie et al., 1992) and the remains of the earliest known North American paracanthopterygian fish, Xenyllion zonensis (Wilson and Murray, 1996) have also been described from this formation. Whether it is the small size of the preserved remains or their fragmentary nature that is to blame, relatively little work has been done on assessing the diversity of the vertebrate fauna of the Fish Scales Formation, and what little has been described has all come from Albertan exposures (Leckie et al., 1992; Wilson and Murray, 1996). An examination of the literature revealed no attempt to describe vertebrate remains from the correlative fish scale marker beds in the Manitoba Escarpment.

Depositional Environment of the Fish Scales Formation: In Alberta, the deposition of the Fish Scales Formation has been interpreted as the result of marine transgression and/or of deeper water current-winnowing, with the coarsest bioclastic-hash layer at the base of the formation representing a transgressive lag deposit (Leckie et al., 1992; Bloch et al., 1993). Overlying laminae within the formation are interpreted as representing a shallow water condensed section (Leckie et al., 1990; 1992). Sparse bioturbation, the complete absence of benthic microfossils, high accumulation of organic matter, the absence of benthic vertebrate fossils and the abundance of pelagic algal cysts have all contributed to the interpretation of deposition of the Fish Scales Formation under anoxic conditions (Leckie et al., 1990; 1992; Bloch et al., 1993; Schröder-Adams et al., 1996). 
The abundant vertebrate remains, on the other hand, are thought to have accumulated due to long-term, natural accumulation; their concentration in the Fish Scales Formation being interpreted as a taphonomic artifact of transgression rather than representing a mass death assemblage (Leckie et al., 1990; Wilson and Murray, 1996).

\section{Upper Belle Fourche Member}

Bio- and Chronostratigraphy: With the exception of the apparent latest Albian age of the lowest portions of the Belle Fourche Member of the Ashville Formation (and the uppermost portion, which is barren of foraminifera), the remainder of the member was further characterized as Middle Cenomanian in age by McNeil and Caldwell (1981) due to the presence of the Verneuilinoides perplexus Zone, as well as the presence of the paired Ostrea beloiti and "X" bentonite marker beds. O. beloiti is a biostratigraphic marker for the mid-Cenomanian (McNeil and Caldwell, 1974; Kauffman et al., 1993, Tyagi et al., 2007), and can be found in the upper part of the Belle Fourche Member in $10-15 \mathrm{~cm}$ thick lenses and beds of bioclastic calcarenite that are composed of $O$. beloiti valve fragments and calcitic prisms originating from disaggregated inoceramid bivalves (McNeil and Caldwell, 1981).

The $O$. beloiti beds in the upper Belle Fourche Member are found immediately below, above, or even straddling, a prominent bentonite bed, which compared favorably enough with the associations of $O$. beloiti and the "X" bentonites as originally observed in the Western United States. There these markers occur near the top of the Cenomanian Graneros Shale and its equivalents (e.g. Hattin, 1965; Cobban and Scott, 1972; Kauffman

et al., 1977; Cadrin et al., 1996; Fisher et al., 2001). ${ }^{40} \mathrm{Ar} /{ }^{39} \mathrm{Ar}$ dates of this bentonite delivered a variety of ages including 93.3 (Cadrin, 1992), $94.93 \pm 0.53 \mathrm{Ma}$ (Obradovich, 
1993 ) and $94.96 \pm 0.5 \mathrm{Ma}$ (Cobban et al., 2006). Together with the $O$. beloiti beds, the " $\mathrm{X}$ " bentonite provides a marker traceable for at least two-thirds the length of the Western Interior Basin (Tyagi et al., 2007), and its position in the stratigraphic framework of the Manitoba Escarpment by McNeil and Caldwell (1981) has been used in subsequent studies of these strata (e.g. Cumbaa and Bryant, 2001; Schröder-Adams et al., 2001; Cumbaa et al., 2006). Work is currently in progress to process select bentonites, including the " $\mathrm{X}$ " bentonite, from the Manitoba Escarpment for radiometric dates.

Bonebeds: Within this upper portion of the Belle Fourche Member, there are dense bioclastic and bonebed horizons, discovered primarily in outcrops along the Carrot and Bainbridge rivers in the Pasquia Hills (Cumbaa and Tokaryk, 1999). The most thoroughly described of these bonebed deposits is from the Bainbridge River locality, which occurs as discontinuous lenses $12-15 \mathrm{~cm}$ thick, composed of completely disarticulated, randomly oriented fossil remains of chondrichthyans, actinopterygians, marine reptiles and birds (Tokaryk et al., 1997; Cumbaa and Tokaryk, 1999; Cumbaa and Bryant, 2001; Schröder-Adams et al., 2001). The most abundant vertebrate remains within this bonebed are teeth (especially those of the teleost Enchodus), followed by vertebrae. The abundance of well-preserved, little-distorted avian post-cranial elements is unique (Tokaryk et al., 1997; Cumbaa et al., 2006). Other common components in bonebeds from the Bainbridge River include abundant, relatively undeformed coprolites thought to be of piscine origin and bentonite rip-up clasts rimmed with diagenticallyprecipitated calcite (Cumbaa and Tokaryk, 1999). With more than 40 vertebrate taxa identified, the fauna from the Carrot River and Bainbridge River deposits are interpreted 
as a diverse, shallow marine community (Cumbaa et al., 2006), including the earliest diverse avifauna known from North America (Tokaryk et al., 1997).

Stratigraphic Placement of Bonebeds: At the Bainbridge River locality, the primary (lensoid) bonebed is found almost immediately above the condensed, calcarenitic horizon marking the $O$. beloiti bed and approximately two metres below a 31 to $33 \mathrm{~cm}$ thick bentonitic horizon identified as the " $\mathrm{X}$ " bentonite (Cumbaa and Bryant, 2001). The Carrot River bonebed, meanwhile, was discovered in the upper third of a one metre thick section, and consisted of a pavé of small, contiguous to separated blocks capped by a 3-5 $\mathrm{cm}$ thick bentonite (Cumbaa et al., 2006). Samples below the bonebed contain the benthic foraminiferal Verneuilinoides perplexus Zone (while samples from above the bonebed were found to be barren of foraminifera) confirming a middle to late Cenomanian age for the deposit (McNeil and Caldwell, 1981; Schröder-Adams et a1., 2001). 


\section{MATERIALS \& METHODS}

This study is based on samples of bonebed/bioclastic horizons collected from six localities found along the length of the Manitoba Escarpment on both sides of the Manitoba/Saskatchewan border (see Table 1). Collection of samples from the Bainbridge and Carrot River localities has been ongoing since the joint field project of the Royal Saskatchewan Museum (RSM) and the Canadian Museum of Nature (CMN) began in the Pasquia Hills region of Saskatchewan in 1991 (Cumbaa and Tokaryk, 1999). Samples from these localities used in this study for comparative purposes were collected several years ago, prior to the author's involvement with this research. Samples used in this study from the Thunder Hill, Van der Voort Farm, and Little Woody River localities, meanwhile, were collected in July of 2006 by the author and other members of the 2006 field expedition. The Thunder Hill and Little Woody River localities, originally described by McNeil and Caldwell (1981), had previously been visited by field parties from the Canadian Museum of Nature (Cumbaa, pers. comm., 2006), and the newly discovered Van der Voort Farm locality was visited based on information provided to the field party by the Manitoba Museum. This study ultimately focused on the calcarenitic samples collected from the Van der Voort Farm locality, however, additional bonebed material collected from other localities along the Manitoba Escarpment was utilized in order to characterize and contextualize the Van der Voort Farm samples stratigraphically, paleoecologically and paleoenvironmentally. 


\begin{tabular}{|ll|}
\hline Table 1 & \\
Pertinent outcrop locations along the Manitoba Escarpment
\end{tabular}




\section{The Van der Voort Farm Calcarenite}

Mr. Henry Van der Voort reported that in the process of excavating a dugout for water for the family's cattle approximately 25 years previous to the 2006 field season, the backhoe struck a resistant layer around seven feet below the surface (pers. comm., 2006). Dr. Stephen Cumbaa, Richard Day, Dr. Charles Underwood and the author collected samples of this layer from spoil piles on the surface of the north and south banks of the dugout (Fig. 7).

\section{Acid Preparation}

Samples used for taxonomic and taphonomic (biostratinomic) surveys were disaggregated via soaking in baths of dilute acetic acid (5 to $\left.11 \% \mathrm{CH}_{3} \mathrm{COOH}\right)$ following the methods of Cumbaa and Tokaryk (1999). The acid baths were buffered using calcium orthophosphate $\left[\mathrm{Ca}_{3}\left(\mathrm{PO}_{4}\right)_{2}\right]$ as an added precaution against dissolution of apatitic vertebrate remains. Conducted at the $\mathrm{CMN}$, acid disaggregation of bonebed/bioclastic horizon samples began with measuring both the weight and volume of the selected specimens (Appendix I). Samples were subsequently soaked in tap water for 24 hours prior to acid immersion in order to limit the breakage of small vertebrate elements by the relatively violent reaction of the acid against dry pore space surfaces. Initially, samples from both the Van der Voort Farm and Thunder Hill localities were placed in acid immersion, however, only the former was successfully disaggregated; samples of the Thunder Hill material appeared unchanged even after four months of continuous immersion, and acid treatment was therefore terminated. An additional attempt was made to disaggregate the Thunder Hill material by placing specimens already treated in acid into an ultrasonic bath. This approach was also unsuccessful. 

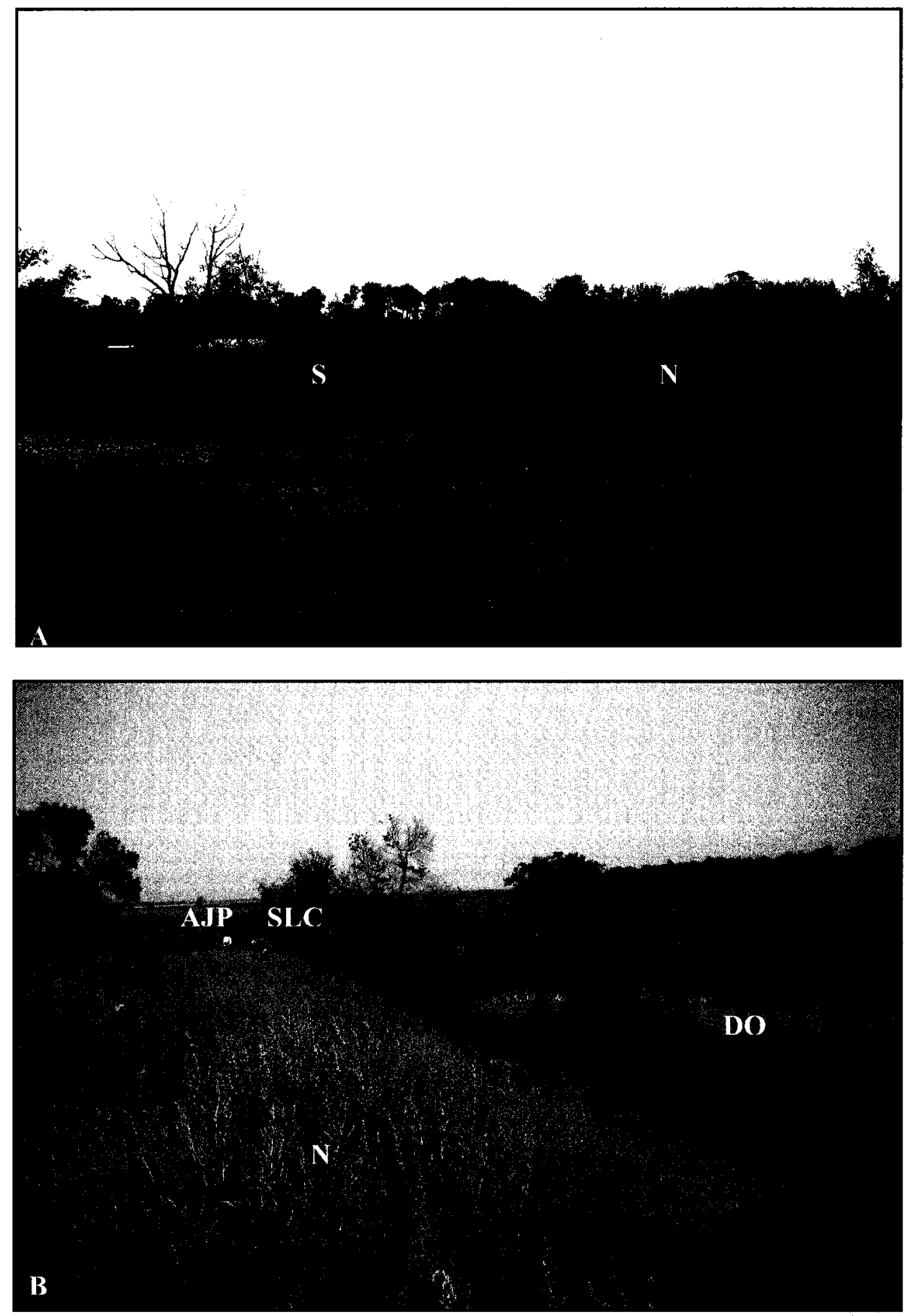

Figure 7: The Van der Voort Farm locality, near Riding Mountain, Manitoba, visited during the 2006 field season. (A) A view of the site from the southeast, with the north (N) and south (S) banks labeled (Photo by author). (B) A view of the site looking eastsoutheast across the site from the north (N) bank. The dugout pond (DO) is visible below, with Dr. Stephen L. Cumbaa (SLC) and the author (AJP) hard at work above (Photo courtesy of Dr. Charles Underwood). 
Acid baths were changed on a weekly basis, and continued (in the case of the Van der Voort Farm material) until the samples were completely disaggregated. The acid solution was carefully decanted through an extremely fine mesh sieve (No. $270-0.053$ $\mathrm{mm}$ ) in order to prevent the loss of any fine suspended particles. Once disaggregated, samples were rinsed and/or soaked in tap water until their $\mathrm{pH}$ returned to close to neutral (target $\mathrm{pH}$ was approximately 6.7, based on the measured $\mathrm{pH}$ of the water surrounding a block of Van der Voort Farm material soaked in tap water for 24 hours), measured with an Orion 210 APlus portable $\mathrm{pH}$ meter. Once neutrality was achieved, samples were transferred to a mesh screen for air drying. Dried samples were then ready for taxonomic and taphonomic analyses.

\section{Taxonomic Survey}

At Carleton University, the five dried samples of disaggregated Van der Voort farm material were weighed (Appendix I) and sorted by sieve into four size fractions (coarse: No.10 sieve $=1.68 \mathrm{~mm}$; medium: No.20 sieve $=0.841 \mathrm{~mm}$; fine: No. 40 sieve $=$ $0.420 \mathrm{~mm}$; and residue: $<0.420 \mathrm{~mm}$ ). The coarse and medium fractions of these samples were then examined microscopically in order to identify vertebrate remains to the least inclusive taxonomic level possible; the fine fraction and residue were deemed too small to be taxonomically informative. Microphotographs of vertebrate elements were taken primarily using a Sony Cyber-Shot Super SteadyShot DSC-H2 digital camera mounted on an Olympus SZX9 binocular microscope. Images were assembled using Helicon Focus 4.16 software as needed. For a complete list of the samples examined, see Appendix II. Fossils were identified by comparison with specimens in the collections of the CMN; through photographs of specimens in other museums (provided by Dr. 
Cumbaa); and from published figures and descriptions. Welton and Farish's (1993) field guide to the Cretaceous selachians of Texas and Radu's (2005) zooarchaeological fish guide proved particularly helpful.

\section{Comparative Taphonomic Census}

In order to investigate the taphonomic history of the Van der Voort vertebrate skeletal material, a comparative taphonomic census was undertaken using selected bonebed samples. A random sample of Van der Voort Farm material was compared against a similarly sized, randomly selected sample of material from the Bainbridge River (BR-3) locality in order to better contextualize the taphonomic features. The samples drawn from these localities only included material retained by a standard sized No. 20 $(0.841 \mathrm{~mm})$ sieve. The number of elements procured from both samples was kept approximately constant from one locality sample to the other to facilitate meaningful comparisons of the taphonomic features and faunal diversities of the two localities. Samples of bioclasts were only taken from the Van der Voort and Bainbridge River (BR3) localities due to the fact that these are the only bonebeds readily disaggregated via acid bath preparation. These elements were then assessed in terms of their size, shape, abrasive state and taxonomic affinity.

\section{Size}

Vertebrate microfossils used in this census were those collected from the standard size No. $10(1.68 \mathrm{~mm})$ and No. $20(0.841 \mathrm{~mm})$ sieve fractions. Elements that passed through these screens were not included in the survey due to their extremely small size and the paucity of useful taxonomic information they could provide. Due to the wide range of specimen sizes that could be found in a given sieve fraction, a counting tray with 
$1 \mathrm{~mm}$ marked increments was used to sort the specimens into $1 \mathrm{~mm}$ size categories, measured along an element's longest linear dimension. Though this method of size categorization will inevitably result in some fossils being closer in size to fossils in size classes other than their own, these categories nevertheless provide a good overall picture of the range of fossil sizes at a site (Blob and Fiorillo, 1996).

\section{Shape}

To further study the characteristics of the bioclasts as sedimentary particles, the sedimentological particle classification scheme of Sneed and Folk (1958) was employed as in Blob and Fiorillo (1996). Bioclasts in which one dimension was distinctly flattened were categorized as plate-shaped, such as the scales and bones of the opercular series of fishes. Bioclasts in which one dimension was greatly larger than the other two were categorized as elongate; for example tubular bones such as fin spines and the elongate teeth of the genus Enchodus. Finally, bioclasts which were approximately equidimensional were categorized as compact, and these included most vertebrae as well as the majority of coprolites.

\section{Abrasion}

To assess abrasion, Cook's (1995) slightly modified version of Fiorillo's (1988) scheme was used (Table 2). As the processes of abrasion are continuous rather than categorical by nature, data for intermediate stages was also recorded (as per Cook, 1995). Coprolites were not assessed for abrasion states due to their predisposition towards rounded shapes with smooth surfaces, which is ultimately due more to shaping during extrusion by the organism than to taphonomic factors. 
Table 2: Abrasion assessment scheme, based on Fiorillo (1988) and Cook (1995)

\begin{tabular}{|c|l|}
$\begin{array}{c}\text { Abrasion } \\
\text { Stage }\end{array}$ & \multicolumn{1}{c|}{ Description } \\
\hline Stage 0 & $\begin{array}{l}\text { Very angular: the bone (or tooth) is fresh and unabraded. Processes and } \\
\text { bone edges defined and sharp. }\end{array}$ \\
\hline Stage 1 & Subangular: the bone edges and processes slightly abraded and polished. \\
\hline Stage 2 & $\begin{array}{l}\text { Subrounded: bone edges well rounded, processes recognizable. Moderate } \\
\text { abrasion. }\end{array}$ \\
\hline Stage 3 & $\begin{array}{l}\text { Rounded: edges show high degree of rounding, processes generally } \\
\text { remnant. }\end{array}$ \\
\hline Stage 4 & Very rounded: fragments show a high degree of sphericity \\
\hline
\end{tabular}


Faunal Diversity and Abundance

Integration of relative faunal diversity and abundance into the survey permits the assessment of potential taxonomic biases in shape, size and abrasion trends as well as providing a means for a more meaningful comparison of the overall diversity of the two localities. The relative faunal abundance of each sample was assessed by counting all elements more than half complete as separate individuals. A slight modification of the Minimum Number of Elements protocol (Badgely, 1986); this approach permits the inclusion of broken elements into the faunal census while eliminating the possibility of counting individual elements multiple times. This is particularly important with samples, like those that have been screen-washed, where the probability of some elements being broken into multiple identifiable fragments is high (Blob and Fiorillo, 1996).

Finally, the size, shape, abrasion, and faunal/element diversity distributions were compared between the Van der Voort and Bainbridge River (BR-3) samples statistically using P.A.S.T. version 1.77 software (Hammer et al., 2001) via Chi-square tests, which provide an effective means of evaluating the similarity of distribution curves (Davis, 1986).

Petrographic Analysis

A comparative petrographic analysis was undertaken in order to further investigate the taphonomic and diagenetic history of the Van der Voort Farm calcarenites, as well as why certain biophospharenitic bonebeds broke down easily via treatment with acetic acid (e.g. Bainbridge River 3) while others did not (e.g. Bainbridge River 1, Carrot River, Thunder Hill). Polished thin sections of material collected from the Van der Voort Farm were compared against thin sections prepared from other vertebrate-rich bioclastic 
horizons along the Manitoba Escarpment, including Carrot River (DH-1), Thunder Hill and two localities along the Bainbridge River (BR-1 and BR-3). Polished thin sections were prepared at Carleton University and used for electron microprobe (EM) analysis, scanning electron microscope (SEM) imaging, and petrographic point count analysis.

\section{Electron Microprobe Analysis and Scanning Electron Microscopy}

Polished thin sections were examined at the CMN using a JEOL 733 SuperProbe Electron Microprobe. Slides were carbon-coated, and examined using a $15.0 \mathrm{kV}$ beam at $20 \mathrm{nA}$, with a $10 \mu \mathrm{m}$ spot size. A ZAF correction routine was utilized to analyze the composition of the cement binding the phosphatic bioclasts, as well as to characterize any other mineral grains of interest. A Philips XL30 ESEM (set at $15.0 \mathrm{kV}, 76 \mathrm{nA}, 5.2 \mu \mathrm{m}$ spot size) was subsequently used in order to produce higher resolution images of noteworthy features within the thin sections.

\section{Petrographic Point Count Analysis}

A Swift Automatic Point Counter Model E was used to conduct 500-point point count analyses from the thin sections in order to determine the relative abundance and composition of the constituent clasts and matrix. 


\section{RESULTS}

\section{Surficial Description of the Van der Voort Farm Calcarenites}

These calcarenitic blocks had weathered surfaces that were brownish-yellow to orange in color, while freshly broken surfaces were more yellowish-white to mediumlight grey in color. The blocks ranged up to about seven centimetres in thickness and rarely more than twenty centimetres in length. They are rich in calcareous materials, principally medium sand-sized prismatic calcite crystals that appear to have originated from the disaggregated remains of the outer layers of the shells of inoceramid bivalves. They also contain oysters and variable amounts of small vertebrate fossils which are disseminated throughout the calcarenitic blocks, with obvious shark and bony fish teeth on the surface. The blocks frequently appear massive and lack physical sedimentary structures; however vertebrate fossils occasionally appear to be concentrated along some laminae, which are also occasionally slightly inclined as though cross-laminated. Additionally, larger vertebrate fossils appear to typically lie parallel or sub-parallel to the bedding plane, however they do not appear to be preferentially aligned in that plane. This description also applies to calcarenite samples collected from along the banks of the Little Woody River (N 52 $47.526^{\prime}$, W $101^{\circ} 33.880^{\prime}$ ); calcarenite samples from this latter locality were examined briefly in order to compare them lithologically, sedimentologically, and faunally with the Van der Voort calcarenites.

\section{Systematic Paleontology}

This section describes vertebrate specimens and ichnofossils examined which could be identified to a useful taxonomic level and/or which have paleoecological significance. All other vertebrate materials examined for this study, the majority of which 
can only be tenuously identified if at all, are listed in Appendix II. The vast majority of the specimens described herein originated from material collected at the Van der Voort locality, which is the prime focus of this study. Material from other localities was also examined for comparative purposes, and for the comparative taphonomic survey that forms another part of this study. Where a given taxon occurs only in a site apart from the Van der Voort locality, or in more than one of the examined sites, all the alternate or additional relevant localities are mentioned. In general however, the specimen descriptions below are intended to describe the basic characteristics of each taxon based on materials collected from the Van der Voort locality. As such, the specimens figured in Plates 1 through 11 are representative samples of each taxon from the Van der Voort locality unless otherwise indicated.

\section{Class CHONDRICHTHYES \\ Subclass ELASMOBRANCHII \\ Order HYBODONTIFORMES \\ Family HYBODONTIDAE Owen, 1846 \\ Genus Hybodus Agassiz, 1837 \\ Hybodus butleri Thurmond, 1971: Plate I - Fig. 1}

Description - A single, small tooth with a distally inclined cusp; the root is not preserved; and it possesses a low crown with well developed, low medial and distal blades. It lacks distinct cusplets, and the carinae deviate only slightly from a straight line to form a very broad, obtuse angle. Longitudinal ridges are present on both the lingual and labial faces of the crown, reaching up to where the tip is broken on the lingual surface but only partway up the tip on the labial surface. 
Discussion - Though fragmentary, this single tooth from the Van der Voort material is assigned to $H$. butleri based on the nearly straight line formed by the mesial and distal carinae, the absence of lateral cusplets, and its small size.

Stratigraphic Remarks - The specimen described above is consistent with the description of $H$. butleri from previous work on Cenomanian marine vertebrates of the Manitoba Escarpment (Cumbaa et al., 2006), and has also been reported from AptianAlbian deposits in Texas (Welton and Farish, 1993).

\section{Family PTYCHODONTIDAE Jaekel, 1898}

Genus Ptychodus Agassiz, 1835

Ptychodus cf. P. decurrens Agassiz, 1843: Plate I- Fig. 2

Description - A single lateral tooth recovered from the Bainbridge River (BR-3) material examined, this low-crowned specimen measures approximately $7 \mathrm{~mm}$ in anteroposterior length. The crown is only slightly (and asymmetrically) convex, and it is roughly elliptical in shape when viewed occlusally. It is adorned with at least five transverse enameloid ridges which bifurcate into finer ridges in the marginal area; all ridges extend across the marginal area and are oriented nearly perpendicularly to the crown border. The root is somewhat box-like in shape and is also quite low, giving the tooth a total maximum height of approximately $2.5 \mathrm{~mm}$.

Discussion - In possessing a relatively low crown and in having the transverse and marginal area ridges oriented perpendicular to the crown border, this lone ptychodontid shark tooth most closely matches descriptions of the teeth of $P$. decurrens (Welton and Farish, 1993). Shimada et al. (2006) indicate that the inter- and intraspecific morphological variation of Ptychodus teeth is not well studied, and that identification can be further confounded due to the fact that the morphology of small, lateral teeth is 
apparently conservative within the genus. Therefore, while this tooth best matches published descriptions of $P$. decurrens, these considerations lead to its more conservative classification herein as Ptychodus cf. $P$. decurrens.

Stratigraphic Remarks - $P$. decurrens specimens are known from late Albian through Turonian strata (Williamson et al., 1991; Welton and Farish, 1993), and are common in Cenomanian deposits from Europe and Australia (e.g. Cappetta, 1987; Siverson, 1999). Abundant also in the Cenomanian of North America (e.g. Williamson et al., 1991; Cicimurri, 2001a; Shimada et al., 2006), $P$. decurrens is notably found in the Cenomanian-aged Pasquia Hills bonebeds, at both the Bainbridge River and Carrot River localities (Cumbaa and Tokaryk, 1999; Cumbaa et al., 2006), as well as in late Cenomanian deposits from northwestern Alberta (Cook, 2007).

Order LAMNIFORMES Berg, 1958

Family ANACORACIDAE Casier, 1947

Genus Squalicorax Whitley, 1939

Squalicorax volgensis Glickman in Glickman and Shvazhaite, 1971: Plate II - Fig. 1-6

Description - As with other species of Squalicorax, the teeth of $S$. volgensis possess anaulacorhizous roots, and lack both a nutrient groove or pit. On the labial side of the crown, the crown foot forms a prominent basal ledge overhanging a correspondingly deep basal concavity. The general pattern of an increasing distal inclination of the cusp moving distally along the tooth series is followed as in other members of the genus; anterior teeth possess the most erect cusps (Plate II, Fig. 1) and parasymphyseals(?) possess a mesio-distally compressed cusp and root, with the root being asymmetrical (where the mesial root lobe is slightly longer than the distal lobe) (Plate II, Fig. 2). The antero-lateral teeth of $S$. volgensis possess distally inclined cusps, which are inclined at 
an angle more reminiscent of the closely related $S$. curvatus than $S$. falcatus (Plate II, Figs. 3, 4a). Distal inclination of the cusp is most pronounced in lateral tooth specimens (Plate II, Figs. 5, 6). All teeth are low crowned, and the apex forms an acute angle. The mesial cusplet is essentially continuous with the main cusp, while the distal cusplet forms a well defined heel (e.g. Plate II, Fig. 3). The cutting edge is continuous along the mesial and distal sides of the crown, and unlike other species within the genus, the cutting edges tend to be smooth; limited and/or irregular serrations are occasionally present, as seen in the inset in Plate II, Fig. 4b.

Discussion - In the Van der Voort deposits the "crow sharks" of the genus Squalicorax are the third most common family-level taxonomic group of chondrichthyans represented after the odontaspidids and the cretoxyrhinids, and the vast majority of those specimens identified are of Squalicorax volgensis. Teeth of $S$. volgensis were also found in the material collected from the Little Woody River locality. First identified in Russia (Glickman and Shvazhaite, 1971), this species has also been described from elsewhere in Europe (Müller and Diedrich, 1991), Texas (Welton and Farish, 1993; Cappetta and Case, 1999), Saskatchewan (Cumbaa and Tokaryk, 1999; Cumbaa et al., 2006) and in northwestern Alberta (Cook, 2007). It has been noted as "conspicuously absent" from the Cenomanian Tobe locality in Colorado (Shimada et al., 2006).

Stratigraphic Remarks - Considered to be the most primitive member within the genus, S. volgensis ranges from the upper Albian to Santonian in the Cretaceous of North America (Shimada and Cicimurri, 2006). 
Squalicorax falcatus (Agassiz, 1843): Plate II - Fig. 7,8

Description - As previously described in S. volgensis, the teeth of Squalicorax falcatus possess anaulacorhizous roots, lack both a nutrient groove or pit, and the crown foot forms a prominent basal ledge overhanging a correspondingly deep basal concavity on the labial side of the crown. The main cusp tends to be narrow and erect in anterior teeth, while being low and distally inclined in lateral teeth. In general, the cusp is more erect than that seen in $S$. curvatus or $S$. volgensis. The cutting edges are finely to coarsely and regularly serrated continuously along the mesial and distal edges of the crown (Plate II, Fig. 8b).

Discussion - Due to the fragmentary nature of the serrated Squalicorax teeth recovered, it is difficult to discern whether they are representative of $S$. falcatus or Squalicorax curvatus (Williston, 1900). In Williston's (1900) original description of $S$. curvatus, however, he notes that one observable feature of the teeth is that they exhibit a convex labial crown surface. As the fragmentary teeth described here display flat labial crown surfaces, I therefore refer these specimens, along with those in the Little Woody River material, to $S$. falcatus. This species is known from many localities throughout the Western Interior (Russell, 1988), including Texas (Welton and Farish, 1993; Cappetta and Case, 1999), Kansas (Shimada and Fielitz, 2006), northwestern Alberta (Cook, 2007), and from further north along the Manitoba Escarpment (Cumbaa et al., 2006).

Stratigraphic Remarks - The chronological range of this species in North America is considered to be from the middle Cenomanian to Lower Campanian (Shimada and Cicimurri, 2006). 


\section{Family CRETOXYRHINIDAE Glickman, 1958}

Genus Archaeolamna Siverson, 1992

Archaeolamna sp.: Plate III - Fig. 1-6

Description - Parasymphyseal teeth are relatively small and possess an erect, mesio-distally compressed crown with divergent accessory cusplets (Plate III, Fig. 1). The root is also mesio-distally compressed, as well as asymmetrical, with the mesial extremity of the root being longer than the distal one. In all teeth, the root lacks a nutrient groove, and generally possesses one or two nutritive pits near the centre of the lingual protuberance. Anterior teeth also possess one pair of broad, divergent and triangular cusplets and a high main cusp that is slightly inclined distally in upper teeth and symmetrically erect in lower ones (Plate III, Figs. 3, 4). The roots of the anterior teeth tend to be quite symmetrical in upper teeth, slightly asymmetrical in lower teeth, and in both cases possess rounded extremities. Intermediate teeth are significantly smaller than those of adjacent files, and display a very narrow, distally inclined cusp (Plate III, Fig. 2). Lateral and postero-lateral teeth exhibit a more distinct distal inclination of the cusp, with the extremities of the root becoming shorter and more divergent distally along the tooth series (Plate III, Figs. 5, 6).

Discussion - Specimens assignable to Archaeolamna sp. account for the second most common identifiable chondrichthyan taxon in the Van der Voort material. The teeth described here as Archaeolamna sp. compare very favorably with those figured as Cretodus sp. by Case et al. (1990) as well as with those from the Pasquia Hills in the Manitoba Escarpment (Cumbaa et al, 2006). As with those from the latter locality, these teeth are found to differ from Siverson's (1992) description of $A$. kopingensis in their relative crown height and width, as well as in the orientation of the accessory cusps on 
the lateral teeth. Furthermore, while weak longitudinal folds in the enamel on the labial basal crown surface can be seen on lateral teeth (Plate III, Fig. 5b, inset), they would be expected to be more strongly developed in postero-lateral teeth than is seen here (Plate III, Fig. 6b, inset) in keeping with Siverson's (1992) description. These considerations, as well as the difference in geological age from Siverson's specimens (which were Campanian in age), lead me to agree with Cumbaa et al. (2006) in stating that this is likely a new species of Archaeolamna, though it will not be described here.

Stratigraphic Remarks - The type species of the genus Archaeolamna, A. kopingensis (Davis, 1890) was described by Siverson (1992) from an early to middle-late Campanian fossil shark assemblage in the Köpinge Sandstone in Sweden. It has since been identified from upper Campanian (Beavan and Russell, 1999) and upper Cenomanian (Cook, 2007) strata in Alberta, as well as misidentified as Cretodus sp. (in Case et al., 1990; corrected by Siverson, 1992) from strata in Saskatchewan which Case et al. (1990) originally misinterpreted as Coniacian, but which were later determined to be of Turonian age (Cumbaa and Tokaryk, 1999). It has also recently been tentatively identified from a Cenomanian deposit in Colorado (Shimada et al., 2006).

Genus Cretalamna Glickman, 1958

Cretalamna appendiculata (Agassiz, 1843): Plate III - Fig. 7, 8

Description - Generally, teeth of this species are moderately large and exhibit an erect and narrow cusp. The crown is smooth, with a strongly convex lingual face; an almost flat labial face; and a single pair of low, closely attached, divergent, and broadly triangular lateral cusplets. The crown is separated from the root by a narrow lingual dental band, and the root itself is strongly bilobate with flat, broad root lobes. It generally 
exhibits a low lingual protuberance that lacks a nutrient groove but that generally possesses a nutritive pit.

Discussion - This genus is commonly referred to in the literature as Cretolamna, however, a growing number of researchers (Siverson, 1999, Shimada et al., 2006) have pointed out that the original spelling by Glickman (1958) is Cretalamna, and so that usage is followed here.

Similar to the Tobe, Colorado and Pasquia Hills localities, C. appendiculata is a rare taxon among material collected from the Van der Voort locality, and those specimens collected here do differ somewhat from typical specimens of $C$. appendiculata. These differences include the more rounded shape of the extremities of the roots (e.g. Plate III, Fig. 7) and, in one instance, what appears to be evidence for an incipient second mesial cusplet (Plate III, Fig. 8). However, in all three specimens recovered, the roots and crowns appear to be significantly abraded, which may contribute to the rounded appearance of the roots, and the poorly defined second mesial cusplet may only be a pathological artifact. The lateral cusplets are significantly lower than specimens figured by Welton and Farish (1993), but are consistent with those figured from the Tobe locality (Shimada et al., 2006). Despite these differences, the smooth, erect, narrow cusp and the narrow lingual dental band are characteristic of $C$. appendiculata. The U- and V-shaped interlobe areas of the figured specimens are the basis for their identification as upper and lower teeth (Plate III, Figs. 7, 8) respectively.

Stratigraphic Remarks - Cretalamna appendiculata has a long stratigraphic range (Albian to Ypresian) and a cosmopolitan distribution (see Shimada et al., 2006 for summary). More pertinent to this study, this taxon is especially abundant in upper Albian 
and Cenomanian strata in Texas (Welton and Farish, 1993; Friedman, 2004); present in the late Cenomanian Dunvegan Formation in northwestern Alberta (Cook, 2007); and rare in the Cenomanian Tobe locality in Colorado (Shimada et al., 2006) and in the Cenomanian/Turonian strata of the Pasquia Hills in the Manitoba Escarpment (Cumbaa and Tokaryk, 1999; Cumbaa et al, 2006).

Genus Cretoxyrhina Glickman, 1958

Cretoxyrhina mantelli (Agassiz, 1843): Plate III - Fig. 9

Description - A single anterior tooth found in material collected at the Little Woody River locality measuring $25 \mathrm{~mm}$ in total tooth height, which possesses a robust, triangular, smooth-crowned cusp and no accessory cusplets. The razor-like cutting edges are continuous to the crown foot, and a broad dental band is present lingually. The root is strongly bilobed with a pronounced lingual protuberance marked by a single, pit-like nutritive foramen.

Discussion and Stratigraphic Remarks - Cretoxyrhina mantelli has been found globally in Cenomanian- through Campanian-aged strata (e.g. Cappetta, 1987; Müller and Diedrich, 1991; Siverson, 1992) including various Cenomanian deposits from the Western Interior Seaway of North America (e.g. Shimada and Martin, 1993; Welton and Farish, 1993; Cappetta and Case, 1999; Everhart et al., 2004; Siverson and Lindgren, 2005; Shimada et al., 2006; Cook, 2007). In the Pasquia Hills, teeth of C. mantelli are more common from Turonian-aged strata, however they are known to occur uncommonly in the Cenomanian-aged Carrot River bonebed (Cumbaa et al., 2006). 
CRETOXYRHINIDAE incertae sedis ("Cretoxyrhinid A"): Plate IV - Figs. 1, 2

Description - These fragmentary teeth have convex lingual and slightly convex to flat labial crown faces. The cutting edges are non-serrated, and continuous from the cusp to the cusplets. The main cusp is relatively tall, erect, and narrow, and the crown possesses a single pair of high, erect cusplets. The roots, though incomplete, display a single nutrient foramen at the centre of the moderately high lingual protuberance and there is a moderately developed labial basal shelf.

Discussion - These teeth are similar to both Archaeolamna and Cretolamna in some respects, however they possess cusps and cusplets that are higher, narrower, and more erect (as opposed to divergent) than in either of these taxa. They are classified here as "Cretoxyrhinidae incertae sedis" on the basis the absence of a nutrient groove (Welton and Farish, 1993), and are therefore designated as "cretoxyrhinid A". They approximate Archaeolamna most closely, and could in fact be either a new species or subspecies thereof; however, specimens are too few and fragmentary to say with certainty.

Stratigraphic Remarks - No informative stratigraphic remarks can be made regarding this taxon.

\section{CRETOXYRHINIDAE incertae sedis (“Cretoxyrhinid B”): Plate IV - Figs. 3, 4}

Description - Fragmentary teeth that are characterized by narrow primary cusps and a single pair of widely set, low, broadly triangular and erect cusplets. Both the lingual and labial crown faces are convex (with the labial face being less so than the lingual one) and the cutting edges are better defined on the main cusp than on the accessory cusplets. The root is very low and mesiodistally elongate. The lingual protuberance is low, there are no visible nutrient grooves, and the nutritive pits are small. 
Discussion - The distinctively wide set, broad, low, erect cusplets and the mesiodistally elongate and low root set these teeth apart from the other chondrichthyan taxa observed in the Van der Voort material. They are considered to be of cretoxyrhinid affinity based on the absence of a nutrient groove (Welton and Farish, 1993), and are therefore designated as "cretoxyrhinid B".

Stratigraphic Remarks - No informative stratigraphic remarks can be made regarding this taxon.

CRETOXYRHINIDAE incertae sedis (“Cretoxyrhinid C"): Plate IV - Fig. 5

Description - This taxon exhibits a narrow, erect primary cusp and very small accessory cusplets. The smooth cutting edges are continuous across the entire crown, and the primary cusp displays a convex lingual face and a flat labial face. The base of the crown is slightly constricted at the base, and marked by a prominent lingual dental band. There is no nutrient groove, and two small nutritive foramina are found on the lingual protuberance. The root is very high, with broad, tabular lobes and a V-shaped interlobe area.

Discussion - At $15 \mathrm{~mm}$ in length, this single specimen is one of the largest shark teeth recovered from the Van der Voort locality. The crown morphology, in particular the reduced accessory cusplets, is reminiscent of Cretoxyrhina mantelli (Agassiz, 1843), and while the primary cusp of "cretoxyrhinid C" is somehwhat narrower than some figured $C$. mantelli (e.g. Welton and Farish, 1993), it is generally similar to other published descriptions (see Siverson and Lundgren, 2005; Shimada et al., 2006) The root morphology, however, is strongly at variance with previously described specimens of $C$. mantelli, in that the root lobes of "cretoxyrhinid C" are much more tabular, and the root 
overall is much larger (root height even exceeds crown height). The absence of a nutrient groove is the basis for the designation of this taxon as "Cretoxyrhinidae incertae sedis", and while it is possible that a designation of Cretoxyrhina sp. could be in order, the author hesitates to do so based on a single specimen; therefore this specimen is conservatively designated as "cretoxyrhinid C".

Stratigraphic Remarks - No informative stratigraphic remarks can be made regarding this taxon.

Family ODONTASPIDIDAE Müller and Henle, 1839

Genus Carcharias Rafinesque, 1810

Carcharias amonensis (Cappetta and Case, 1975): Plate IV - Figs. 6-11

Description - Teeth of this species can be moderately large, with a broad-based cusp and generally one pair of cusplets in anterior teeth (e.g. Plate IV, Fig. 6) and up to two pairs on lateral teeth (e.g. Plate IV, Fig. 10). The lingual and labial faces are weakly convex, smooth, and bounded by smooth cutting edges, which are continuous onto the accessory cusplets. The cusp and cusplets alike typically exhibit some degree of distal inclination even in anterior row groups (e.g. Plate IV, Fig. 7), which becomes most pronounced in distal lateral teeth (e.g. Plate IV, Figs. 10, 11). The lingual dental band is well developed, and the relatively low root is marked with a nutrient groove in all cases. The lobes of the root are broad and tabular, and tend to converge in a V-shaped configuration.

Discussion and Stratigraphic Remarks - The teeth of Carcharias amonensis are the most abundant identifiable chondrichthyan remains from the Van der Voort locality. In Texas it may occur as early as the Late Albian (Welton and Farish, 1993), and is common in Cenomanian deposits from Texas (Welton and Farish, 1993; Cappetta and 
Case, 1999), from Minnesota (Case, 2001) and from the Belle Fourche and Mowry shales of South Dakota (Cicimurri, 2001b; 2004), as well as from Africa (Antunes and Cappetta, 2002) and Europe (Vullo et al., 2003), though it is notably rare in the lowermost Greenhorn Limestone at the Tobe locality in Colorado (Shimada et al., 2006). The first identification of $C$. amonensis in Canada was from the Bainbridge River material collected in the Pasquia Hills (Cumbaa et al., 2006), and it has also been subsequently recognized in the Dunvegan Formation of northwestern Alberta (Cook, 2007).

Carcharias cf. C. saskatchewanensis (Case et al., 1990): Plate V - Figs. 1-4

Description - Carcharias saskatchewanensis teeth are small and consist of a triangular main cusp and one pair of lateral cusplets (though paired mesial cusplets sometimes occur in lateral teeth). The main cusp is quite massive and the smooth cutting edge is continuous along the whole length of the crown. The lingual crown face is typically smooth, though it may occasionally have weak longitudinal ridges restricted to an area just apical of the well defined lingual dental band at the crown foot. The labial crown face may also exhibit longitudinal ridges near the crown base (e.g. Plate V, Fig. 2b, 2c). The root is bilobate with rounded extremities, and bears a deep, well developed nutrient groove incising its lingual protuberance.

Discussion - The teeth in this sample closely resemble Carcharias saskatchewanensis, however, where they do differ is primarily in that the accessory cusplets of $C$. saskatchewanensis are typically described as high and narrow or "needlelike" (Case et al., 1990; Welton and Farish, 1993; Shimada et al, 2006), while the specimens examined in this study possessed cusplets that are lower and more broadly triangular (e.g. Plate V, Fig. 1). Additionally, the strong labial basal ledge described by 
Welton and Farish (1993) is not observed in the Van der Voort specimens, and the main cusp appears to be slightly less massive here than in the Texan examples as well. However, the presence of sparse longitudinal ridges occurring on the labial crown foot and rarely on the lingual crown foot, and the overall similarity to other members of the genus Carcharias suggest that an assignment of Carcharias $\mathrm{cf}$. C. saskatchewanensis is appropriate for these specimens, as well as for some examined from the Little Woody River sample. Another, similar looking species of odontaspidid known from Cenomanian deposits in the Western Interior that displays longitudinal ridging along the labial crown face is Carcharias tenuiplicatus (revised to Cenocarcharias tenuiplicatus in Cappetta and Case, 1999) (Welton and Farish, 1993; Cumbaa et al., 2006; Shimada et al., 2006); Shimada et al (2006) note that lateral teeth of $C$. saskatchewanensis could be mistaken for $C$. tenuiplicatus. The specimens described herein, however, show a distinct absence of the narrow crown, the two pairs of lateral cusplets, and the numerous, well-marked and sharp longitundinal ridges extending midway up the crown from the crown base that typify specimens of $C$. tenuiplicatus. An additional specimen referred to this taxon is noteworthy for its pathologically abnormal split cusp (Plate V, Fig. 4).

Stratigraphic Remarks - Described originally from Early Turonian (Cumbaa and Tokaryk, 1999) strata in Saskatchewan (Case et al., 1990), Carcharias saskatchewanensis has subsequently been found only in Cenomanian strata, from Texas (Carcharias sp. A of Welton and Farish, 1993; Friedman, 2004), Colorado (Shimada et al., 2006), Kansas (Shimada and Martin, 1993), South Dakota (Cicimurri, 2001a; 2001b) and northwestern Alberta (Cook, 2007). Cumbaa et al. (2006) also hypothesized that $C$. saskatchewanensis 
is likely counted among a number of Carcharias-like odontaspidid teeth from the Bainbridge and Carrot River localities that remain as yet unidentified to species level.

Carcharias sp. A and Carcharias sp. B: Plate V - Figs. 5, 6

Description - Teeth designated here as species of the genus Carcharias other than Carcharias amonensis and Carcharias cf. C. saskatchewanensis are differentiated from the aforementioned taxa based on the morphology of their roots. Carcharias sp. A is recognized on the basis of a mesio-distally elongate root that is slightly asymmetrical, with the mesial lobe being more elongate than the distal lobe (Plate V, Fig. 5). The lobe extremities are rounded and the nutrient groove relatively weakly developed. Carcharias sp. B is recognized by the distinctively pronounced angle at which the root lobe angles away from the lateral cusplets (Plate V, Fig. 6). It also possesses very erect and broad triangular cusps and cusplets, and, as with Carcharias sp. A., rounded root lobe extremities and a weakly developed nutrient groove.

Discussion - Carcharias and Carcharias-like teeth constitute the second most abundant identifiable vertebrate remains within the material collected from the Van der Voort locality after teeth assignable to the teleost Enchodus. The presence of a nutrient groove on the roots of these teeth is suggestive of affinities with the odontaspidids, and while their overall cusp and root morphology is not unlike the species of Carcharias identified above, significant enough differences exist to warrant their exclusion from those species. Cumbaa et al. (2006) noted the presence of many Carcharias-like teeth in the Cenomanian deposits of the Pasquia Hills as well, and here as there they remain unidentified to species level. 
Stratigraphic Remarks - No informative stratigraphic remarks can be made regarding this taxon.

\author{
ACTINOPTERYGII \\ Order AMIIFORMES Hay, 1929 \\ Family CATURIDAE Owen, 1860 \\ unidentified caturid: Plate VI - Fig. 1-4
}

Description - The remains herein ascribed to an unidentified caturid include vertebrae and vertebral fragments as well as scales. Most of the vertebral remains are preserved as the broken dorsal or ventral halves of distinctively hollow vertebral centra (referred to as "caturid vertebral arch elements" in the taphonomic survey portions of this study). These structures are generally characteristically bipartite, with distinctive inner and outer surfaces. The inner surfaces appear to be composed of relatively solid looking bone, roughly circular in outline, and are notably concave, giving them a somewhat saddle-like appearance (Plate VI, Fig. 1). The outer surface meanwhile has an almost rice paper-like texture and coloration, and it encompasses the "saddle" dorsally/ventrally and laterally (Plate VI, Fig. 1). Where preserved, the neural and/or haemal arches tend to be low and nearly horizontal (Plate VI, Fig. 2)., Entire vertebrae are rarely found, however, in all cases these do not possess the saddle-like structures on the inner surfaces of the centrum (i.e. encompassing the notochordal canal), but are instead composed solely of the rice-paper textured bone (Plate VI, Fig. 2).

Scales of this taxon occur commonly in the Van der Voort material, and are generally ellipsoid in shape, occasionally slightly concave on the interior surface, and thicker around the margins than in the centre (Plate VI, Figs. 3, 4). They exhibit a distinctive pattern of parallel, slightly undulating longitudinal ridges that fan out posteriorly along 
the scale from the ossification centre (Plate VI, Fig. 3). This ossification centre is the most massive point on the scale and is marked by a relatively rugose patch situated near the anterior margin of the scale, which may also occasionally possess small, raised tuberosities. In some instances, rather than the typical rugose patch, this location is instead marked by a raised canal, which opens as a pore on the inner surface of the scale and posteriorly on the outer surface (Plate VI, Fig. 4).

Discussion - The broad haemal arches inclined to an almost horizontal position characterizes these vertebrae as a member of the superfamily Caturoidea, and the presence of paired, block-like neural arch ossifications place it in the family Caturidae (Grand and Bemis, 1998). These vertebrae are essentially identical to those of an articulated specimen of an unnamed caturid [Canadian Museum of Nature; CMNFV 17462] described from Turonian strata from the shores of Lac des Bois, Northwest Territories (Cumbaa and Murray, in press) (Fig. 8a, b, c). Fish scales preserved alongside the Lac des Bois specimen are clearly associated, and these too are an identical match for those found in the Van der Voort material, and are the basis for the inclusion of these scales within this taxon (Fig. 8a, d, e). Those scales that possess a pore are interpreted as lateral line scales.

Caturid fossils are generally rare in North America, but in addition to the material from the Northwest Territories, some caturid material has also been described from the Bainbridge River locality in the Pasquia Hills (Cumbaa et al., 2006). There, teeth with distinctively arrowhead-shaped tips and premaxillae have been found and assigned to an unidentified caturid. In the course of examination of material from the Bainbridge River (BR-3) locality for the purposes of comparative taphonomy for this study, further 
evidence for an unidentified caturid at the Bainbridge River (BR-3) locality was discovered in the form of two broken vertebral halves complete with saddle-shaped interior surfaces; one complete vertebra, and one very small scale inclusion within a coprolite.

Stratigraphic Remarks - No informative stratigraphic remarks can be made regarding this taxon.

Order PYCNODONTIFORMES Berg, 1940

Family PYCNODONTIDAE Agassiz, 1833

Pycnodontidae incertae sedis: Plate VI - Fig. 5

Description - Small fragments of plate-shaped bone with raised, enameloid ornamentation on the external surface.

Discussion - In addition to a number of small, characteristic teeth, Cumbaa et al. (2006) describe scattered fragments of bone with raised ornamentation from the Bainbridge River bonebed that compared favorably with that found on cranial bones of Micropycnodon Hibbard and Graffham (1945) from Kansas. Unlike the Bainbridge locality, however, no teeth have been found at the Van der Voort locality. While these few specimens are similar to those found from the Bainbridge River (Cumbaa, pers. comm.), their rarity and extremely fragmentary nature lead to their conservative designation as pycnodontidae incertae sedis.

Straigraphic Remarks - Though known from other Cenomanian-aged deposits in the Western Interior of the U.S. (e.g. Shimada et al., 2006), they are rare in Canadian deposits and have to date only been reported from the Bainbridge River bonebed (Cumbaa et al., 2006). No other informative stratigraphic remarks can be made regarding this taxon. 


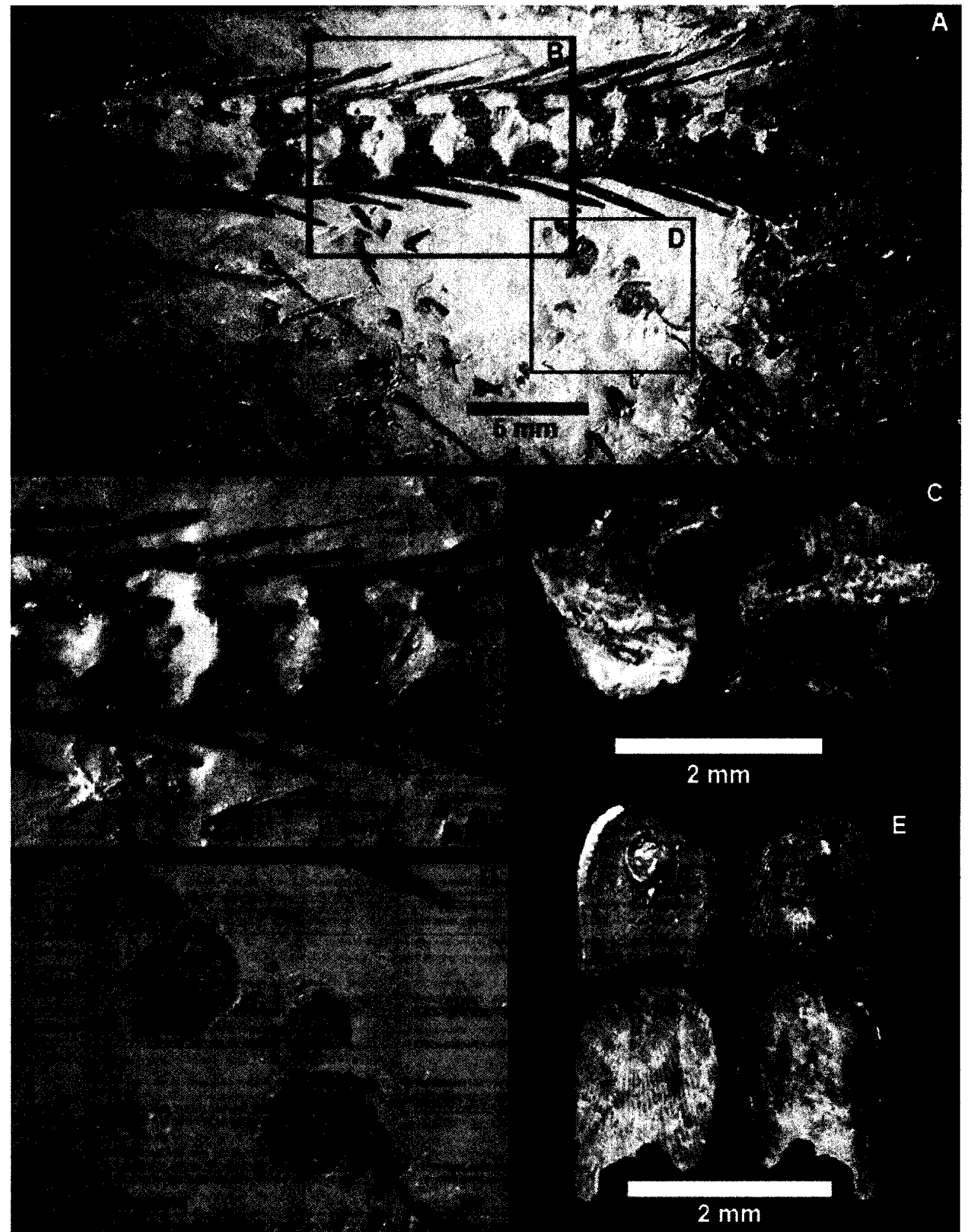

Figure 8: Comparison of an unnamed caturid specimen (CMNFV 17462) described from Turonian strata near Lac des Bois, Northwest Territories (Cumbaa and Murray, in press) with material recovered from the Van der Voort locality, Manitoba. A - Post-cranial section of articulated specimen CMNFV 17462. B and D - present magnified views of areas of CMNFV 17462 (B - vertebrae; D - scales) relevant for comparison with C (partial vertebrae - MM V-2958, left; MM V-2957, right) and E (MM V-2963, top - lateral line scale; MM V-2962, bottom non-descript scale) respectively. CMN - Canadian Museum of Nature; MM - Manitoba Museum 


\section{Order PACHYCORMIFORMES Berg, 1940 \\ Family PACHYCORMIDAE Woodward, 1895}

Genus Protosphyraena Leidy, 1857

Protosphyraena sp.: Plate VI - Fig. 6

Description - The distinctive rostral teeth of this species are long, flat, wide-bladed and triangular, with non-serrated edges and are very laterally compressed. The cutting edges on the tooth margins are gently concave, and both the lingual and labial faces of the teeth are also gently concave equally, making a distinction between the two faces of the teeth impossible based solely on isolated specimens.

Discussion - Unfortunately, species of Protosphyraena cannot be distinguished on the basis of isolated teeth. Though fragmentary, the specimens recovered here are at the least assignable to Protosphyraena sp. on the basis of their distinctive morphology. Protosphyraena is known from numerous places around the world (e.g. Woodward, 1908; Diedrich, 2001; Shimada et al., 2006), including the Manitoba Escarpment (Bardack, 1968; Cumbaa and Tokaryk, 1999). In addition to the Van der Voort specimens, Protosphyraena sp. was also discovered amongst the material collected from the Little Woody River locality.

Stratigraphic Remarks - Its earliest known occurrence in North America is from the mid-Cenomanian in the Graneros Shale (Everhart et al., 2004) and the Lincoln Limestone in Kansas (Stewart, 1898a). The youngest strata from which the genus is known are Campanian in age (Stewart, 1988b). 
Order ICHTHYODECTIFORMES Bardack and Sprinkle, 1969

Family ICHTHYODECTIDAE Crook, 1892

Genus Xiphactinus Leidy, 1870

Xiphactinus audax: Plate VI, Figs. 7, 8

Description - A small number of conical teeth were found that were oval in cross section and lacked carinae. They exhibited smooth surfaces covered with numerous, very fine longitudinal crack-like striations. Though not visible on all specimens due to adhering matrix, it was clear from select specimens that these teeth possess an ovalshaped pulp cavity (e.g. Plate VI, Fig. 7).

Discussion - Xiphactinus teeth are morphologically very similar to those of their sister taxon Ichthyodectes Cope, 1870, however, Bardack (1965) notes that the teeth of Ichthyodectes do not exceed $8 \mathrm{~mm}$ in height. The longest tooth preserved here is approximately one centimeter in length (Plate VI, Fig. 8), while the others are $6.5 \mathrm{~mm}$ or less. These smaller teeth are, however, clearly fragmentary, and despite their shorter length they almost all exceed the longest specimen in circumference. This observation, in addition to the stratigraphic ranges of the known North American species of Xiphactinus, leads to the assignment of these specimens to Xiphactinus audax.

Stratigraphic Remarks - Xiphactinus audax is a Late Cretaceous ichthyodectiform, which was one of the largest teleostean fishes in North America (e.g. $5.1 \mathrm{~m}$ in total length, Shimada and Everhart, 2004). Of the two North American species of Xiphactinus, $X$. audax is the stratigraphically older taxon, ranging from the Middle Cenomanian to the Lower Campanian of the Western Interior Sea, while $X$. vetus Leidy, 1856a, ranged temporally from the Middle Campanian to Lower Maastrichtian and geographically from the Atlantic Coastal Plain to the eastern Gulf of Mexico (Schwimmer et al, 1997b; Everhart et al., 2003, 2004). Though relatively few have been found, teeth assignable to 
Xiphactinus audax are not unknown from the Cenomanian-aged bonebeds of the Pasquia Hills (Cumbaa and Tokaryk, 1999; Cumbaa et al., 2006).

Unidentified ichthyodectid: Plate VI - Fig. 9

Description - A very small number of vertebrae were found possessing a distinctively wide anterior-posterior bar on the sides of the centrum.

Discussion - The strong anterior-posterior bar on the sides of the centrum compare favorably with the vertebra of ichthyodectiform teleosts, and with those described by Cumbaa et al. (2006)from the Pasquia Hills bonebeds.

Stratigraphic Remarks - Known with certainty to occur in deposits ranging in age from the Kimmeridgian to the Campanian (Patterson, 1993), ichthyodectiform fishes were inhabitants of shallow seas with a near worldwide distribution (Alvarado-Ortega, 2004). More specific stratigraphic remarks cannot be made regarding this taxon.

Order CROSSOGNATHIFORMES Taverne, 1989

Family PACHYRHIZODONTIDAE Cope, $1872 \mathrm{~b}$

Genus Elopopsis Heckel, 1856

Elopopsis sp.: Plate VI - Fig. 10

Description - Specimens consist of wide-based, laterally compressed, triangular teeth that curve lingually at the tips. They exhibit regular and distinctive longitudinal striations that extend from the base of the root almost to the apex.

Discussion and Stratigraphic Remarks - Elopopsis is relatively common in Africa and Europe (e.g. Taverne, 1976), and, though less common, is also known from North America. Cumbaa et al. (2006) note that it is not unusual to find teeth and jaw fragments of Elopopsis sp. in material from the Bainbridge River (BR-3) locality. 
Order SALMONIFORMES Greenwood et al., 1966

unidentified salmoniform: Plate VII - Figs. 1, 2

Description - The identification of an unidentified salmoniform within the Van der Voort material is based on the presence of numerous vertebrae (e.g. Plate VII, Fig. 1), which are round and relatively short in anterior-posterior length. The vertebrae possess a distinctive woven texture with many small fenestrae covering much of the vertebral surface that is characteristic of living salmoniformes, such as salmon and trout.

Discussion - Relatively complete specimens of these vertebrae are moderately common amongst those vertebrae collected here, and fragments of vertebrae bearing the unmistakable woven texture are even more common. Due to the completely disarticulated nature of these remains, it is at this point impossible to determine whether any of the variety of other unidentified teeth, jaw fragments, cranial elements, or opercular series elements could belong to this taxon; however the relative abundance of these vertebrae would make it likely. One basioccipital morphotype (Basiooccipital Morphotype \#3) in particular stands out (e.g. Plate VII, Fig. 2). This basioccipital is closely associated with the vertebral column, acting as the osseus anchor between it and the cranium, and though relatively uncommon, these basioccipitals possess a woven pattern of small fenestra on parts of their surface. This feature, combined with the overall robusticity of these particular basioccipital elements, suggest a potential affinity with the unidentified salmoniform(s). Comparable unidentified salmoniform vertebrae are also known from both the Bainbridge and Carrot River localities (Cumbaa et al., 2006).

Stratigraphic Remarks - No informative stratigraphic remarks can be made regarding this taxon. 
Order AULOPIFORMES Rosen, 1973

Suborder ENCHODONTOIDEI Berg, 1940

Family ENCHODONTIDAE Woodward, 1901

Genus Enchodus Agassiz, 1835

Enchodus cf. E. gladiolus (Cope, 1872): Plate VII - Figs. 3-5

Description - Teeth of Enchodus cf. E. gladiolus are triangular and moderately long, and exhibit a slightly sigmoidal curvature (Plate VII, Fig. 3). The mesial and distal carinae are unserrated, and the mesial edge tends to be better defined than the distal one (Plate VII, Fig. 4). Both the lingual and labial faces tend to be finely striated, and the faces are subequally convex (with the lingual face being slightly more convex).

Palatine bones of this species are anteroposteriorly elongate, and the largest collected from the Van der Voort locality measures approximately $14-15 \mathrm{~mm}$ in estimated anteroposterior length (Plate VII, Fig. 5). The palatine tooth of this specimen is approximately one-quarter to one-third complete, and is directed slightly anteroventrally. It is finely striated on both the lingual and labial faces.

Discussion - Goody (1976) diagnosed E. gladiolus based on the following: “...depth of palatine bone less than one-fourth its length; anterodorsal extent of maxillary grooves meets dorsal edge of palatine bone some distance behind tooth base; palatine tooth symmetrical in cross-section and laterally compressed; single, full-length, unserrated cutting edge anteriorly, posterior edge present only as a postapical barb; length of palatine tooth just more than one-half length of palatine bone; depth of palatine bone approximately one-third length of palatine tooth; dentary and palatopterygoid teeth moderately long and slightly sigmoidal, teeth finely striated on inner and outer faces...". The specimens from the Van der Voort locality are all disarticulated and mostly incomplete; making comparison with these characters difficult at times (though none of 
the Enchodus teeth found in the Van der Voort material possess a postapical barb). However, of the known North American species, these specimens most closely resemble E. gladiolus and are therefore referred to Enchodus cf. E. gladiolus. Teeth of Enchodus cf. E. gladiolus are the most common, specifically identifiable Enchodus teeth found at the Van der Voort site.

Stratigraphic Remarks - Enchodus is a genus with many nominal species ranging stratigraphically from the Albian to the Maastrichtian (Forey et al, 2003), while the known stratigraphic range of E. gladiolus is from the Turonian to the Upper Maastrichtian (summarized in Shimada et al., 2006). It has additionally been identified conservatively as Enchodus cf. E. gladiolus from the Cenomanian-aged deposits of the Tobe locality in Colorado (Shimada et al., 2006) and of the Bainbridge River bonebeds in the Pasquia Hills, Saskatchewan (Cumbaa et al., 2006).

\section{Enchodus cf. E. petrosus Cope, 1874: Plate VII - Figs. 6, 7}

Description - Teeth of Enchodus cf. E. petrosus are moderately long, triangular, and lanceolate (Plate VII, Fig. 6). The mesial and distal carinae are unserrated and are both well defined, extending right to the base. Both the lingual and labial faces are finely striated, and the faces are subequally convex (with the lingual face being slightly more convex).

Palatine bones of this species are relatively anteroposteriorly elongate, though less so than in Enchodus cf. E. gladiolus (Plate VII, Fig. 7). The palatine tooth of this specimen appears to be complete; it is directed ventrally and is characteristically asymmetrical in cross-section. 
Discussion - Goody's (1976) diagnosis for E. petrosus included the following criteria: “...palatine tooth asymmetrical in cross-section; smooth cutting edges placed anteriorly and laterally; length of palatine tooth greater than three-fourths length of palatine bone; palatopterygoid teeth and dentary teeth moderately long and straight with smooth outer faces and striated inner faces; teeth without postapical barbs...". Goody (1976) notes that the symphyseal tooth of the dentary of E. petrosus is the largest tooth on the dentary (though still smaller than the pterygoid teeth), and that they alone have two clear cutting edges (while the other dentary teeth appear to only have a well-defined anterolateral cutting edge). This suggests that it is possible that at least the teeth figured here (Plate VII, Fig. 6) represent symphyseal teeth. They do, however, bear fine striations on both the lingual and labial surfaces, whereas Goody's (1976) description of $E$. petrosus states that only the lingual faces bear striations. Goody (1976) further elaborates that while the one cutting edge of the palatine tooth lies in the anterior midline, that the second begins near the apex of the tooth at the posterior midline but passes into a posterolateral position near the base. The palatine figured here (Plate VII, Fig. 7) compares favorably with those figured by Goody (1976; e.g. Plate I, Fig. 9) in terms of overall shape, in the palatine-palatine tooth length ratio, and in the asymmetry of the cutting edges. Taking this comparison into account, and considering the relatively small number of these specimens recovered, along with the incompleteness of the remains, the conservative assignment of these fossils to Enchodus $\mathrm{cf}$. E. petrosus seems warranted.

Stratigraphic Remarks - Enchodus petrosus is known from Turonian through Maastrichtian strata of the Western Interior Seaway (Goody et al., 1976; Everhart et al., 2003). Cumbaa and Tokaryk (1999) also reported E. petrosus, along with E. gladiolus 
and E. shumardi from the mid- to late Cenomanian-aged Bainbridge River bonebeds, however, Cumbaa et al. (2006) reported that further study of the Bainbridge River Enchodus palatines failed to confirm its presence.

Enchodus cf. E. shumardi Leidy, 1856b: Plate VII - Figs. 8, 9

Description - Teeth of Enchodus cf. E. shumardi are straight and needle-like and typically relatively small (Plate VII, Fig. 8). Carinae are well marked and smooth, and continue to the base. The labial and lingual surfaces may or may not be striated.

Palatine bones of this species are anteroposteriorly shorter than those of either $E$. gladiolus or E. petrosus relative to the length of the palatine tooth (Plate VII, Fig. 9). Unlike in E. gladiolus, the palatine tooth points ventrally.

Discussion - Goody (1976) gave the following diagnosis for E. shumardi based on the morphology of the teeth and palatine bones: "length of palatine tooth greater than length of palatine bone; . . . palatopterygoid and dentary teeth straight and needle-like; postapical barb present on certain teeth...". Goody (1976) also stated that E. shumardi tends to be smaller in size than most other species of Enchodus. Of the many straight Enchodus teeth found in the Van der Voort samples, some are decidedly more needle-like in morphology than others. It is on this basis that I am conservatively distinguishing between the teeth of Enchodus cf. E. shumardi and Enchodus cf. E. petrosus. Also, as with the dental characters, the palatine characters can be difficult to apply to incomplete, disarticulated specimens. The palatine figured here (Plate VII, Fig. 9) is larger than would be expected, however, despite the tooth being broken the palatine bone itself appears to be whole, in which case the palatine-palatine tooth length ratio most closely resembles 
that described for E. shumardi, and is therefore here designated as Enchodus cf. E. shumardi.

Stratigraphic Remarks - Enchodus shumardi has been reported from strata ranging in age from Upper Cenomanian to mid-Maastrichtian from the Western Interior Seaway (e.g. Leidy, 1873; Stewart, 1900; Goody, 1976). Shimada et al. (2006) and Cumbaa et al. (2006) both report Enchodus cf. E. shumardi from the Cenomanian Tobe locality and Pasquia Hills bonebeds, respectively.

\section{Enchodus sp.: Plate VIII - Figs. 1-4}

Description - Included here are a variety of elements assignable to the genus Enchodus but that lack characters permitting specific designation.

Ectopterygoid fragment (Plate VIII, Fig. 1) - Broken posteriorly, this fragment preserves only the anterior portion of the original element. It is a relatively narrow lamina displaying the broken bases of four teeth along its lateral edge, and one large tooth at the extreme anterior end (the terminal ectopterygoid tooth).

Dentary fragments (Plate VIII, Fig. 2) - These fragments, which only preserve one small tooth each, present trios of distinctive finger-like processes that extend ventrally and medially to reinforce the symphysis.

Additional jaw fragments (Plate VIII, Fig. 3) - Fragments of jaw elements represented by thin laminae of bone bearing small, striated teeth.

Scales (Plate VIII, Fig. 4) - Consists of a broad, shield-shaped base, which is widest approximately one third of the way back from the anterior tip. Its outer surface is bisected longitudinally down the midline by a posteriorly-projecting flange that extends beyond the posterior margin of the base. Two pores are visible; one on the anterior tip of 
the scale on the dorsal surface, at the base of the anterior margin of the midlateral flange; the other in the midline and near the posterior margin of the base on the ventral surface. These two pores appear to communicate with one another via a simple tube.

Discussion - Remains of the genus Enchodus are the most common identifiable vertebrate remains collected from the Van der Voort locality, and were also present in the Little Woody River sample. While these consist primarily of teeth and their distinctively toothed palatines in the Van der Voort sample, there are also other elements that are much less frequently found. The ectopterygoid, dentary, and other jaw fragments described above and figured here generally match descriptions of the corresponding elements from E. petrosus (Goody, 1976), however they are considered here to be too fragmentary to warrant specific designation. The only literature describing the squamation of Enchodus that could be found by the author was also by Goody (1976), and the scale figured herein matches his description well. Enchodus petrosus possessed only two scales, represented by scutes, which in life would have lain on either side of the caudal peduncle, with the large base embedded in the body wall (Goody, 1976). Goody (1976) interprets these scutes as modified terminal lateral line scales, which explains the presence of the sensory pore allowing communication between the outer and inner surfaces.

In addition to belonging to any one or a combination of the species of Enchodus discussed above, it is equally possible for these additional elements to belong to another, as-yet-unknown, species of Enchodus. It is also possible that there are representatives of other, unknown species of Enchodus among the teeth and palatine specimens as well, considering they do not all match the descriptions of Enchodus gladiolus, E. petrosus, 
and/or E. shumardi exactly. As with the enchodontids of the Pasquia Hills (Cumbaa et al., 2006), the enchodontids of the Van der Voort locality will require further study.

Stratigraphic Remarks - No further informative stratigraphic remarks can be made regarding this taxon.

\section{Order ANGUILLIFORMES Regan, 1909}

cf. unidentified anguilliform: Plate VIII - Figs. 5-8

Description - Remains of this taxon from the Van der Voort locality consist entirely of the unfused halves of neural arches. These small elements range from somewhat ovoid or "ear-shaped" to sub-rectangular in shape, and curl anteromedially to form a process, which would articulate with the centrum. Most specimens feature a posterodorsally-oriented ridge on their lateral surface representing fused epineural elements.

Discussion - In their extensive review of the earliest known eel-like fossil fishes, Belouze, Gayet and Atallah (2003a, b) describe neural arches that consist of paired, autogenic plates that lack neural spines, and that meet at the dorsal midline but fail to fuse. This pattern was described as characteristic of the Anguilliformes, a pattern that is corroborated by the more recently described Libanechelys (Taverne, 2004). The elements described and figured in this study (Plate VIII, Figs. 5-8) compare favorably with the published descriptions of the neural arches of Cretaceous anguilliform taxa, however, due to their fragmentary nature as well as their lack of more specific diagnostic characteristics, they are here conservatively designated as cf. unidentified anguilliform.

Despite this open nomenclature, the discovery of cf. unidentified anguilliform from the Van der Voort locality is noteworthy from a biogeographic standpoint. The only 
other published description of Cretaceous eels in North America comes from the Santonian Niobrara Formation of Kansas (Wiley and Stewart, 1981). Wiley and Stewart (1981) describe Urenchelys abditus on the basis of a single specimen, and though undoubtedly an eel, Belouze, Gayet, and Atallah (2003b) suggest that its inclusion within the genus Urenchelys may require reevaluation. Early anguilliform remains have previously been tentatively identified from the Bainbridge River bonebeds (S. Cumbaa, personal communication), but apart from very brief mentions (Cumbaa and Tokaryk 1999; Schröder-Adams et al., 2001) they have not yet been described in any detail. In the course of investigating the comparative taphonomy of fossils from the Van der Voort and Bainbridge River localities, however, the author did identify a small number of the distinctive neural arch components, comparable to those described above from the Van der Voort locality. Those neural arches from the Van der Voort locality, meanwhile, being Lower Cenomanian in age, represent the earliest evidence of eels in North America, approximating the age of the earliest fossil eels known worldwide. This raises the possibility that the anguilliform lineage may perhaps be older than previously assumed, if they are already found in such paleogeographically distant locations as Cenomanian North America and Lebanon.

Stratigraphic Remarks - Among primitive anguilliforms, six genera are recognized from the Late Cretaceous of Lebanon: Urenchelys Woodward (1900); Anguillavus Hay (1903); Luenchelys Belouze, Gayet and Atallah (2003a); Abisaadia Belouze, Gayet and Atallah (2003b); Hayenchelys Belouze, Gayet and Atallah (2003b); and Libanechelys Taverne (2004). Among these genera, all are known primarily from lower and/or middle Cenomanian-aged strata (Belouze, Gayet and Atallah, 2003a, b; 
Taverne, 2004), and some (e.g. Urenchelys) range as late as the Santonian (Wiley and Stewart, 1981; Belouze, Gayet and Atallah, 2003b).

\section{EUTELEOSTEI incertae sedis \\ Plate IX - Figs. 1-7; Plate X - Figs. 1-5}

Description - This taxon encompasses a variety of cranial and mandibular elements found amongst the material from the Van der Voort locality which, as discussed below, are believed to be associated. The most distinctive of these will be described first, followed by those whose affinities with this taxon are less concrete.

Dentaries (Plate IX, Figs. 1-2) - The symphysis is moderately deep and strongly inturned, and moving posteriorly; the generally concave oral margin rises rather steeply. Moving further posteriorly along the dorsal margin, a large coronoid process is separated from the oral margin by a short convexity before resuming an even sharper rise, reaching its highest point anteriorly. The teeth, though missing from these specimens, were either six or seven in number, were quite small, and were restricted to a relatively small region of the anterior oral margin posterior to the symphysis. On the external surface, at the anterior edge of the base of the coronoid process and just postero-ventral to the tooth row there is a well marked depression for the insertion of the anterior maxillo-mandibular ligament. Finally, some of the specimens preserve one or two of the pores representing the mandibular sensory canal along their ventral margins.

Hyomandibulae (Plate IX, Figs. 3-5) - The head of the hyomandibular is single and the shaft is relatively narrow. The dorsal surface of the head, which articulates with the neurocranium, is angled away from the plane of the shaft by approximately $135^{\circ}$. The opercular process is positioned immediately beneath and behind the head and at a right 
angle to the shaft, and on the external surface a thin strut of bone can also be seen to project antero-ventrally at an angle of approximately $45^{\circ}$. Additionally, delicate sheets of bone can be observed connecting each process to each of its neighbors.

Fragmented maxillae (Plate IX, Fig. 6) - These elements are characterized by a single row of tiny teeth along the oral margin and by a prominent strengthening ridge running antero-posteriorly along the dorsoventral midline of the bone. The more complete fragments suggest that intact elements would have curved gently (with the tooth row being born on a slightly convex surface), though most are too fragmentary to determine this with certainty.

Fragmented preopercles (Plate IX, Fig. 7) - Though a small number of suspected preopercular fragments were found, only the one figured here was complete enough to suggest any sort of taxonomic affinity. The preopercular canal can be seen within the fragment near the anterior edge of the bone, along with five, unbranching, posteroventrally-directed tubes that branch off the main canal. The posteroventral margin of the bone is not preserved in this fragment, however, so whether these additional tubes reached right to the posteroventral margin or not is difficult to discern.

Other elements probably associated with this taxon include: Angulo-articulars (Plate X, Figs. 1, 2) - These elements are the result of the fusion of the angular and articular components. The articular surface for the quadrate is relatively shallow, and the retroarticular process is short. The coronoid process of these elements rise sharply anteriorly of the articular facet and these bones extend anteriorly as tapering laminae to their contact with the dentary. Both the lateral and medial faces of angulo-articular are 
marked by small, "V"-shaped depressions anterior of the articular facet, with the medial depression being the deeper of the two.

Quadrates (Plate X, Figs. 3, 4) - The fragments described here are broadly triangular in shape and possess small, robust articular condyles. The medial surfaces bear distinct grooves along their posterior margins for the reception of the symplectic.

Supraoccipitals (Plate X, Fig. 5) - A small number of these square-shaped elements were recovered, which bear a sizeable, low crest projecting posteriorly. They also possess a distinct transverse ridge, which is bounded anteriorly by two troughs which incompletely meet at the midpoint of the element.

Discussion - Many of the elements described above compare favorably with one or both of the named North American taxa of basal euteleosten fishes: Erichalcis arcta Forey (1975) and Avitosmerus canadensis Fielitz (2002). The high coronoid process and the steep anterior margin of the dentary are distinctive features of the mandible common among almost all of the Cretaceous basal euteleosts, and the mandibular tooth pattern observed here, while differing from most extant basal euteleosts, is one shared by four of the ten named genera: Avitosmerus; Erichalcis; Gaudryella gaudryi Pictet and Humbert (1866), from the Middle Cenomanian of Lebanon; and Ghabouria libanica Gayet (1988), also from the Cenomanian of Lebanon. The tooth pattern and the prominent strengthening ridge seen in the recovered maxillary fragments also compare well with the maxillae of Avitosmerus (Fielitz, 2002; personal observations of specimens CMN 17427, 17458 and 17459), as well as with the published description of the maxillae of Erichalcis (Forey, 1975). The hyomandibular, with its single articular head for articulation with the neurocranium, is unlike the double-headed articulation observed for Avitosmerus (Fielitz, 
2002; personal observation of specimen CMN 17427), however, it does compare well to the description for Erichalcis (Forey, 1975). The supraoccipital meanwhile, appears more Avitosmerus-like in its possession of a transverse ridge (Fielitz, 2002; personal observation of specimen CMN 17427) in addition to the low, posteriorly-projecting crest, which is seen in Erichalcis as well (Forey, 1975). Finally, one of the characters Fielitz (2002) uses to distinguish Avitosmerus from other Cretaceous basal euteleosts is that the four to five branches of the preopercular canal reach the edge of the preopercle, and though it is the author's opinion that very little of the figured preopercle's margin is missing, it is sufficiently broken to render this comparison equivocal.

In general, many similarities can be seen between the elements listed above and both Avitosmerus and Erichalcis, however, these elements do not furnish any definitive diagnostic characters. Nor do they provide any definitive diagnostic characters of the Euteleostei in general, for those pertain mostly to the caudal region (Johnson and Patterson, 1996; Arratia, 1997, 1999), and are far better suited for the diagnoses of articulated specimens. However, the similarity of these elements to those of Avitosmerus and/or Erichalcis is striking, and is suggestive that these elements do indeed belong to some manner of basal euteleostean(s), and thus that their assignment to euteleostei incertae sedis is warranted. It should be noted that disarticulated and/or isolated fossil material attributed to indeterminate basal euteleosts has been found in Late Cretaceous marine strata in other Canadian localities, including the Kanguk Formation (Cenomanian to Campanian) of Banks Island, Northwest Territories (Wilson, 1978) and the Turonianaged Kaskapau Formation near Watino, Alberta (Wilson and Chalifa, 1989). Cumbaa and Murray (in press) propose that Wilson's (1978) indeterminate basal euteleostean fossils 
from Banks Island may also be Avitosmerus canadensis. Additionally, in the course of conducting the comparative taphonomic survey portion of this study, the author did observe a single dentary fragment, among other rare fragments that compare favorably with those described above among the examined Bainbridge River material. Finally, some of the isolated bones figured by Leckie et al. (1992, figs. 9A, 9H) from the Fish Scale Marker Beds of the Shaftesbury Formation of northern Alberta (Early Cenomanian) do bear a striking resemblance to those described here, and Fielitz (2002) speculates that these may also be from basal euteleosts.

Stratigraphic Remarks - Fielitz (2002) provides an excellent table summarizing the ten monotypic genera of Cretaceous teleost fishes that have been described as basal members of the Euteleostei. They have been described from around the world, and among them there are two from the Cretaceous of North America: Erichalcis arcta Forey (1975), from the Lower or Middle Albian of the Northwest Territories, Canada; and Avitosmerus canadensis Fielitz (2002), from the Turonian-aged Lac des Bois locality, also in the Northwest Territories (approximately $870 \mathrm{~km}$ northwest of the locality where Erichalcis was collected). The majority of these taxa are known from Cenomanian strata.

\section{TELEOSTEI incertae sedis ("Teleost A") \\ Plate X - Figs. 6-8}

Description - Teeth considered here are characterized by slender, compressed and conical crowns. They have smooth surfaces and do not exhibit carinae. Typically they display a distinct lingual(?) curvature and where they are broken off at the root they reveal a very large central pulp cavity, giving the teeth an almost hollow appearance. 
Where these teeth are found associated with fragmentary jaw material, the broken roots of the teeth are distinctively oval-shaped in cross-section (e.g. Plate X, Fig. 7).

Discussion - Taxonomic identification of teleosts on the basis of isolated teeth is difficult due to the lack of comparative data concerning the range of dental variation within species. A noteworthy feature of the few jaw fragments associated with this taxon is the variation of the orientation of the teeth: some specimens exhibit teeth that were clearly laterally compressed (Plate X, Fig. 8), while others show distinct mesiodistal compression (Plate X, Fig. 7); whether this indicates different tooth bearing jaw bones of one species or different species is difficult to assess. Teeth of "Teleost A" are fairly common at the Van der Voort locality, and by being relatively simple, generalized teeth it is indeed possible that more than one species may be represented.

Stratigraphic Remarks - No informative stratigraphic remarks can be made regarding this taxon.

\section{TELEOSTEI incertae sedis ("Teleost B")}

Plate X - Fig. 9

Description - Teeth considered here are distinguished by broad, laterally compressed crowns, with smooth lingual and labial surfaces. They typically exhibit slight lingual curvature and the mesial and distal margins bear well-defined carinae, which are continuous from the apex to the base. Where the teeth are invariably broken at the base, they display large central pulp cavities, which give the teeth an almost hollow appearance.

Discussion - Teeth of "Teleost B" are less common at the Van der Voort locality than those of "Teleost A", and do not appear to overlap with them morphologically. They do, however, demonstrate some similarity in structure in the large opening of the pulp 
cavity at the base, and so could belong to a related species. Further comparisons with teeth of other osteichthyan taxa are needed to clarify their taxonomic identity.

Stratigraphic Remarks - No informative stratigraphic remarks can be made regarding this taxon.

\section{REPTILIA}

Order HESPERORNITHIFORMES Fürbringer, 1888

unidentified hesperornithiform(s): Plate XI - Figs. 1, 2

Description - A single tooth was found in the material examined from the BR-3 locality bearing a laterally flattened, posteriorly recurved crown with an expanded root (Plate XI, Fig. 1). The crown bears unserrated enamel edges on the anterior and posterior margins, and while the crown is strongly convex on the labial surface, it is comparatively planar on the lingual surface. The enamel stops at the base of the crown, and the tooth expands rapidly into the root. The lingual surface of the root is marked by a well-defined resorption pit.

Additionally, some scant skeletal fragments were also recovered from this same sample from the BR-3 locality (e.g. Plate XI, Fig. 2) which, based on their highly pneumatized nature, are also interpreted as avian in origin.

Discussion - Martin and Stewart (1977) note that hesperornithiform teeth are nearly planar on the lingual surface and strongly convex on the labial surface, while the teeth of Ichthyornis, another toothed bird common to the Late Cretaceous Western Interior Seaway of North America, are convex on both sides. While both hesperornithiform and ichthyornithiform birds have been previously identified from the Pasquia Hills bonebeds (Tokaryk et al., 1997), this tooth is interpreted as hesperornithiform on the basis of its nearly planar lingual crown surface, as well as due to 
its favorable comparison with other avian teeth identified as hesperornithiform from the Bainbridge River locality (Cumbaa et al., 2006, Figs. 7.4). No avian remains have been identified from the Van der Voort locality.

Tokaryk et al. (1997) described the hesperornithiform genus Pasquiaornis (including P. hardiei and P. tankei) from the Carrot River locality of the Pasquia Hills based on characters relating to distinctive post-cranial material and unrelated to dentition, and thus the tooth examined here is classified as an unidentified hesperornithiform since it is at the moment impossible to discern whether this tooth is that of a species of Pasquiaornis or of another hesperornithiform bird that has gone as yet undetected among the Pasquia Hills' bonebed material.

The other figured bone fragment identified as avian (Plate XI, Fig. 2) is identified as such due to its highly pneumatized nature as well as the favorable comparison of its general state of preservation with other identified avian fragments from the Pasquia Hills bonebeds. It is listed in this section as hesperornithiform as a matter of convenience; apart from being avian it is too fragmentary for a more specific designation.

Stratigraphic Remarks - Species of the hesperornithiform genus Pasquiaornis are known only from the Cenomanian-aged Carrot and Bainbridge River bonebeds in the Pasquia Hills of Saskatchewan (Tokaryk et al., 1997; Cumbaa and Tokaryk, 1999; Cumbaa et al., 2006). Hesperornithiforms in general, meanwhile, have been found in strata spanning from the Late Albian to the mid-Maastrichtian (summarized in Rees and Lindgren, 2005). 
Order TESTUDINES Linnaeus, 1758

unidentified testudine(s): Plate XI - Fig. 3

Description - A small number of largely plate shaped bones exhibit distinctive vascularization and moderately sculptured surface textures. Most are relatively small, plate-shaped bone fragments, while one particularly large piece exhibits a roughly triangular shape, with small foramina on parts of the surface and a prominent groove along one margin.

Discussion - The large, triangular bone fragment compares favorably with a marginal scute from a disarticulated carapace of a modern turtle in the comparative osteological collections of the Canadian Museum of Nature, suggesting this bone originated at the margin of the carapace. Other, plate-shaped elements exhibit surficial texturing reminiscent of turtle plastron elements, and so are tentatively assigned to "unidentified testudine(s)". One or more species of turtle may be represented by these specimens, however, their fragmentary nature and their rarity makes this impossible to quantify. A limited number of turtle elements are known from the Carrot River bonebed, in the way of the right humerus of a protostegid (Family Protostegidae Cope, 1872) and other fragments of unknown familial designation (Nicholls et al., 1990).

Stratigraphic Remarks - No informative stratigraphic remarks can be made regarding this taxon. 
Order PLESIOSAURIA Blainville, 1835

Superfamily PLIOSAUROIDEA Welles, 1943

Family PLIOSAURIDAE Seeley, 1874 (s. O'Keefe, 2001)

Genus Brachauchenius Williston, 1903

cf. Brachauchenius sp.: Plate XI - Fig. 4

Description - In the Van der Voort material, this taxon is known only from a $4 \mathrm{~cm}$ long impression of a tooth crown preserved on the surface of a large, unprepared block. The tooth crown that made the impression was clearly conical in shape, relatively elongate, slightly recurved, and the surface was marked by relatively fine longitudinal ridges that extended from the base of the crown almost to the apex. These ridges run more or less parallel with one another, and progressively bifurcate basally.

Discussion and Stratigraphic Remarks - No complete skeletons are known, however, Brachauchenius is hypothesized to have been a large pliosaurid with an estimated total body length of large individuals of about 11 metres (Carpenter, 1996). The genus is represented by a single species, $B$. lucasi Williston, 1903, where the type specimen is known from the Greenhorn Limestone, and the paratype from the Eagle Ford Group, both in Texas. In Kansas, $B$. lucasi is reported to range from the Middle Cenomanian Lincoln Limestone to the lower Middle Turonian Fairport Chalk (Schumacher and Everhart, 2005), as well as by Ligget et al. (2005) from near the Graneros Shale - Lincoln Limestone contact. Most recently, Albright et al. (2007) reported two new specimens of $B$. lucasi, one of which included the first known pectoral and pelvic elements, from the Early or early Middle Turonian of the Tropic Shale from southern Utah. Tarlo (1960) demonstrated that tooth morphology can be used reliably in order to make generic identifications among pliosaurs, and in Carpenter's review of short-necked plesiosaurs of the Cretaceous North American Western Interior (1996), he identifies "striations [=ridges] 
on teeth branching toward roots" as one of the diagnostic characters for Brachauchenius. Considering, however, that my identification is based only on an isolated impression in the Van der Voort material, I refer it to cf. Brachauchenius sp. Incomplete teeth recovered from the Cenomanian-aged Tobe locality in Colorado (Shimada et al., 2006) and from Turonian deposits in South Dakota (Stewart and Martin, 1993) have been the basis of the same taxonomic treatment.

\section{PLESIOSAURIA incertae sedis: Plate XI - Fig. 5}

Description - The essentially square-shaped bone shows distinct articular surfaces at either end. The element is both widest and deepest at the ends and both narrows and tapers towards its midpoint, giving it a slight hourglass-like appearance. Where exposed, the internal structure of the bone is observed to be highly porous and of endochondral derivation.

Discussion - The small phalangeal element figured here represents the only plesiosaur material recovered from the Bainbridge River sample that was examined for taphonomic comparison with material from the Van der Voort locality. It is, however, not distinctive enough to assign to a more specific taxon. Plesiosaur remains, primarily teeth, have been previously described from the Pasquia Hills bonebeds (Cumbaa and Tokaryk, 1999; Cumbaa et al., 2006) and include remains assignable to elasmosaurs, pliosaurs, and polycotylids. Though small post-cranial elements such as phalanges are also known from these localities, they are often much more difficult to assign to specific taxa.

Stratigraphic Remarks - No informative stratigraphic remarks can be made regarding this taxon. 
VERTEBRATA(?) incertae sedis: Plate XI - Figs. 6-8

Description - The specimens are represented by microcoprolites, which are preserved in the Van der Voort material as small phosphatic pebbles. They vary in shape from cylindrical to circular to spheroidal; they may rarely exhibit a faint spiral (e.g. Plate XI, Fig. 6), and can measure up to just over a centimeter in maximum dimension. They are massive, and their color varies from buff white to light brown, with the occasional specimen being medium to dark brown. Several specimens were found to have inclusions consisting of fragmented and/or whole fish bones and scales (e.g. Plate XI, Fig. 7).

Discusssion - Late Cretaceous sediments deposited within the Western Interior of North America commonly preserve fecal remains (e.g. Savrda and Bottjer, 1993; Hattin, 1996; Schröder-Adams et al., 2001; Anderson and Kowallis, 2004; Friedman, 2004). Savrda and Bottjer (1993) differentiate between two types of fecal matter found in finegrained sediments from the Western Interior on the basis of size: fecal pellets, which are generally less than four millimetres in maximum dimension, and coprolites, which are generally several centimeters in maximum dimension. They attribute the production of the former mostly to zooplankton and benthic macroinvertebrates, while the latter is generally attributed to vertebrates, especially when the coprolites contain macrovertebrate inclusions (e.g. bones, teeth and/or scales). Based on size, the majority of the fecal matter found in material from the Van der Voort locality would be classified as fecal pellets under this classification scheme. However, many of these small "fecal pellets" contain vertebrate inclusions, including bones, teeth and scales. The abundance of osteichthyan vertebrae that measure two millimetres in length or less in the samples examined here suggest that there were many fish here that would have been no more than a few 
centimeters long in total length, and these fish could surely produce coprolites four millimetres or less in maximum dimension. It is on the basis of the small size of the fish known from these deposits, and the inclusion of macrovertebrate remains that this fecal material is therefore referred to here as "microcoprolites", acknowledging both their small size and inferred vertebrate origin.

One exceptional specimen was found whose color and composition was consistent with other microcoprolites, however, it exhibits a highly sculptured "ropey" surface texture (Plate XI, Fig. 8). It is difficult to imagine how a piece of feces, assumed to have a paste-like consistency at the time of excretion (Hattin, 1996), could have survived the rigors of defecation with so much surface detail preserved intact; therefore this specimen is interpreted as an enterospira. Enterospirae from the Western Interior have been previously described from the Upper Cretaceous Niobrara Formation in Western Kansas (Stewart, 1978), where they were attributed to selachians. The twisting, spiraled texture seen in this specimen suggests it would have been formed in an intestine containing a spiral valve, which is consistent with the intestinal structure of both chondrichthyans and non-teleost osteichthyans (Kardong, 2002), while a distinct constriction at one end suggests that this fecal mass was at the distal-most end of the digestive tract at the time of the animal's death (Hattin, 1996). Other microcoprolites displaying slight spiral morphologies could also be interpreted to be of either chondrichthyan and/or non-teleost osteichthyan origin (Stewart, 1978; Friedman, 2004), however they are relatively rare compared to those which are simply cylindrical, circular or spheroidal in shape. These latter microcoprolites, while being potentially attributable to birds, reptiles, or teleostean fishes (Hattin, 1996), are in this case interpreted to be most likely of teleostean derivation 
based on the abundant remains of these fishes preserved here, in contrast to the low numbers of reptiles and birds.

Stratigraphic Remarks - No informative stratigraphic remarks can be made regarding this taxon.

\section{Comparative Taphonomic Census}

In order to assess the relative importance of biostratinomic processes affecting the vertebrate fossils preserved at the Van der Voort Farm locality, a random sample was taken and examined for signs of abrasion and sorting by both shape and size. A second random sample, taken from material collected at the Bainbridge River (BR-3) locality, was examined in an identical manner in order to place observations made of the Van der Voort fossils into context.

Shape

Chi-square testing of the counts of elements across the three microfossil shape categories demonstrated a statistically significant difference between the two distributions (Table 3). While the two samples differed little in terms of the number or proportion of elongate-shaped elements (with the Bainbridge River (BR-3) sample having only slightly more), greater disparity was observed between plate- and compact-shaped elements (Fig. 9). The Bainbridge River (BR-3) sample was found to have a greater number and proportion of compact-shaped elements (by a difference of 5.84\%), while the Van der Voort sample was found to contain a greater number and proportion of plateshaped elements (by a difference of $7.18 \%$ ) (Table 4). 


\begin{tabular}{|c|c|c|c|c|c|}
\hline \multicolumn{7}{|c|}{ Statistical Comparison of Taphonomic Indicators } \\
\hline & VDV & BR-3 & Deg.s Freedom & $\chi^{2}$ & $p$ (same) \\
\hline $\begin{array}{c}\text { Comparison of Shape } \\
\text { Distributions }\end{array}$ & $\mathrm{N}=1770$ & $\mathrm{~N}=1805$ & 3 & 19.709 & 0.00019499 \\
\hline $\begin{array}{c}\text { Comparison of Size } \\
\text { Distributions }\end{array}$ & $\mathrm{N}=1770$ & $\mathrm{~N}=1805$ & 16 & 226.04 & $4.1024 \mathrm{E}-39$ \\
\hline $\begin{array}{c}\text { Comparison of } \\
\text { Abrasion Distributions }\end{array}$ & $\mathrm{N}=1707^{\star}$ & $\mathrm{N}=1610^{\star}$ & 9 & 336.4 & $4.85 \mathrm{E}-67$ \\
\hline
\end{tabular}

Table 3: Statistical comparison via Chi-square tests of taphonomic indicators scored for the clasts recovered from the Van der Voort (VDV) and Bainbridge River (BR-3) samples used for the comparative taphonomic census. The column " $p$ (same)" indicates the probability that the distribution curves from the two samples are the same. *The number of clasts used for the abrasion distributions varies from the other distribution values due to the exclusion of coprolites. 


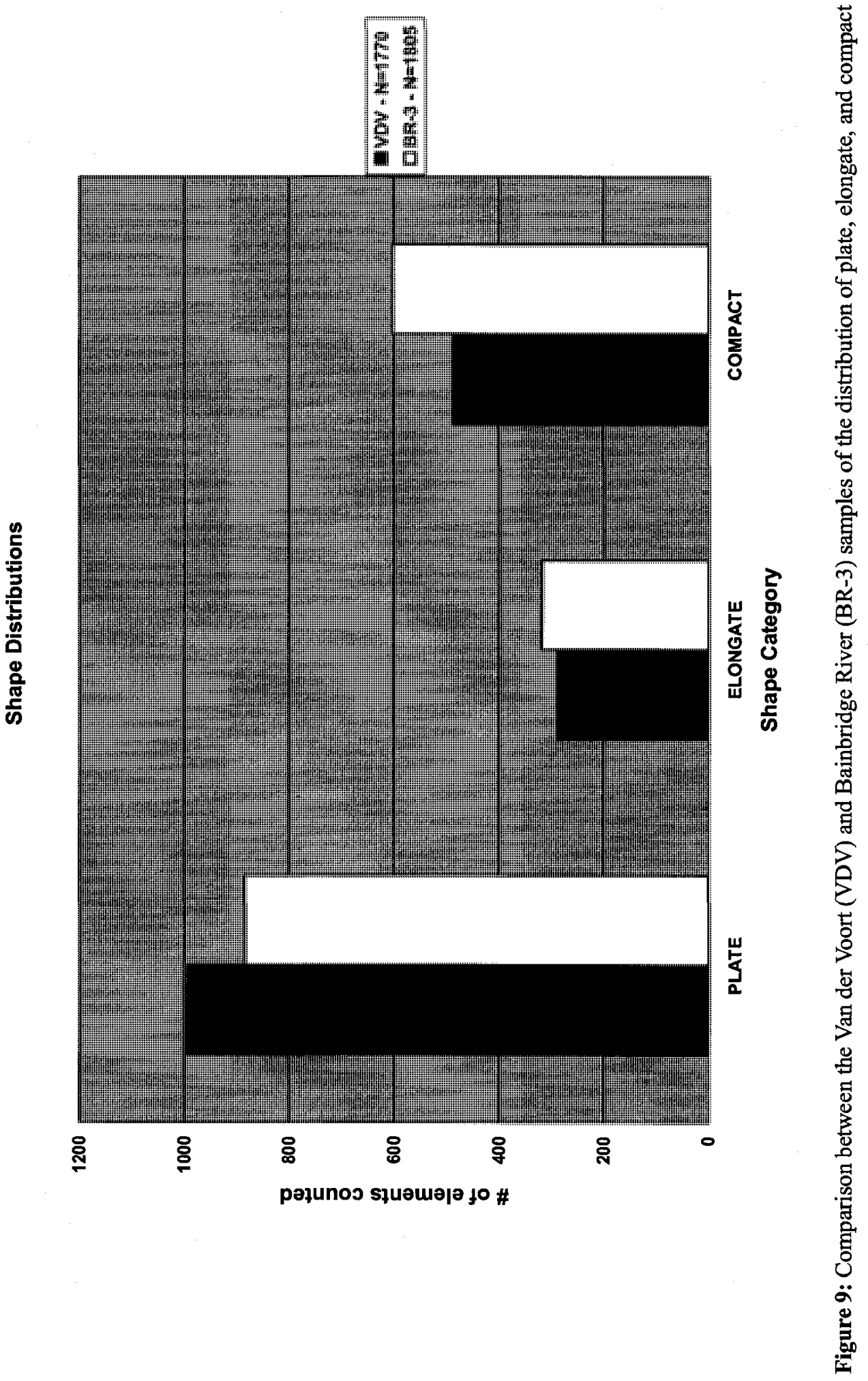




\begin{tabular}{|c|c|c|c|c|}
\hline \multicolumn{5}{|c|}{ Percent Differences between Taphonomic Variables } \\
\hline \multirow{2}{*}{ Taphonomic Variable } & \multirow{2}{*}{ Variable Category } & \multicolumn{2}{|c|}{ Sample \%s } & \multirow{2}{*}{ Difference } \\
\hline & & VDV & BR-3 & \\
\hline \multirow{3}{*}{ Shape } & Plate & 56.16 & 48.98 & 7.18 \\
\hline & Elongate & 16.27 & 17.62 & -1.35 \\
\hline & Compact & 27.57 & 33.41 & -5.84 \\
\hline \multirow{20}{*}{ Size Increment (mm) } & $0-1$ & 6.05 & 0.00 & 6.05 \\
\hline & $1-2$ & 45.76 & 34.07 & 11.69 \\
\hline & $2-3$ & 30.00 & 35.62 & -5.62 \\
\hline & $3-4$ & 11.86 & 17.06 & -5.20 \\
\hline & $4-5$ & 2.43 & 5.82 & -3.39 \\
\hline & $5-6$ & 1.41 & 4.32 & -2.91 \\
\hline & $6-7$ & 1.30 & 1.27 & 0.03 \\
\hline & $7-8$ & 0.45 & 0.83 & -0.38 \\
\hline & $8-9$ & 0.40 & 0.33 & 0.06 \\
\hline & $9-10$ & 0.11 & 0.33 & -0.22 \\
\hline & $10-11$ & 0.00 & 0.11 & -0.11 \\
\hline & $11-12$ & 0.00 & 0.00 & 0.00 \\
\hline & $12-13$ & 0.11 & 0.00 & 0.11 \\
\hline & 13-14 & 0.06 & 0.06 & 0.00 \\
\hline & 14-15 & 0.06 & 0.06 & 0.00 \\
\hline & $15-16$ & 0.00 & 0.06 & -0.06 \\
\hline & $16-17$ & 0.00 & 0.00 & 0.00 \\
\hline & $17-18$ & 0.00 & 0.00 & 0.00 \\
\hline & $18-19$ & 0.00 & 0.00 & 0.00 \\
\hline & $19-20$ & 0.00 & 0.06 & -0.06 \\
\hline \multirow{9}{*}{ Abrasion State } & 0 & 1.29 & 0.00 & 1.29 \\
\hline & 0.5 & 19.63 & 2.24 & 17.39 \\
\hline & 1 & 47.04 & 45.71 & 1.33 \\
\hline & 1.5 & 18.86 & 28.51 & -9.65 \\
\hline & 2 & 9.96 & 16.40 & -6.44 \\
\hline & 2.5 & 1.41 & 4.66 & -3.25 \\
\hline & 3 & 1.41 & 2.17 & -0.77 \\
\hline & 3.5 & 0.18 & 0.12 & 0.05 \\
\hline & 4 & 0.23 & 0.19 & 0.05 \\
\hline
\end{tabular}

Table 4: Percent differences between the numbers of clasts counted for and within each taphonomic variable. Positive differences represent a comparative surplus for the Van der Voort (VDV) sample; negative differences represent a comparative surplus for the Bainbridge River (BR-3) sample. Note that $\mathrm{N}_{V D V}=1770$ and $\mathrm{N}_{\mathrm{BR}-3}=1805$ for Shape and Size Increments, while $\mathrm{N}_{\mathrm{VDV}}=1707$ and $\mathrm{N}_{\mathrm{BR}-3}=1610$ for Abrasion State due to the exclusion of coprolites. 
Size

A statistically significant difference was found to exist between the microfossil size increment distributions from the two samples (Table 3). Differences between elements equal to or greater than $6 \mathrm{~mm}$ in length were negligible, but amongst size increments smaller than $6 \mathrm{~mm}$ in size some distinct differences were observed (Fig. 10). The Van der Voort sample was found to contain greater numbers and proportions of elements ranked into the $0-1$ and $1-2 \mathrm{~mm}$ size classes (by differences of $6.05 \%$ and $11.69 \%$ respectively) (Table 4 ). The Bainbridge River (BR-3) sample meanwhile was found to have a distinctly greater number and proportion of elements ranked into the $2-3$, 3-4, 4-5 and 5-6 mm size classes (by differences of 5.62\%, 5.20\%, 3.39\%, and 2.91\% respectively).

Abrasion

Of the three taphonomic variables assessed, Chi-square testing revealed the greatest statistically significant difference exists between the abrasion state distributions of the two samples surveyed (Table 3). The number of clasts that were found to be rounded to very rounded (scoring from 3 to 4 on the abrasion scale) were rather small in both samples, and the differences from one sample to the other were minimal (Fig. 11). Both samples were dominated by subangular elements scoring a 1 on the abrasion scale (accounting for $47.04 \%$ of the Van der Voort sample and $45.71 \%$ of the Bainbridge River (BR-3) sample), though once again the difference between these two values is minimal (examples of the abrasion states can be seen in Fig. 12). The real differences lie in the number of elements scoring $0.5,1.5,2$, and 2.5 on the abrasion scale. Elements scored as 0.5 (between "angular" and "subangular") accounted for $19.63 \%$ of the Van der Voort 


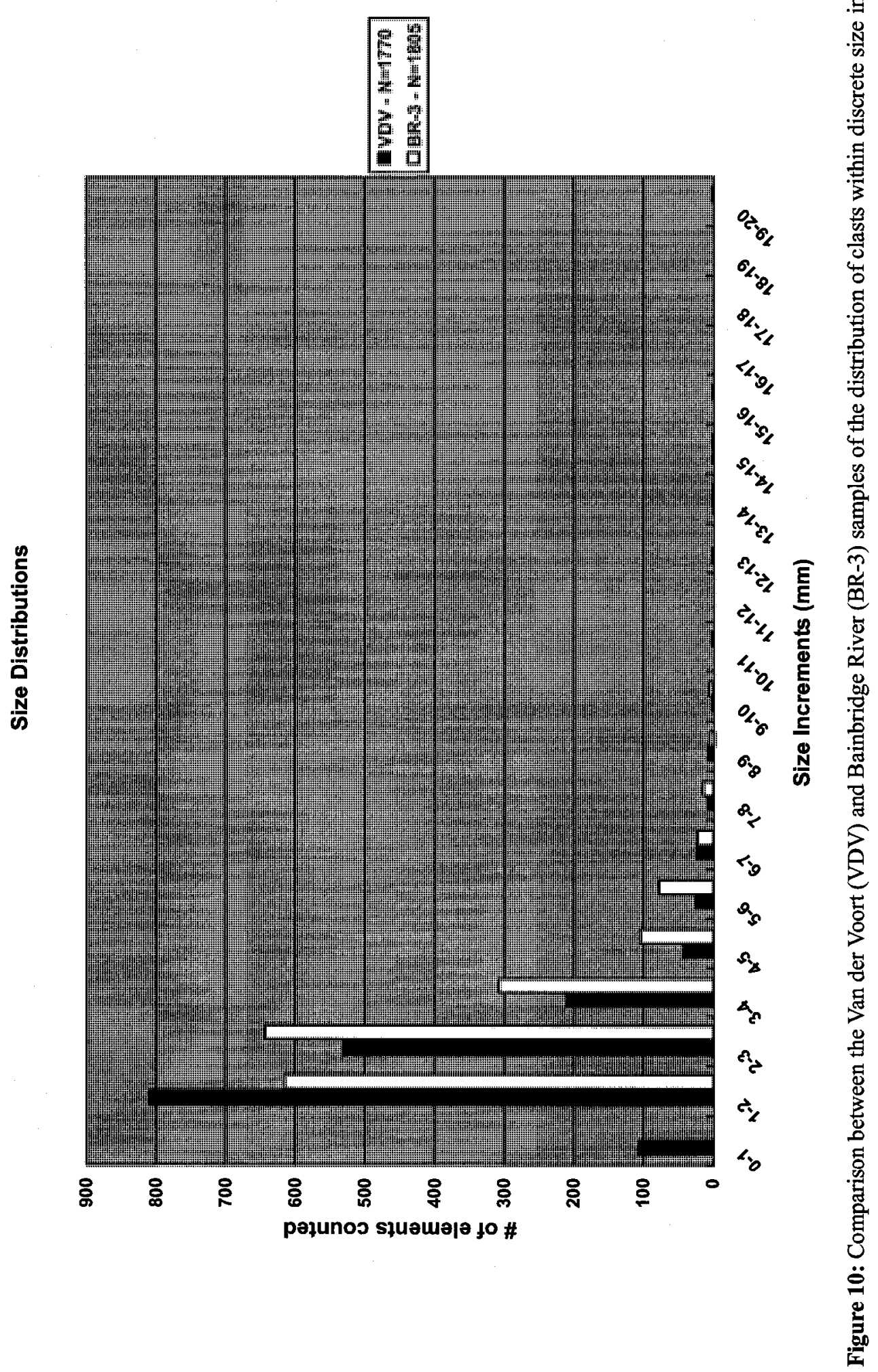




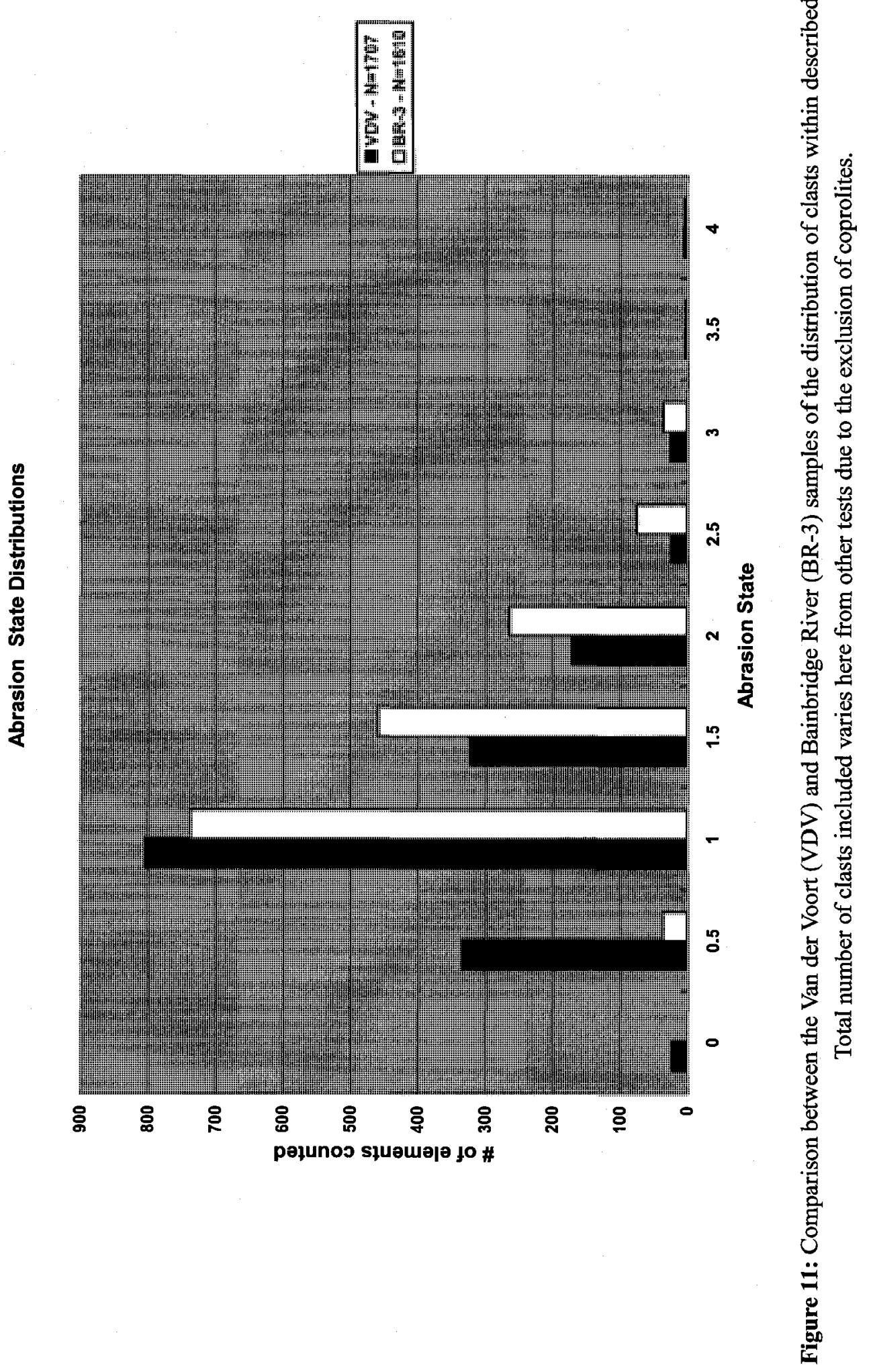




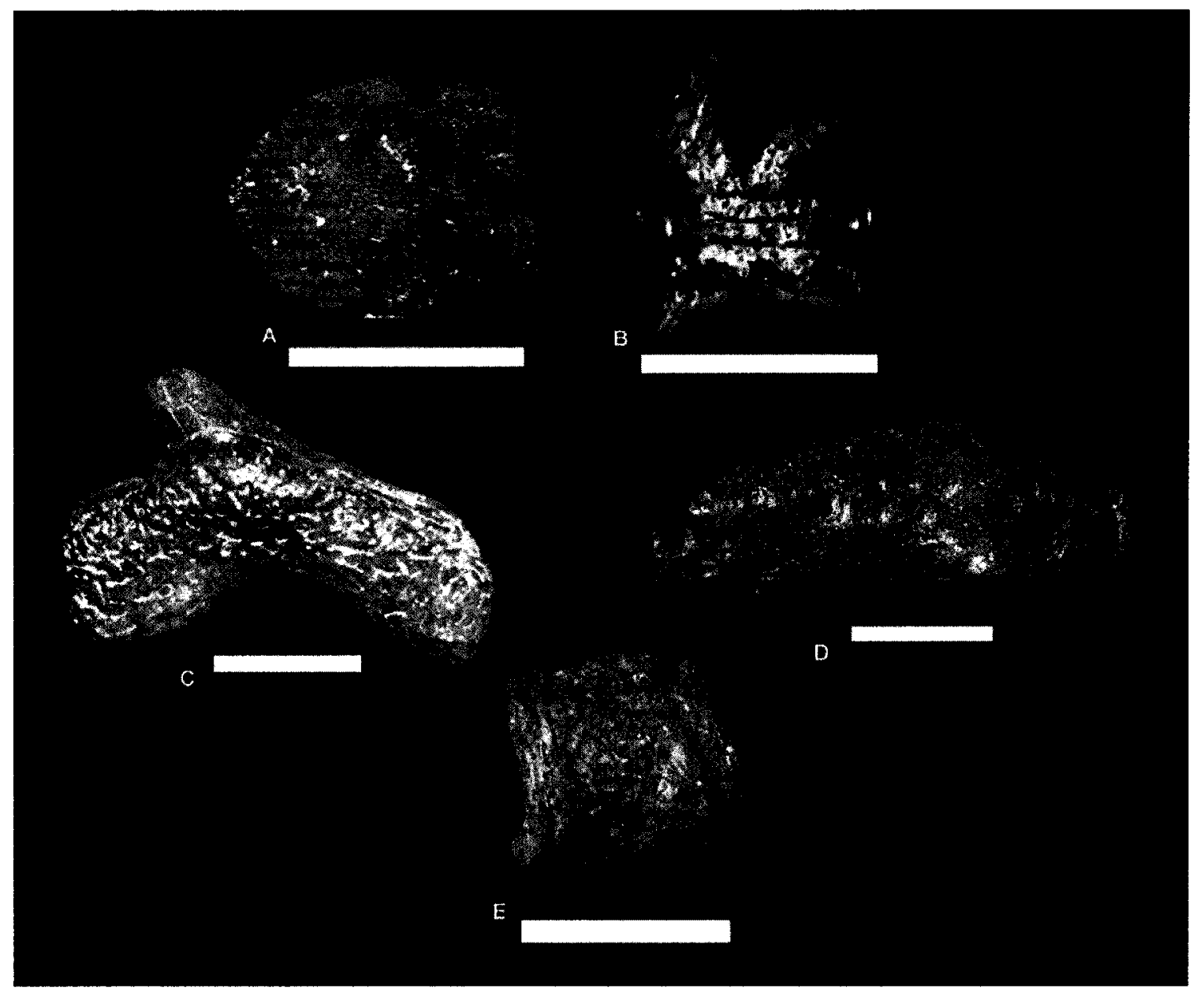

Figure 12: Representative examples of the abrasion stages used to score vertebratederived elements from the Van der Voort and Bainbridge River (BR-3) localities for the comparative taphonomic census. (A) Stage 0 - Very angular; (B) Stage 1 - Subangular; (C) Stage 2 - Subrounded; (D) Stage 3 - Rounded; (E) Stage 4 - Very rounded 
sample, while only accounting for $2.24 \%$ of the Bainbridge River (BR-3) sample. Meanwhile, Bainbridge River (BR-3) contained proportionately more elements scoring $1.5,2$, and 2.5 than the Van der Voort sample, by differences of $9.65 \%, 6.44 \%$, and $3.25 \%$ respectively (Table 4 ).

Diversity

Both the Van der Voort and Bainbridge River (BR-3) samples were found to be dominated by bones and bone fragments which could not be identified to element ('Indeterminate bones \& fragments' in Fig. 13) and which therefore could not be assigned any particularly specific taxonomic classification. In fact, only 83 out of 1707 (or $4.86 \%$ ) of the vertebrate fossils (bones, teeth, and their fragments) recovered from the Van der Voort sample were identified to Order or other less inclusive taxonomic ranking (with the Bainbridge River (BR-3) sample scoring slightly higher with 145 out of 1600 , or $9.06 \%$, of vertebrate fossils identified to Order or other less inclusive taxonomic ranking). The relatively small number of elements which were identifiable an ordinal taxonomic level or lower made statistical integration of the taxonomic data difficult. The majority of the elements that fall into the 'Indeterminate bones \& fragments' category most closely resemble elements of osteichthyan derivation (though a small portion of the indeterminate material from the Bainbridge River (BR-3) sample is decidedly more "reptilian"-looking). Once this is taken into consideration, the distribution of recovered elements from both samples is overwhelmingly dominated by osteichthyan remains (Fig. 14). Chi-square test comparisons of these distributions revealed that they are significantly different, with the distribution corrected for the largely osteichthyan 'indeterminate bones \& fragments' (Fig. 10) being only very slightly less significant (Table 5). A complete 


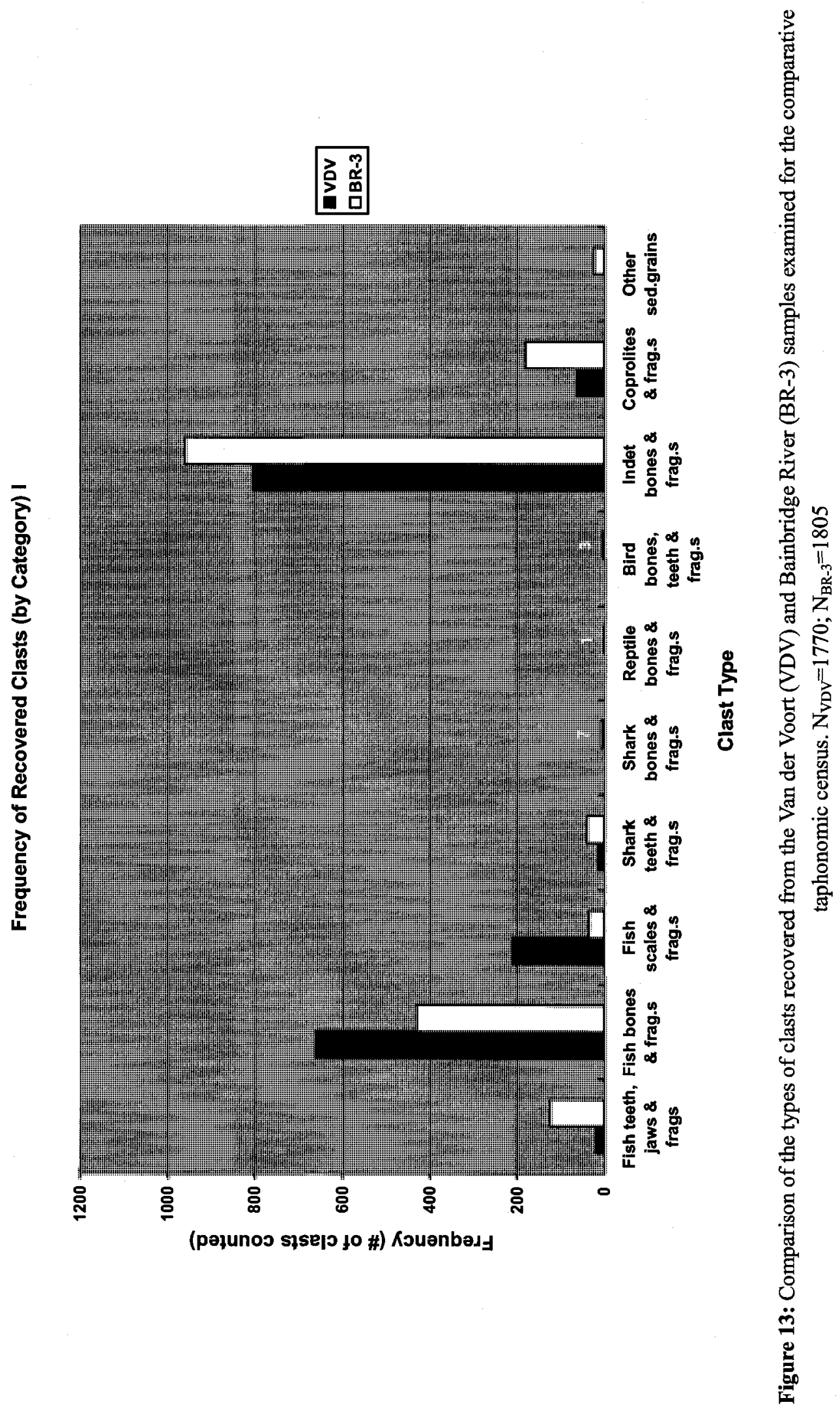




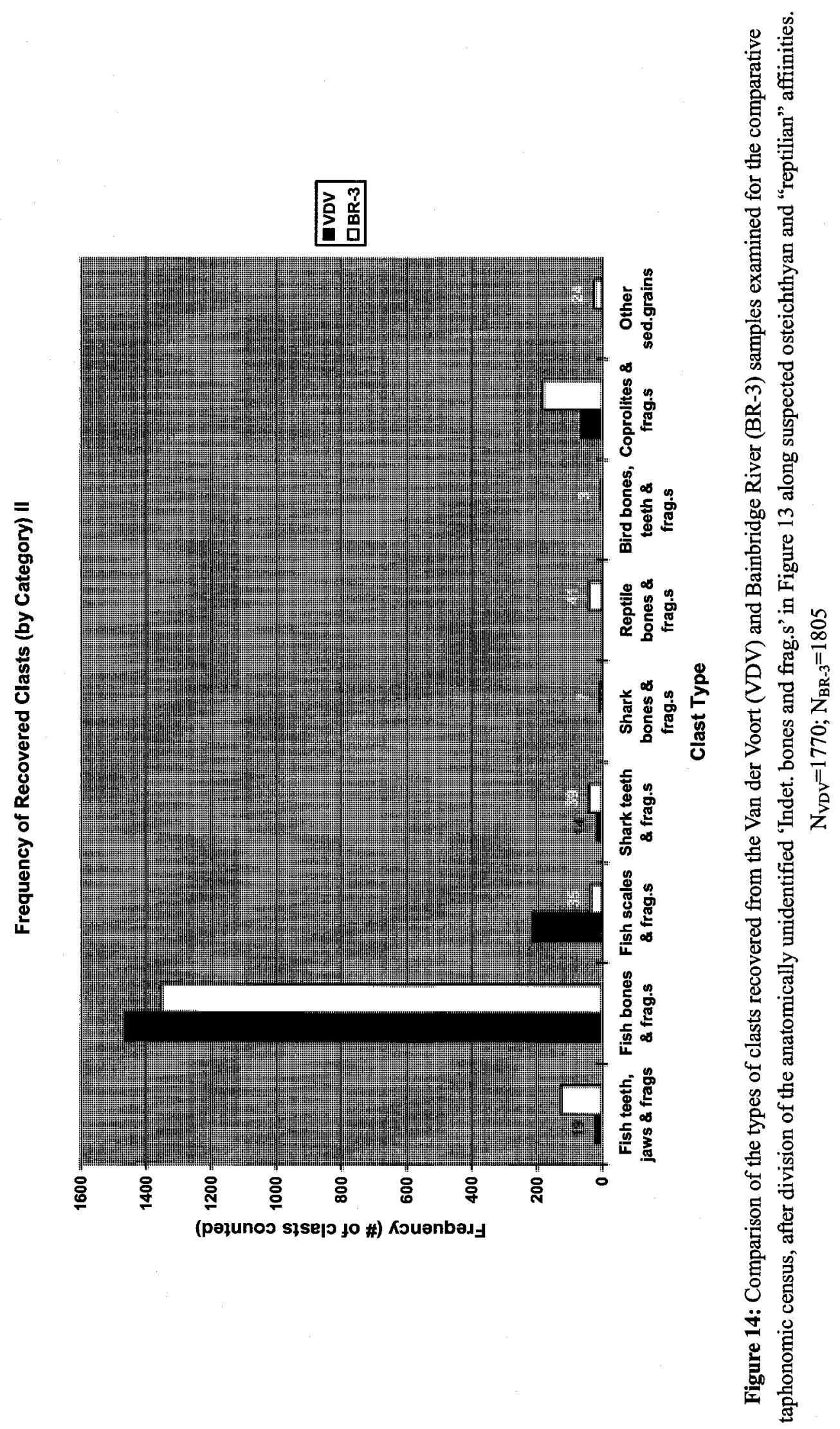




\begin{tabular}{|c|c|c|c|c|c|}
\hline \multicolumn{6}{|c|}{ Statistical Comparison of Distribution of Recovered Clasts } \\
\hline $\begin{array}{c}\text { Comparison of } \\
\text { Proportions of Clasts I }\end{array}$ & $\mathrm{N}=1770$ & $\mathrm{~N}=1805$ & 10 & 367.98 & $6.05 \mathrm{E}-73$ \\
\hline $\begin{array}{c}\text { Comparison of } \\
\text { Proportions of Clasts II }\end{array}$ & $\mathrm{N}=1770$ & $\mathrm{~N}=1805$ & 9 & 351.02 & $3.75 \mathrm{E}-70$ \\
\hline
\end{tabular}

Table 5: Statistical comparison via Chi-square tests of the distribution of the clasts recovered from the Van der Voort (VDV) and Bainbridge River (BR-3) samples used for the comparative taphonomic census. The column " $p$ (same)" indicates the probability that the distribution curves from the two samples are the same. 
listing of the clasts recovered from the $0.841 \mathrm{~mm}$ and $1.68 \mathrm{~mm}$ sieve fraction samples used in the comparative taphonomic census can be viewed in full in Appendix II.

\section{Summary}

In summary, the vertebrate remains preserved in the Van der Voort sample exhibit signs of significant sorting (by shape and by size) and abrasion. The Bainbridge River (BR-3) sample against which the Van der Voort sample was compared also exhibits signs of significant sorting and abrasion, the difference being that the Bainbridge sample is statistically somewhat skewed towards slightly larger elements, slightly fewer plateshaped elements, and heavier abrasion. Overall, the composition of both bioclastic concentrations are both dominated by bony fishes and sharks, while the Bainbridge River sample has the greater concentration of tetrapod remains. Though a statistical comparison of taxonomic diversity is impractical, it can be qualitatively noted that overall the taxonomic composition of the ichthyofauna of these two deposits are similar, but differing in abundance. In terms of tetrapod diversity the Bainbridge River sample contained taxa which were not found at the Van der Voort locality, specifically of plesiosaurs and birds. The paleoecological and paleoenvironmental implications of these findings will be discussed below.

\section{Petrographic Analysis}

In order to interpret varying diagenetic processes affecting Late Cretaceous bioclastic accumulations along the Manitoba Escarpment, thin sections from five bioclastic accumulations were analyzed to assess similarities and differences in the diagenetic histories of these deposits. These included samples from the Van der Voort 
Farm, Carrot River (DH-1), Thunder Hill and two localities along the Bainbridge River (BR-1 and BR-3).Complete listings of the results of the electron microprobe analyses can be view in Appendix III, and a summary of the petrographic and sedimentological observations can be seen in Table 6.

Van der Voort

Overall grain size at the Van der Voort sample is typically small (0.3 to 0.7 millimetres) and the sample is moderately well sorted, though the phosphatic bioclasts tend to be larger $(0.5$ to $1.5 \mathrm{~mm})$. The lithology at this locality is unique compared to those seen in any of the other samples examined (Fig. 15). Petrographically, this material is classified as a biosparite with a wackestone to packstone texture, wherein clasts consist primarily of inoceramid-derived prismatic calcite and vertebrate-derived, phosphatic bioclasts preserved amidst pervasive, sparry calcite cement. These lithologies are therefore further classifiable as "inoceramites", as per Hattin (1975). Contacts between bioclasts are mostly point contacts, though some are relatively long relative to the size of the grains, and grains showing breakage or signs of plastic deformation were rare. Sedimentologically, point count analysis reveals that the sample consists of approximately $96.8 \%$ calcite (approximately 53\% sparry calcite cement and $43.8 \%$ inoceramid prisms), while phosphatic bioclasts account for only about $2.6 \%$. These phosphatic bioclasts include mainly tabular and/or spindle-shaped vertebrate bone and tooth fragments, with occasional ovoid-shaped pellets (some of which are recognizable as coprolites). The remainder is divided between small quantities of siliciclastic (quartz) grains (approximately $0.2 \%$ ) and argillaceous (possibly smectite clay) minerals (approximately $0.4 \%$ ). 


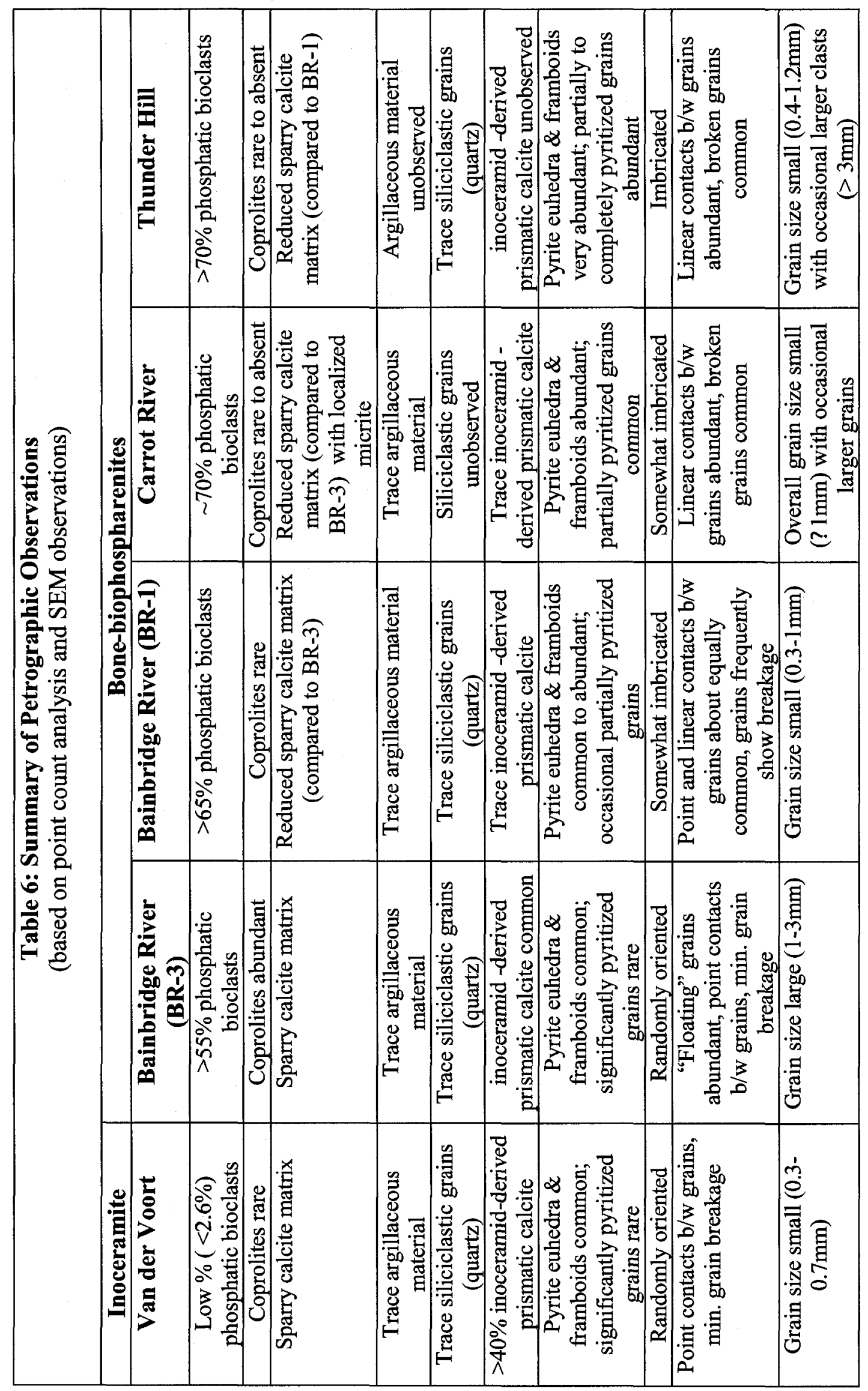



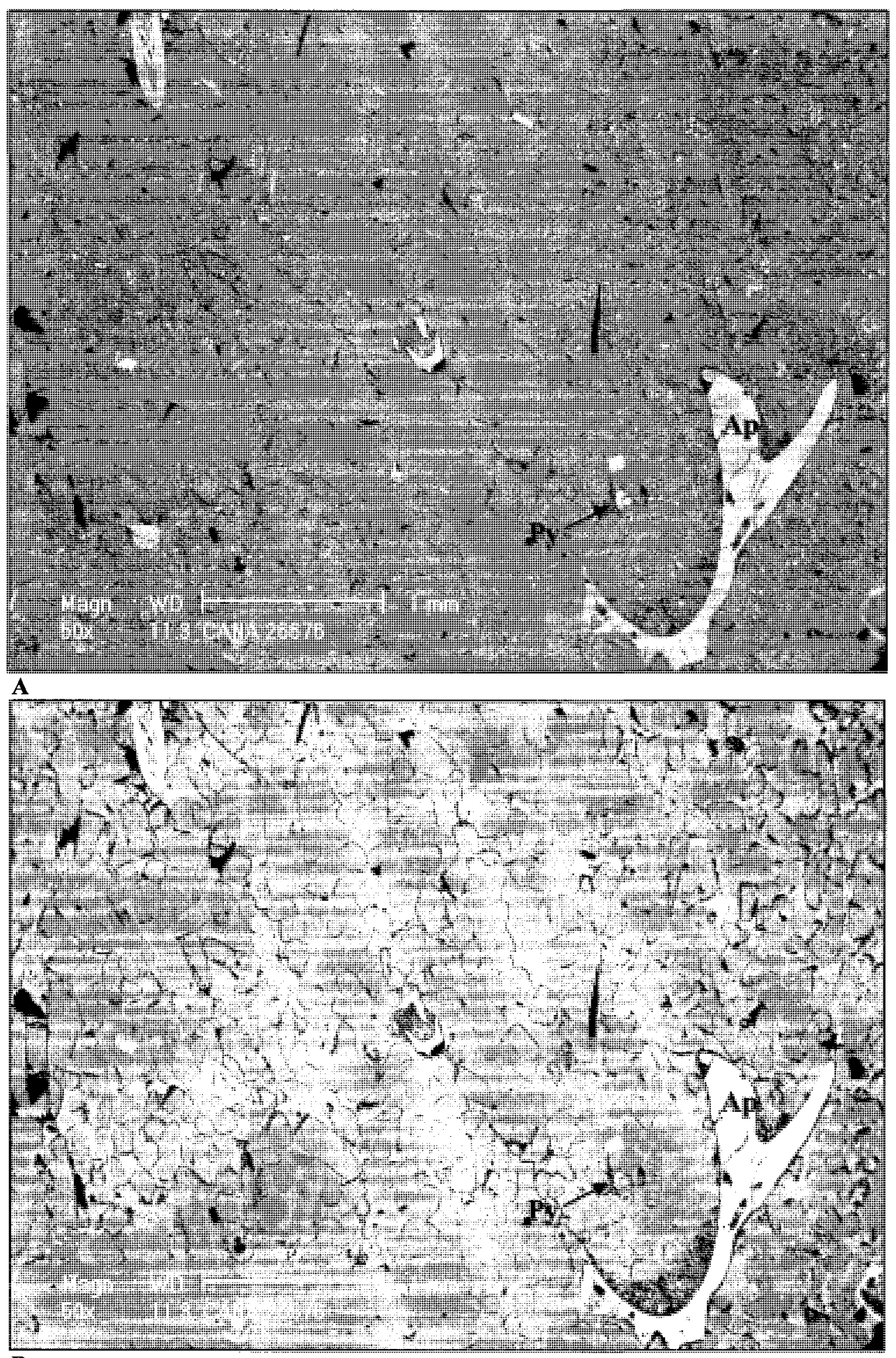

B

Figure 15: Representative SEM images of thin section material from the Van der Voort Farm. Low contrast (A) and higher contrast (B) general views of calcite-cemented wackestone to packstone with pervasive inoceramid-derived prismatic calcite. In (A) and (B), pyrite (Py) can be seen as small white flecks, while vertebrate bone (Ap) appears much brighter in (B) In (B), prismatic calcite can be distinguished as slightly darker colored than the lighter sparry calcite cement surrounding it. 
Not counted in the point count analysis but relatively common in the sample are small $(\leq 5 \mu \mathrm{m})$ pyrite euhedra as well as framboidal pyrite (Fig. 16a). Where present, pyrite occurs most frequently within grains of the prismatic calcite, somewhat rarely within the intragranular pore spaces of phosphatic clasts (though rarely within or replacing the apatite itself), and was absent within the sparry calcite cement.

Higher contrast SEM images highlight the difference between the inoceramidderived prismatic calcite and the sparry cement of the matrix, and under higher magnification the hexagonal cross-sectional form of the prisms is readily apparent (Fig. 16b). Electron microprobe analysis of the two calcites confirms the difference in brightness in the SEM images is largely due to differing amounts of iron; where the inorganically precipitated calcite cement is relatively rich in iron compared to the biologically derived prismatic calcite (Appendix III).

Bainbridge River (BR-3)

The sample appears relatively well sorted, with grain sizes typically ranging between one and three millimetres (the largest average grain size of any of the samples examined). In contrast to the Van der Voort material, thin-sectioned material from the Bainbridge River (BR-3) locality examined petrographically classifies as bone-biophospharenite (Fig. 17). It possesses a coarse grainstone to rudstone texture and pervasive sparry calcite cementation, with calcite cement accounting for approximately $39.4 \%$ of the thin-section sample examined. Phosphatic clasts appear largely "afloat" in the calcitic matrix, and include tabular, spindle, and ovoid shaped phosphatic bioclasts representing principally fish bones, fish and shark teeth, as well as coprolites; accounting together for 

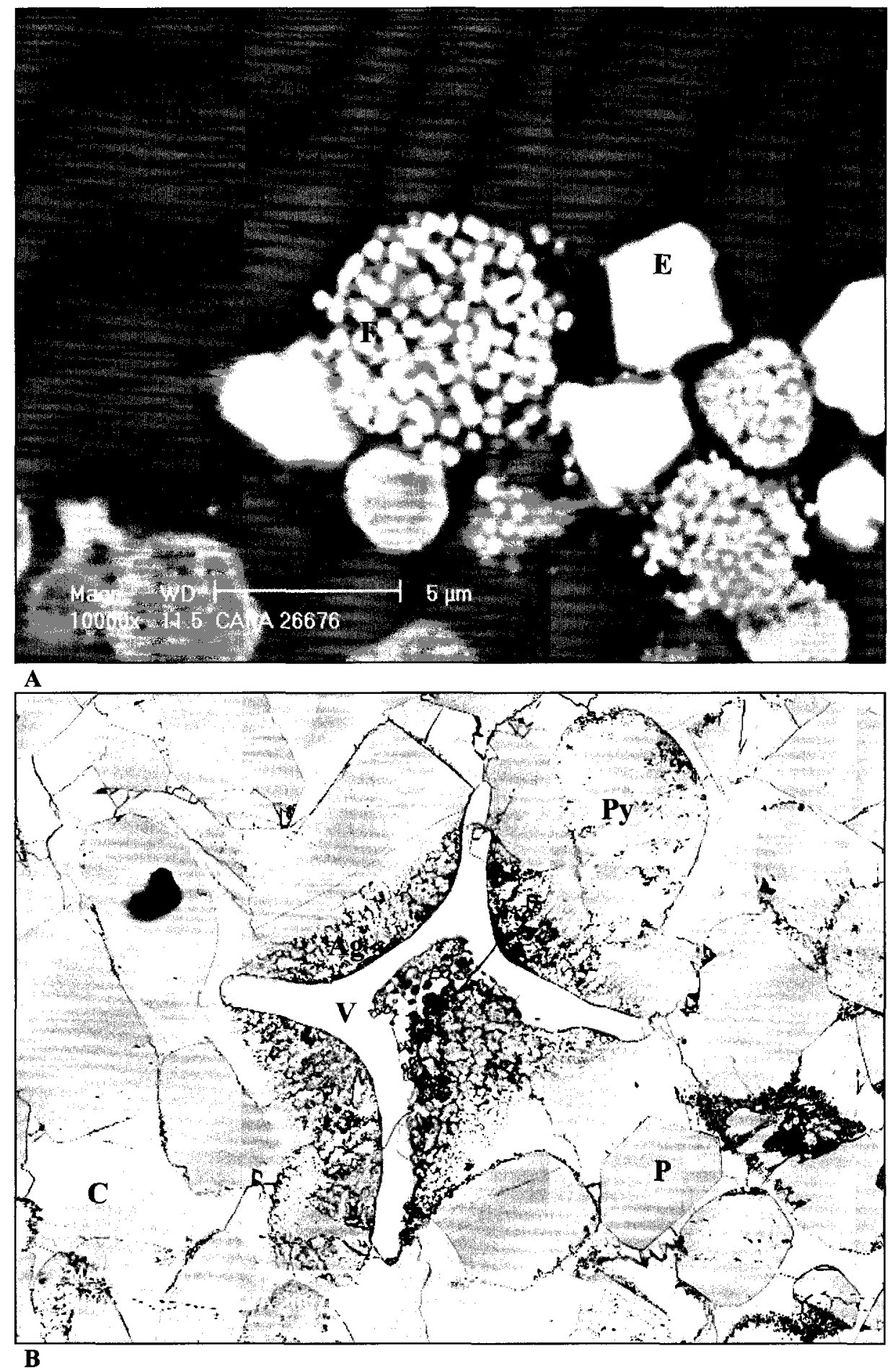

Figure 16: SEM images of thin section material from the Van der Voort Farm. (A) Framboidal (F) and euhedral (E) pyrite under high magnification. (B) Higher magnification high contrast view, highlighting the difference between sparry calcite cement $(\mathrm{C})$ and inoceramid-derived prismatic calcite $(\mathrm{P})$. Pyrite (Py) is visible as small white flecks, and the darker, rough-textured area in the centre of the photograph is argillaceous material $(\mathrm{Ag})$. Also visible is the characteristic hourglass form of a fish vertebra (V). 


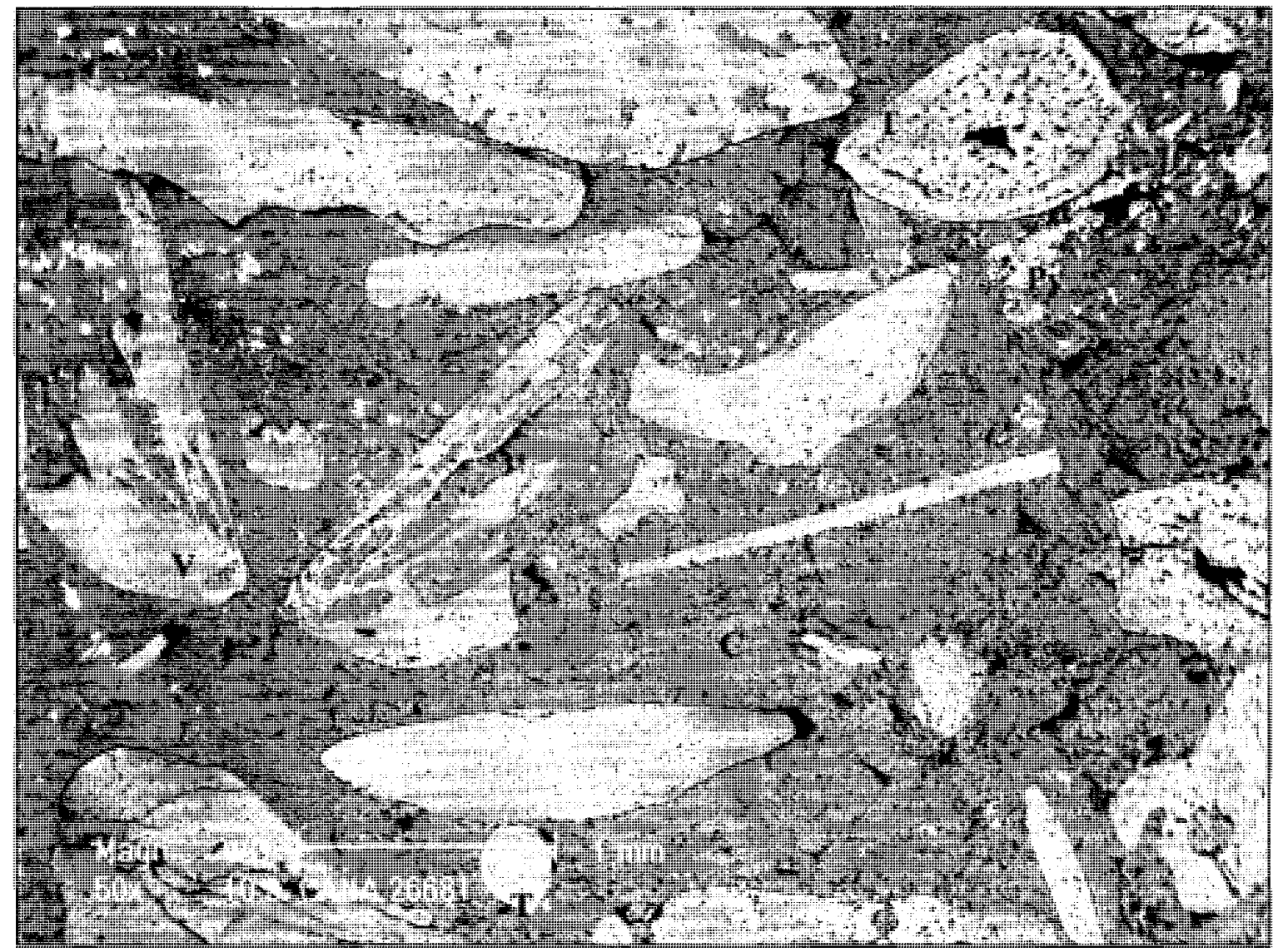

Figure 17: Representative SEM image of thin section material from the Bainbridge River (BR-3). General view of calcite-cemented (C) bone-biophospharenite with a coarse grainstone to rudstone texture. Apatitic bone and tooth fragments visible here include a fish vertebra (V) and fish teeth (T). Also visible is some pyrite as small white flecks (Py). 
approximately $57.4 \%$ of the sample. Inoceramid-derived prismatic calcite was commonly visible in SEM microphotographs (Fig. 18), and in one region a set of "articulated" prisms was observed (Fig. 19a). Inoceramid-derived prismatic calcite was more difficult to discern using optical petrographic techniques, however, was relatively rare (approximately $2.6 \%$ ) in the point count analysis. Electron microprobe analysis confirms that the differences between the two varieties of calcite in this sample is consistent with what was seen between inoceramid-derived prismatic calcite and inorganically precipitated calcite spar in the Van der Voort sample (Appendix III). Once again, argillaceous material and siliciclastic grains are rare to absent.

Small pyrite euhedra and framboids were observed commonly in the sample and, where present, they appear to occur primarily in and around inoceramid-derived prismatic calcite crystals and coprolites (e.g. Figs. 18, 19b). Pyrite was also observed, though less frequently, within intragranular pore spaces (e.g. dental pulp cavities). Where articulated inoceramid prisms were observed, they were virtually pyrite-free.

Bainbridge River (BR-1)

Another bone-biophospharenite thin section examined for this study comes from a second locality along the Bainbridge River (BR-1), which is texturally classifiable as a grainstone cemented by sparry calcite crystals (Fig. 20). Compared to BR-3, this sample is more poorly sorted, with grain sizes ranging between approximately 0.3 and one millimetre in length. Linear contacts between grains are more common here than in BR-3, and broken grains are common. Relative to BR-3, BR-1 contains a higher concentration of phosphatic bioclasts (approximately 67.8\%) and somewhat less calcite cement (approximately $31.4 \%$ ). Phosphatic bioclasts are predominantly spindle-shaped, 

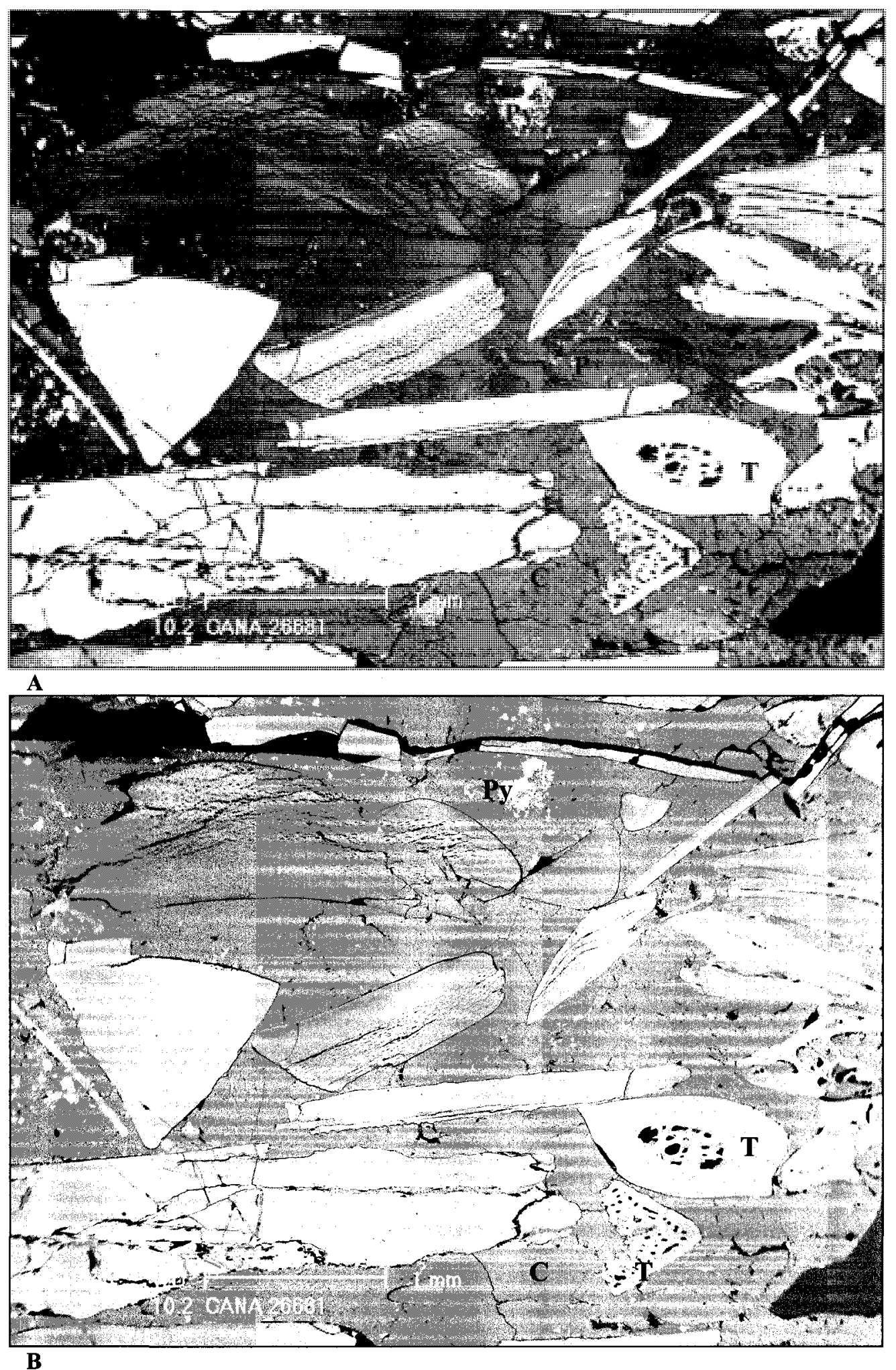

Figure 18: SEM images of thin section material from the Bainbridge River (BR-3). High contrast (A) and lower contrast (B) general views of calcite-cemented (C) bone-biophospharenite with a coarse grainstone to rudstone texture. Pyrite $(\mathrm{Py})$ is visible as white flecks and identifiable vertebrate fragments include teeth $(\mathrm{T})$. Some calcite, consistent with inoceramid-derived prismatic calcite $(\mathbf{P})$, is also visible in $(\mathbf{A})$, being slightly darker than the calcite surrounding it. 

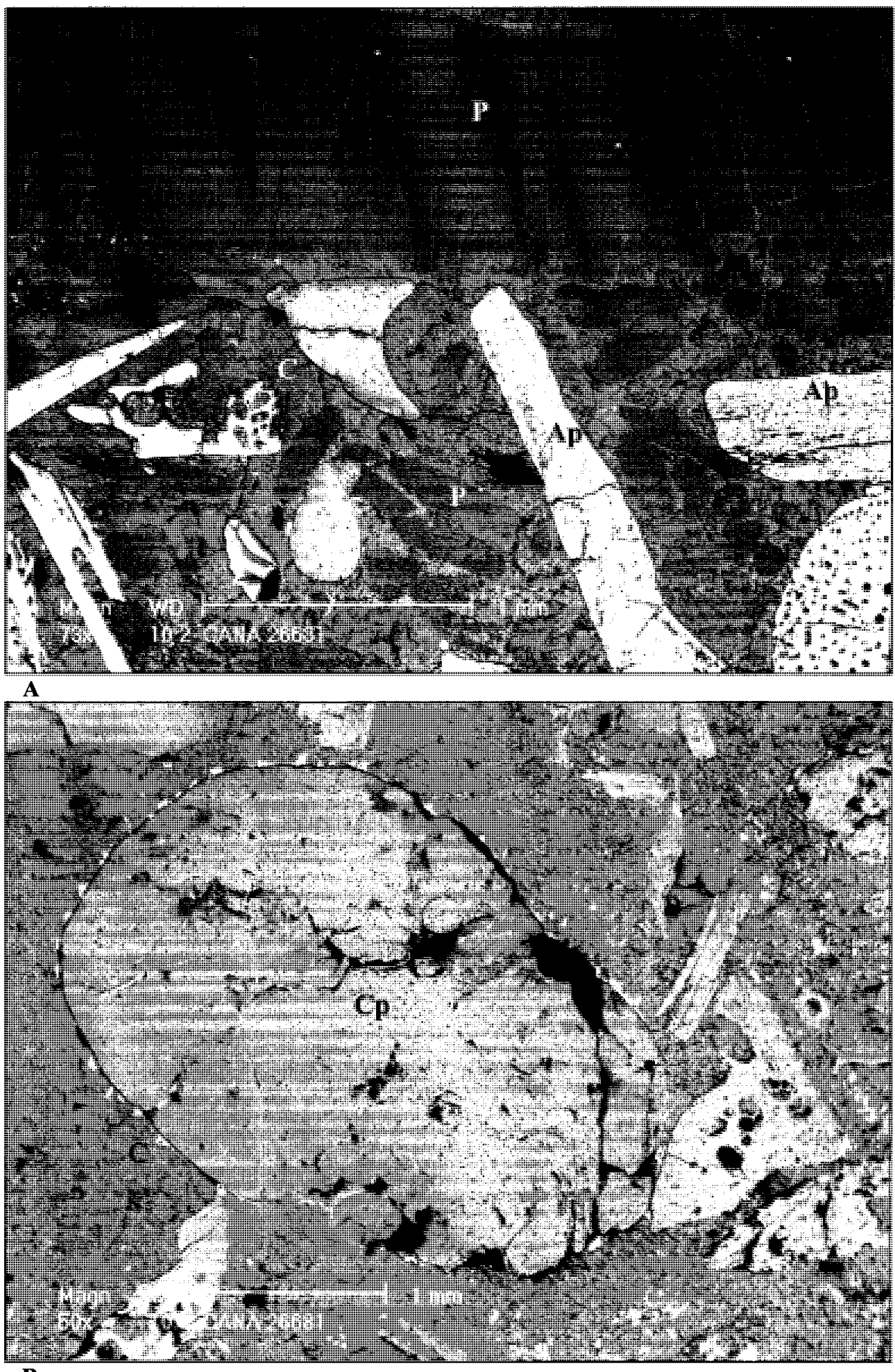

B

Figure 19: SEM images of thin section material from the Bainbridge River (BR-3). (A) High contrast image highlighting a region of 'articulated' inoceramid prisms (P). Calcite-cemented (C) and vertebrate bioclasts (Ap) are also visible. (B) Clusters of pyrite (visible as small white flecks) occurring around and within a coprolite $(\mathrm{Cp})$ surrounded by calcite cement $(\mathrm{C})$. 


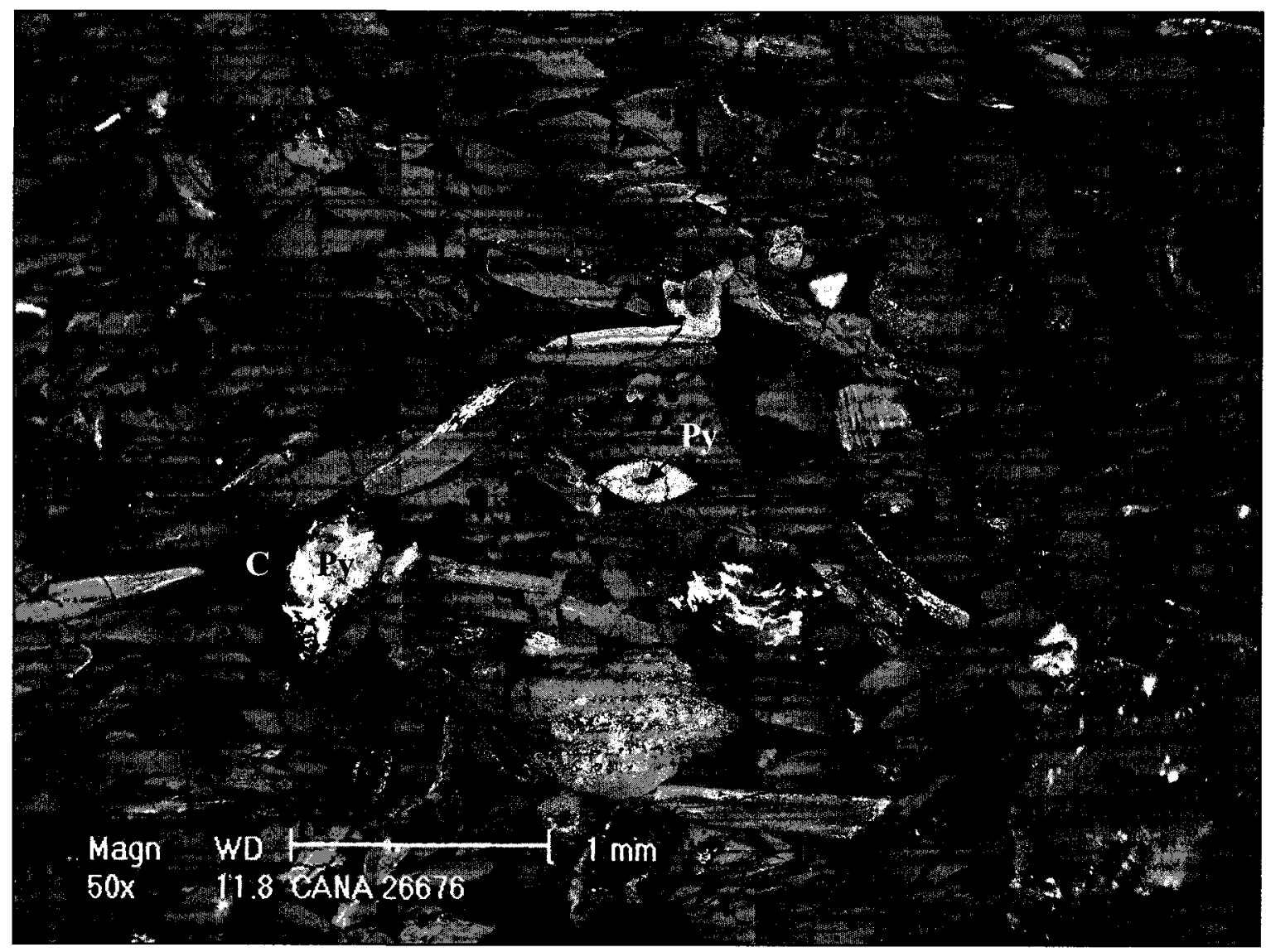

Figure 20: Representative SEM image of thin section material from the Bainbridge River (BR-1). General view of calcite-cemented (C) bone-biophospharenite with a grainstone texture. Apatitic bone and tooth fragments (Ap) are abundant, and include some partially pyritized elements (Py). 
with occasional tabular- or ovoid-shaped clasts, and consist largely of bone and tooth fragments with only rare coprolites.

Inoceramid-derived prismatic calcite is very rare, accounting for only one out of five hundred points counted (or $0.2 \%$ ). Pyrite is more common here than in any of the previous samples, and occurs predominantly as euhedral crystals with rarer framboids within the intragranular space of porous phosphatic bioclasts, and in some cases euhedra displace the apatite outright (Fig. 21), where some clasts are nearly entirely pyritized. Electron microprobe analysis confirms that the differences between the two varieties of calcite in this sample is consistent with what was seen between inoceramid-derived prismatic calcite and inorganically precipitated calcite spar in the Van der Voort sample (Appendix III).

Carrot River (DH-1)

The thin section of the sample collected at a locality along the Carrot River (DH-1) is yet another bone-biophospharenite with a calcareous matrix (sparry calcite, approximately $29 \%$ of the sample) that is dominated by mostly spindle-shaped phosphatic debris, primarily fish bones and teeth (phosphatic debris accounts for approximately $69.4 \%$ of the sample) (Fig. 22a). The sample is moderately sorted, with an average grain size of approximately one millimetre or smaller, but with occasional larger grains (Fig. 22b). The concentration of phosphatic bioclasts in this grainstone is noticeably higher than that observed in the BR-1 sample, and there is also comparatively slightly less calcareous cement. The Carrot River sample resembles the BR-1 sample, however, in that coprolites were not readily identifiable, and that linear contacts between bioclasts are quite common, as are broken grains. Inoceramid-derived prismatic calcite 

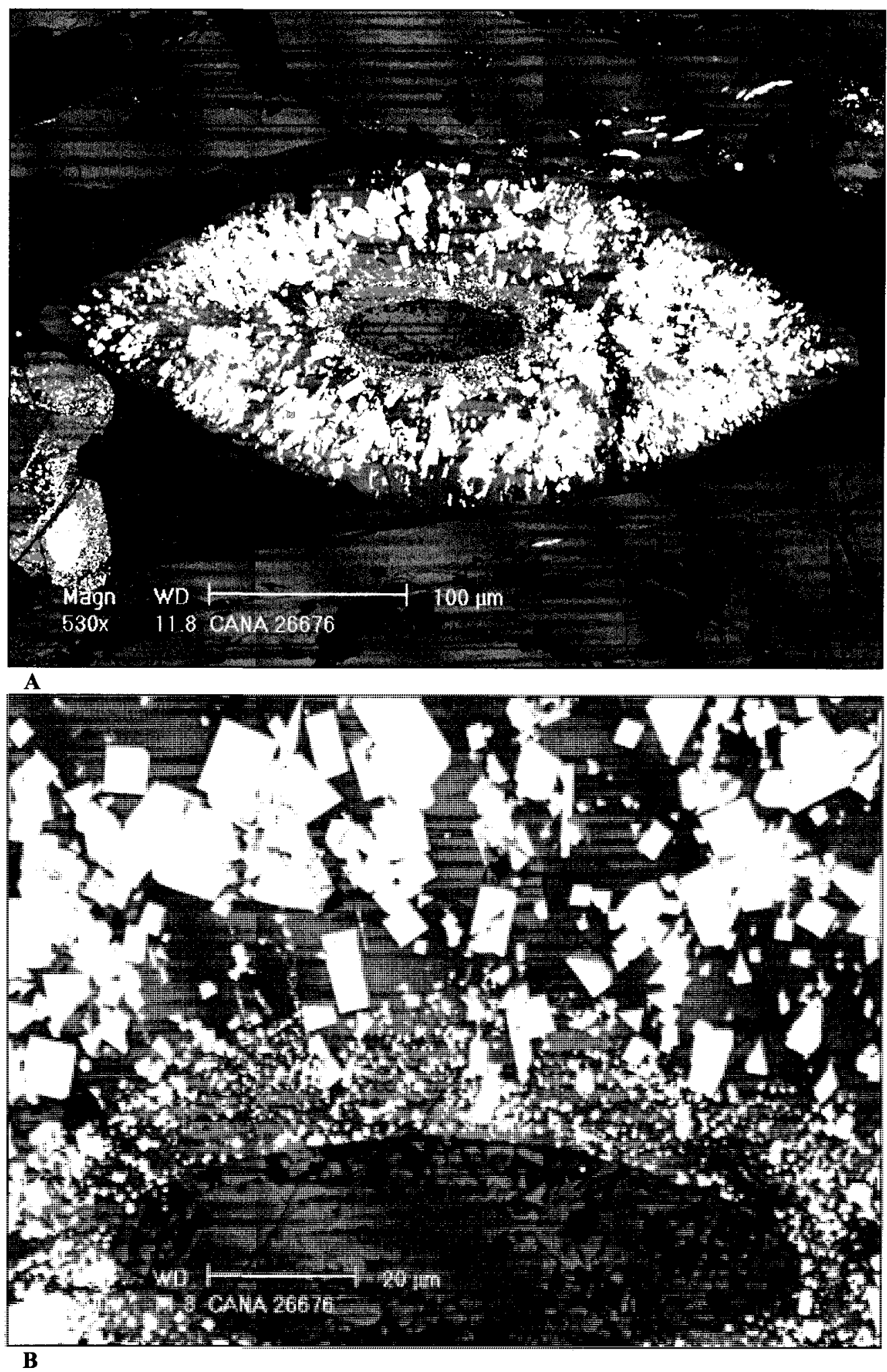

Figure 21: SEM images of thin section material from the Bainbridge River (BR-1). (A, B) Increasingly magnified view of pyrite crystal growth within a fish tooth (this tooth is also visible in the centre of Fig. 20). 

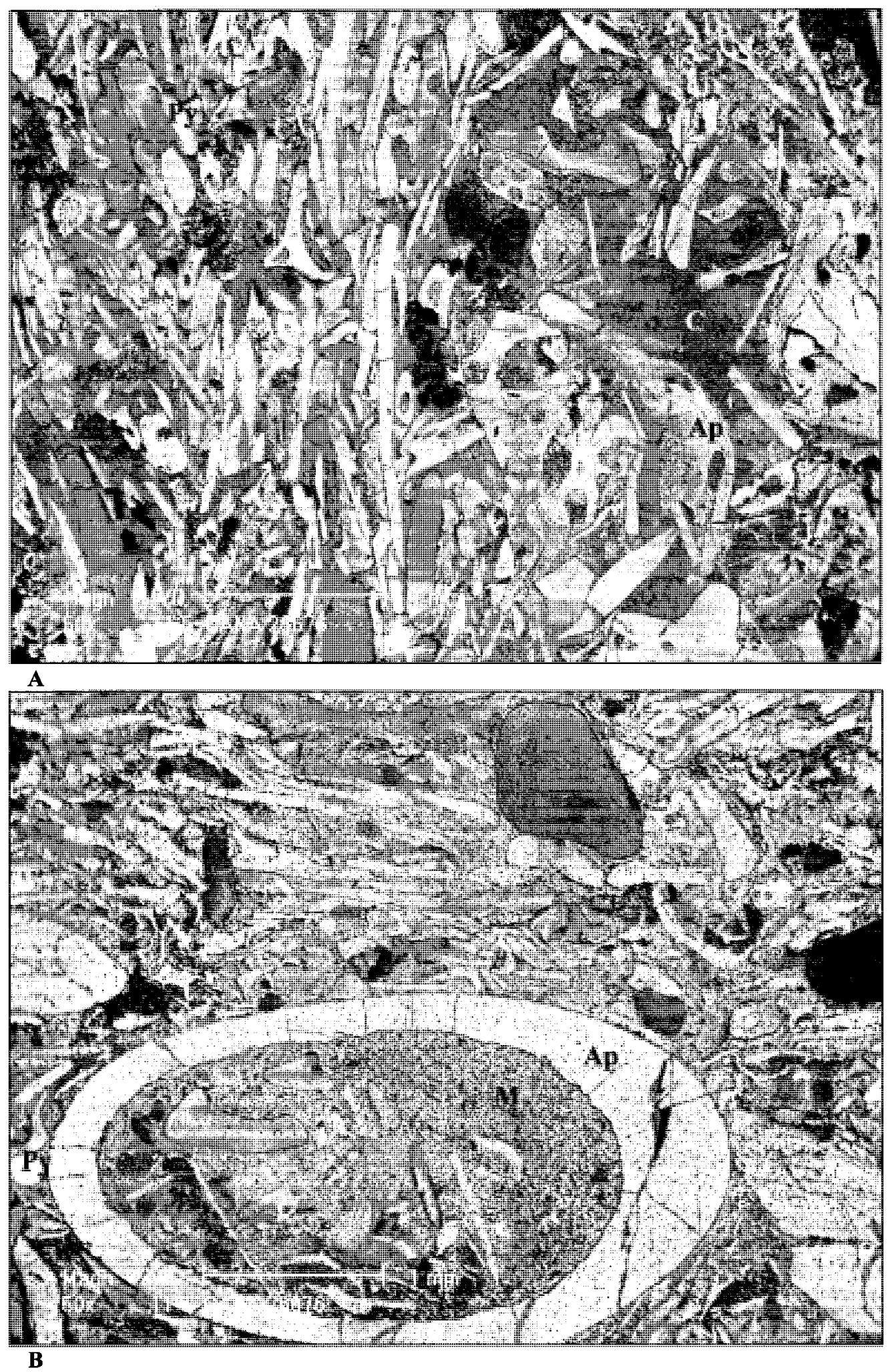

Figure 22: Representative SEM images of thin section material from the Carrot River. (A, B) General views of calcite-cemented (C) grainstone with apatitic bone and tooth fragments (Ap), common partially pyritized bone fragments (Py) and localized micrite cement (M, in B). 
was also present only in trace amounts, with only four potential prisms identified using the petrographic microscope (accounting for approximately $0.8 \%$ of the sample) and few were observed using the SEM. Pyrite is more abundant in this sample than in the previously described samples, and both euhedra and framboids appear clustered within intragranular pore spaces of phosphatic grains, with partially pyritized phosphatic grains also being fairly common. In contrast to the sparry calcite cement seen elsewhere in the sample, some of the few larger bioclasts seem to contain calcareous cement that appears more micritic (e.g. in Fig. 22b).

\section{Thunder Hill}

The bioclastic horizon from the Thunder Hill locality is classified as a bonebiophospharenite with a grainstone texture. The sample is moderately sorted, with average grain sizes ranging from approximately 0.4 to 1.2 millimetres, though larger clasts $(>3 \mathrm{~mm})$ occasionally occur locally. It is composed primarily $(73.4 \%)$ of spindleand tabular-shaped phosphatic bioclasts, specifically fish bones and teeth (coprolites were not observed), set within a comparatively reduced (26.4\%) sparry calcite matrix (Fig. 23a). Siliciclastic grains were observed in only trace amounts $(\sim 0.2 \%)$, and neither inoceramid-derived prismatic calcite, nor any argillaceous materials were observed.

The phosphatic clasts are very tightly packed within the sample, with linear grain contacts dominating and abundant broken grains (Fig. 23). Pyrite is very abundant, occurring both as framboids and euhedra (Fig. 24a) and principally within the intragranular pore spaces (e.g. Fig. 24b); partially to completely pyrite-replaced grains are abundant. 

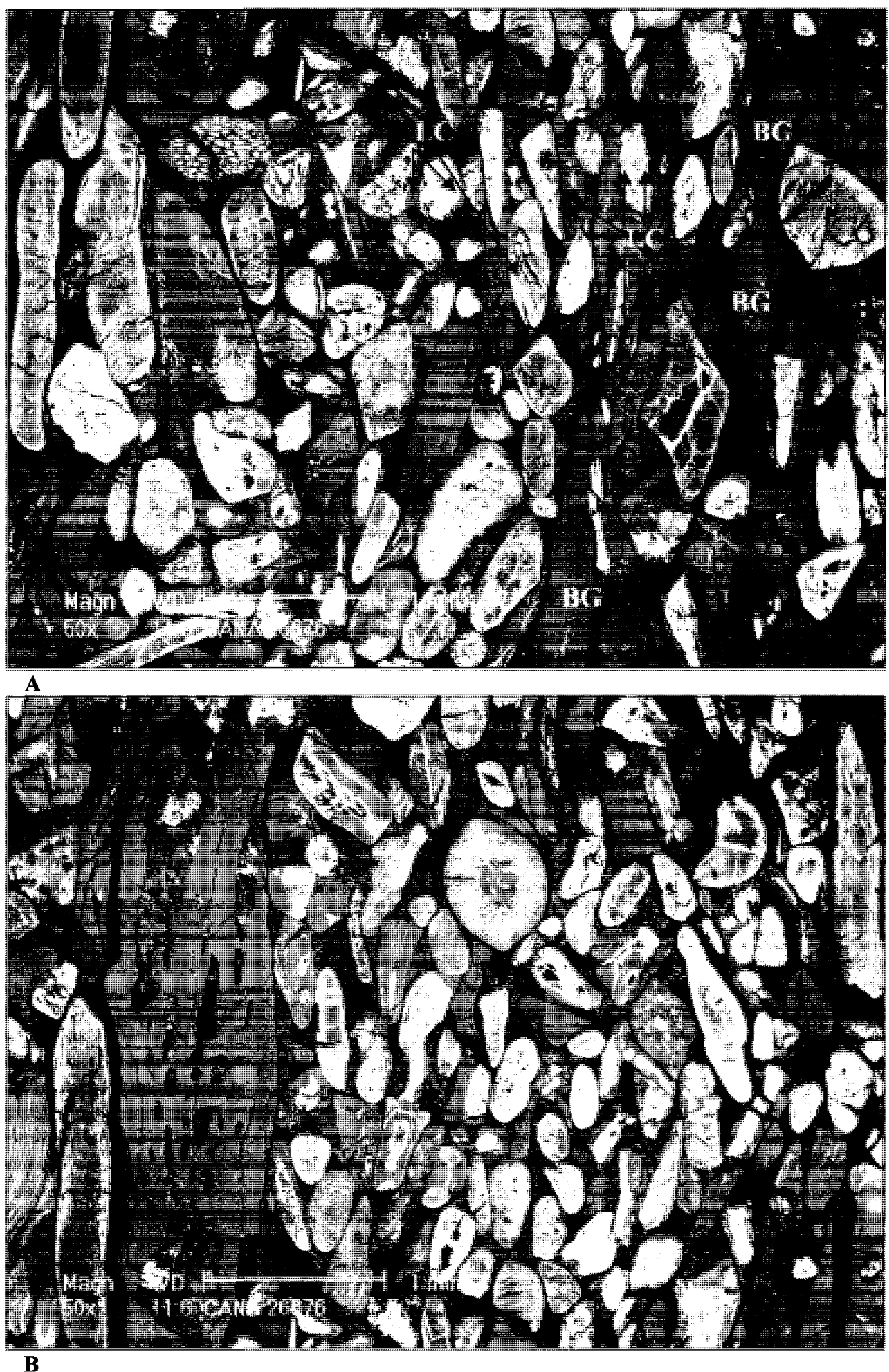

Figure 23: Representative SEM images of thin section material from the Thunder Hill. (A, B) Phosphatic bioclasts are tightly packed within a reduced calcite matrix; pyritized bone and tooth fragments are abundant. (LC) shows linear grain contacts, (BG) shows broken grains. 

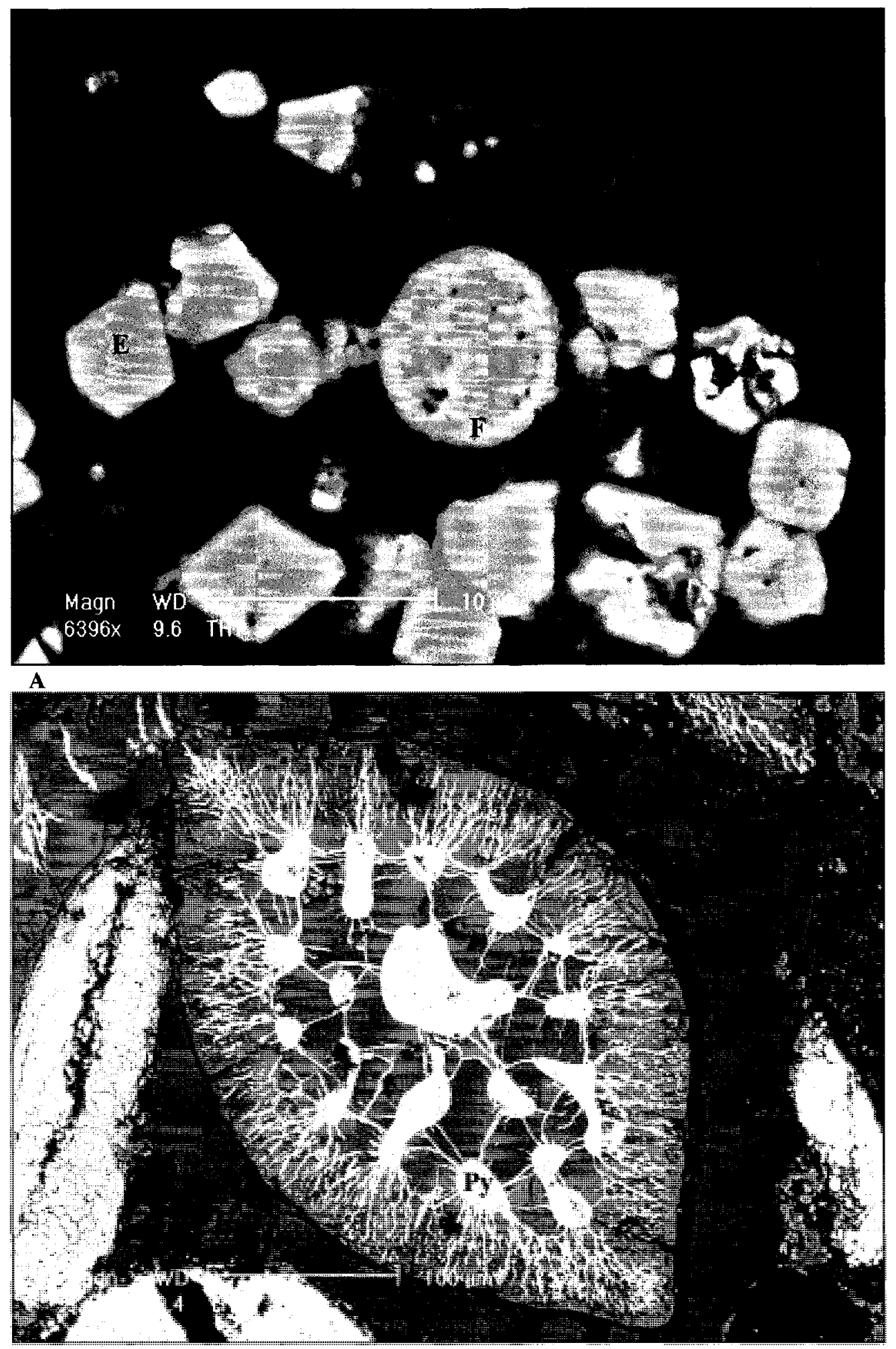

B

Figure 24: SEM images of thin section material from the Thunder Hill. (A) Pyrite occurs as both framboids (F) and euhedra (E). (B) Pyrite (Py) completely filling the internal pore space of a fish tooth $(\mathrm{T})$, surrounded by calcite cement $(\mathrm{C})$. 
Though the Van der Voort inoceramite sample differs significantly from the other samples in terms of lithology, it still displays many of the same diagenetic features and so it can be compared to the diagenetic histories of the bone-biophospharenites. The discussion below will explore how these inoceramites can be potentially viewed as one end of a diagenetic spectrum displayed by bioclastic horizons from the Manitoba Escarpment. 


\section{DISCUSSION}

\section{Biostratigraphy}

Biostratigraphic placement of the inoceramite at the Van Der Voort locality is problematic due to its isolated occurrence without a measurable section that can be sampled for biostratigraphic analysis. The stratigraphic interval of these deposits has to be narrowed then by combining numerous lines of evidence.

The localities nearest to the Van der Voort Farm from which McNeil and Caldwell (1981) describe calcarenitic horizons in outcrop along the Manitoba Escarpment occur along the Vermilion and Wilson rivers, north of Riding Mountain Provincial Park, approximately 76 and $90 \mathrm{~km}$ northwest of the Van der Voort locality, respectively. Along the Vermilion River, McNeil and Caldwell (1981) report calcarenites from outcrop numbers 80,81 and 82 (Fig. 25). These outcrops stratigraphically span from the base of the Morden Shale at the top of outcrop 80, to the lower Belle Fourche Member of the Ashville Formation at the base of outcrop 82 . The calcarenites are reported specifically from the Assiniboine Member of the Favel Formation (in outrcrop 80), as well as from the Belle Fourche Member of the Ashville Formation (in outcrop 82). The calcarenites described from the Assiniboine Member of the Ashville Formation are comprised of the holostratotype of the Marco Calcarenite, a yellowish-brown, thin-bedded deposit composed of fine-grained fragments of bivalve-derived, prismatic calcite. Megafossils are reported to commonly include the belemnoid Actinocamax manitobensis, the bivalves Inoceramus cuvieri (common), Pseudoperna bentonensis (abundant), and abundant calcareous worm tubes of Serpula semicoalita attached to the valves of I. cuvieri (McNeil and Caldwell, 1981). Fish fragments are also reported to be commonly concentrated 


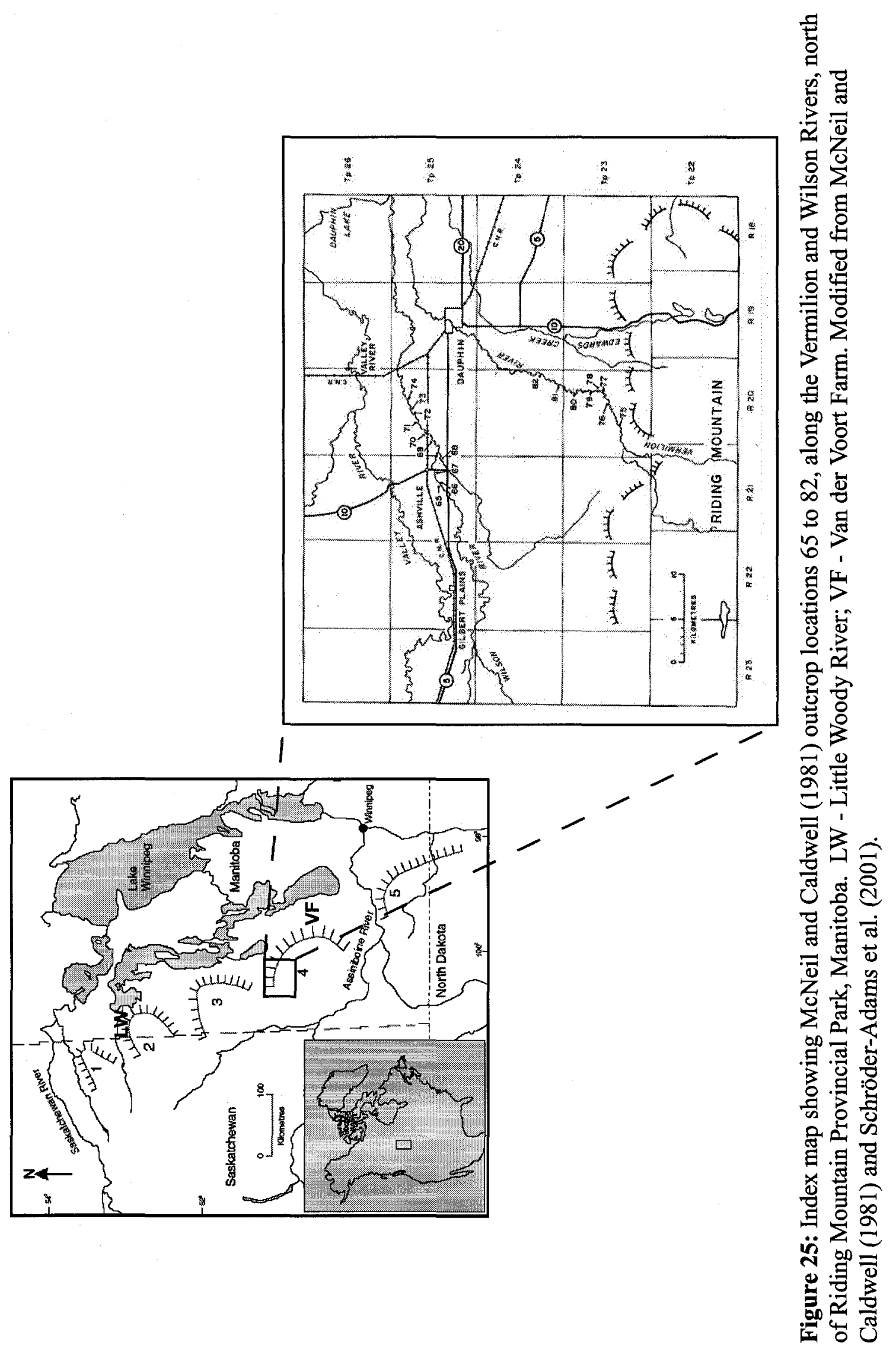


along bedding planes, with rare mosasaur teeth being preserved (McNeil and Caldwell, 1981). Based, however, on the dissimilarity of the megafaunal assemblages, it seems unlikely that the Van der Voort inoceramites represent the Turonian-aged Marco Calcarenite.

Calcarenitic horizons are also described from the Belle Fourche Member of the Ashville Formation, both at locality 82 along the Vermilion River as well as at outcrops 66 through 69 along the Wilson River in the composite type-section of the Ashville Formation (Fig. 25). When comparing the calcarenites of the Belle Fourche Member of the Ashville Formation from along these two rivers, it becomes clear that there are two distinct "sets" to consider. The stratigraphically higher of the two occurs between approximately 11 and 9 metres from the top of the Belle Fourche Member (the Belle Fourche Member measures approximately $27 \mathrm{~m}$ at the composite type-section of the Ashville Formation; McNeil and Caldwell, 1981). This stratigraphically higher calcarenite is found both directly above and below a prominent bentonite horizon, measuring from $0.53 \mathrm{~m}$ in thickness in outcrop 66 to $0.79 \mathrm{~m}$ in thickness at outcrop 82 (McNeil and Caldwell, 1981). This bentonite was interpreted by McNeil and Caldwell (1981) to be the northern continuation of the " $\mathrm{X}$ " bentonite, and the calcarenites straddling it were interpreted as the Ostrea beloiti beds. These calcarenites are described as containing abundant Ostrea beloiti valves that are well indurated, set in a background matrix of very fine to fine calcite prisms, with rare to common fish fragments (McNeil and Caldwell, 1981). Comparison with specimens of the Ostrea beloiti beds collected from Manitoba Escarpment reveal, however, that these beds contain comparatively far more bivalve shells and have a very different appearance from the inoceramites collected 
at the Van der Voort locality (compare, for example, Fig. 26 to Schröder-Adams et al., 2001, Fig. 10a). In fact, these oyster fragments, comprised exclusively of left valves (Haggart, pers. comm.., 2008), have been identified as Ostrea dunveganensis Warren 1930, which differs from specimens of Ostrea beloiti collected from the Bainbridge River locality in that the $O$. dunveganensis valves are consistently more elongate, slender, regularly rounded and thinner than left valves of $O$. beloiti (Haggart, pers. comm., 2008), while $O$. beloiti also exhibits a more curved valve orientation and a more pronouncedly trigonal beak region (Haggart, 2006, G.S.C. Loc. C-307739). These bivalves also help to narrow the biostratigraphic placement of the Van der Voort inoceramites. The type material of $O$. dunveganensis, against which the Van der Voort specimens were compared, originated from the upper part of the Cenomanian Dunvegan Formation of Alberta, and Haggart (2006, G.S.C. Loc. C-307739) states that a Late Cenomanian age is preferred, and considers assignment to the Ashville Formation likely.

The second, and stratigraphically lower "set" of calcarenites from the Belle Fourche Member of the Ashville Formation were "indisputably" recognized by McNeil and Caldwell (1981) as the "fish-scale marker beds"; the eastern stratal equivalent of the Fish Scales Formation of central Saskatchewan and the central plains of Alberta and the basal fish scale-rich bed of the Shaftesbury Formation in the northwestern plains of Alberta. McNeil and Caldwell (1981) reported that the fish scales marker beds occurred within the lowermost six to ten metres, with the upper contact occurring about midway through the Belle Fourche Member. This upper contact was admittedly arbitrary due to the persistence of fish fragments upward through the remainder of the Belle Fourche Member into the overlying Favel Formation and above, however the "sandy and silty sediments 


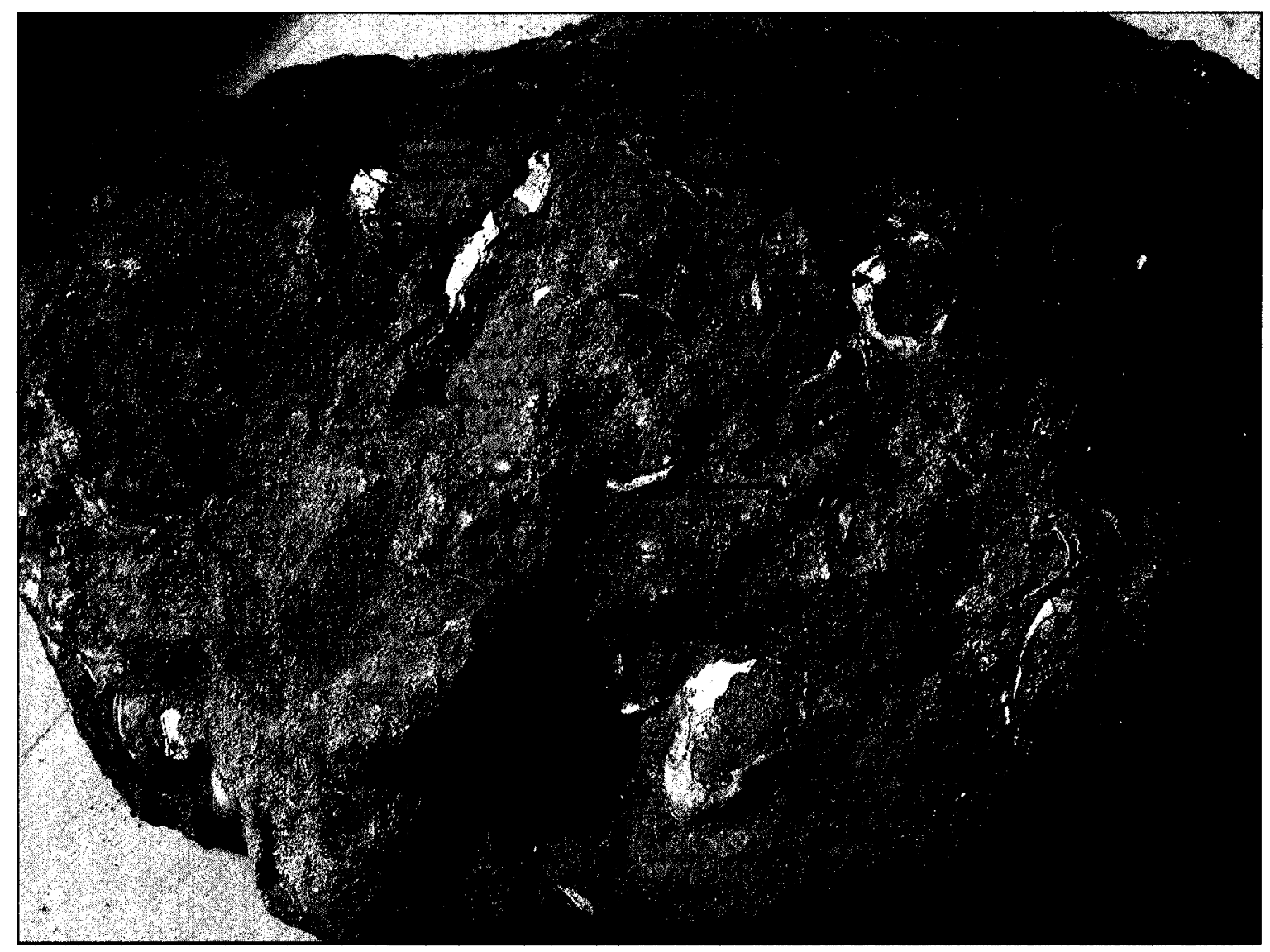

Figure 26: An example of an unprepared sample of Van der Voort Farm inoceramite that was particularly rich in disarticulated oyster valves, identified as Ostrea dunveganensis Warren 1930. Examples of preserved valves are indicated by arrows. 
associated with the fish fragments terminate...at the top of a distinctive, widespread, silty, calcarenitic unit..." (McNeil and Caldwell, 1981). This upper calcarenitic unit is described from outcrops 68 and 69 as being grey in color, weathering to yellowish-orange or light brown, and being comprised of fine-grained calcite, commonly containing fish fragments (McNeil and Caldwell, 1981).

This same calcarenitic unit, occurring about midway through the Belle Fourche Member is also identified in outcrops 40 and 41 along the Little Woody River, just north of the Porcupine Hills, near the Manitoba-Saskatchewan border (Fig. 27). In outcrop 41, McNeil and Caldwell (1981) further describe these calcarenites as: "medium dark grey, weathering medium light grey to light brown; fine to medium grained; composed of calcite prism with fine- to coarse-sized fish fragments common; very hard; lensoid, lenses less than $0.6 \mathrm{~m}$ in length and $5 \mathrm{~cm}$ in thickness; massive to weakly laminated or cross-laminated; orientation of fish fragments is variable but majority parallel lamination...". In this study in situ samples of inoceramites were collected from a locality along the Little Woody River (Fig. 4 and Table 1) approximating McNeil and Caldwell's Outcrop Section 41 (1981). Both the outcrop that was examined, and the inoceramite samples collected there, compared favorably to McNeil and Caldwell's description. Finally, the inoceramite samples collected at the Little Woody River locality were examined briefly in the course of this study for comparison with the Van Der Voort samples, and were found to compare very favorably with the the Van der Voort samples lithologically, sedimentologically and in terms of the composition of the vertebrate fauna. McNeil and Caldwell (1981) also track this mid-member calcarenite in the subsurface immediately to the west of the Manitoba Escarpment using well log data. 


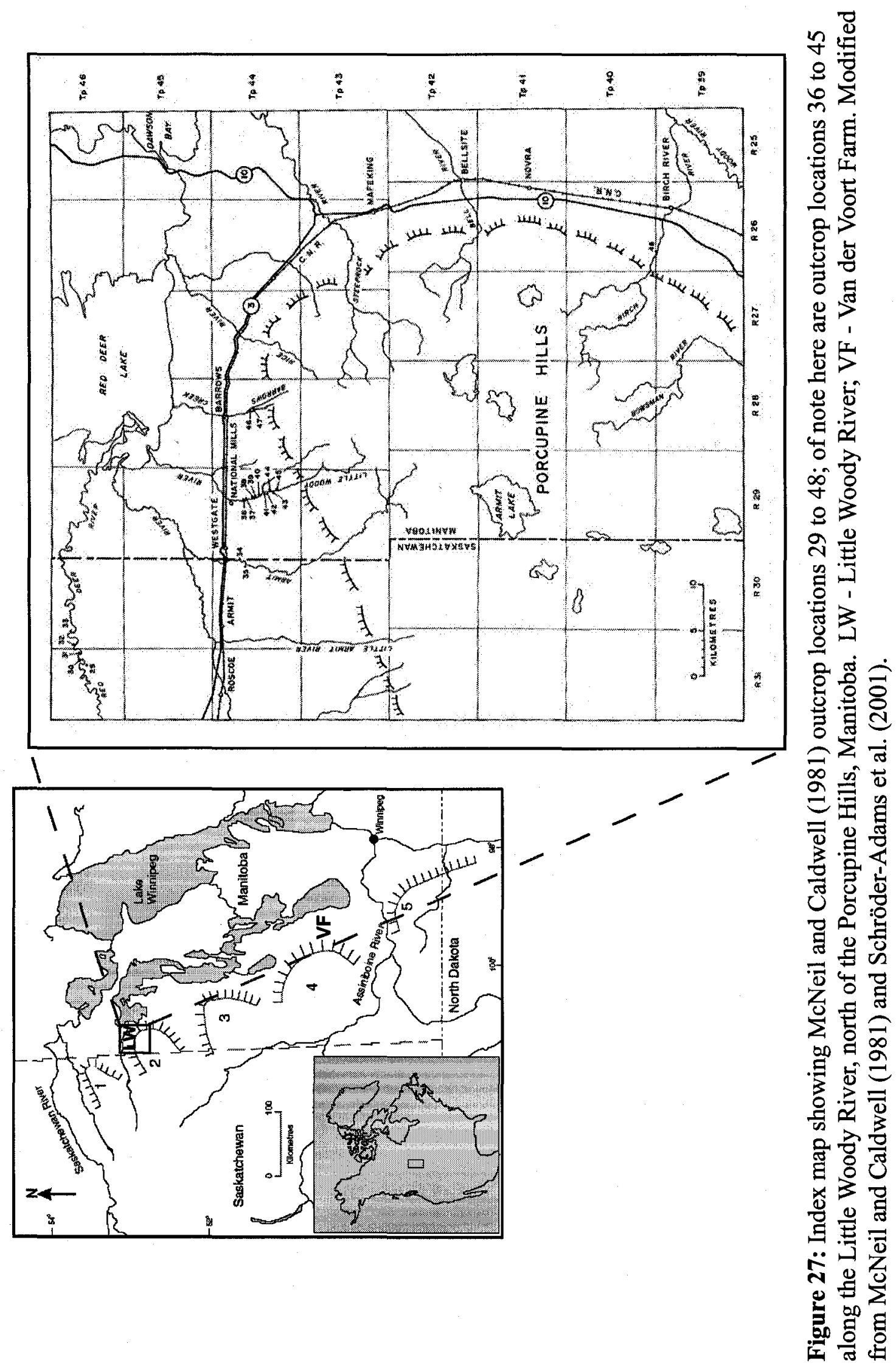


They observed (Fig. 28) that it is only prominent in the northwest (sections B-B' and CC'), and, to a lesser extent, in the southeast (parts of sections G-G' to J-J'), and noted that this distribution corresponded to the areas closest to the escarpment where the Belle Fourche Member is consistently thinner. The log section G-G' matches favorably with the location of the Van der Voort site, and the C-C' section matches favorably with the Little Woody River site.

The vertebrate fauna of the Van der Voort locality also provides some evidence for the narrowing of the biostratigraphic placement of these deposits: for example, Carcharias saskatchewanensis, though originally described (Case et al., 1990) from strata determined to be Early Turonian (Cumbaa and Tokaryk, 1999) in age, has subsequently only ever been found in Cenomanian strata (Shimada and Martin, 1993; Carcharias sp. A of Welton and Farish, 1993; Cicimurri, 2001a; 2001b; Friedman, 2004; Shimada et al., 2006; Cook, 2007). Similarly, Carcharias amonensis, though it may be known as early as the Late Albian (Welton and Farish, 1993), is otherwise also exclusively known from Cenomanian-aged deposits (Welton and Farish, 1993; Cappetta and Case, 1999; Case, 2001; Cicimurri, 2001b; 2004; Antunes and Cappetta, 2002; Vullo et al., 2003; Cumbaa et al., 2006; Shimada et al., 2006; Cook, 2007). Both sharks are common in the Van der Voort deposits, suggesting a Cenomanian age for these deposits. A comparison of the marine vertebrate fauna of the Van der Voort inoceramites in its entirety to the "fish scales marker" in the Shaftesbury Formation in the northwestern plains of Alberta, meanwhile, reveals distinct dissimilarities. In fact, a detailed comparison of the relevant marine vertebrate faunas (see Vertebrate Faunal Distribution in the Western Interior Seaway) reveals that the Van der Voort fauna is more readily 


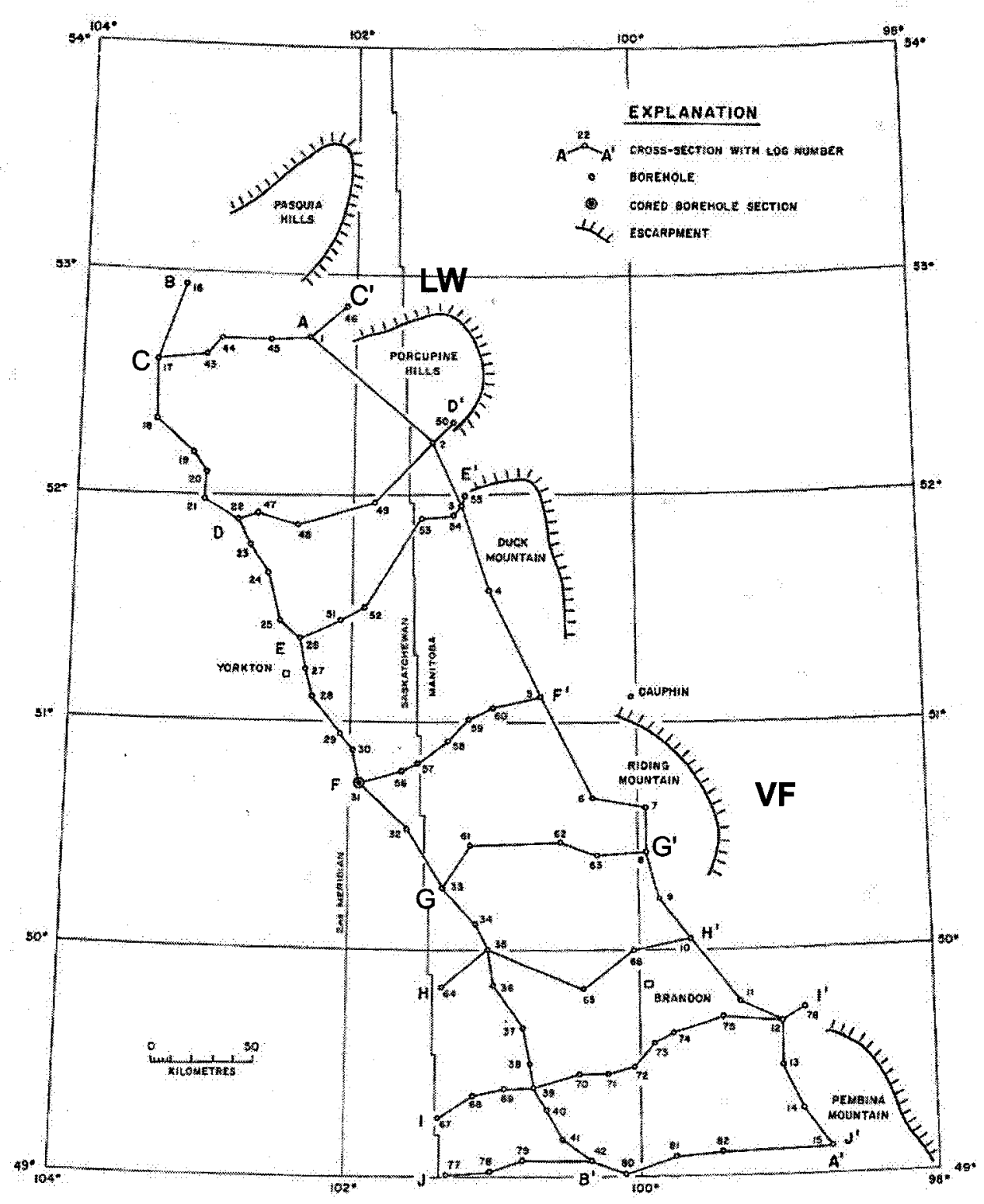

Figure 28: Index map showing McNeil and Caldwell borehole locations and lines of subsurface cross-sections. Note the proximity of section C-C' to the Little Woody River (LW) locality, and the proximity of section G-G' to the Van der Voort Farm (VF) locality. Modified from McNeil and Caldwell (1981). 
compared with that of the Pasquia Hills bonebeds described from the upper Belle Fourche Member of the Ashville Formation (e.g. Cumbaa and Tokaryk, 1999; Cumbaa et al., 2006). The Alberta "fish scales marker" fauna is actually far more readily compared to marine vertebrate faunas of the Late Albian/Early Cenomanian Mowry Shale in the northern United States (e.g. Vuke, 1984; Stewart et al., 1994; Anderson and Kowallis, 2004; Stewart and Hakel, 2006).

A final line of evidence contributing to the narrowing of the stratigraphic interval in question are samples of black shales that were collected from immediately above and below the calcarenites at the Little Woody locality, visited in 2006. Micropaleontological analysis revealed the shale to be barren of foraminifera, though they did contain abundant vertebrate (i.e. fish) bone, scale and tooth fragments, inoceramid-derived prismatic calcite crystals, and algal cysts (Schröder-Adams, pers. comm., 2007). While negative evidence of foraminifera cannot be taken as proof, these observations are consistent with the micropaleontological description of the Fish Scales Formation from the subsurface of central Saskatchewan (Bloch et al., 1993; Schröder-Adams et al., 1996). It should also be noted, however, that the Cenomanian interval in the Manitoba Escarpment is one marked by numerous shales interpreted to have been deposited under inhospitable, dysoxic to anoxic conditions (e.g. Schröder-Adams et a1., 1996; Schröder-Adams et al., 2001), and this alone may explain the lack of foraminifera.

To summarize, of all the calcarenites described by McNeil and Caldwell (1981), the one that seems most similar lithologically, sedimentologically, and paleontologically to the Van der Voort inoceramites are those described from the lower portion of the Belle Fourche Member of the Ashville Formation and likely originated at or near the level of 
the mid-Belle Fourche Member calcarenitic horizon. McNeil and Caldwell (1981) considered the calcarenitic horizon found in the middle of the Belle Fourche Member from exposures on the Wilson River to be correlative with similar outcrop exposures on the Little Woody River, and their wireline log correlations supported this correlation; these data compare favorably with the geographic situation of the Van der Voort Farm and Little Woody River localities from which calcarenites were collected for the present study. Therefore, the Van der Voort inoceramites are interpreted to have originated within the upper part of McNeil and Caldwell's "fish scale marker beds". This, coupled with molluscan and vertebrate biostratigraphic data, support the interpretation of the Van der Voort deposits as Cenomanian in age, with a stratigraphic position below the Pasquia Hills bonebeds, the " $\mathrm{X}$ " bentonite, and the Ostrea beloiti beds.

The uppermost level of the "fish scale marker beds" is approximately $5 \mathrm{~m}$ below the Ostrea beloiti beds and the " $\mathrm{X}$ " bentonite (at the type locality of the Ashville Formation along the Wilson River) within the Middle to Late Cenomanian Verneuilinoides perplexus Zone. This horizon is also no more than 10 metres above the basal 3 metres of the Belle Fourche Member in which McNeil and Caldwell (1981) recognized the Late Albian Miliammina manitobensis Zone. Taking this into consideration, along with the other evidence cited above, it seems reasonable to interpret that the upper "fish scale marker beds", and thus the Van der Voort and Little Woody inoceramites, are latest Early to (more likely) early Middle Cenomanian in age. 


\section{Taphonomic Interpretations}

Taphonomic Overprint at the Van der Voort Locality

The vertebrate remains preserved at the Van der Voort locality, like the Bainbridge River deposits, represent a significant concentration of vertebrate skeletal material. At the Bainbridge River (BR-3) locality, larger elements are more heavily abraded, while other lighter elements are better preserved. This, combined with the abundantly preserved, undeformed coprolites, has been taken to suggest a process of continual accumulation in an environment starved of terrigenous sediments, sufficiently shallow that some winnowing by waves could take place with the lighter fraction drifting away or slowly resettling, and the heavier fraction undergoing regular abrasion (Schröder-Adams et al., 2001).

A similar interpretation can readily be applied to the deposition of the Van der Voort inoceramites as well. In the Van der Voort, sharks are preserved exclusively as teeth, and bony fishes are preserved most commonly as either isolated teeth, superficial skull and jaw bones or vertebrae (with scales being somewhat less common), and all of the above being completely disarticulated and largely distributed at random over the bedding planes. The accumulation and preservation of such an assemblage may be due to a) the fact that articulated fishes were not settling to the bottom and/or b) that if they were settling to the bottom that they were subsequently disturbed (e.g. Leckie et al., 1992). Several mechanisms can contribute to such phenomena, including scattering of the bones by vertebrate or invertebrate scavengers (Elder and Smith, 1988); flotation-decay: where bloated, floating carcasses shed hard parts to the sea floor (Elder and Smith, 1988; Wilson, 1988); predation, which can contribute undigested bones from feces or gastric 
residues (Wilson, 1987; 1988); and the activity of waves and/or currents (Elder and Smith, 1988). Scavenging and flotation-decay have been recognized in the fossil record on the basis of discoveries of fragmentary and partially-articulated fishes surrounded by randomly scattered superficial bones and scales (Wilson, 1987; Elder and Smith, 1988). Predation is recognized on the basis of partially dissolved, disarticulated bones that are randomly arranged but spatially concentrated within coprolites or gastric residues (Wilson, 1987), and current-dispersal is typified by partially articulated skeletons with the superficial bones, scales and fin rays aligned in the down-current direction (Elder and Smith, 1988).

While scavenging may be impossible to rule out entirely from contributing to the taphonomic characteristics of the Van der Voort remains, it is likely to have been limited. The lack of epifaunal elements in life position, infauna and bioturbation suggests that the water column immediately above the substrate (and the substrate itself) was relatively inhospitable to animals, thus excluding benthic scavengers and inhibiting colonization. Low oxygen levels seem a likely cause of this, which is interpreted to have been common during the deposition of the shales of the Belle Fourche Member and has been proposed as a factor in the formation and preservation of other Cenomanian bioclastic concentrations (Leckie et al., 1992; Schröder-Adams et al., 1996; Schröder-Adams et al., 2001). The predation-mechanism certainly contributed to the deposition of the vertebrate fraction, as the relative abundance of microcoprolites containing inclusions of vertebrate bone attests, though these microcoprolitic inclusions account for very little of the recognized vertebrate diversity. The contribution (or lack thereof) of the other mechanisms listed above is more difficult to assess, due to the complete lack of even 
partially articulated remains. Despite the additional paucity of elements displaying current-alignment, the amount of abrasion and the relatively unimodal size distribution nonetheless argue that a significant, though not overly destructive, amount of transportation, sorting and/or reworking took place, which could very well have overprinted the signatures of other disarticulation mechanisms.

Determining whether the abundant vertebrate fossils found in the Van der Voort samples accumulated quickly (e.g as may be caused by a mass mortality event) or over a longer period of time is also difficult to assess quantitatively. It is probable, however, that these deposits accumulated over relatively long periods of time based on the preservation of microcoprolites; the observed levels of sorting by shape and size; and the amount of abrasion observed on the individual elements. Feces can vary in hardness significantly relative to an individual producer, however, even the ground mass of fecal pellets at the harder end of the spectrum would still be expected to be no more than paste-like in consistency (Hattin, 1996), and as such would be relatively soft compared to mineral grains. For relatively soft coprolites to accumulate and be preserved intact and undeformed they would need to be deposited in an environment in which they could rest on the sea floor, undisturbed, for a period of time sufficient to harden (or lithify) enough to resist disaggregation and/or compaction by winnowing, transportation, sorting, reworking and burial. An environment prone to sufficiently long periods of calm would thus be required, as well as one which could inhibit disturbance of feces by detritovores or bioturbators.

Evidence of time-averaging, defined as "the mixing of skeletal elements of noncontemporaneous populations or communities" (Walker and Bambach, 1971), also 
indicates these remains accumulated over a relatively long time period. Evidence of abrasion, fragmentation, disarticulation, and sorting by shape and size are considered to be "sensitive indicators" of time-averaging, which is also hinted at by sedimentological features which record erosion, transport, and/or low rates of sedimentation (Fursich and Aberhan, 1990). The observed levels of abrasion, fragmentation, disarticulation, sorting; the preservation of undeformed soft microcoprolites and the lack of siliciclastic grains in the Van der Voort inoceramites all fulfill these criteria. It would seem reasonable then to interpret that the vertebrate remains here accumulated over a relatively lengthy time period (possibly on the order of up to several thousand years), rather than due to a mass mortality event. While the occurrence of successive mass mortality events over a relatively long period of time are known to contribute to some substantial fossiliferous deposits (e.g. Emslie et al., 1996) and cannot be ruled out for the Van der Voort a priori, there is no specific evidence warranting such an interpretation here. Though they may have accumulated in a relatively low energy environment, the vertebrate fossils of the Van der Voort were undeniably subjected to moderate hydraulic transport as indicated by the moderate sorting, abrasion, fragmentation and disarticulation of the preserved elements. The low proportion of highly worn elements does, however, suggest that this hydraulic energy was neither highly vigorous nor persistent over long continuous periods of time. This suggests that original, pre-transport accumulation may have been in a deeper water environment, disturbed only infrequently by storm waves impinging on the sea floor. 


\section{The Comparative Taphonomic Census}

Fursich and Aberhan (1990) state that taphonomic criteria such as the degree of articulation, fragmentation and abrasion provide a qualitative measure of the exposure time of skeletal elements at the sediment-water interface and of the frequency of reworking events. While in many regards the Van der Voort inoceramites and the Bainbridge River bonebeds have been subjected to comparable taphonomic (or more specifically, biostratinomic) processes, a detailed comparison of the two deposits did reveal subtle and informative differences. The lower comparative levels of abrasion observed for vertebrate-derived elements and the preservation of many angular to subangular inoceramid-derived calcite prisms in the Van der Voort samples could indicate less time spent exposed on the sea floor, and by corollary less opportunity to be successively reworked, as well as simply lesser transport distances. The smaller overall clast sizes (both vertebrate- and inoceramid-derived) and the skewing of the distribution of the preferentially preserved clast sizes towards smaller elements would also suggest that the Van der Voort deposits were, on average, subjected to less physical reworking and ultimately deposited in a less energetic environment. The less a fossil assemblage is taphonomically altered, the less time it is inferred to have resided in the taphonomically active zone, and therefore the less it will be time-averaged (Fursich and Aberhan, 1990). Thus, it is likely that the inoceramites at the Van der Voort Farm locality underwent comparatively less time-averaging than the Bainbridge River (BR-3) bonebed.

The difference that is inferred to exist in the intensity and/or frequency of hydraulic transport and sorting of the Van der Voort and Bainbridge River (BR-3) deposits may also have had the effect of decreasing the perceived taxonomic diversity of the latter 
deposit. Blob and Fiorillo (1996) have illustrated examples of certain taxa being excluded from preservation at some localities due to the predisposition of some remains to taxonomically-controlled sizes and shapes. These taxonomic controls on the size and shape of skeletal elements can be preservationally disadvantageous within the prevailing hydraulic regime. Remains of a "basal euteleost", an early anguilliform, and an unidentified caturid are known from both the Van der Voort and Bainbridge River (BR-3) deposits, though in the Bainbridge deposit these are far less common. While it may be that this difference in abundance does reflect differences in the vertebrate paleocommunity structure at the two localities, it is worth noting that these elements are typically of a size and fragility that are preferentially preserved at the Van der Voort locality, and not at the Bainbridge.

\section{Diagenetic Interpretations}

Petrographic examination of the bone-biophospharenite revealed informative differences, predominantly in terms of the degree of mechanical compaction and the abundance of authigenic pyrite. Despite very different mineralogy, the Van der Voort inoceramites can still be meaningfully compared to the bone-biophospharenites with regard to these parameters.

Petrographers differentiate between grain fabrics indicating early cementation and mechanical compaction on the basis of the nature of the contacts between grains and the degree to which grains have been broken and plastically deformed (Meyers, 1980; Budd, 2002). A predominance of point contacts between grains and/or "floating grains" (grains surrounded entirely by interstitial cement), as well as a lack of significant grain breakage 
and plastic grain deformation are collectively taken to be indicative of early cementation, while increasing predominance of linear grain contacts and close packing, with abundant broken and/or plastically deformed grains are indicative of increasing mechanical compaction (Meyers, 1980; Budd, 2002). The vertebrate-derived clasts dominating the Bainbridge River 3 sample contact one another predominantly via point contacts, if at all, and tend to show very few signs of breakage or plastic deformation: thus they are interpreted to be indicative of early cementation. This is true also of the Van der Voort sample, though to a lesser degree, where proportionately longer contacts between inoceramid-derived calcite prisms are common while grain breakage is still rare. This is in contrast to what is observed in the other three samples where increasingly abundant linear contacts between grains, close packing, and breakage of elongate grains can be observed (in order of increasing abundance) through the Bainbridge River 1, Carrot River and Thunder Hill samples. The Thunder Hill sample in particular is very compacted, and the volume of pore-space filling cement is greatly reduced in comparison to the Bainbridge River 3 sample. The overall reduction in the volume of calcite cement in the Bainbridge River 1, Carrot River and Thunder Hill samples reduces the effective permeability of the samples with regard to the acetic acid mediated dissolution of calcite, and the increasingly grain-supported fabrics further inhibit successful disaggregation of these bonebeds using this method. The variability of the degree of compaction among the samples also contributes to interpretations of the differences in the late biostratinomic and early diagenetic histories of these samples, which will be discussed in more detail below in combination with other factors, including the abundance of authigenic pyrite. 
In order to discuss the importance of the variable amounts of authigenic pyrite in the examined samples, we must first consider some of what is known about pyrite precipitation in marine sediments. Under normal marine conditions, most authigenic pyrite precipitates within the zone of bioturbation, largely as a byproduct of the decomposition of organic matter by obligatorily anaerobic, sulfate-reducing bacteria (Berner, 1980). Commonly using organic matter as a substrate, sulphate-reducing bacteria produce hydrogen sulfide $\left(\mathrm{H}_{2} \mathrm{~S}\right)$ as a byproduct of their metabolic activity, and this in turn reacts with iron in solution to form pyrite (Littke, 1993). In normal marine sediments (i.e. in oxygenated bottom waters), the major factors controlling the rate of bacterial sulfate reduction is the amount and especially the reactivity of the organic matter being deposited in the sediment (Berner, 1984). This is in contrast to the situation in euxinic conditions (i.e. in anoxic bottom waters), where the reaction of $\mathrm{H}_{2} \mathrm{~S}$ with iron minerals can occur before and after burial, and even during sedimentation itself (Leventhal, 1983). Here, it is more the amount and reactivity of the detrital iron minerals that govern the amount of pyrite that forms, rather than the abundance of locally deposited organic matter (Berner, 1984). In further contrast to normal marine sediments, appreciable pyrite can also form under euxinic conditions where deposition rates are very low (Berner, 1984). Slow deposition, which inhibits pyrite formation in normal pelagic sediments, actually maximizes the amount of pyrite formed under euxinic conditions because slowly reacting iron compounds are given more time for reaction with $\mathrm{H}_{2} \mathrm{~S}$ (Berner, 1984).

Research has shown that the microenvironments within pellets, invertebrate and microorganismal body chambers and algal bore holes are distinct from, and only partly 
dependant on, that of the enclosing sea water, and that these internal microenvironments are distinctive in that they possess both surfaces free from abrasion and a concentration of organic tissue undergoing bacterial decay (Oppenheimer, 1960, 1961; Purdy, 1968). The same is true within vertebrate skeletal elements: Trueman et al. (2003) demonstrated that the chemical environment inside fossilized bones of shallow marine vertebrates can be distinct (low $\mathrm{pH}$, reducing) from that of the surrounding sediment, and attributed the genesis of these microenvironmental conditions to the microbial metabolism of collagen initiated in relatively fresh bones. In their example, Trueman et al. (2003) further state that the maintenance of these low-pH and low-Eh conditions inhibited extensive microbial bioerosion within the bone internal pore space and enhanced rapid pyrite mineralization. They theorized that these microenvironmental conditions were responsible for the survival of their studied vertebrate material into the fossil record due to the inhibition of microbial bioerosion, which has been theorized to accelerate bone apatite dissolution by increasing the porosity and permeability of bone (Trueman and Martill, 2002). In the inoceramite and bone-biophospharenite samples examined in the present study, pyrite precipitation was observed almost exclusively within biogenic grains, which is interpreted to result from the decay of the remnant organic matter contained within fecal pellets (preserved as microcoprolites), within the internal pore spaces and organic matrix of vertebrate bones and teeth (e.g. pulp and medullary cavities, dentine tubules), and from organic filaments which may have originally been present within the inoceramid-derived calcite prisms (e.g. Pirrie and Marshall, 1990). The paucity of pyrite in the surrounding calcite cement, meanwhile, is taken as an indication that pyrite precipitation was limited in the interstitial space. This may have been due to a lack 
of dissolved organic matter in interstitial waters. Indeed, the regions of teeth most frequently observed to contain pyrite were the smaller tubules within the dentine layer, rather then in the central pulp cavity or cavities (e.g. Fig. 21a), which would be consistent with ideal microenvironmental conditions forming first within those pore spaces most restricted from an external sea water source. Assuming then that the amount of organic tissue contained within these pore spaces (for example among comparable shark teeth or among comparable teleost teeth) is more or less constant (based on the similarity of the available pore space), it is difficult to imagine that it is the amount of organic matter which is the factor limiting the amount of pyrite which can be precipitated. This would suggest then that it is the amount of time exposed to the sulphate reduction zone which is the variable limiting the extent of pyrite precipitation in these samples, and that those bioclasts which contain the most authigenic pyrite (or that are themselves most thoroughly pyritized) are those that have resided within the sulfate reduction zone the longest.

All of the samples examined come from bioclastic horizons interbedded within the carbonaceous shales of the Belle Fourche Member of the Ashville Formation. These skeletal fragment-rich horizons are thought to have accumulated slowly over time on the sea floor, in relatively shallow, potentially nearshore waters characterized by low sedimentation rates and bottom water anoxia, which were concentrated by winnowing and reworking by storms and/or transgressive-regressive events (McNeil and Caldwell, 1981; Schröder-Adams et al., 2001; Cumbaa et al., 2006). Interestingly, in similar modern environments, the sulphate reduction zone can extend up to and even above the sediment-water interface (e.g. Leventhal, 1983), however it does not typically extend 
more than about $20 \mathrm{~cm}$ beneath the surface (summarized in Reeburgh, 1983). Indeed, partially fossilized Miocene to Recent marine vertebrate remains, concentrated there due to winnowing by bottom currents, have been collected right from the surface of the Namibian shelf and have been shown to contain crystallized globules, as well as cubic and cubic-octahedral crystals of authigenic pyrite (Moroshkin et al., 1970; Baturin, 1978; Baturin and Dubinchuk, 2003; Nemliher et al., 2004). Thus, even with low sedimentation rates, the bioclasts studied here would not have to be buried very deeply before being beyond the reach of sulphate-reducing bacteria. It can be concluded, therefore, that for a given bioclast to spend a significant time within the sulphate-reduction zone would be to spend a significant amount of time at or near the sediment-water interface. This would increase the likelihood that these elements were transported and reworked by infrequent, episodic events multiple times before final burial. The distribution of coprolites (which occur abundantly in Bainbridge River 3, commonly in the Van der Voort, very rarely in the Bainbridge River 1, and were not observed at all in the Carrot River and Thunder Hill samples) throughout the samples supports the hypothesis that perhaps the Bainbridge River 1, Carrot River, and Thunder Hill spent a greater amount of time being mobilized (or remobilized) on the sea floor, since these relatively soft particles would be removed by such processes. A lesser degree of transport is also supported by the presence of finegrained clay minerals, which are represented by macroscopic bentonite rip-up clasts in Bainbridge River 3 samples (e.g. Schröder-Adams et al., 2001). Fine-grained clay minerals were also occasionally observed packed into the "corners" of vertebrate elements seen in SEM images from the Van der Voort samples (Fig. 16b), but are absent from the other localities. 
What then might have been responsible for the relatively earlier immobilization of the largely biogenic sediments of one location over another? In the samples examined it is found that as pyrite becomes more abundant, so too do signs of mechanical compaction. Therefore, the earlier cementation occurred, the less likely (and/or frequently) a given bioclastic deposit could be remobilized. Though commenting on medium- to large-sized carbonate deposits, Morse and Mackenzie (1993) note that most changes in porosity in carbonate rocks reflect the redistribution of $\mathrm{CaCO}_{3}$ within the rocks, rather than by importation from without. As those samples which are least pyritized and least compacted are also those with the most abundantly preserved inoceramid-derived prismatic calcite, it is interpreted that these prisms provided the $\mathrm{CaCO}_{3}$ source for calcite cementation. It is beyond the scope of this study to establish whether the rates of sedimentation varied sufficiently between these localities to effectively bury some deposits beneath the sulphate-reduction zone (thus favoring earlier cementation) more rapidly than others. However, when all the evidence is considered (Fig. 29 and Fig. 30), it appears feasible that being buried along with an ample supply of inoceramid-derived calcite prisms would have improved the chances of earlier cementation, thus limiting compaction as well as the amount of time bioclasts would have spent in (and/or being reworked in) the sulphate-reduction zone. While the difference in the number of preserved inoceramid prisms may reflect the local paleoecological abundance of these bivalves at the time of deposition, it is at least as likely that bioclasts deposited in more distal environments were exposed to less frequent episodes of reworking, which would winnow out fewer of the finer grained inoceramid-derived calcite prisms. Being exposed to fewer reworking episodes early on would facilitate earlier cementation, which in turn 


\section{Degree of compaction}

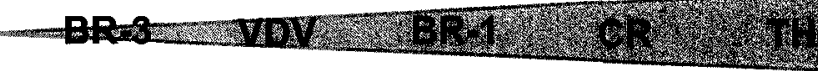

Inoceramid-derived prismatic calcite abundance

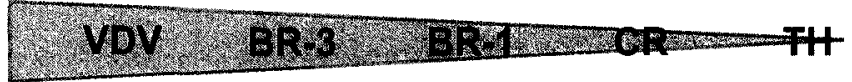

Coprolite abundance

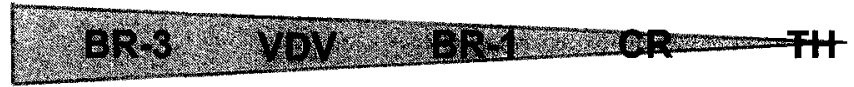

Authigenic pyrite abundance

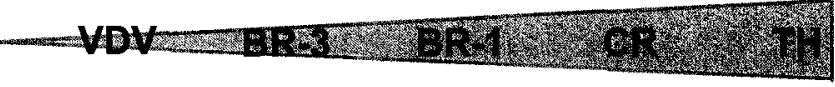

Figure 29: Summary of diagenetic trends, increasing or decreasing in degree or abundance from left to right as observed petrographically in thin sectioned samples from the Van der Voort (VDV), Bainbridge River 3 (BR-3), Bainbridge River 1 (BR-1), Carrot River (CR), and Thunder Hill (TH) localities. 


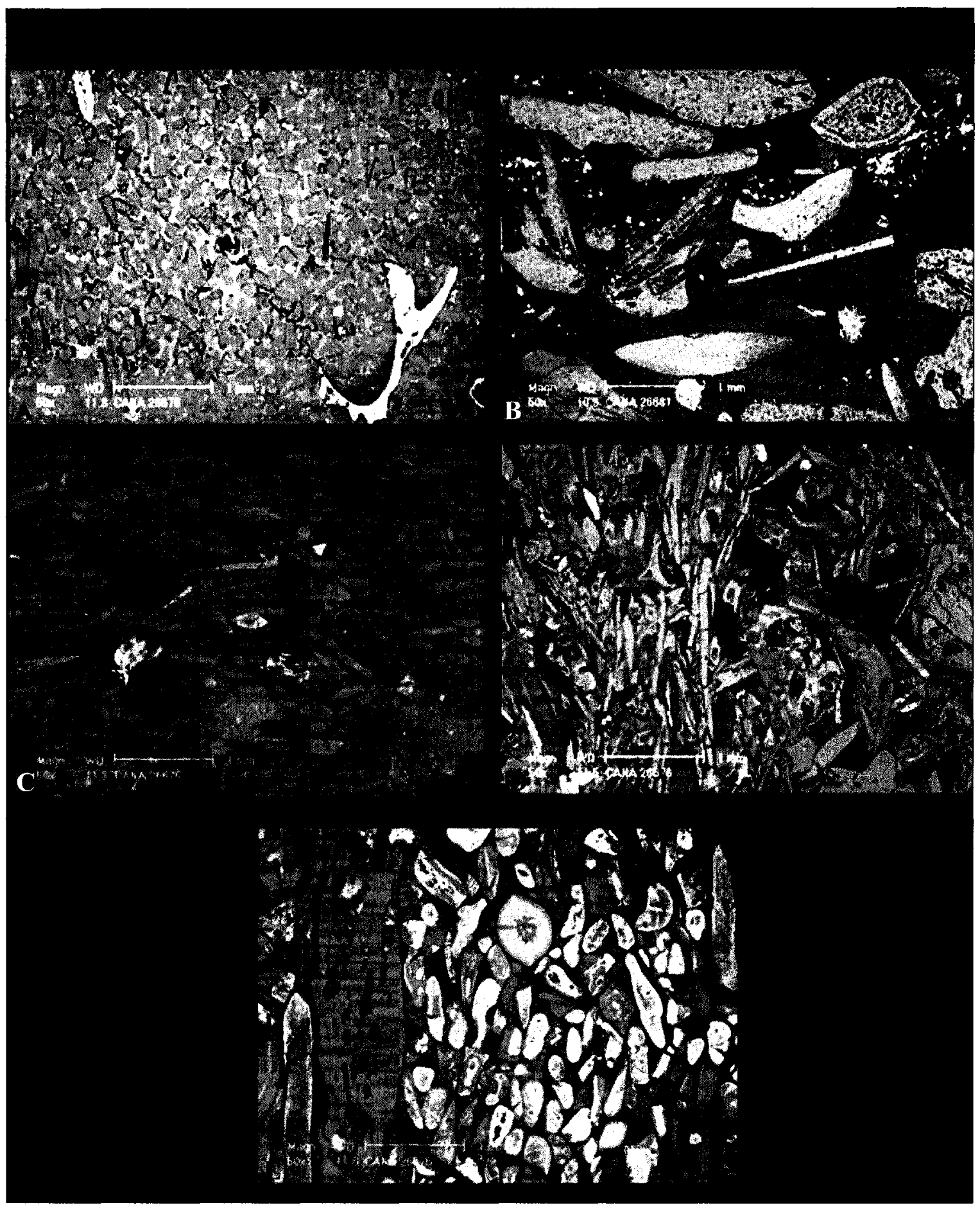

Figure 30: Comparison of representative thin sections (50X magnification) of five bioclastic accumulations from the collected from the Manitoba Escarpment. (A) Van der Voort locality: note abundant inoceramid-derived calcite prisms, sparse phosphatic elements and point contacts between grains. (B) Bainbridge River (BR-3) locality: note large "floating" phosphatic grains. (C) Bainbridge River (BR-1) locality: note increasingly linear contact between grains and increased compaction. (D) Carrot River locality: note linear grain contacts, greater compaction, and frequent splintered grains. (E) Thunder Hill locality: note rounded and abraded phosphatic elements, and high degree of pyritization. 
would protect against further reworking. The inoceramites of the Van der Voort locality and the bone-biophosparenites from elsewhere along the Manitoba Escarpment may then represent something of a continuum of bioclastic preservation: where the preservational quality of vertebrate remains is enhanced by burial along with abundant inoceramidderived prismatic calcite (relating to the abundance of inoceramids, the frequency of reworking, or both) thus affecting both the preservation of the internal microstructure of the biogenic elements, as well as the accessibility of the phosphatic elements using noninvasive, chemical preparation techniques.

\section{$\underline{\text { Paleoecology }}$}

Vertebrate Faunal Distribution in the Western Interior Seaway

A notable aspect of the paleofauna at the Van der Voort locality lies in its relatively diverse taxonomic composition. From $5.4 \mathrm{~kg}$ of inoceramite, $260.1 \mathrm{~g}$ of insoluable sediments (mostly bioclasts) was extracted. Those $260.1 \mathrm{~g}$ of sediments, combined with some pre-prepared material from the Manitoba Museum, yielded a minimum of nineteen identifiable vertebrate taxa, consisting of at least twelve chondrichthyans; at least thirteen osteichthyans; and at least one marine reptile (with another marine reptile, Brachauchenius sp., recognized from an impression of a tooth in an unprepared block collected from the Van der Voort locality in the collections of the Manitoba Museum). Considering, however, the enormous number of fragmented, unidentifiable specimens, it should also be noted that the true number of taxa is in all likelihood much greater (for example, of the 4044 bone, tooth and scale fragments retained by the $0.843 \mathrm{~mm}$ mesh size from sample VdV005, only approximately 350 could be assigned reasonable 
taxonomic identifications). The Little Woody samples, meanwhile, were only examined superficially and were found to contain specimens of Protosphyraena sp., Enchodus sp., Squalicorax falcatus, Squalicorax volgensis, Carcharias cf. C. saskatchewanensis, and Cretoxyrhina mantelli (all of which are recognized on the basis of preserved teeth); constituting an ichthyofauna consistent with that of the Van der Voort inoceramites.

Assuming that the inoceramites recovered from the Van der Voort and Little Woody River localities are early Middle Cenomanian in age, numerous taxa listed and discussed above potentially represent the earliest known occurrences. Protosphyraena sp., Squalicorax falcatus, a salmoniform and Xiphactinus audax are all examples of taxa whose occurrence here may represent their oldest North American records. Other potential examples of such taxa include Enchodus cf. E. gladiolus, Enchodus cf. E. petrosus, Enchodus cf. E. shumardi, and the Order Anguilliformes. This latter occurrence is remarkable for being roughly contemporaneous with the earliest eels known worldwide (from Lebanon) and thus indicates that by Early to Middle Cenomanian time early eels were already on both sides of the opening Atlantic Ocean.

Although no new taxa are being erected in this study, it is possible, if not likely, that some of the specimens described herein represent undescribed species. Examples include those taxa referred to here as Archaeolamna sp., "Cretoxyrhinid A", "Cretoxyrhinid B", “Cretoxyrhinid C", Carcharias sp. A, Carcharias sp. B, "Teleost A", and "Teleost B", as well as the unidentified caturid, the unidentified anguilliform, and the unidentified basal euteleost. The rationale for not describing new taxa is based primarily on the relatively small sample sizes of the elements in question, and due to their highly disarticulated nature. The high degree of disarticulation was particularly problematic with regards to the 
identification of actinopterygian fishes that lacked distinctive dental morphologies, whose identification was hampered by a paucity of published comparative data.

The vast majority of the taxa recognized in this study are relatively "typical" components of Late Cretaceous and/or more specifically Cenomanian-aged marine vertebrate paleofaunas from the Western Interior Seaway (e.g. Russell, 1988; Welton and Farish, 1993; Cappetta and Case, 1999; Cicimurri, 2001a, b; Friedman, 2004; Cumbaa et al., 2006; Shimada et al., 2006; Cook, 2007). We can see in fact that all the taxa which occur in the Van der Voort/Little Woody paleofauna also occur in the Pasquia Hills paleofauna (though there are notable differences in abundance, which will be discussed later). Indeed, when comparing the Van der Voort/Little Woody paleofauna against the Pasquia Hills and other Cenomanian-aged paleofaunas from North America, it is the absences of some taxa that are significant. These include Squalicorax curvatus, Carcharias (a.k.a. Cenocarcharias sensu Cappetta and Case, 1999) tenuiplicatus, and Cretodus semiplicatus. Ptychodontid sharks are absent from the Van der Voort /Little Woody paleofauna, whereas Ptychodus anonymus, $P$. decurrens, and/or $P$. occidentalis are not uncommon in other Cenomanian localities from the Western Interior of the United States (e.g. Welton and Farish, 1993; Shimada et al., 2006) or Canada (e.g. Cumbaa et al., 2006; Cook, 2007). In fact, the Van der Voort/Little Woody paleofauna lacks durophagus vertebrates almost entirely, containing only trace remains tentatively identified as being of pycnodontid origin. Conversely, a variety of durophagus fishes including ptychodontids, pycnodonts, plethodids, and batoids may be variably present in Cenomanian-aged deposits elsewhere (Texas, Welton and Farish, 1993; Cappetta and 
Case, 1999; Colorado, Shimada et al., 2006; Saskatchewan, Cumbaa et al. 2006; and Alberta, Cook, 2007); though rays are far rarer and less diverse in the Canadian localities. Tetrapods are also uncommon in the Van der Voort/Little Woody deposits. Dolichosaurs, mosasauroids (i.e. mosasauroidea incertae sedis), pliosaurs and polycotylids are known from the Tobe locality in Colorado (Shimada et al., 2006), while the Pasquia Hills bonebeds have been reported to contain lizards, turtles, elasmosaurs, pliosaurs, polycotylids, and even some dinosaur remains (Cumbaa and Tokaryk, 1999). A notable component of other bonebeds studied from the Manitoba Escarpment is also an abundance of fossils derived from a diverse assemblage of birds: a minimum of five species of early avians are known from the Pasquia Hills bonebeds, representing the oldest diverse avifauna known in North America (Tokaryk et al., 1997). However, no avian remains have yet been discovered amongst the samples collected from the Van der Voort or Little Woody River localities.

While comparisons against the Tobe, Pasquia Hills and Watino localities are valuable, those deposits are believed to be of a slightly younger Cenomanian age than the Van der Voort and Little Woody River deposits. As the bonebeds from these localities lie within the fish scale marker beds as recognized in the Manitoba Escarpment by McNeil and Caldwell (1981), comparison with the paleofauna of the correlative Fish Scales Formation of central Saskatchewan and the proposed Fish Scales Member of the Shaftesbury Formation in the northwestern plains of Alberta (sensu Bloch et al., 1993) is essential and informative. In the description of fauna from horizons correlative with the Fish Scales Formation found within the Shaftesbury Formation in the northwestern plains of Alberta by Leckie et al. (1992), the most abundant vertebrate recognized is the small 
teleost Osmeroides transversus. Also identified from their samples are remains assignable to the Ichthyodectidae, Enchodontiformes, and ichthyosaurs. Also known from the Fish Scales is a new species of acanthomorph teleost, Xenyllion zonensis, which is the oldest known acanthomorph (spiny-rayed) teleost from North America (Wilson and Murray, 1996).

As mentioned briefly in the "Systematic Paleontology" section, some of the unidentified teleost remains described and figured by Leckie et al. (1992) appear similar to the basal euteleost described in this study, and the evidence for the presence of enchodontoids and ichthyodectids among the inoceramites studied here is well founded. However, evidence of neither Osmeroides transversus nor Xenyllion zonensis was detected among the Van der Voort vertebrate remains. Another very notable difference between the western paleofauna of Leckie et al. (1992) and the eastern one described herein is the complete absence of chondrichthyans from the former, compared to their relative abundance and diversity in the latter. The differences then, between the paleofauna of the fish scale marker beds of the Manitoba Escarpment (as observed at the Van der Voort farm and Little Woody River localities) and the proposed Fish Scales Member of the Shaftesbury Formation of the northwestern plains of Alberta are far greater than those between the former and the later Cenomanian paleofauna of the Manitoba Escarpment known from the Pasquia Hills.

Indeed, the paleofauna of the "fish scales member" of the Shaftesbury Formation (described by Leckie et al., 1992) is, if anything, far more akin to that described from the Mowry Shale in Utah (e.g. Stewart et al., 1994; Anderson and Kowallis, 2004) and Wyoming (e.g. Vuke, 1984; Stewart and Hakel, 2006). Stewart and Hakel (2006) list 
primitive ichthyodectiforms, ichthyodectoid ichthyodectiforms, Enchodus, and Xenyllion sp. among the vertebrates collected from pelagically-deposited, fine-grained sediments of the Mowry Shale near Casper, Wyoming. Furthermore, two species of the teleost fish Holcolepis named from the Mowry Shale on the basis of scales (Cockerell, 1919) are argued by some (Cumbaa and Murray, in press) to belong in fact to the genus Osmeroides. Osmeroides sp. is also described among taxa from the Mowry Shale in Wyoming in the earlier work of Vuke (1984), along with the ichthyodectid Gillicus sp. and the ichthyosaur Platypteryginus americanus. All Cretaceous ichthyosaur material from North America has been assigned to this latter taxon, which has been listed among marine reptiles from the Mowry Shale based on fragmentary evidence by others as well (e.g. Massare and Dain, 1989). Evidence now exists that a second species lived in North America as well, at least in the northern-most reaches of the seaway in what is now the Northwest Territories (Maxwell and Caldwell, 2006). In Utah, Stewart et al. (1994) mention the presence of a possible plesiosaur, a possible crocodilian, ichthyodectiform and alepisauroid teleosts including Enchodus, and an early sphenocephalid paracanthopterygian (hypothesized by the authors to be of the genus Xenyllion). Anderson and Kowallis (2004) describe lensoid "pods" of concentrated fish teeth, bones, scales and microcoprolites from outcrops of the Mowry Shale near Vernal, Utah, and note that Enchodus is particularly abundant, while teeth of the lamniform shark Carcharias amonensis were also among those recovered. Chodrichthyans are, in fact, quite rarely mentioned among marine vertebrates from the Mowry Shale, and the most diverse assemblage, described from South Dakota, includes only four taxa: Hybodus sp., Cretodus semiplicatus, Carcharias amonensis, and a sawfish, Onchopristis dunklei 
(Cicimurri, 2004). These vertebrate assemblages demonstrate a clear resemblance to the "fish scale marker bed" of the Shaftesbury Formation.

In Wyoming and Montana, the Mowry Shale is conformably bounded by the Arrow Creek Bentonite (which has yielded an ${ }^{40} \mathrm{Ar} /{ }^{39} \mathrm{Ar}$ date of $98.52 \pm 0.41 \mathrm{Ma}$ ) below and the Clay Spur Bentonite (which has yielded an ${ }^{40} \mathrm{Ar} /{ }^{39} \mathrm{Ar}$ date of $97.17 \pm 0.69 \mathrm{Ma}$ ) above (dates from Obradovich, 1993; stratigraphy from Porter, 1998). The position of the Albian-Cenomanian boundary is controversial, and as such the Mowry Shale is placed by some workers entirely within the Late Albian (Warren and Stelk, 1969; Obradovich and Cobban, 1975; Stelk, 1975; Davis and Byers, 1993; Oboh-Ikuenobe et al., 2007), and others place it either partially or entirely within the Early Cenomanian (Hancock et al., 1993, Obradovich, 1993; Cobban and Kennedy, 1998). Obradovich's (1993) definition of the Cenomanian Age was from $98.5 \pm 0.5$ to $93.3 \pm 0.2$ Ma based on ${ }^{40} \mathrm{Ar} /{ }^{39} \mathrm{Ar}$ chronostratigraphic and molluscan biostratigraphic methods. Considering that a bentonite associated with the base of the Fish Scales Formation has yielded an ${ }^{40} \mathrm{Ar} /{ }^{39} \mathrm{Ar}$ date of 97.59 Ma (Ridgley et al., 2001), it seems likely that the Mowry Shale is temporally correlative, at least in part, with the base of the Shaftesbury Formation in the northwestern plains of Alberta, the Fish Scales Formation in central Saskatchewan, and the Belle Fourche Member of the Ashville Formation in the Manitoba Escarpment. The latter correlation is contrary to McNeil and Caldwell's (1981) interpretation that the Westgate Member of the Ashville Formation, which underlies the Belle Fourche Member, is homotaxic with the Mowry Shale.

Regardless of the exact chronostratigraphic position of the Albian-Cenomanian boundary, however, the ichthyofauna from the fish scales bed near the base of the 
Shaftesbury Formation undeniably compares more favorably with the Mowry Shale ichthyofauna than it does with that described herein from McNeil and Caldwell's (1981) "fish scale marker beds" in the Manitoba Escarpment. There are two potential explanations for these faunal differences. The first is a biogeographic explanation, proposing two separate faunas. The majority of the localities from which the Mowry Shale is described above, as well as the locality from which the fauna of the basal Shaftesbury Formation was described, are all located closer to the western margin of the WIS, contrasting the position of the Manitoba Escarpment near the eastern margin. Any number of factors potentially differentiating the paleoecological conditions of the eastern and western margins could be hypothesized, including, but not limited to, differing sedimentation rates (e.g. McNeil and Caldwell, 1981; Stott, 1984; Leckie and Rosenthal, 1986) or the differences generated by circulation patterns within the seaway (e.g. Wright, 1984). The second explanation is of biostratigraphic nature. The diversity and composition of the chondricthyan fauna, for example, known from the siliciclastically starved Pasquia Hills bonebeds is quite readily comparable to that of the clastic wedge that is the stratigraphically higher (middle Cenomanian) Dunvegan Formation in northwestern Alberta (Cook, 2007), as well as to similarily-aged chondrichthyan faunas in Colorado (Shimada et al., 2006) and Texas (Welton and Farish, 1993; Friedman, 2004). At this stratigraphic level the widespread similarities of the vertebrate faunas places the Van der Voort inoceramite fauna in the middle Cenomanian. Faunal differences between these two bioclastic accumulations might be explained by the changing paleogeography of the WIS. The bioclastic conglomerate of the basal Shaftesbury Formation, representing fishes that lived in the Mowry Sea, closed to Tethyan influence. In contrast, the fauna of 
the Van der Voort bioclastic accumulations resembles a Greenhorn Sea assemblage, influenced by sea-level rise and Tethyan-influence (Schröder-Adams et al., 1996).

\section{Paleoecological Interpretations}

There is no doubt that the taphonomic and diagenetic features of the Van der Voort inoceramites indicate that a certain degree of time-averaging took place during their deposition, and that the taxa listed above cannot simply be seen as a "snapshot" of a once living ecosystem. However, the evidence supporting the interpretation that these deposits experienced only moderate to minimal amounts of transport and reworking permits the paleofauna to be assessed as a "within-habitat time-averaged assemblage" (Kidwell and Bosence, 1991). This type of fossil assemblage consists of a mixture of many generations originating from a "single, temporally persistent community over a period of relative environmental stability" which can represent accumulation over years to thousands of years (Kidwell and Flessa, 1996). In comparing the lower overall concentration of vertebrate fossils, the smaller clast sizes, the lower degree of abrasion, and the signs of early cementation observed in the Van der Voort inoceramites with the bone-biophospharenites from the Bainbridge River (both BR-3 and BR-1), the Carrot River, and the Thunder Hill localities, it appears likely that the Van der Voort inoceramites may contain the least time-averaged Cenomanian vertebrate assemblage yet collected and described from the Manitoba Escarpment.

In agreement with Cumbaa et al. (2006), this study confirms that both bony fishes and sharks are more diverse and abundant in northern waters during the Early to Middle Cenomanian than previously recognized. During the Middle through Late Cretaceous, the North American climate was warmer than at present and was at least seasonally humid 
(e.g. Glancy et al., 1993). A "north equals cooler" generalization being usually quite safe in relation to global climatic patterns, it may be something of an oversimplification regarding the temperatures in the Western Interior Seaway during the Cenomanian. Preliminary oxygen isotope data from fossil fish teeth indicate warmer paleotemperatures in the Western Interior Seaway during the Cenomanian in Saskatchewan than in the Santonian and Campanian in Kansas and Alabama, respectively (Munro, 2000). More recently, a large oxygen isotope study of fossil fish teeth by Pucéat et al. (2003) indicated a thermal optimum in Cenomanian oceans, with lower latitudinal thermal gradients than today. Therefore, the high diversity of fishes at the Van der Voort locality is likely due, at least in part, to this warmer climate; elasmobranchs in particular would benefit from these warmer conditions (see Compagno, 1984 for modern shark distributions). Results from Cenomanian bonebeds in Canada are in contrast to previously described vertebrate faunas of the northern part of the Western Interior Seaway interpreted to have lived in mild- to cool-temperate conditions during Coniacian through Maastrichtian time. These assemblages are described as being of low diversity in all groups; dominated by plesiosaurs, hesperornithiforms, and the mosasaur genus Platecarpus, with rare turtles and sharks (Nicholls and Russell, 1990).

All of the specimens examined from the Van der Voort locality consist of completely disarticulated and fragmented teeth, bones and scales, and as such direct evidence of paleoecological dynamics is virtually non-existent. The only exception is the relatively common microcoprolites that contain vertebrate inclusions (e.g. Plate XI, Fig. 7), however, these are of relatively uncertain origin. Nevertheless, the diversity of 
vertebrates recognized at the Van der Voort locality implies that the paleofauna possessed diverse life habits, and were connected via complex trophic relationships.

The most conspicuous vertebrates, in terms of size, at the Van der Voort locality are primarily "large" macrophagous carnivores. Examples include cretoxyrhinid sharks, "crow sharks" of the genus Squalicorax, the bizarre pachycormiform Protosphyraena, the giant teleost Xiphactinus, and the plesiosaur Brachauchenius (all have estimated total body lengths of $1.5 \mathrm{~m}$ or greater). All have been putatively described as predators (or in the case of Squalicorax, as a scavenger; Druckenmiller et al., 1993) of other vertebrates. These taxa are believed to consume prey such as chondrichthyans, osteichthyans, marine turtles, mosasaurs, plesiosaurs, marine birds, and occasional "bloat-and-float" carcasses of terrestrial vertebrates washed out to sea (e.g. Bardack, 1965; Schwimmer et al., 1997a; Shimada, 1997; Cicimurri and Everhart, 2001; Everhart et al., 2004; Shimada and Everhart, 2004; Everhart and Hamm, 2005). While no direct evidence of such trophic relationships between large predators and/or scavengers and their prey were observed in this study, it is likely that predator-prey relationships similar to those inferred from other faunas from the Western Interior Seaway would exist at the Van der Voort locality.

The majority of vertebrates from the Van der Voort locality, meanwhile, are "small" macrophagous carnivores (with estimated body lengths of less than $1.5 \mathrm{~m}$ ). These include small sharks of the genus Carcharias and bony fishes such as Elopopsis, and Enchodus, which are considered to have been piscivorous (e.g. see Campagno, 1984; Shimada and Everhart, 2003). The abundance of fossil specimens collected for each taxon may not necessarily reflect each taxon's original abundance in the paleoenvironment due to numerous variables, including inter- and intraspecific tooth 
count variations (Shimada et al., 2006) and the differing preservation potential of different skeletal structures among and between taxa (Kidwell and Flessa, 1996). This being considered, it would still be difficult to conclude that Enchodus was not a common component of the paleofauna considering the abundance of Enchodus teeth among those fossils recovered from the Van der Voort locality. Enchodus is interpreted to have likely been a pelagic predator (Goody, 1969), as well as an important food base for other marine vertebrates, having been found in the preserved stomach contents of pachyrhizodontid fishes (e.g. Shimada and Everhart, 2003), anacoracid sharks (Shimada et al., 2006) and plesiosaurs (Cicimurri and Everhart, 2001). Considering the abundance of Enchodus teeth among vertebrate bioclastic concentrations in the Western Interior Seaway (e.g. Anderson and Kowallis, 2004; Friedman, 2004; Cumbaa et al., 2006; Shimada, 2006; Shimada et al., 2006), it seems clear that Enchodus was an important link in the complex food web of these Cretaceous waters.

A group of vertebrates that are conspicuously absent are those vertebrates that are inferred to have been durophagous. As previously mentioned, ptychodontids, batoids, pycnodonts and possibly plethodids are all forms with crushing, pavement-like dentitions known from the Western Interior Seaway of both Canada and the United States (e.g. Welton and Farish, 1993; Cappetta and Case, 1999; Shimada et al., 2006; Cumbaa et al. 2006; Cook, 2007). Ptychodontids are commonly viewed as benthic elasmobranchs, and are interpreted to have been predators of ostreid and inoceramid bivalves, and possibly cirripeds (Kauffman, 1972; Stewart, 1988a; Hattin, 1996). Pycnodonts, meanwhile, were deep-bodied osteichthyans that apparently fed on shelled invertebrates such as bivalves and echinoderms (Nursall, 1996). While batoids are believed to have been less diverse in 
the northern parts of the Western Interior Seaway (Cook, 2007), the dearth of ptychodontids and pycnodonts is somewhat enigmatic considering the apparent abundance of inoceramids and ostreids (i.e. Ostrea dunveganensis) at the Van der Voort locality. Pycnodonts are in fact only tentatively included in the list of taxa from the Van der Voort locality on the basis of very fragmentary material. This lack of durophagous fishes at the Van der Voort locality may simply be due to insufficient sampling, though it is also possible to speculate that it may be due to prevalent dysoxic bottom waters excluding them from preying on the benthic inoceramids and ostreids. Many inoceramids are believed to have been adapted to live in dysoxic bottom water conditions (e.g. Kauffman, 1990; MacLeod and Hoppe, 1992; Sageman and Binna, 1997; Kauffman et al., 2007). Poorly developed benthic foraminiferal assemblages in these Cenomanian mudstones and shales have been linked to anoxic and dysoxic bottom water conditions (Schröder-Adams et al., 1996; Schröder-Adams et al., 2001).

Another "group" of osteichthyan taxa preserved in relative abundance at the Van der Voort locality are particularly "small" fishes such as the unidentified basal euteleost, the unidentified anguilliform, and the unidentified caturid. Most North American Cretaceous marine teleosts consist of relatively large-sized taxa, such as the ichthyodectids, the pachyrhizodontoids, and large enchodontids (Russell, 1988). Unlike in Tethyan ichthyofaunas (e.g. in the Cenomanian of Lebanon; Forey et al., 2003), there are relatively few small-sized fossil fishes represented in North America (Stewart, 1996). This study represents one of a growing number from the Western Interior of North America (e.g. Waldman, 1969; Wiley and Stewart, 1981; Stewart, 1984; Leckie et al., 1992; Stewart et al., 1994; Fielitz, 1996; Cumbaa and Tokaryk, 1999; Fielitz, 2002; 
Friedman, 2004; Cumbaa et al., 2006; Shimada et al., 2006; Stewart and Hakel, 2006; Cumbaa and Murray, in press) which sheds more light on those fishes which likely occupied lower positions in the ancient food web than the megafauna for which the Western Interior Seaway is more popularly known (e.g. see the cretoxyrhinid, anacoracid, ichthyodectid, mosasaur and plesiosaur stars of the 2007 film "Sea Monsters: A Prehistoric Adventure"). These smaller fishes, including the unidentified basal euteleost, the unidentified anguilliform, and the unidentified caturid, though present at localities such as the Bainbridge River (BR-3) locality, are likely under-represented there due to preservational (i.e. taphonomic) biases against fossils of that size and fragility. The taphonomic and diagenetic processes leading to the preservation of the Van der Voort inoceramites, meanwhile, worked to better preserve these smaller, more delicate skeletal elements. Interestingly, one possible paleoecological link between these species may be their preservation along-side abundant inoceramid-derived calcite prisms.

Bivalves of the extinct family Inoceramidae are preserved in a wide variety of facies beginning in the Permian (Kauffman and Runnegar, 1975; Crampton 1988) and ending in the mid-Maastrichtian (Dhondt, 1983; MacLeod and Orr, 1993). Many species were capable of growing to large sizes (e.g. specimens of Platyceramus platinus would commonly grow to over a metre in length along the growth axis, and could rarely exceed two and three metres in length; summarized in Kauffman et al., 2007) and, when the characteristic outer layer of their valves disaggregated, could produce in excess of $10^{8}$ foraminiferal-sized ( $\sim 0.1 \mathrm{~mm}$ diameter) polygonal prisms of calcite (MacLeod and Orr, 1993). Additionally, inoceramids are often the dominant to exclusive macrofossils in strata that are interpreted to have been deposited in inhospitable dysoxic bottom waters 
and found in bathyal to abyssal sedimentary rocks sampled by the Deep Sea Drilling Project (MacLeod and Hoppe, 1992). Stewart (1984) described assemblages of fossil fishes from the Upper Cretaceous Chalks of Kansas (specifically the Fairport Member of the Carlile Formation and the Smoky Hill Chalk of the Niobrara Formation) where groups comprised of up to 100 fishes and/or three separate species would be preserved within the mantle cavity of a single inoceramid. Based on the distribution of these and other fossil fish species, within and without of inoceramid valves preserved in the chalks, Stewart (1984) argued that these associations were not taphonomic artifacts but rather evidence that these small fishes were commensal symbionts with the inoceramids that would take shelter between their living valves, possibly by night. While the assemblages of fishes described by Stewart (1984) are comprised largely of halecostome fishes, they also include the halecomorph Paraliodesmus (similar to the unidentified caturid) and the only formally named species of North American Cretaceous eel, Urenchelys abditus. The basal euteleost, the anguilliform, and the caturid are all fishes which would likely not have surpassed $15 \mathrm{~cm}$ in total length (based on comparisons with related taxa, listed in "Systematic Paleontology" above) and considering the abundance of large predators in the Western Interior Seaway, the benefit of such behavior is obvious. Nilsson and Östland-Nilsson (2004) reported on 31 species of modern coral reef fishes from the Australian Great Barrier Reef that could maintain their rate of oxygen consumption in relatively severely oxygen-depleted waters and speculated that this may be of benefit to these small species in permitting them to hide from predators at night, deep within the reef, in microenvironments that would become hypoxic due to coral respiration. While it is pure speculation, it is interesting to note that such symbiotic relationships have been 
proposed for small fishes and inoceramids elsewhere in the Western Interior Seaway, and that low bottom water oxygenation may not only have limited or inhibited durophagous predation of the inoceramids themselves, but it may also have created dysoxic refugia for small fishes sheltering between their valves.

As the last of the ichthyosaurs vanished (Russell 1988, 1993) and the earliest mosasauroids began to appear (Bell and Vonloh, 1998; Vonloh and Bell, 1998; Shimada et al., 2006), the Cenomanian Age was the backdrop for a significant increase in the abundance and diversity of non-hybodontid euselachians as they spread out over much of the globe (Russell, 1993; Williamson et al., 1993; Pervushov et al., 1997). This study contributes, among other things, to a trend recognized by Shimada et al. (2006) in the literature towards a growing number of recent studies pertaining to pre-Turonian Cretaceous elasmobranch assemblages (e.g. Cicimurri, 2001a, 2001b; Cumbaa et al., 2006; Shimada et al., 2006; Cook, 2007) indicating that elasmobranchs were achieving high diversity by the Middle Cenomanian in the Western Interior Seaway. Results of this study and others (e.g. Cumbaa et al. 2006) demonstrate that bony fish abundance and diversity, particularly teleosts, has also been underestimated. This study also further contributes to a growing number of studies (e.g. Cumbaa and Tokaryk, 1999; Cumbaa et al, 2006; Cook, 2007) challenging the theory that the Cretaceous marine vertebrate paleofauna of the Western Interior Seaway in Canada can be characterized by, among other factors, a rarity of sharks (as per the Northern Interior Faunal Subprovince proposed by Nicholls and Russell, 1990). 


\section{$\underline{\text { Paleoenvironmental Interpretations }}$}

The Van der Voort inoceramites are comprised primarily of sand-sized calcite prisms derived from the disaggregated outer layer of the shells of inoceramid bivalves, in addition to abundant phosphatic vertebrate fossils (bones, teeth, and scales) and ichnofossils (microcoprolites). Disarticulated valves of the oyster Ostrea dunveganensis are also common. In the Van der Voort inoceramites, the preservation of numerous, seemingly undeformed microcoprolites indicates a continuous rain of biogenic sediment to the sea floor in relatively quiet water and without the disturbance of detritovores or bioturbators. The concentration of vertebrate fossils and ichnofossils, along with the rarity of siliciclastic components, suggests a relatively long period of deposition in an environment deprived of terrigenous input. Large vertebrate clasts are relatively few, while smaller, more delicate elements (e.g. cranial and mandibular elements of small teleosts, anguilliform vertebral elements) are preserved in greater relative abundance than in the phosphatic bonebeds found elsewhere along the Manitoba Escarpment.

The concentration of bioclasts, coupled with evidence of physical abrasion, hydraulic sorting, and the minimal time spent in the sulfate reduction zone, is consistent with a dominantly parautochthonous ("an assemblage composed of autochthonous specimens that have been reworked to some degree but not transported out of the original life habitat"; Kidwell et al., 1986), or within-habitat time-averaged (Kidwell and Bosence, 1991) assemblage. Though amalgamated and perhaps reworked, the Van der Voort inoceramites are comparatively less so (and are thus less time-averaged) than other vertebrate-rich bioclastic accumulations examined from the Manitoba Escarpment. 
The biogenic constituents of the Van der Voort and Little Woody River inoceramites appear to have been derived from the slowly accumulating rain of nektonic vertebrate bones, teeth, scales and fecal pellets into a benthos dominated by a severely limited bivalve community comprised predominantly of inoceramids and the oyster Ostrea dunveganensis. The limited diversity of benthic bivalves is suggestive of stressed ecological conditions. The affinity of inoceramid bivalves for dysoxic facies (e.g. Kauffman, 1990; MacLeod and Hoppe, 1992; Sageman and Binna, 1997; Kauffman et al., 2007), together with authigenic pyrite precipitation within preserved inoceramid prisms, suggests that this stress was largely due to low oxygen conditions at or near the sediment water interface. This would be consistent with the Belle Fourche Member of the Ashville Formation in the Manitoba Escarpment at large: finely laminated shales and bentonitic clays deposited under relatively low energy conditions with negligible siliciclastic input and low to negligible oxygen concentrations in bottom waters (e.g. McNeil and Caldwell, 1981; Schröder-Adams et al., 1996; Schröder-Adams et al., 2001).

While some taxa, such as the lamniform shark Carcharias amonensis, have been interpreted as preferentially inhabiting shallow, inshore marine waters (Welton and Farish, 1993), the apparent absence of hesperornithiforms common to northern Western Interior Seaway waters (e.g. Nicholls and Russell, 1990; Tokaryk et al., 1997; Cumbaa et al., 2006), combined with the above mentioned taphonomic and diagenetic evidence, argues against the interpretation of these sediments originating in a nearshore, possibly lagoonal paleoenvironment as with the Bainbridge River (BR-3) and Carrot River bonebeds (Schröder-Adams et al., 2001; Cumbaa et al., 2006). Indeed, it seems more 
likely that these biogenic sediments originated somewhat further from shore, in a more middle shelf-like environment, beneath storm wave base.

Before final burial, however, the biogenic clasts comprising the Van der Voort inoceramites underwent a certain amount of transport. Numerous authors have described calcarenites interbedded with mudstone beds of variable thickness, comprised principally of fine silt to medium sand-sized calcitic inoceramid prisms and Ca-phosphatic fish debris (bone fragments, scales and teeth) with secondary amounts of silt to fine-sand sized quartz grains, pyrite framboids, and phosphatized coprolites from the Late Cretaceous (Middle/Upper Cenomanian to Lower Turonian) Greenhorn Limestone in the Western Interior of the U.S. (e.g. Cobban and Scott, 1972; Kauffman, 1977; Hattin, 1975, 1986; Sageman, 1996).

Sedimentological, paleoecological, and stratigraphic features of these skeletal limestones have led to the interpretation that these deposits represent tempestites that formed in response to impingement by storm wave base during relative sea-level fall in the basin (Sageman, 1996). The depositional model proposed by Sageman (1996) involves a two-step process: (1) during sea-level fall bottom muds are eroded and winnowed, and skeletal material accumulates; a process which would have been most effective on the cratonic, eastern side of the basin, away from the diluting influence of siliciclastic sources, and was hypothesized to have been mainly driven by storms. (2) With subsequent sea-level rise, storm processes would continue to rework and transport skeletal material deeper into the basin, while relatively few, large storms would influence the deeper parts of the basin. Applying sequence stratigraphic terminology, Sageman 
(1996) interpreted these skeletal limestone packages to correspond to lowstand and early transgressive systems tracts.

Biogenic clasts (both calcitic and phosphatic) are randomly oriented to slightly crossstratified within the lensoid inoceramites at both the Van der Voort and Little Woody River localities, and the abrasion and hydraulic sorting profiles indicate significant physical transport and/or reworking (though comparatively less than the other bonebiophospharenites examined from the Manitoba Escarpment. At the Little Woody locality, contacts between the inoceramite horizons and the enveloping shales were observed to be sharp, and some vertebrate-derived clasts within the Van der Voort (e.g. Fig. 16b) show signs of having possibly been ripped-up from clay-rich facies. Though the exact relationship between the inoceramites at the Van der Voort locality and the enveloping shales of the Belle Fource Member of the Ashville Formation are not known, a depositional model akin to that described by Sageman (1996) for the tempestite deposition of skeletal limestones seems the most plausible explanation for these bioclastic concentrations. This would not be altogether different from the depositional model proposed for the bone-biophospharenite deposits at the Bainbridge and Carrot River localities (Schröder-Adams et al., 2001; Cumbaa et al., 2006), where the bonebeds are attributed to amalgamation of bioclasts on the sea floor during early transgression following a drop in sea level and/or as the result of marine erosion events.

The inoceramite horizon at the Little Woody River locality, though not the primary focus of this study, provides a proxy due to preserved column of sediments, by which the depositional history of the Van der Voort inoceramites may be illustrated. The dark shales above and below the Little Woody inoceramites represent what could be 
considered the "normal" background sedimentary regime of the Belle Fourche Member of the Ashville Formation: slow deposition of fine mud and clay particles (McNeil and Caldwell, 1981) amidst oxygen-depleted bottom waters (Schröder-Adams, 1996; Schröder-Adams, 2001). The shales are barren of benthic foraminifera, but do contain abundant algal cysts, inoceramid-derived calcite prisms, and fish bone, scale, and tooth fragments disseminated throughout (Schröder-Adams, pers. comm., 2007).

These low energy, oxygen-depleted bottom waters supported only a limited epifaunal community (inoceramids and Ostrea dunveganensis), and vertebrate bones, scales and teeth, as well as microcoprolites, slowly accumulated on the sea-floor over a relatively long time period. An eventual lowering of sea-level, however, would bring these quiet bottom waters within the range of infrequent, storm-generated wave activity, disrupting water stratification. These waves would have transported the bioclasts basinward, concentrating them as the finer clay and mud particles drifted away. The resulting deposit, which may have settled into pre-existing depressions on the sea-floor (locally expressed as lenses), was a randomly oriented mix of disarticulated bioclastic debris, identical in composition to the assemblage disseminated throughout the enveloping shales, only more concentrated. The newly deposited bioclastic concentrate may have been reworked by subsequent storm waves; however, it is unlikely that these were frequent, as evidenced by the well-preserved microcoprolites. This episodic disruption of water mass stratification was also short-lived, indicated by lack of bioturbation or epifaunal colonization of the bioclastic concentrate. Finally, the shales above the inoceramite horizon represent a return to "normal" fine-grained background sedimentation in oxygen-depleted bottom waters. 
Sea level changes are known to have been frequent in the Middle to Upper Cenomanian and into the Turonian (e.g. Laurin and Sageman, 2007; Plint and Kreitner, 2007). For the early-Late Cenomanian strata of the Doe Creek unit at the base of the Kaskapau Formation in northwestern Alberta and northeastern British Columbia, Plint and Kreitner (2007) estimated vertical relative sea level excursions of approximately 10 metres for thirteen sequences, each representing cycles spanning a maximum time range of 9 to 74 thousand years. Sea level changes of up to ten metres would have had a pronounced effect on the depth of the Western Interior Seaway over great tracts of the eastern margin, where the average depositional gradient towards the basin centre would have been negligible $\left(\ll<1^{\circ}\right.$; Sageman and Arthur, 1994). Sea level changes of similar magnitude in the early Middle Cenomanian, however frequent, may be responsible for the deposition of the Van der Voort inoceramites. Sageman (1996) further illustrated that these lowstand tempestites can be correlated westward from condensed, comparatively unconformity-riddled eastern strata to coarse, basinward-prograding clastic wedges in several regions. With further research and detailed subsurface correlations, the inoceramites of the "fish scale marker beds" of the Belle Fourche Member of the Ashville Formation in the Manitoba Escarpment have the potential to become useful sequence stratigraphic tools in recognizing the timing and magnitude of sea-level changes in the fine-grained, mud-dominated and unconformity-riddled strata of the northeastern Western Interior Seaway. 


\section{CONCLUSIONS}

The Manitoba Escarpment preserves the erosional margin of the Western Interior Seaway in Canada, and outcropped along its length are numerous Cenomanian-aged horizons remarkable for their concentration of vertebrate skeletal material. The calcarenites ("inoceramites") collected from the newly described Van der Voort and Little Woody River localities are interpreted as early Middle Cenomanian in age on the basis of comparisons against published descriptions of the strata of the Manitoba Escarpment, as well as molluscan and vertebrate biostratigraphy. These bioclast-rich samples contain, in addition to abundantly preserved inoceramid bivalve-derived calcite prisms, a minimum of twelve chondrichthyan taxa, thirteen osteichthyan taxa, and two reptilian taxa, which collectively represent the earliest truly diverse fauna known from Cenomanian-aged strata in Canada. For several taxa their presence represents the oldest known occurrence in North America; the most notable being what is likely the oldest evidence of eels from this continent. The fauna represents a diverse community of vertebrates which would have interacted with one another through complex trophic relationships.

The synthesis of taphonomic data collected from the Van der Voort samples indicates that the bioclasts were concentrated by physical processes such as winnowing by storms in the siliciclastically-starved setting of the eastern margin of the Western Interior Seaway. The Van der Voort bioclasts were transported, winnowed, and reworked to a lesser degree than the bone-biophospharenites known from the Pasquia Hills, and are therefore interpreted to have been initially deposited relatively further offshore than these latter bonebeds, beneath storm wave base. The greater distance to paleoshorelines is 
supported by the lack of typical marginal marine faunal elements. Comparison against other bioclastic concentrations from along the Manitoba Escarpment reveals that variability in the amount of inoceramid-derived prismatic calcite buried along with the concentrated vertebrate bioclasts may have affected the timing of cementation, and thus effected the amount of reworking, pyritization and compaction that the deposits would ultimately undergo. This, in turn, affects the quality of preservation of the vertebrate remains.

The Van der Voort inoceramites are believed to have been deposited as the result of storms (i.e. as tempestites) impinging on the extremely shallowly sloping sea floor of the eastern margin of the Western Interior Seaway during one of the frequent Cenomanian sea-level oscillations. Similar deposits were found in the Greenhorn Limestone of the United States, where skeletal limestones were interpreted as tempestites deposited during sea-level lowstands or early transgressive phases. With further research, deposits such as the Van der Voort and Little Woody River inoceramites may become useful tools in interpreting the sea-level history of the unconformity-riddled strata of the Manitoba Escarpment, and in better understanding its relationship with the history of the basin as a whole. 


\section{REFERENCES}

Agassiz, L., 1833-1843 [1833, 1834, 1835, 1837, 1843]. Recherches sur les poissons fossiles [5 volumes]. Imprimerie de Patitpierre, Neuchâtel, 1,420 pp.

Albright, L.B., Gillette, D.D., and Titus, A. L., 2004. Plesiosaurs from the Upper Cretaceous (Cenomanian-Turonian) Tropic Shale of Utah, Part 1 - New records of the pliosaur Brachauchenius lucasi. Journal of Vertebrate Paleontology, vol 27, p. $31-40$.

Alvarado-Ortega, J., 2004. Description and relationships of a new ichthyodectiform fish from the Tlayúa Formation (Early Cretaceous: Albian), Puebla, Mexico. Journal of Vertebrate Paleontology, vol. 24, p. 802-813.

Anderson, A.D. and Kowallis, B.J., 2004. Pods of vertebrate material from Mowry Shale (Cretaceous), Utah. Geological Society of America, Rocky Mountain Section, Abstracts with Programs, vol. 36, no. 4, 92 pp.

Antunes, M. T. and Cappetta, H., 2002. Sélaciens du Crétacé (Albien-Maastrichtien) d'Angola. Palaeontographica Abteilung A, vol. 264, p. 85-146.

Arratia, G., 1997. Basal teleosts and teleostean phylogeny. Palaeo Ichthyologica, vol. 7, p. 5-168.

Arratia, G., 1999. The monophyly of Teleostei and stem-group teleosts. Consensus and disagreements, p. 265-334: In Arratia, G. and Schultze, H.-P. (ed.s), Mesozoic Fishes 2 - systematics and fossil record. Proceedings of the international meeting Buckow, Germany, 1997. Verlag Dr. Friedrich Pfeil, München, Germany.

Badgley, C.E., 1986. Counting individuals in mammalian fossil assemblages from fluvial environments. Palaios, vol.1, p. 328-338.

Bardack, D., 1965. Anatomy and Evolution of Chirocentrid Fishes. University of Kansas Paleontological Contributions, vol. 10, 88 pp.

Bardack, D., 1968. Fossil vertebrates from the marine Cretaceous of Manitoba. Canadian Journal of Earth Sciences, vol. 5, p. 145-153.

Bardack, D. and Sprinkle, G., 1969. Morphology and relationships of saurocephalid fishes. Fieldiana, Geology Memoirs, vol. 16, p. 297-340. 
Baturin, G.N., 1978. Fosfority na dne okeanov. Phosphorites from the bottom of the oceans. USSR (SUN): Izd. Nauka, Moscow, USSR (SUN).

Baturin, G.N. and Dubinchuk, V.G., 2003. The composition of phosphatized bones in recent sediments. Lithology and Mineral Resources, vol. 38, no. 3, p. 265-274.

Beavan, N.R. and Russell, A.P., 1999. An elasmobranch assemblage from the terrestrial-marine transition Lethbridge Coal Zone (Dinosaur Park Formation: Upper Campanian), Alberta, Canada. Journal of Palaeontology, vol. 73, p. 494503.

Bell Jr., G.L. and Vonloh, J.P., 1998. New records of Turonian mosasauroids from the western United States. Dakoterra, vol. 5, p. 15-28.

Belouze, A., Gayet, M., and Atallah, C., 2003a. Les premiers Anguilliformes : I.

Révision des genres cénomaniens Anguillavus HAY, 1903 et Luenchelys nov. gen. Geobios, vol. 36, p. 241-273.

Belouze, A., Gayet, M., and Atallah, C., 2003b. Les premiers Anguilliformes : II.

Paraphylie du genre Urenchelys WOODWARD, 1900 et relations phylogénétiques. Geobios, vol. 36, p. 351-378.

Berg, L.S., 1940. Classification of fishes both recent and fossil. Trudy

Zoologicheskogo Instituta, Akademia Nauk S.S.S.R., Leningrad, vol. 5, p. 346517.

Berg, L.S., 1958. System der Rezenten und Fossilen Fischartigen und Fische. Hochschulbücher für Biologie, Berlin, $310 \mathrm{pp}$.

Berner, R.A., 1980. Early diagenesis; a theoretical approach. United States (USA): Princeton Univ. Press, Princeton, NJ, United States (USA), 241 pp.

Berner, R.A., 1984. Sedimentary pyrite formation; an update. Geochimica et Cosmochimica Acta, vol. 48, no. 4, p. 605-615.

Bhattacharya, J.P., 1994. Cretaceous Dunvegan Formation of the Western Canada Sedimentary Basin: In Mossop, G.D. and Shetson, I. (comp.), Geological Atlas of the Western Canada Sedimentary Basin, Canadian Society of Petroleum Geologists and Alberta Research Council, Calgary, Alberta, 510 pp.

Blainville, H.D. de, 1835. Description de quelques espèces de reptiles de la Californie. Nouvelles Annales du Muséum d'Histoire Naturelle, Paris, vol. 4, p. 233-296. 
Bleeker, P., 1859. Enumeratio specierum hucusque in archipelago indico observatarum. Acta Batavia Koninklijke Naturkundige Vereeniging Netherlandsch Indie, vol. 6, 276 pp.

Blob, R.W. and Fiorillo, A.R., 1996. The significance of vertebrate microfossil size and shape distributions for faunal abundance reconstructions: A Late Cretaceous example. Paleobiology, vol. 22, no. 3, p. 263-270.

Bloch, J., Schröder-Adams, C., Leckie, D.A., McIntyre, D.J., Craig, J., and Staniland, M., 1993. Revised stratigraphy of the lower Colorado Group (Albian-Turonian), western Canada. Canadian Bulletin of Petroleum Geology, vol. 41, p. 325-348.

Budd, D.A., 2002. The relative roles of compaction and early cementation in the destruction of permeability in carbonate grainstones; a case study from the Paleogene of west-central Florida, U.S.A. Journal of Sedimentary Research, vol. 72 , no. 1 , p. $116-128$.

Cadrin, A.A.J., 1992. Geochemistry and paleoenvironmental reconstruction of the Greenhorn marine cyclothem in the Western Interior Basin of Canada. Thesis. Univ. Saskatchewan, 209 pp.

Cadrin, A.A.J., Kyser, T.K.,Caldwell, W.G.E., Longstaffe, F.J., 1996. Isotopic and chemical compositions of bentonites as paleoenvironmental indicators of the Cretaceous Western Interior Seaway. Palaeogeography, Palaeoclimatology, Palaeoecology, vol. 119, p. 301-320.

Caldwell, W.G.E., Diner, R., Eicher, D.L., Fowler, S.P., North, B.R., Stelck, C.R. and von Holdt Wilhelm, L., 1993. Foraminiferal biostratigraphy of Cretaceous marine cyclothems, p. 477-520: In Caldwell, W.G.E., and Kauffman, E.G. (eds.), Evolution of the Western Interior Basin, Geological Association of Canada Special Paper, no. 39.

Cappetta, H., 1987. Chondrichthyes II. Mesozoic and Cenozoic Elasmobranchii, p. 1-193: In Schultze, H.-P. (ed.), Handbook of Paleoichthyology, vol. 3B. Gustav Fischer Verlag, Stuttgart.

Cappetta, H. and Case, G.R., 1975. Sélaciens nouveaux du Crétacé du Texas. Geobios, vol. 8, p. 303-307.

Cappetta, H. and Case, G.R,, 1999. Additions aux faunes de sélaciens du Crétacé du Texas (Albien supérieur-Campanien). Palaeo Ichthyologica, vol. 9, p. 5-111. 
Carpenter, K., 1996. A review of short-necked plesiosaurs from the Cretaceous of the Western Interior, North America. Neues Jahrbuch für Geologie und Paläontologie, Abhandlungen, vol. 201, p. 259-287.

Case, G. R., 2001. A new selachian fauna from the Coleraine Formation (Upper Cretaceous/ Cenomanian) of Minnesota. Palaeontographica Abteilung A, vol. 261, p. $103-112$.

Case, G. R., Tokaryk, T. T., and Baird, D., 1990. Selachians from the Niobrara Formation of the Upper Cretaceous (Coniacian) of Carrot River, Saskatchewan, Canada. Canadian Journal of Earth Sciences, vol. 27, p. 1084-1094.

Casier, E., 1947. Constitution et évolution de la racine dentaire des Euselachii, II. Étude comparative des types. Bulletin du Musée Royal d'Histoire Naturelle de Belgique, vol. 23, p. 1-32.

Cicimurri, D.J., 2001a. Cretaceous elasmobranchs of the Greenhorn Formation (Middle Cenomanian-Middle Turonian), western South Dakota, p. 27-43: In Santucci, V. L. and McClelland, L. (eds.), Proceedings of the Sixth Fossil Resource Conference. Geologic Resources Division Technical Report, U.S. National Park Service, Washington, DC.

Cicimurri, D.J., 2001b. Fossil selachians from the Bell Fourche Shale (Cretaceous, Cenomanian), Black Hills region of South Dakota and Wyoming. Mountain Geologist, vol. 38, p. 181-192.

Cicimurri, D.J., 2004. Early Cenomanian (Late Cretaceous) elasmobranchs from the Mowry Shale, Fall River County, South Dakota. The Mosasaur, vol. 7, p. 69-73.

Cicimurri, D.J. and Everhart, M.J., 2001. An elasmosaur with stomach contents and gastroliths from the Pierre Shale (Late Cretaceous) of Kansas. Transactions of the Kansas Academy of Science, vol. 104, p. 129-143.

Cobban, W.A. and Kennedy, W.J., 1989. The ammonite Metengonoceras Hyatt, 1903, from the Mowry Shale (Cretaceous) of Montana and Wyoming. U.S. Geological Survey Bulletin 1787-L, 11 pp.

Cobban, W.A. and Scott, G.R., 1972. Stratigraphy and ammonite fauna of the Graneros Shale and Greenhorn Limestone near Pueblo, Colorado. U.S. Geological Survey Professional Paper 645, 108 pp. 
Cobban, W.A., Walaszczyk, I., Obradovich, J.D., and McKinney, K.C., 2006. A USGS zonal table for the Upper Cretaceous Middle Cenomanian-Maastrichtian of the Western Interior of the United States based on ammonites, inoceramids, and radiometric ages. United States Geological Survey, Open File Report 2006-1250, $45 \mathrm{pp}$.

Cockerell, T.D.A., 1919. Some American Cretaceous fish scales, with notes on the classification and distribution of Cretaceous fishes. U. S. Geological Survey, Professional Paper 120, p. 165-188.

Collier, A.J., 1920. Oil field at Osage, Wyoming. U.S.G.S., Press Bulletin 9065.

Collier, A.J., 1922. The Osage oil field, Western County, Wyoming. U.S.G.S., Bulletin 736-D, p. 71-110.

Cook, E., 1995. Taphonomy of two Lower Cretaceous bone accumulations from southeastern England. Palaeogeography, Palaeoclimatology, Palaeoecology, vol.116, p. 263-270.

Cook, T., 2007. Two Late Cenomanian elasmobranch assemblages from the northern regions of the Western Interior Seaway. Journal of Vertebrate Paleontology, vol. 27 (supplement to no. 3), p. 61A.

Compagno, L.J.V., 1984. FAO Species Catalogue. Volume 4. Sharks of the World. An annotated and illustrated catalogue of shark species known to date. FAO Fisheries Synopsis vol. 125, no. 4, 655 pp.

Cope, E.D., 1870. On the Saurodontidae. Proceedings of the American Philosophical Society, vol. 11, p. 529-538.

Cope, E.D., 1872. On the families of fishes of the Cretaceous formations in Kansas. Proceedings of the American Philosophical Society, vol. 12, p. 327- 357.

Cope, E.D., 1874. Review of the Vertebrata of Cretaceous formations found west of the Mississippi River. Section I: On the mutual relationships of the Cretaceous and Tertiary formations of the west. Section II: List of species of Vertebrata from the Cretaceous formations of the west. Bulletin of the United States Geological and Geographical Survey of the Territories, vol. 1, no. 2, p. 3-48.

Crampton, J.S., 1988. Comparative taxonomy of the bivalve families Isognomonidae, Inoceramidae, and Retroceramidae. Paleontology, vol. 31, p. 965-996.

Crook, A.R., 1892. Ueber einige fossile Knochenfische aus der mittleren Kreide von Kansas. Palaeontographica, vol. 39, p. 107-124. 
Cumbaa, S.L. and Bryant, H.N., 2001. Stratigraphic position of a Late

Cretaceous (Cenomanian) bonebed, east-central Saskatchewan, p. 121-124: In Summary of Investigations, 2001, vol. 1, Miscellaneous Report 2001-4.1 Saskatchewan Geological Survey, Saskatchewan Energy and Mines.

Cumbaa, S.L. and Murray, A.M., in press. New Late Cretaceous pachyrhizodontid (Crossognathiformes) and enchodontoid (Aulopiformes) fishes and associated ichthyofauna from the Northwest Territories, Canada: In Arratia, G., and Wilson, M. (eds.), Mesozoic Fishes: Systematics, homology, and character definition: Munich, Germany, Verlag Dr. Friedrich Pfeil.

Cumbaa, S.L., Schröder-Adams, C., Day, R.G, and Phillips, A.J., 2006. Cenomanian bonebed faunas from the northeastern margin, western interior seaway, Canada, $\mathrm{p}$. 139-155: In Lucas, S.G., and Sullivan, R.M. (eds.), Late Cretaceous Vertebrates from the Western Interior, New Mexico Museum of Natural History \& Science, Bulletin 35.

Cumbaa, S.L. and Tokaryk, T.T., 1999. Recent discoveries of Cretaceous marine vertebrates on the eastern margins of the Western Interior Seaway, p. 57-63: In Summary of Investigations, 1999. vol. 1, Miscellaneous Report 1999-4.1. Saskatchewan Geological Survey, Saskatchewan Energy and Mines.

Cvancara, A.M., and Hoganson, J.W., 1993. Vertebrates of the Cannonball Formation (Paleocene) in North and South Dakota. Journal of Vertebrate Paleontology, vol. 13, no. 1, p. 1-23.

Davis, J.C., 1986. Statistics and Data Analysis in Geology ( $2^{\text {nd }}$ ed.). John Wiley \& Sons, $646 \mathrm{pp}$.

Davis, J.W., 1890. On the fossil fish of the Cretaceous Formations of Scandinavia. Scientific Transactions of the Royal Dublin Society, vol. 4, p. 363434.

Davis, H.R. and Byers, C.W., 1993. The role of bottom currents and pelagic settling in the deposition of shale in an oxygen-stratified basin: case study of the Mowry Shale (Cretaceous) of Wyoming: In Caldwell, W. G. E., and Kauffman, E. G. (eds.), Evolution of the Western Interior Basin: Geological Association of Canada Special Paper 39, p. 177-188.

Decelles, P.G and Giles, K.A., 1996. Foreland basin systems. Basin Research, vol. 8, p. 105-123. 
Dhondt, A.V., 1983. Campanian and Maastrichtian inoceramids: a review. Zitteliana, vol. 10, p. 689-701.

Diedrich, C., 2001. Ein Pectoralflossenrest von Protosphyraena sp. (Pachycormidae, Actinopterygii) aus dem Ober-Cenoman von Halle/Westf. (Teutoburger Wald, NW-Deutschland). Berichte des Naturwissenschaftlichen Vereins für Bielefeld und Umgegend, vol. 41, p. 31-44.

Dixon, J., 1993. Cretaceous tectonics and Sedimentation in Northwest Canada, p. 119-129: In Caldwell, W.G.E. and Kauffman, E.G. (eds.), Evolution of the Western Interior Basin, Geological Association of Canada Special Paper, no. 39.

Donaldson, W.S., Plint, A.G, and Longstaffe, F.J., 1998. Basement tectonic control on distribution of the shallow marine Bad Heart Formation; Peace River Arch area, Northwest Alberta. Bulletin of Canadian Petroleum Geology, vol. 46, no. 4, p.576-598.

Druckenmiller, P.S., Daun, A.J., Skulan, J.L., and Pladziewicz, J.C., 1993. Stomach contents in the Upper Cretaceous shark Squalicorax falcatus. Journal of Vertebrate Paleontology, vol. 13 (supplement to no. 3), p. 33A-34A.

Dyman, T.S., Cobban, W.A., Fox., J.E., Hammond, R.H., Nichols, D.J., Perry, W.J., Jr., Porter, K.W., Rice, D.D., Setterholm, D.R., Shurr, G.W., Tysdal, R.G., Haley, J.C., and Campen, E.B., 1994. Cretaceous rocks from southwestern Montana to southwestern Minnesota, northern Rocky Mountains, and Great Plains region, p. 5-26: In Shurr, G.W., Ludvigson, G.A., and Hammond, R.H., (eds.), Perspectives on the Eastern Margin of the Cretaceous Western Interior Basin: Boulder, Colorado, Geological Society of America Special Paper, no. 287.

Elder, R.L. and Smith, G.R., 1988. Fish taphonomy and environmental inference in paleolimnology. Palaeogeography, Palaeoclimatology, Palaeoecology, vol. 62, p. 577- 592.

Emslie, S.D., Allmon, W.D., Rich, F.J., Wrenn, J.H., and de France, S.D., 1996. Integrated taphonomy of an avian death assemblage in marine sediments from the late Pliocene of Florida. Palaeogeography, Palaeoclimatology, Palaeoecology, vol. 124 , p. $107-136$.

Everhart, M.J., Everhart, P.A., Manning, E.M., and Hattin, D.E., 2003. A Middle Turonian marine fish fauna from the upper Blue Hill Shale Member, Carlile Shale, of north central Kansas. Journal of Vertebrate Paleontology, vol. 23 (supplement to no. 3), p. 49A. 
Everhart, M.J., Everhart, P.A., and Ewell, K., 2004. A marine ichthyofauna from the Upper Dakota Sandstone (Late Cretaceous). Abstracts Missouri and Kansas Academies of Science, p. 48.

Everhart, M.J., and Hamm, S.A., 2005. A new nodosaur specimen (Dinosauria: Nodosauridae) from the Smoky Hill Chalk (Upper Cretaceous) of western Kansas. Transactions of the Kansas Academy of Science, vol. 108, p. 15-21.

Fielitz, C., 1996. A Late Cretaceous (Turonian) ichthyofauna from Lac des Bois, Northwest Territories, Canada, with paleobiogeographic comparisons with Turonian ichthyofaunas of the Western Interior Seaway. Canadian Journal of Earth Sciences, vol. 33, p. 1375-1389.

Fielitz, C., 2002. A new late Cretaceous (Turonian) basal euteleostean fish from Lac des Bois of the Northwest Territories of Canada. Canadian Journal of Earth Science, vol. 39, p. 1579-1590.

Fiorillo, A.R., 1988. Taphonomy of Hazard Homestead Quarry (Ongalla Group), Hitchcock County, Nebraska. Contributions to Geology, University of Wyoming, vol. 26, no. 2, p. 57-97.

Fisher, C.G., Reeves, K.L., Ludvigson, G.A., Carpenter, S.J. and Gonzalez, L.A., 2001. Mid-Cretaceous paleoceanography and chemostratigraphy of the eastern margin, Western Interior Seaway. Abstracts with Programs - Geological Society of America, vol. 33, no. 6, pp.19.

Forey, P.L., Littlewood, D.T.J., Ritchie, P., and Meyer, A., 1996. Interrelationships of elopomorph fishes, p. 175-192: In Stiassny, M.L.J., Parenti, L.R., and Johnson, G.D. (eds.), Interrelationships of Fishes. Academic Press, New York.

Forey, P.L., Yi, L., Patterson, C., and Davies, C.E., 2003. Fossil fishes from the Cenomanian (Upper Cretaceous) of Namoura, Lebanon. Journal of Systematic Palaeontology, vol. 1, no. 4, p. 227-330.

Forey, P.L. 1975. A fossil clupeomorph fish from the Albian of the Northwest Territories of Canada, with notes on cladistic relationships of the clupeomorphs. Journal of Zoology, vol. 175, p. 151-177.

Friedman, V., 2004. Paleontology, paleoecology and depositional environment of the Lower Eagle Ford Group in north central Texas. Thesis, University of Texas at Dallas, $176 \mathrm{pp}$.

Fürbringer, M., 1888. Untersuchungen zur Morphologie und Systematik der Vogel. Von Holkema, Amsterdam, vols. 1, 2, 1751 pp. 
Fursich, F.T. and Aberhan, M., 1990. Significance of time-averaging for paleocommunity analysis. Lethaia, vol. 23, p. 143-152.

Gayet, M. 1988. Gharbouria libanica nov. gen., nov. sp., << Salmoniforme >> nouveau en provenace d'Aïn-el-Ghâboûr, nouveau gisement cénomanien du Liban. Bulletin Muséum National d'Histoire Naturelle Paris, $4^{\mathrm{e}}$ séries, vol. 10, p. 199-225.

Gill, J.R. and Cobban, W.A., 1973. Stratigraphy and geologic history of the Montana Group and equivalent rocks, Montana, Wyoming, and North and South Dakota. U.S. Geological Survey Professional Paper 776, 37 pp.

Glancy Jr., T. J., Arthur, M.A., Barron, E.J., and Kauffman, E.G., 1993. A paleoclimate model for the North American Cretaceous (Cenomanian-Turonian) epicontinental sea, p. 219-241: In Caldwell, W.G.E., and Kauffman, E.G. (eds.), Evolution of the Western Interior Basin, Geological Association of Canada Special Paper, no. 39.

Gleddie, J., 1949. Upper Cretaceous in western Peace River plains, Alberta. American Association of Petroleum Geologists, Bulletin, vol. 33, p. 511-532.

Glickman, L.S., 1958. [Rates of evolution in lamnoid sharks]. Doklady Akademia Nauk, S.S.S.R., vol. 123, p. 568-571. (In Russian)

Glickman, L.S. and Shvazhaite, R.A., 1971. [Sharks of the family Anacoracidae from Cenomanian and Turonian of Lithuania, Pre-Volga's Region and Middle Asia]. Paleontologiia i Stratigraphiia Pribatltiki Belorussii, vol. 3, p. 185-192. (In Russian)

Goody, P.C., 1969. The relationships of certain Upper Cretaceous teleosts with special reference to the myctophoids. Bulletin of the British Museum (Natural History) Geology, Supplement 7, $255 \mathrm{pp}$.

Goody, P.C., 1976. Enchodus (Teleostei: Enchodontidae) from the Upper Cretaceous Pierre Shale of Wyoming and South Dakota with an evaluation of the North American enchodontid species. Palaeontographica Abteilung A, vol. 152, p. 91112.

Grand, L. and Bemis, W.E., 1998. Society of Vertebrate Paleontology Memoir 4: A comprehensive phylogenetic study of amiid fishes (Amiidae) based on comparative skeletal anatomy; an empirical search for interconnected patterns of natural history. Journal of Vertebrate Paleontology, vol. 18, no. 1, 690 pp. 
Greenwood, P.H., Rosen, D.E., Weitzman, S.H., and Meyers, G.S., 1966. Phyletic studies of teleostean fishes, with a provisional classification of living forms. Bulletin of the American Museum of Natural History, vol. 131, p. 339-455.

Haggart, J.W., 2006. Report on Cretaceous fossils from near Riding Mountain, Manitoba (NTS 62J); Geological Survey of Canada, unpublished Paleontological Report JWH-2006-07, 3 pp.

Hammer, Ø., Harper, D.A.T., Ryan, P.D., 2001. PAST: Paleontological statistics software package for education and data analysis. Palaeontologia Electronica, vol. 4, no. 1,9 pp.

Hancock, J.M., Kennedy, W.J., and Cobban, W.A., 1993. A correlation of the Upper Albian to basal Coniacian sequence of northwestern Europe, Texas and the United States Western Interior, p. 453-476: In Caldwell, W.G.E. and Kauffman, E.G. (eds.), Evolution of the Western Interior Basin. Geological Association of Canada, Special Paper 39.

Hattin, D.E., 1962. Stratigraphy of the Carlile Shale (Upper Cretaceous) in Kansas. Bulletin of the Kansas Geological Survey, vol. 156, 155 pp.

Hattin, D.E., 1964. Cyclic sedimentation in the Colorado Group of west-central Kansas, p. 205-207: In Symposium on cyclic sedimentation. Bulletin of the Kansas Geological Survey 169, vol. 1.

Hattin, D.E., 1965. Upper Cretaceous stratigraphy, paleontology, and paleoecology of western Kansas. Geological Society of America, Field Conference Guidebook. Annual Meeting, Kansas City, Missouri, 69 pp.

Hattin, D.E., 1975. Stratigraphy and depositional environment of the Greenhorn Limestone (Upper Cretaceous) of Kansas. Bulletin of the Kansas Geological Survey 209, 128 pp.

Hattin, D.E., 1986. Carbonate substrates of the Late Cretaceous Sea, central Great Plains and southern Rocky Mountains. Palaios, vol. 1, p. 347-367.

Hattin, D.E., 1996. Fossilized regurgitate from the Smoky Hill Member of the Niobrara Chalk (Upper Cretaceous) of Kansa, USA. Cretaceous Research, vol. 17, p. 443-450.

Hay, O.P., 1903. On a collection of Cretaceous fishes from Mount Lebanon, Syria, with descriptions of four new genera and nineteen new species. Bulletin of the American Museum of National History, vol. 19, p. 395-452. 
Hay, O.P., 1929. Second Bibliography and Catalogue of the Fossil Vertebrata of North America. Publications of the Carnegie Institute of Washington, vol. 390, p. $1-2003$.

Hay, W.W., 1989. Marginal seas as source of an oxygen minimum and origin of organic-rich deposits. American Association of Petroleum Geologists, Bulletin 73, p. 362-376.

Hay, W.W., Eicher, D.L., and Diner, R., 1993. Physical oceanography and water masses in the Cretaceous Western Interior Seaway, p. 297-318: In Caldwell, W.G.E., and Kauffman, E.G. (eds.), Evolution of the Western Interior Basin, Geological Association of Canada Special Paper, no. 39.

Heckel, J.J., 1856. Beiträge zur Kenntniss der fossilen Fische Oesterreichs: II. Denkschriften der Kaiserl Akademie der Wissenschaften, Wien, XI: p. 187-274.

Hibbard, C.W. and Graffham, A., 1945. Micropycnodon, a new name for Pycnomicrodon Hibbard and Graffham not Hay. Transactions of the Kansas Academy of Science, vol. 47, p. 404.

Hoganson, J.W. and Cvancara, A.M., 1989. Vertebrate fauna of the Cannonball Sea; the last (Paleocene) transgression into central North America. Abstracts with Programs - Geological Society of America, vol. 21, no.6, pp.310.

Hoganson, J.W. and Cvancara, A.M., 1991. Biochronologic and paleobiogeographic significance of fishes from the marine Cannonball Formation (Paleocene), North and South Dakota. Journal of Vertebrate Paleontology, vol. 11 (Supplement to No. 3), pp. 35.

Hoganson, J.W. and Murphy, E.C., 2002. Marine Breien Member (Maastrichtian) of the Hell Creek Formation in North Dakota; stratigraphy, vertebrate fossil record, and age. Abstracts with Programs - Geological Society of America, vol.31, no.7, pp.71.

Jaekel, O., 1898. Die Selachier aus dem oberen Muschel kalk Lothringens. Abhandlungen Geologische Spezialk. Elasass-Lothringen, Series 3, vol. 4, p. 273-332.

Johnson, G.D. and Patterson, C., 1996. Relationships of lower euteleostean fishes, p. 251-332: In Stiassny, M.L.J., Parenti, L.R., and Johnson, G.D. (eds.), Interrelationships of fishes. Academic Press, London. 
Jowett, D.M.S., Schröder-Adams, C.J., and Leckie, D., 2007. Sequences in the Sikanni Formation in the frontier Liard Basin of northwestern Canada - evidence for high frequency late Albian relative sea-level changes. Cretaceous Research, vol. 28 , p. 665-695.

Kardong, K.V., 2002. Vertebrates: Comparative Anatomy, Function, Evolution ( $3^{\text {rd }}$ ed.). McGraw Hill, Toronto. 762 pp.

Kauffman, E.G, 1969. Cretaceous marine cycles of the Western Interior. Mountain Geologist, vol. 6, no. 4, p. 227-245.

Kauffman, E.G., 1972. Ptychodus predation upon a Cretaceous Inoceramus. Palaeontology, vol. 15, p. 439-444.

Kauffman, E.G., 1977a. Upper Cretaceous cyclothems, biotas, and environments, Rock Canyon anticline, Pueblo, Colorado. Mountain Geologist, vol. 14, no.s 3, 4, p. 129-152.

Kauffman, E.G, 1977b. Geological and biological overview: Western Interior Cretaceous Basin, p. 75-99: In Kauffman, E.G., (ed.), Cretaceous Facies, Faunas, and Paleoenvironments across the Western Interior Basin. Field Guide: North American Paleontological Convention II. Mountain Geologist, vol.14, no. 3, 4.

Kauffman, E.G., 1988. Concepts and methods of high-resolution event stratigraphy. Annual Reviews of Earth and Planetary Science, vol. 16, p. 605-654.

Kauffman, E.G., 1990. Giant fossil inoceramid bivalve pearls, p. 66-68: In Boucot, A.J. (ed.), Paleobiologic evidence for rates of behavioral evolution and coevolution. Elsevier Science Publishing, Amsterdam, Netherlands.

Kauffman, E.G., and Caldwell, W.G.E., 1993. The Western Interior Basin in space and time, p. 1-30: In Caldwell, W.G.E., and Kauffman, E.G. (eds.), Evolution of the Western Interior Basin, Geological Association of Canada Special Paper, no. 39.

Kauffman, E.G., Harries, P.J., Meyer, C., Villamil, T., Arango, C., and Jaecks, G., 2007. Paleoecology of giant inoceramidae (Platyceramus) on a Santonian (Cretaceous) seafloor in Colorado. Journal of Paleontology, vol. 81, p. 64-81.

Kauffman, E.G., Hattin, D.E. and Powell, J.D., 1977. Stratigraphic, paleontologic, and paleoenvironmental analysis of the Upper Cretaceous rocks of Cimarron County, northwestern Oklahoma. Geological Society of America, Memoir 149, 150 pp. 
Kauffman, E.G. and Runnegar, B., 1975. Atomodesma (Bivalvia), and Permian species of the United States. Journal of Paleontology, vol. 49, p. 23-41.

Kauffman, E.G., Sageman, B.B., Kirkland, J.I., Elder, W.P., Harries, P. J., and Villamil, T., 1993. Molluscan biostratigraphy of the Cretaceous Western Interior Basin, North America, p. 397-434: In Caldwell, W.G.E., and Kauffman, E.G. (eds.), Evolution of the Western Interior Basin, Geological Association of Canada Special Paper, no. 39.

Kidwell, S.M. and Bosence, D.W.J., 1991. Taphonomy and time-averaging of marine shelly faunas. p. 115-209: In Taphonomy: Releasing the Data Locked in the Fossil Record. New York: Plenum. 560 pp.

Kidwell, S.M. and Flessa, K.W., 1995. The quality of the fossil record: populations, species, and communities. Annual Review of Ecology and Systematics, vol. 26, p. 269-299.

Kidwell, S.M., Fürsich, F.T., and Aigner, T., 1986. Conceptual framework for the analysis and classification of fossil concentrations. Palaios, vol. 1, p. 228-238.

Kyser, T.K., Caldwell, W.G.E., Whittaker, S.G. and Cadrin, A.J., 1993.

Paleoenvironment and geochemistry of the northern portion of the Western Interior Seaway during Late Cretaceous time, p. 355-378: In Caldwell, W.G.E., and Kauffman, E.G. (eds.), Evolution of the Western Interior Basin, Geological Association of Canada Special Paper, no. 39.

Laurin, J., and Sageman, B.B., 2007. Cenomanian-Turonian marginal-marine record in SW Utah: Orbital scale transgressive-regressive events during oceanic anoxic event II. Journal of Sedimentary Research, vol. 77, p. 731-756.

Leckie, D.A., Bhattacharya, J.P., Bloch, J., Gilboy, C.F., and Norris, B., 1994. Cretaceous Colorado/Alberta Group of the Western Canada Sedimentary Basin: In Mossop, G.D. and Shetson, I. (comp.), Geological Atlas of the Western Canada Sedimentary Basin, Canadian Society of Petroleum Geologists and Alberta Research Council, Calgary, Alberta, 510pp.

Leckie, D.A. and Rosenthal, L., 1986. Cretaceous depositional facies in the Western Interior: the southern Alberta transect. Canadian Society of Petroleum Geologists, Summer 1986 Fieldtrip Guidebook, 73 pp.

Leckie, D.A., Schröder-Adams, C.J. and Bloch, J., 2000. The effect of paleotopography on the late Albian and Cenomanian sea-level record of the Canadian Cretaceous interior seaway. Geological Society of America Bulletin, vol. 112, no.8, p.1179-1198. 
Leckie, D.A., Singh. C., Goodarzi, F. and Wall, J.H., 1990. Organic-rich, radioactive marine shale: a case study of a shallow-water condensed section, Cretaceous Shaftesbury Formation, Alberta. Canadian Journal of Sedimentimentary Petrology, vol. 60, p. 101-117.

Leckie, D.A., Singh, C., Bloch, J.,Wilson, M., and Wall, J., 1992. An anoxic event at the Albian-Cenomanian boundary: The Fish Scale Marker Bed, northern Alberta, Canada. Palaeogeography, Palaeoclimatology, Palaeoecology, vol. 92, p. 139166.

Leckie, D.A. and Smith, D.G., 1992. Regional setting, evolution, and depositional cycles of the Western Canada Foreland Basin, p. 9-46: In Macqueen, R.W. and Leckie, D.A. (eds.), Foreland basins and fold belts, American Association of Petroleum Geologists, Memoir 55.

Leckie, R.M., Yuretich, R.F., West, O.L.O., Finkelstein, D. and Schmidt, M., 1998. Paleoceanography of the southwestern Western Interior Sea during the time of the Cenomanian-Turonian Boundary (Late Cretaceous), p. 101-126: In Dean, W.E. and Arthur, M.A. (eds.), Stratigraphy and Paleoenvironments of the Cretaceous Western Interior Seaway, USA. SEPM Concepts in Sedimentology and Paleontology, no. 6.

Leidy, J., 1856a. Notes on the fishes in the collection of the Academy of Natural Science of Philadelphia. Proceedings of the Academy of Natural Science of Philadelphia, vol. 8, p. 1-221.

Leidy, J., 1856b. Notice of some remains of fishes discovered by Dr. John E. Evans. Proceedings of the Academy of Natural Science of Philadelphia, vol. 8, p. 256257.

Leidy, J., 1857. Remarks on Saurocephalus and its allies. Transactions of the American Philosophical Society, vol. 9, p. 91-95.

Leidy, J., 1870. Remarks on ichthyorudiolites and on certain fossil Mammalia. Proceedings of the Academy of Natural Sciences of Philadelphia, vol. 21, p. 1213.

Leidy, J., 1873. Fossil Vertebrates. Vol. 1. Pt. 1. Contributions to the Extinct Vertebrate Fauna of the Western Territories. Description of Remains of Reptiles and Fishes from the Cretaceous Formations of the Interior of the United States. Report of the United States Geological Survey of the Territories, p. 265-310. 
Leventhal, J.S., 1983. An interpretation of carbon and sulfur relationships in Black Sea sediments as indicators of environments of deposition. Geochimica et Cosmochimica Acta, vol. 47, no. 1, p. 133-137.

Ligget, G.A., Shimada, K., Bennet, S.C., and Schumacher, B.A., 2005. Cenomanian (Late Cretaceous) reptiles from northwestern Russell County, Kansas. PaleoBios, vol. 25 , no. 2 , p. $9-17$.

Linnaeus, C., 1758. Systema Naturae per Regna Tria Naturae, Secundum Classes, Ordines, Genera, Species, cum Caracteribus, Differentiis, Synonymis, Locis (tenth edition). Volume 1. L. Salvii, Holmiae (=Stockholm), $824 \mathrm{pp}$.

Littke, R., 1993. Deposition, diagenesis and weathering of organic matter-rich sediments. Lecture Notes in Earth Sciences, vol. 47, 216 pp.

MacLeod, K.G. and Hoppe, K.A., 1992. Evidence that inoceramid bivalves were benthic and harbored chemosynthetic symbionts. Geology, vol. 20, p. 117-120.

MacLeod, K.G. and Orr, W.N., 1993. The taphonomy of Maastrichtian inoceramids in the Basque region of France and Spain and the pattern of their decline and disappearance. Paleobiology, vol. 19, no. 2, p. 235-250.

Mans, D., 2007. Albian-Cenomanian foraminifera in northeastern British Columbia and western Alberta: Paleoecology and integration of biostratigraphy with allostratigraphy. Thesis, Carleton University, $182 \mathrm{pp}$.

Martin, L.D., and Stewart, J.D., 1977. Teeth in Ichthyornis (Class: Aves). Science, vol. 195(4284), p. 1331-1332.

Massare, J.A. and Dain, L.E., 1989. The marine reptiles of the Mowry Shale (Albian) of northeastern Wyoming. Journal of Vertebrate Paleontology, vol. 9, no. 3, p. $32 \mathrm{~A}$.

Maxwell, E.E. and Caldwell, M.W., 2006. Evidence for a second species of the ichthyosaur Platypterygius in North America: a new record of from the Loon River Formation (Lower Cretaceous) of northwestern Canada. Canadian Journal of Earth Science, vol. 43, p. 1291-1295.

McDonough, K.J. and Cross, T., 1991. Late Cretaceous sea level from a paleoshoreline. Journal of Geophysical Research, vol.96, p. 6591-6607.

McNeil, D.H., 1984. The eastern facies of the Cretaceous System in the Canadian Western Interior. Memoir - Canadian Society of Petroleum Geologists, vol. 9, p. 145-171. 
McNeil, D.H. and Caldwell, W.G.E., 1974. The Ostrea beloiti beds - a Cenomanian time-stratigraphic unit in the Western Interior of Canada and the United States. Geological Society of America, 1975 General Meetings, Abstract with Programs, vol.6, no. 7, p. 867 .

McNeil, D.H., and Caldwell, W.G.E., 1981. Cretaceous rocks and their foraminifera in the Manitoba Escarpment, Geological Association of Canada, Special Paper no. $21,439 \mathrm{pp}$.

Meyers, W.J., 1980. Compaction in Mississippian skeletal limestones, southwestern New Mexico. Journal of Sedimentary Petrology, vol. 50, no. 2, p. 457-474.

Monger, J.W., 1993. Cretaceous tectonics of the North American Cordillera, p. 31-47. In W.G.E., and Kauffman, E.G. (eds.), Evolution of the Western Interior Basin, Caldwell, Geological Association of Canada Special Paper, no. 39.

Moroshkin, K.V., Bubnov, V.A., and Bulatov, R.P., 1970. Circulation of Waters in the Southeastern Atlantic Ocean. Okeanologiya, vol. 10, no. 1, pp. 38-47.

Morse, J.W. and Mackenzie, F.T., 1993. Geochemical constraints on $\mathrm{CaCO}_{3}$ transport in subsurface sedimentary environments; geochemical kinetics of mineral-water reactions in the field and the laboratory. Chemical Geology, vol. 105, no. 1-3, p. 181-196.

Mossop, G.D. and Shetsen, I. (compilers), 1994. Geological Atlas of the Western Canada Sedimentary Basin: Calgary, Alberta, Canada, Canadian Society of Petroleum Geologists and Alberta Research Council, 510 pp.

Muller, J., and Henle, F.G.J., 1838-1841 [1839]. Systematische Beschreibung der Plagiostomen. Berlin, unpaginated.

Müller, A., and Diedrich, C., 1991. Selachier (Pisces, Chondrichthyes) aus dem Cenomanium von Aschelon am Teutoburger Wald (Nordrhein- Westfalen, NW-Deutshland). Geologie und Palaeontologie in Westfalen, vol. 20, p. 1-104.

Munro, L.E., 2000. 18O/16O isotopes as temperature indicators in Late Cretaceous fossil shark teeth and bony fish teeth. Unpublished B.Sc. Thesis, Carleton University, 44 pp.

Nemliher, J.G., Baturin, G.N., Kallaste, T.E. and Murdmaa, I.O., 2004. Transformation of hydroxyapatite of bone phosphate from the ocean bottom during fossilization. Lithology and Mineral Resources, vol. 39, no. 5, p. 468-479. 
Nicholls, E.L., and Russell, A.P., 1990. Paleobiogeography of the Cretaceous Western Interior Seaway of North America; the vertebrate evidence. Palaeogeography, Palaeoclimatology,Palaeoecology, vol. 79, p. 149-169.

Nielsen. K.S., 2003. Lithostratigraphy, sequence stratigraphy and paleoenvironments of the upper Colorado Group in southern Alberta and southwestern Saskatchewan; definition of the Carlile and Niobrara Formations (upper Turonian to upper Santonian). Thesis, Carleton University, $517 \mathrm{pp}$.

Nielsen. K.S., Schröder-Adams, C.J., and Leckie, D.A., 2003. A new stratigraphic framework for the Upper Colorado Group (Cretaceous) in southern Alberta and southwestern Saskatchewan, Canada. Bulletin of Canadian Petroleum Geology, vol. 51, no. 3, p. 304-346.

Nilsson, G.E. and Östland-Nilsson, S., 2004. Hypoxia in paradise: widespread hypoxia tolerance in coral reef fishes. Proceedings of the Royal Society of London B (Supplment), vol. 271, p. S30-S33.

Nursall, J.R., 1996. Distribution and ecology of pycnodont fishes, p. 115-124: In Arratia, G. and Viohl, G. (eds.), Mesozoic Fishes: Systematics and Paleoecology. Dr. Friedrich Pfeil, Munich.

Oboh-Ikuenobe, F.E., Benson, D.G., Scott, R.W., Holbrook, J.M., Evetts, M.J., and Erbacher, J., 2007. Re-evaluation of the Albian-Cenomanian boundary in the U.S. Western Interior based on dinoflagellate cysts. Review of Palaeobotany and Palynology, vol. 144, p. 77-97.

Obradovich, J.D., 1993. A Cretaceous Time Scale, p. 379-396: In Caldwell, W.G.E. and Kauffman, E.G. (eds.), Evolution of the Western Interior Basin, Geological Association of Canada Special Paper, no. 39.

Obradovich, J.D. and Cobban, W.A., 1975. A time-scale for the Late Cretaceous of the Western Interior of North America, p. 31-45. In Caldwell, W.G.E. (ed.), The Cretaceous System in the Western Interior of North America. Geological Association of Canada, Special Paper, no. 13.

O'Keefe, F. R., 2001. A cladistic analysis and taxonomic revision of the Plesiosauria (Reptilia: Sauropterygia). Acta Zoologica Fennica, vol. 213, p. 1-63.

Oppenheimer, C.H., 1960. Bacterial activity in sediments of shallow marine bays. Geochimica et Cosmochimica Acta, vol. 19, p. 244-260. 
Oppenheimer, C.H., 1961. Note on the formation of spherical aragonitic bodies in the presence of bacteria from the Bahama Bank. Geochimica et Cosmochimica Acta, vol. 23 , p. 295-296.

Owen, R., 1846. Lectures on the comparative anatomy and physiology of the vertebrate animals. Pt. I: Fishes. 304 pp.

Owen, R., 1860. Palaeontology; or, a Systematic Summary of Extinct Animals and their Geological Remains. A. and C. Black, Edinburgh, Scotland, 420 pp.

Patterson, C., 1993. Osteichthyes: Teleostei, p. 621-656: In Benton, M. J. (ed.), The Fossil Record 2. Chapman \& Hall, London. 845 pp.

Pervushov, E.M., Ivanov, A.V., and Popov, E.V., 1997. Middle and Late Cretaceous biota from the southeast of the European paleobiogeographic region. Paleontological Journal, vol. 31, p. 259-265.

Pictet, F. J. and Humbert, A., 1866. Nouvelles recherches sur les poissons fossiles du Mont Liban. Georg, Genève, vii + 114 pp.

Pirrie, D. and Marshall, J.D., 1990. Diagenesis of Inoceramus and late Cretaceous paleoenvironmental geochemistry: a case study from James Ross Island, Antarctica. Palaios, vol. 5, no. 4, p. 336-345.

Plint, A.G., 2003. Clastic sediment partitioning in a Cretaceous delta system, Western Canada; responses to tectonic and sea-level controls. Geologia Croatica, vol. 56, no. 1, p. 39-68.

Plint, A.G. and Kreitner, M.A., 2007. Extensive thin sequences spanning Cretaceous foredeep suggest high-frequency eustatic control; late Cenomanian, Western Canada foreland basin. Geology, vol. 35, no. 8, p. 735-738.

Plint, A.G. and Wadsworth, J.A., 2006. Delta-plain paleodrainage patterns reflect small-scale fault movement and subtle forebulge uplift; Upper Cretaceous Dunvegan Formation, Western Canada Foreland Basin. Special Publication Society for Sedimentary Geology, vol. 85, p. 219-237.

Porter, K.W., Dyman, T.S., Cobban, W.A., and Reinson, G.E., 1998. PostMannville/Kootenai Lower Cretaceous rocks and reservoirs, north-central Montana and southern Alberta and Saskatchewan: In Christopher, J.E., Gilboy, C.F., Paterson, D.F., and Bend, S.L. (eds.), Eighth International Williston Basin Symposium, p. 123-127. 
Pucéat, E., Lécuyer, C., Sheppard, S.M.F., Dromart, G., Reboulet, S., and Grandjean, P., 2003. Thermal evolution of Cretaceous Tethyan surface marine waters inferred from oxygen isotope composition of fish tooth enamels. Paleoceanography, vol. 18, p.1029-1040.

Purdy, E.G., 1968. Carbonate diagenesis; an environmental survey. Geologica Romana; with Italian abs, vol. 7, p. 183-227.

Radu, V., 2005. Atlas for the identification of bony fish bones from archaeological sites. Contrast-Bucuresti, $77 \mathrm{pp}$.

Rafinesque, C. S., 1810. Caratteri di alcuni nuovi generi e nuove specie di animali e piante della Sicilia. Palermo, 105 pp.

Reeburgh, W.S., 1983. Rates of biogeochemical processes in anoxic sediments. Annual Review of Earth \& Planetary Sciences, vol. 11, p. 269-298.

Rees, J. and Lindgren, J., 2005. Aquatic birds from the Upper Cretaceous (Lower Campanian) of Sweden and the biology and distribution of hesperornithiforms. Palaeontology, vol. 48, pt. 6, p. 1321-1329.

Regan, C. T., 1909. The classification of teleostean fishes. Annals and Magazine of Natural History, vol. 8, p. 75-86.

Ridgley, J.L. and Gilboy, C.F., 2001. Lithofacies architecture of the Upper Cretaceous Belle Fourche Formation, Saskatchewan, Alberta, and Montana - its relationship to the sites of shallow biogenic gas production, p. 106-120: In Summary of Investigations. Saskatchewan Geological Survey, Saskatchewan Energy \& Mines, Miscellaneous Report, vol. 1.

Ridgley, J.L., McNeil, D.H., Gilboy, C.F., Condon, S.M., and Obradovich, J.D., 2001. Structural and stratigraphic controls on sites of shallow biogenic gas accumulations in the Upper Cretaceous Belle Fouche and Second White Specks Greenhorn formations of southern Alberta, Saskatchewan and northern Montana, p. 241-270. In Anderson, D.S., Robinson, J.W., Estes-Jackson, J.E., and Coalson, E.B., (eds.), Gas in the Rockies: Denver, Colorado, Rocky Mountain Association of Geologists.

Rosen, D. E., 1973. Interrelationships of higher euteleostean fishes, p. 397-513. In Greenwood, P. H., Miles, R. S., and Patterson, C. (eds.), Interrelationships of Fishes. Zoological Journal of the Linnean Society, London, vol. 53. 
Russell, D.A., 1988. A check list of North American marine Cretaceous vertebrates including fresh water fishes. Occasional Papers of the Tyrrell Museum of Palaeontology, no. 4, $57 \mathrm{pp}$.

Russell, D.A., 1993. Vertebrates in the Western Interior Sea, p. 665-680. In Caldwell, W.G.E. and Kauffman, E.G. (eds.), Evolution of the Western Interior Basin. Geological Association of Canada Special Paper, 39.

Sageman, B.B., 1996. Lowstand tempestites: depositional model for Cretaceous skeletal limestones, Western Interior Basin. Geology, vol. 24, p. 888-892.

Sageman, B.B., and Arthur, M.A., 1994. Early Turonian paleogeographic/ paleobathymetric map, Western Interior, U.S., p. 457-470: In Caputo, M. and Peterson, J. (eds.), Mesozoic systems of the Rocky Mountain region, U.S. Society of Economic Paleontologists and Mineralogists Special Publication, Rocky Mountain Section.

Sageman, B.B., and Bina, K.R., 1997. Diversity and species abundance patterns in Late Cenomanian black shale biofacies, Western Interior, U.S. Palaios, vol. 12, p. $449-466$.

Savrda, C. E., and Bottjer, D. J., 1993. Trace fossils assemblages in fine-grained strata of the Cretaceous Western Interior, p. 621-639: In Caldwell, W.G.E. and Kauffman, E.G. (eds.), Evolution of the Western Interior Basin, Geological Association of Canada Special Paper, no. 39.

Schröder-Adams, C.J., Cumbaa, S.L., Bloch, J., Leckie, D.A., Craig, J., Seif El-Dein, S.A., Simons, D.-J.H..A.E., Kenig, F., 2001. Late Cretaceous (Cenomanian to Campanian) paleoenvironmental history of the eastern Canadian margin of the Western Interior Seaway; bonebeds and anoxic events, Palaeogeography, Palaeoclimatology, Palaeoecology, vol. 170, no.3-4, p.261-289.

Schröder-Adams, C.J., Leckie, D.A., Bloch, J., Craig, J., McIntyre, D.J., and Adams, P.J., 1996. Paleoenvironmental changes in the Cretaceous (Albian to Turonian) Colorado Group of western Canada: Microfossil, sedimentological, and geochemical evidence. Cretaceous Research, vol. 17, p. 311-365.

Schröder-Adams, C.J., Leckie, D.A., Craig, J., Bloch, J., 1999. Upper Cretaceous Colorado Group in the Pasquia Hills, Northeastern Saskatchewan: A multidisciplinary study in progress, p. 52-56: In Summary of Investigations 1999, vol.1, Saskatchewan Geological Survey, Sask. Energy and Mines, Misc. Rep. 994.1 . 
Schumacher, B. A., and Everhart, M. J., 2005. A stratigraphic and taxonomic review of plesiosaurs from the old "Fort Benton Group" of central Kansas: A new assessment of old records. Paludicola, vol. 5, p. 33-54.

Schwimmer, D.R., Stewart, J.D., and Williams, G.D., 1997a. Scavenging by sharks of the genus Squalicorax in the Late Cretaceous of North America. Palaios, vol. 12, p. 71-83.

Schwimmer, D. R., Stewart, J. D., and Williams, G. D., 1997b. Xiphactinus vetus and the distribution of Xiphactinus species in the eastern United States. Journal of Vertebrate Paleontology, vol. 17, p. 610-615.

Sea Monsters: A Prehistoric Adventure. Dir. Sean Macleod Phillips. Day's End Pictures, 2007.

Seeley, H. G., 1874. Note on some of the generic modifications of the plesiosaurian pectoral arch. Quarterly Journal of the Geological Society, London, vol. 30, p. $436-449$.

Selwyn, A.R.C., 1877. Report on exploration in British Columbia, Geological Survey of Canada, Report of Progress 1875-1876, p. 28-86.

Shimada, K., 1997. Paleoecological relationships of the Late Cretaceous lamniform shark, Cretoxyrhina mantelli (Agassiz). Journal of Paleontology, vol. 71, p. 926933.

Shimada, K., 2006. Marine vertebrates from the Blue Hill Shale Member of the Carlile Shale (Upper Cretaceous, middle Turonian) in Kansas, p. 165-175: In Lucas, S.G, and Sullivan, R.M. (eds.), Late Cretaceous Vertebrates from the Western Interior, New Mexico Museum of Natural History \& Science, Bulletin 35.

Shimada, K. and Cicimurri, D.J., 2006. The oldest record of the Late Cretaceous anacoracid shark, Squalicorax pristodontus (Agassiz), from the Western Interior, with comments on Squalicorax phylogeny, p. 177-184: In Lucas, S.G, and Sullivan, R.M. (eds.), Late Cretaceous Vertebrates from the Western Interior, New Mexico Museum of Natural History \& Science, Bulletin 35.

Shimada, K. and Everhart, M.J., 2003. Ptychodus mammillaris (Elasmobranchii) and Enchodus cf. E. shumardi (Teleostei) from the Fort Hays Limestone Member of the Niobrara Chalk (Upper Cretaceous) in Ellis County, Kansas. Transactions of the Kansas Academy of Science, vol. 106, p. 171-176. 
Shimada, K., and Everhart, M. J., 2004. Shark-bitten Xiphactinus audax (Teleostei: Ichthyodectiformes) from the Niobrara Chalk (Upper Cretaceous) of Kansas. The Mosasaur, vol. 7, p. 35-39.

Shimada, K. and Fielitz, C., 2006. Annotated checklist of fossil fishes from the Smoky Hill Chalk of the Niobrara Chalk (Upper Cretaceous) in Kansas, p. 193213: In Lucas, S.G., and Sullivan, R.M. (eds.), Late Cretaceous Vertebrates from the Western Interior, New Mexico Museum of Natural History \& Science, Bulletin 35.

Shimada, K. and Martin, D.J., 1993. Upper Cretaceous selachians from the basal Greenhorn Limestone in Russell County, Kansas (abs): Missouri and Kansas Academies of Science, vol. 13, p. 78.

Shimada, K., Schumacher, B.A., Parkin, J.A., and Palermo, J.M., 2006. Fossil marine vertebrates from the Lower most Greenhorn Limestone (Upper Cretaceous: Middle Cenomanian) in southeastern Colorado. Journal of Paleontology, Memoir 63 , p. 1-45.

Singh, C, 1983. Cenomanian microfloras of the Peace River area, northwestern Alberta. Research Council of Alberta, Bulletin 44, 322 pp.

Siverson, M., 1992. Biology, dental morphology and taxonomy of lamniform sharks from the Campanian of the Kristianstad Basin, Sweden. Palaeontology, vol. 35, p. 519-554.

Siverson, M., 1999. A new large lamniform shark from the uppermost Gearle Siltstone (Cenomanian, Late Cretaceous) of Western Australia. Transactions of the Royal Society of Edinburgh: Earth Sciences, vol. 90, p. 49-65.

Siverson, M., and Lindgren, J., 2005. Late Cretaceous sharks Cretoxyrhina and Cardabiodon from Montana, USA. Acta Palaeontologica Polonica, vol. 50, p. 301-314.

Sneed, E.D., and Folk, R.L., 1958. Pebbles in the Lower Colorado River, Texas, a study in particle morphogenesis. Journal of Geology, vol.66, p. 114-150.

Stelk, C.R., 1975. The upper Albian Miliammina manitobensis zone in northeastern British Columbia, p.253-275: In Caldwell, W.G.E (ed.), The Cretaceous System in the Western Interior of North America, Geological Association of Canada Special Paper, no. 13. 
Stelck, C.R. and Koke, K.R., 1987. Foraminiferal zonation of the Viking interval in the Hasler Shale (Albian), northeastern British Columbia. Canadian Journal of Earth Sciences, vol.24, p. 2254-2278.

Stewart, A., 1898a. A contribution to the knowledge of the ichthyic fauna of the Kansas Cretaceous. Kansas University Quarterly, vol. 7, p. 22-29.

Stewart, A., 1900. Teleosts of the Upper Cretaceous. University Geological Survey of Kansas, vol. 6, p. 257-403.

Stewart, J. D., 1978. Enterospirae (fossil intestines) from the Upper Cretaceous Niobrara Formation of western Kansas. University of Kansas Paleontological Contributions, vol. 89, p. 9-16.

Stewart, J.D., 1984. Taxonomy, paleoecology, and stratigraphy of the halecostome-inoceramid associations of the North American Upper Creatceous epicontinental seaways. Ph.D. dissertation, University of Kansas, Lawrence, 201 pp.

Stewart, J.D., 1988a. Paleoecology and the first North American West Coast record of the shark genus Ptychodus. Journal of Vertebrate Paleontology, vol. 8 (supplement to no. 3), p. 27A.

Stewart, J.D., 1988b. The stratigraphic distribution of Late Cretaceous Protosphyraena in Kansas and Alabama, p. 80-94: In, Geology, Paleontology, and Biostratigraphy of Western Kansas: Articles in Honor of Myrl V. Walker, Nelson, M.E. (ed.). Fort Hays State University Studies, Third Series, No. 10.

Stewart, J.D., 1996. Cretaceous acanthomorphs of North America, p. 383-394: In Arratia, G. and Viohl, G., (eds.), Mesozoic fishes - systematics and paleoecology. Proceedings of the international meeting, Eichstätt, Germany, 1993. Verlag Dr. Friedrich Pfeil, München, Germany.

Stewart, J. D., Bilbey, S. A., Chure, D. J., and Madsen, S. K., 1994. Vertebrate fauna of the Mowry Shale (Cenomanian) in northeastern Utah. Journal of Vertebrate Paleontology, vol. 14, p. 47A.

Stewart and Hakel, 2006. Ichthyofauna of the Mowry Shale (Early Cenomanian) of Wyoming, p. 161-163: In Lucas, S.G. and Sullivan, R.M. (eds.), Late Cretaceous Vertebrates from the Western Interior, New Mexico Museum of Natural History \& Science, Bulletin 35 . 
Stewart, J. D., and Martin, J. E., 1993. Late Cretaceous selachians and associated marine vertebrates from the Dakota Rose Quarry, Grant County, South Dakota. Proceedings of the South Dakota Academy of Science, vol. 72, p. 241-248.

Stott, D.F., 1984. Cretaceous sequences of the foothills of the Canadian Rocky Mountains, p. 85-107: In Stott, D.F. and Glass, D.J. (eds.), The Mesozoic of Middle North America, Canadian Society of Petroleum Geologists, Memoir 9.

Tarlo, L. B., 1960. A review of the Upper Jurassic pliosaurs. Bulletin of the British Museum of Natural History, vol. 4, p. 147-189.

Taverne, L., 1976. A propos d'Elopopsis microdon Heckel, J. J., 1856, du Crétacé moyen d'Afrique et d'Europe et des affinités systématiques de la famille fossile des Pachyrhizodontidae au sein des Téléostéens primitifs. Revue de Zoologie Africaine, vol. 90 , no. 2, p. 487-496.

Taverne, L., 1989. Crossognathus Pictet, 1858 du Crétacé Inférieur de L'Europe et systématique, paléozoogéographie et biologie des Crossognathiformes nov. ord. (Téléostéens) du Crétacé et du Tertiaire. Palaeontographica Abt. A, vol. 207, p. 79-105.

Taverne, L., 2004. Libanechelys bultyncki gen. et sp. nov., une nouvelle anguille primitive (Teleostei, Anguilliformes) de Cénomanien marine du Liban. Bulletin de l'Institut royal des Sciences naturelles de Belgique, Sciences de la Terre. Vol. 74, p. 73-87.

Thurmond J., 1971. Cartilaginous fishes of the Trinity Group and related rocks (Lower Cretaceous) of North Central Texas. Southeastern Geology, vol. 13, p. 207-227.

Tokaryk, T.T., Cumbaa, S.L., and Storer, J.E., 1997, Early Late Cretaceous birds from Saskatchewan, Canada: the oldest diverse avifauna known from North America. Journal of Vertebrate Paleontology, vol. 17, p. 172-176.

Trueman, C.N., Benton, M.J., and Palmer, M.R., 2003. Geochemical taphonomy of shallow marine vertebrate assemblages. Palaeogeography, Palaeoclimatology, Palaeoecology, vol. 197, p. 151-169.

Trueman, C.N. and Martill, D.M., 2002. The long term preservation of bone: The role of bioerosion. Archaeometry, vol. 44, p. 371-382. 
Tyagi, A., Varban, B.L., Plint, A.G., and McNeil, D., 2005. High-resolution stratigraphy of marine mustones reveals forebulge response to loading, and shifting thrust loads, Western Canada foreland basin. Geological Society of America, Abstracts with Programs, vol. 37, no. 7, p. 338.

Tyagi, A., Plint, A.G, and McNeil, D.H., 2007. Correlation of physical surfaces bentonites, and biozones in the Cretaceous Colorado Group from the Alberta Foothills to southwest Saskatchewan, and a revision of the Belle Fourche Second White Specks formational boundary. Canadian Journal of Earth Sciences, vol. 44, p. 871-888.

Vullo, R., Néraudeau, D., and Videt, B., 2003. Un faciès de type falun dans le Cénomanien basal de Charente-Maritime (France). Annales de Paléontologie, vol. 89, p. 171-189.

Waage, K.M., 1978. Deciphering the basic sedimentary structure of the Cretaceous System in the Western Interior, p.55-81; In Caldwell, W.G..E. (ed.), The Cretaceous System in the Western Interior of North America. Geological Association of Canada, Special Paper, no. 13.

Waldman, M., 1969. Ichthyodectes and Holcolepis from the Cretaceous of Lac des Bois, Northwest Territories, Canada. Canadian Journal of Earth Sciences, vol. 6, p. $1316-1319$.

Walker, K.R., and Bambach, R.K., 1971. The significance of fossil assemblages from fine-grained sediments: time-averaged communities. Geological Society of America, Abstracts with Programs, vol. 3, p. 783-784.

Wall, J.H., 1967. Cretaceous foraminifera of the Rocky Mountain Foothills, Alberta. Research Council of Alberta, Bulletin 20, 185 pp.

Warren, P.S., 1930. Palaeontology. New species of fossils from Smoky River and Dunvegan formations, Alberta. Appendix in Rutherford, R.L., Geology and Water Resources in parts of the Peace and Grand Prairie districts, Alberta; Research Council of Alberta, Report No. 21, p. 57-68.

Warren, P.S. and Stelck, C.R., 1969. Early Neogastroplites Fort St. John Group, western Canada. Bulletin of Canadian Petroleum Geology, vol. 17, p. 529-547.

Welles, S. P., 1943. Elasmosaurid plesiosaurs with a description of the new material from California and Colorado. University of California Memoirs, vol. 13, p. 125254. 
Welton, B. J. and Farish, R. F., 1993. The Collector's Guide to Fossil Sharks and Rays from the Cretaceous of Texas. Before Time, Lewisville, Texas, 204 pp.

White, T. and Arthur, M.A., 2006. Organic carbon production and preservation in response to sea-level changes in the Turonian Carlile Formation, U.S. Western Interior Basin. Palaeogeography, Palaeoclimatology, Palaeoecology, vol. 235, no.1-3, p. 223-244.

Whitley, G. P., 1939. Taxonomic notes on sharks and rays. Australian Journal of Zoology, vol. 9, no. 3, p. 227-262.

Wiley, E.O., and Stewart, J.D., 1981. Urenchelys abditus, new species, the first undoubted eel (Teleostei :Anguilliformes) from the Cretaceous of North America. Journal of Vertebrate Paleontology, vol. 11, p. 43-47.

Williams, G.D. and Stelck, C.R., 1975. Speculations on the Cretaceous palaeogeography of North America, p. 1-20: In Caldwell, W.GE. (ed.), The Cretaceous System of the Western Interior of North America, Geological Association of Canada, Special Publication, no. 13.

Williamson, T. E., Kirkland, J. I. and Lucas, S. G., 1991. The Cretaceous elasmobranch Ptychodus decurrens Agassiz from North America. Geobios, vol. 24, p. 595-599.

Williamson, T.E., Kirkland, J.I., and Lucas, S.G., 1993. Selachians from the Greenhorn Cyclothem ("Middle" Cretaceous: Cenomanian-Turonian), Black Mesa, Arizona, and the paleogeographic distribution of Late Cretaceous selachians. Journal of Paleontology, vol. 67, p. 447-474.

Williston, S.W., 1900. Some fish teeth from the Kansas Cretaceous. Kansas University Quarterly, vol. 9, p. 27-42.

Williston, S.W., 1903. North American plesiosaurs. Field Columbian Museum, Publication 73, geological series, vol. 2, p. 1-79.

Wilson, M.V.H., 1978. Upper Cretaceous marine Teleostei form the basal Kanguk Formation, Banks Island, Northwest Territories. Canadian Journal of Earth Sciences, vol. 15, p. 1799-1807.

Wilson, M.V.H., 1987. Predation as a source of fish fossils in Eocene lake sediments. Palaios, vol. 2, p. 497-504.

Wilson, M.V.H., 1988. Taphonomic processes: information loss and information gain: Paleocene 9. Geoscience Cananda, vol. 15, p. 131-148. 
Wilson, M.V.H., and Chalifa, Y. 1989. Fossil marine actinopterygian fishes from the Kaskapau Formation (Upper Cretaceous: Turonian) near Watino, Alberta. Canadian Journal of Earth Sciences, vol. 26, p. 2604-2620.

Wilson, M.V.H., and Murray, A.M., 1996. Early Cenomanian acanthomorph teleost in the Cretaceous Fish Scale Zone, Albian/Cenomanian Boundary, Alberta, Canada, p. 369-382: In Arratia, G and Viohl, G. (ed.), Mesozoic Fishes Systematics and Paleoecology. Proceedings of the International Meeting Eichstätt, 1996. Munich, Germany (Verlag Dr. Friedrich Pfeil).

Woodward, A.S., 1895. Catalogue of the Fossil Fishes in the British Museum, Pt. 3. British Museum of Natural History, London, 544 pp.

Woodward, A.S., 1900. Evidence of an extinct eel (Urenchelys anglicus $\mathbf{n}$. sp.) from the English Chalk. Annals and Magazine of Natural History, vol. 7, no. 5, p. 321323.

Woodward, A.S., 1901. Catalogue of the fossil fishes in the British Museum (Natural History), Pt. 4. Trustees of the British Museum (Natural History), London, vol. $17,636 \mathrm{pp}$.

Woodward, A.S., 1902-1912 [1908]. The Fossil Fishes of the English Chalk. Palaeontographical Society, London, 264 pp.

Wright, E.K., 1984. Stratification and paleocirculation of the Late Cretaceous Western Interior Seaway of North America. Geological Society of America Bulletin, vol. 99, p. 480-490.

Vonloh, J.P. and Bell Jr., G.L., 1998. Fossil reptiles from the Late Cretaceous Greenhorn Formation (Late Cenomanian-Middle Turonian) of the Black Hills region, South Dakota. Dakoterra, vol. 5, p. 29-38.

Vuke, S.M., 1984. Depositional environments of the Early Cretaceous western interior seaway in southwestern Montana and the northern United States. Canadian Society of Petroleum Geologists Memoir 9, p. 127-144. 


\section{PLATES}




\section{PLATE I}

Figure 1: Hybodus butleri tooth (MM V-2923), labial (left) and lingual (right) views.

Figure 2: Ptychodus cf. $P$. decurrens tooth (P 3015.1), occlusal (left), labial (centre, top), lingual (centre, bottom) and basal (right) views. Specimen collected as float from along the Bainbridge River between localities BR-3 and BR-2 locality.

Scale bars equal $2 \mathrm{~mm}$ 


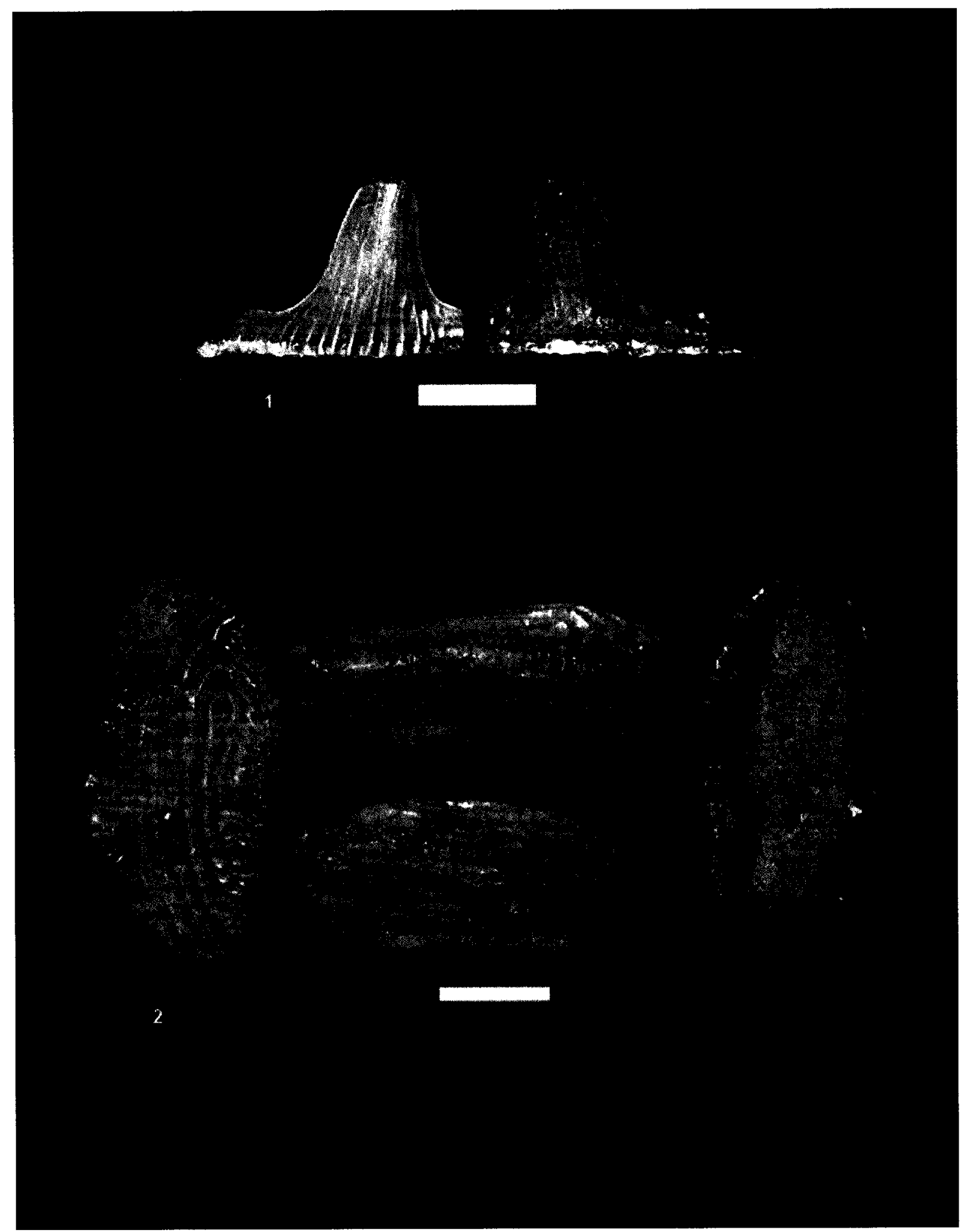




\section{PLATE II}

Figure 1: Squalicorax volgensis right(?) anterior tooth (MM V-2924), lingual (left) and labial (right) views

Figure 2: Squalicorax volgensis left parasymphyseal(?) tooth (MM V-2925), lingual (left) and labial (right) views

Figure 3: Squalicorax volgensis right anterolateral tooth (MM V-2926), lingual (left) and labial (right) views

Figure 4a: Squalicorax volgensis left anterolateral tooth (MM V-2927), lingual (top) and labial (bottom) views.

Figure 4b (inset): Squalicorax volgensis left anterolateral tooth (MM V-2927) magnification of irregular serrations

Figure 5: Squalicorax volgensis right lateral tooth (MM V-2928), lingual (left) and labial (right) views

Figure 6: Squalicorax volgensis left lateral tooth (MM V-2929), lingual (left) and labial (right) views

Figure 7: Squalicorax falcatus left anterolateral tooth (MM V-2930), lingual (left) and labial (right) views

Figure 8a: Squalicorax falcatus broken anterolateral tooth (MM V-2931), lingual (left) and labial (right) views

Figure 8b (inset): Squalicorax falcatus broken anterolateral tooth (MM V-2931) magnification of serrations

Scale bars equal $2 \mathrm{~mm}$ 


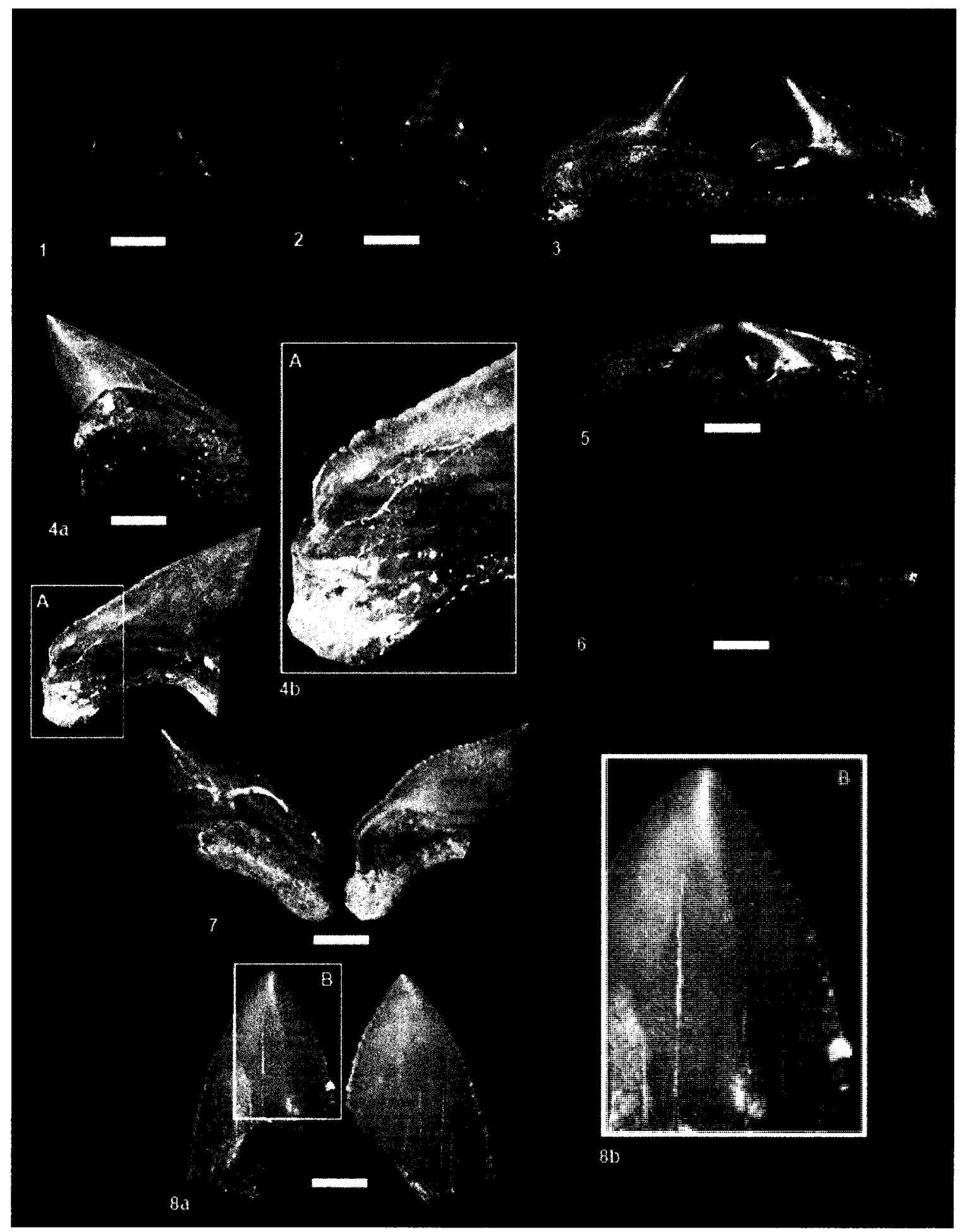




\section{PLATE III}

Figure 1: Archaeolamna sp. left parasymphyseal tooth (MM V-2932), lingual (left) and labial (right) views

Figure 2: Archaeolamna sp. right intermediate tooth (MM V-2933), lingual (left) and labial (right) views

Figure 3: Archaeolamna sp. anterior tooth (MM V-2934), lingual (left) and labial (right) views

Figure 4: Archaeolamna sp. anterior tooth (MM V-2935), lingual (left) and labial (right) views

Figure 5a: Archaeolamna sp. left lateral tooth (MM V-2936), lingual (left) and labial (right) views

Figure 5b (inset): Archaeolamna sp. left lateral tooth (MM V-2936), magnification of longitudinal folds of enamel on labial basal crown surface

Figure 6a: Archaeolamna sp. left distal-lateral tooth (MM V-2937), lingual (left) and labial (right) views

Figure $6 \mathrm{~b}$ (inset): Archaeolamna sp. left distal-lateral tooth (MM V-2937), magnification of longitudinal folds of enamel on labial basal crown surface

Figure 7: Cretalamna appendiculata left(?)anterior tooth (MM V-2938), lingual (left) and labial (right) views

Figure 8: Cretalamna appendiculata anterior tooth (MM V-2939), lingual (left) and labial (right) views

Figure 9: Cretoxyrhina mantelli anterior tooth (MM V-3018), lingual (left) and labial (right) views. Specimen collected from the Little Woody River locality.

Scale bars equal $2 \mathrm{~mm}$ (for Fig.s 1-8); $1 \mathrm{~cm}$ for Fig. 9 


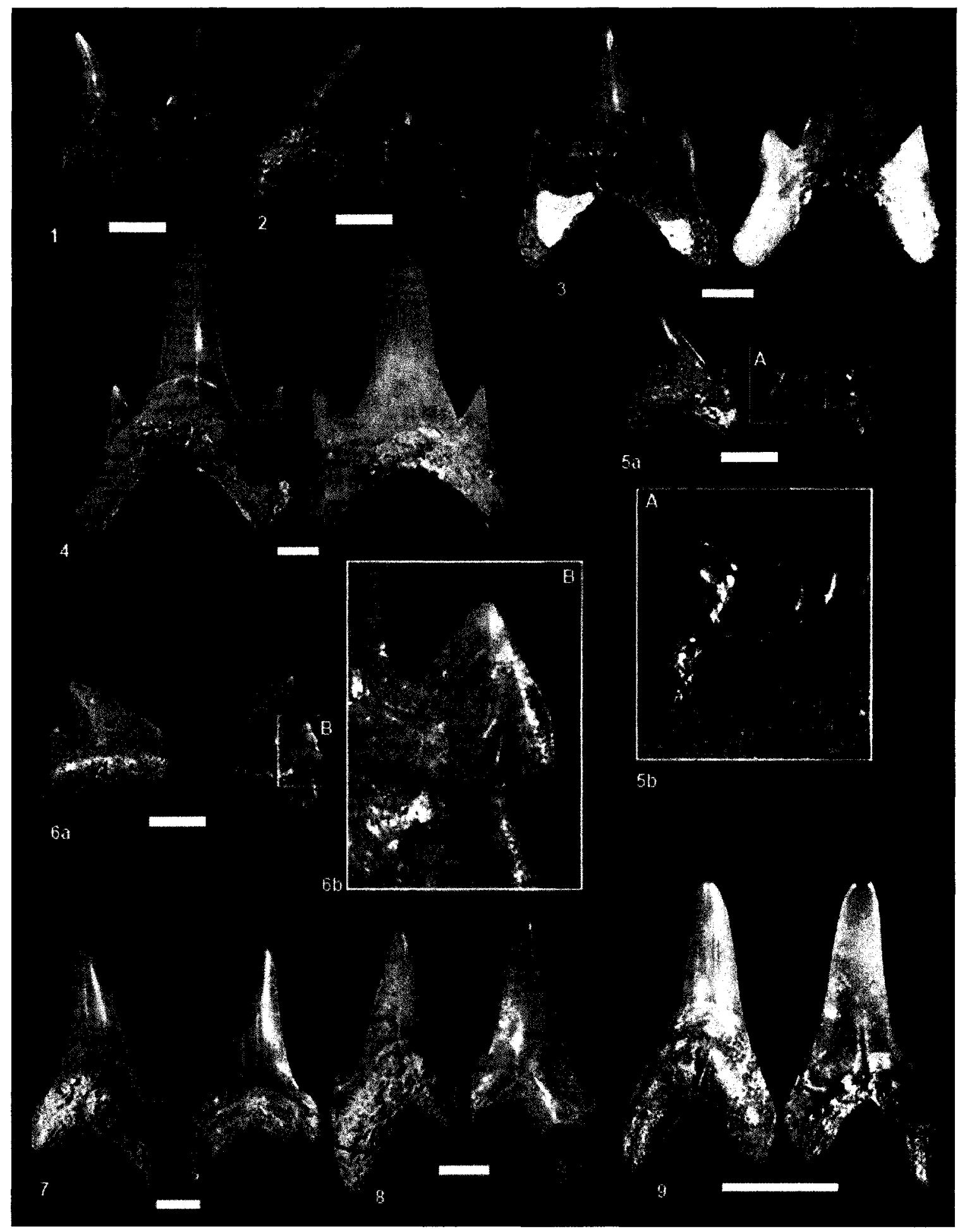




\section{PLATE IV}

Figure 1: "Cretoxyrhinid A" left anterolateral tooth (MM V-2940), labial (left) and lingual (right) views

Figure 2: "Cretoxyrhinid A" left anterolateral tooth (MM V-2941), labial (left) and lingual (right) views

Figure 3: "Cretoxyrhinid B" right(?) anterolateral tooth (MM V-2942), labial (left) and lingual (right) views

Figure 4: "Cretoxyrhinid B" right(?) anterolateral tooth (MM V-2943), labial (left) and lingual (right) views

Figure 5: "Cretoxyrhinid C" right anterolateral tooth (MM V-2944), labial (left) and lingual (right) views

Figure 6: Carcharias amonensis right(?) anterior tooth (MM V-2945), labial (left) and lingual (right) views

Figure 7: Carcharias amonensis left anterior tooth (MM V-2946), labial (left) and lingual (right) views

Figure 8: Carcharias amonensis left anterior tooth (MM V-2947), labial (left) and lingual (right) views

Figure 9: Carcharias amonensis left anterolateral tooth (MM V-2948), labial (left) and lingual (right) views

Figure 10: Carcharias amonensis left distal-lateral tooth (MM V-2949), labial (left) and lingual (right) views

Figure 11: Carcharias amonensis right distal-lateral tooth (MM V-2950), labial (left) and lingual (right) views

Scale bars equal $2 \mathrm{~mm}$ 


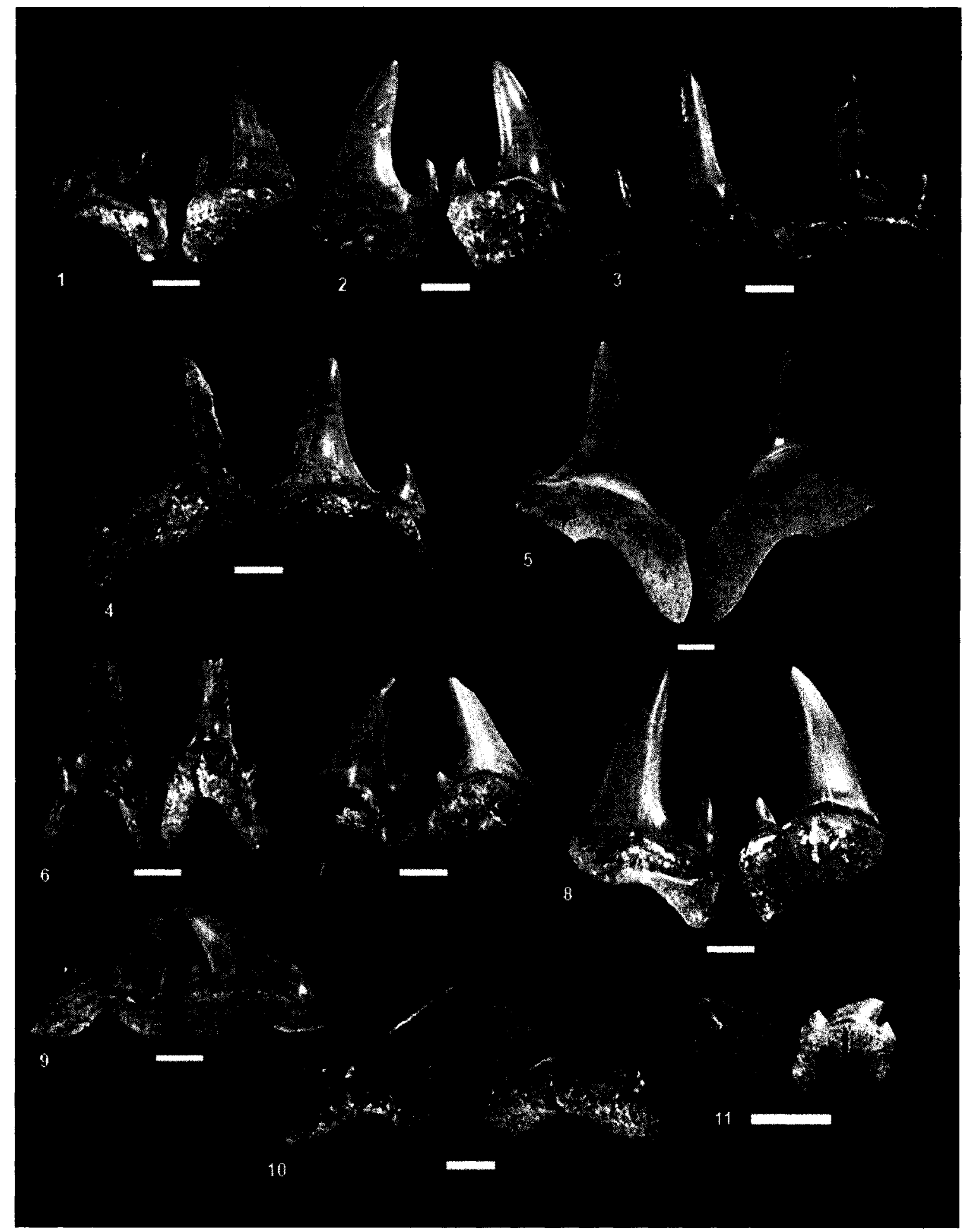




\section{PLATE V}

Figure 1: Carcharias cf. C. saskatchewanensis left anterolateral tooth (MM V-2951), labial (left) and lingual (right) views

Figure 2a: Carcharias $\mathrm{cf}$. C. saskatchewanensis left anterolateral tooth (MM V-2952), labial (left) and lingual (right) views

Figure 2b (inset): Carcharias $\mathrm{cf}$. C. saskatchewanensis left anterolateral tooth (MM $\mathrm{V}-2952$ ), magnification of short longitudinal ridges of enamel on labial basal crown surface (mesial cusplet)

Figure 2c (inset): Carcharias cf. C. saskatchewanensis left anterolateral tooth (MM V2952), magnification of short longitudinal ridges of enamel on labial basal crown surface (distal cusplet)

Figure 3: Carcharias cf. C. saskatchewanensis right anterolateral tooth (MM V-2953), labial (left) and lingual (right) views

Figure 4: Carcharias cf. C. saskatchewanensis right anterolateral tooth with pathologically split cusp (MM V-2954), labial (left) and lingual (right) views

Figure 5: Carcharias sp. A right anterolateral(?) tooth (MM V-2955), labial (left) and lingual (right) views

Figure 6: Carcharias sp. B anterior tooth (MM V-2956), labial (left) and lingual (right) views

Scale bars equal $2 \mathrm{~mm}$ 


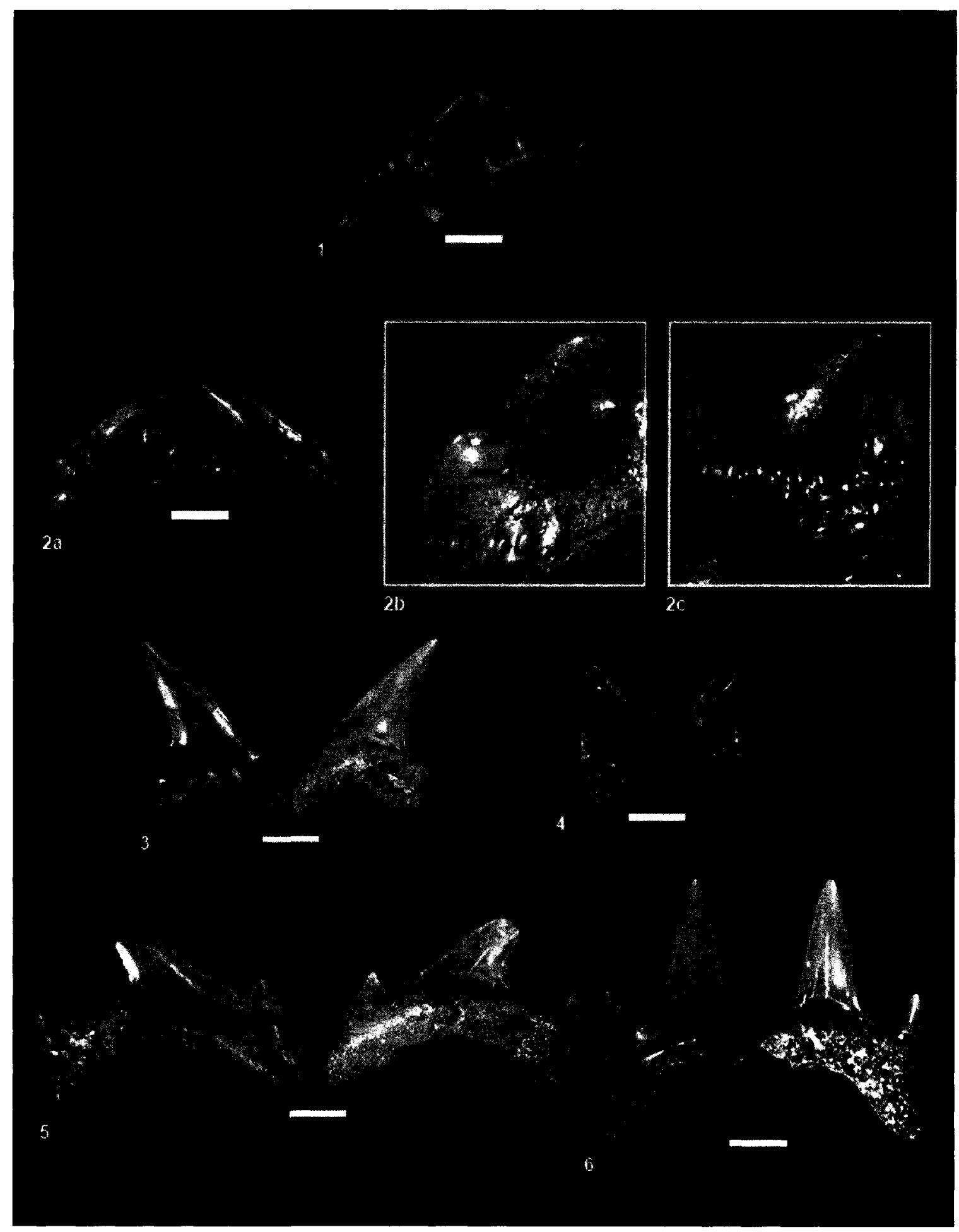




\section{PLATE VI}

Figure 1: unidentified caturid - halved centra (clockwise from upper left - MM V2957, MM V-2958, MM V-2959, MM V-2960), lateral views

Figure 2: unidentified caturid - whole centrum (MM V-2961), anterior (left), left lateral (centre) and posterior (right) views

Figure 3: unidentified caturid - generalized scale (MM V-2962), lateral (left) and medial (right) views

Figure 4: unidentified caturid - lateral line scale scale (MM V-2963), lateral (left) and medial (right) views

Figure 5: Pycnodontidae incertae sedis - bone fragment with ornamented, enameloid surface (MM V-2964), lateral view

Figure 6: Protosphyraena sp. teeth (clockwise from centre - MM V-2965, MM V2966, MM V-2967)

Figure 7: Xiphactinus audax tooth (MM V-2968)

Figure 8: Xiphactinus audax tooth (MM V-2969)

Figure 9: Unidentified ichthyodectid vertebra (MM V-2970), left lateral view

Figure 10: Elopopsis sp. right tooth (MM V-2971), mesial (left) and lingual (right) views

Scale bars equal $2 \mathrm{~mm}$ 


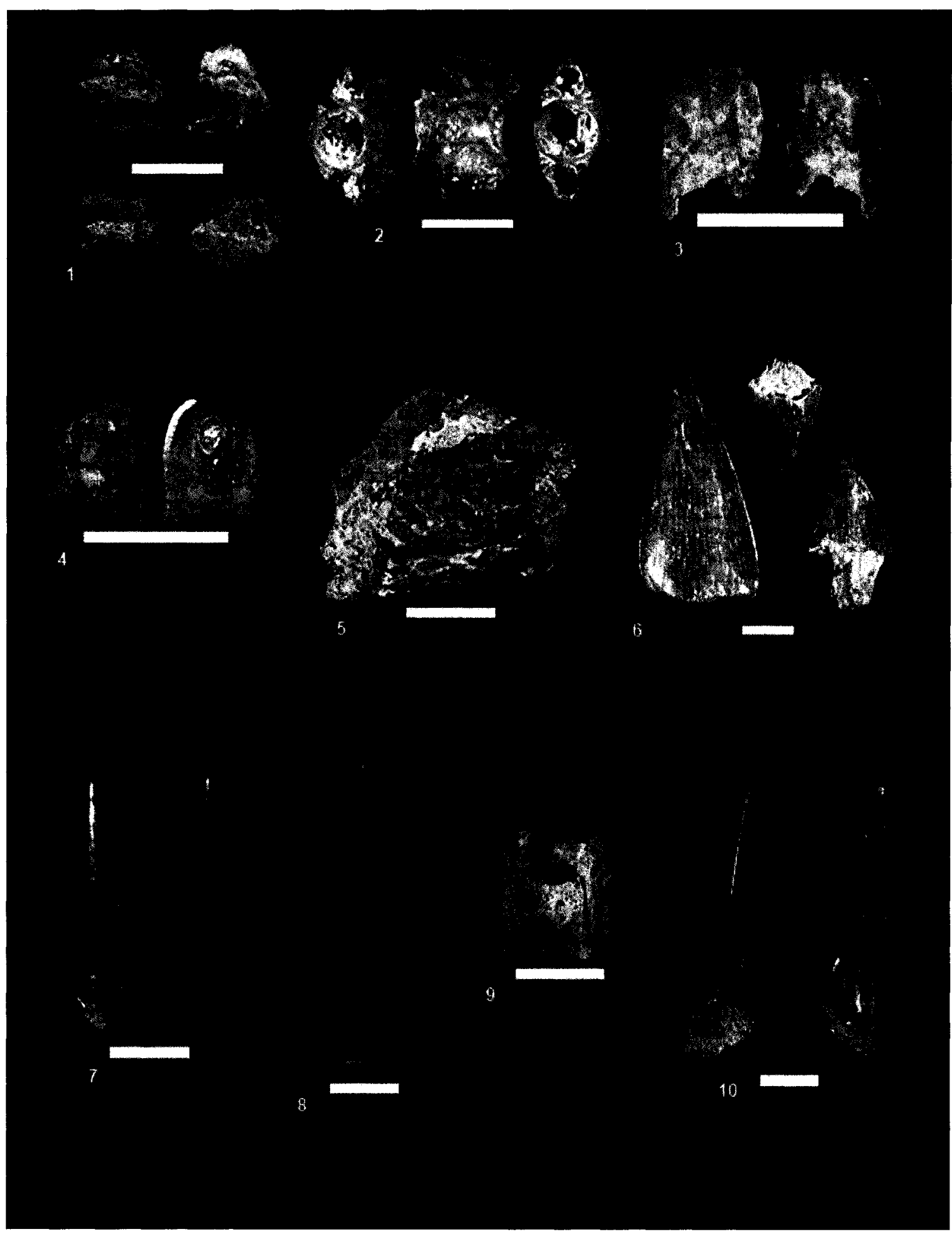




\section{PLATE VII}

Figure 1: unidentified salmoniform vertebrae (MM V-2972, left; MM V-2973, right)

Figure 2: unidentified salmoniform basioccipital (MM V-2974), left lateral (left) and dorsal (right) views

Figure 3: Enchodus cf. E. gladiolus tooth (MM V-2975)

Figure 4: Enchodus cf. E. gladiolus tooth (MM V-2976), lateral (left) and mesial (right) views

Figure 5: Enchodus cf. E. gladiolus left palatine (MM V-2977), medial (top) and lateral (bottom) views

Figure 6: Enchodus cf. E. petrosus(?) teeth (MM V-2978, left; MM V-2979, right)

Figure 7: Enchodus cf. E. petrosus(?) left palatine (MM V-2980), medial (left) and lateral (right) views

Figure 8: Enchodus cf. E. shumardi teeth (MM V-2981, left; MM V-2982, right)

Figure 9: Enchodus cf. E. shumardi left palatine (MM V-2983), lateral view

Scale bars equal 2 mm (Fig. 1-4, 6-9); 4 mm (Fig. 5) 
1
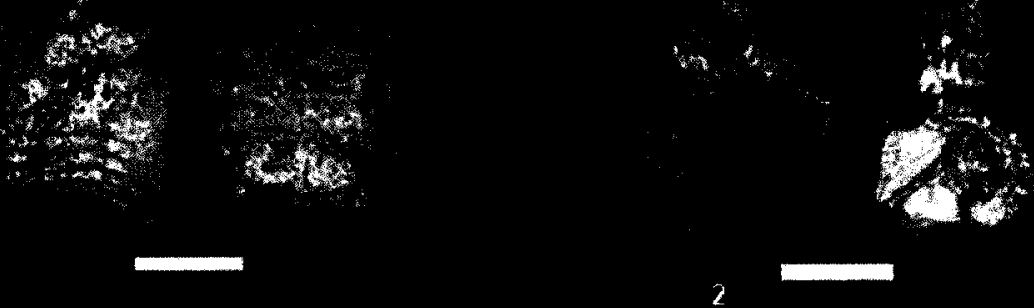

1

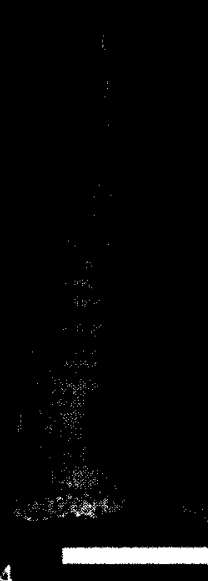

3

4
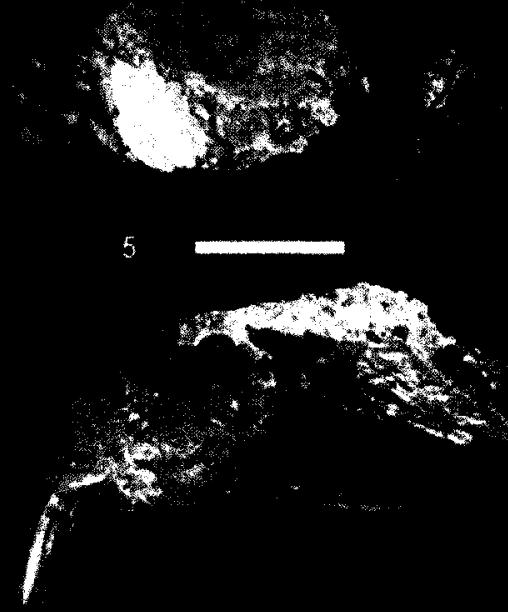

.

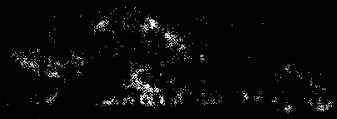

6
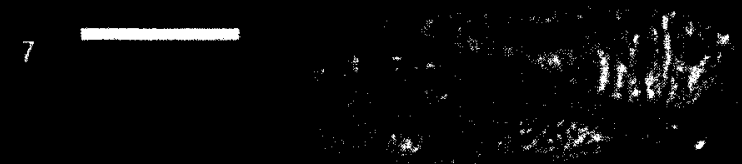


\section{PLATE VIII}

Figure 1: Enchodus sp. left ectopterygoid (MM V-2984), medial (left) and lateral (right) views

Figure 2: Enchodus sp. dentary fragments (MM V-2985, top; MM V-2986, bottom)

Figure 3: Enchodus sp. jaw fragments (MM V-2987), lateral (top) and medial (bottom) views

Figure 4: Enchodus sp. scale (MM V-2988), dorsal (left), oblique lateral (centre) and ventral (right) views

Figure 5: Anguilliform cf. unidentified anguilliform single right unfused neural arch (MM V-2989), medial (left) and lateral (right) views

Figure 6: Anguilliform cf. unidentified anguilliform single right unfused neural arch (MM V-2990), medial (left) and lateral (right) views

Figure 7: Anguilliform cf. unidentified anguilliform single left unfused neural arch (MM V-2991), medial (left) and lateral (right) views

Figure 8: Anguilliform cf. unidentified anguilliform single left unfused neural arch (MM V-2992), medial (left) and lateral (right) views

Scale bars equal $2 \mathrm{~mm}$ 


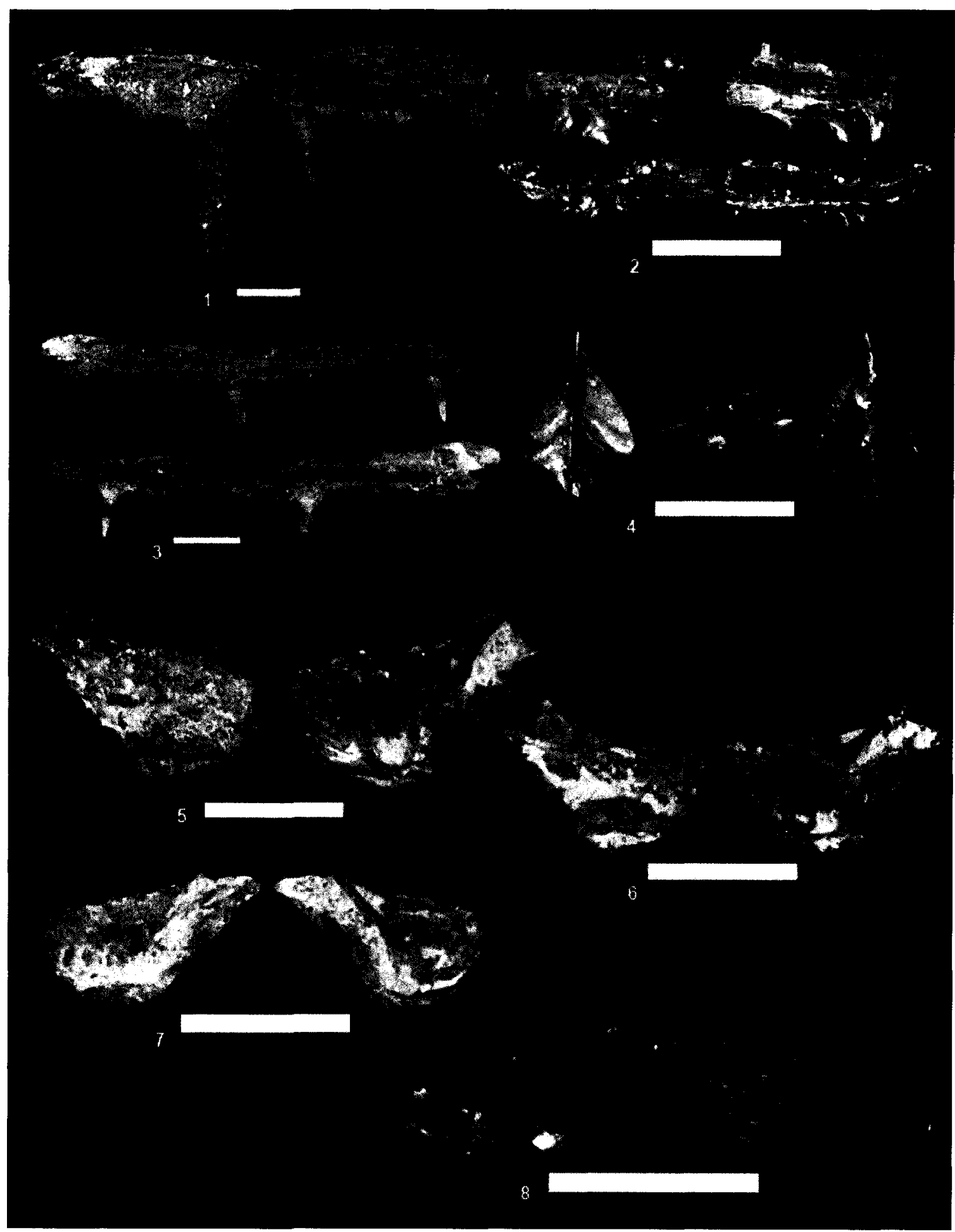




\section{PLATE IX}

Figure 1: unidentified basal euteleost left dentary (MM V-2993), medial (top) and lateral (bottom) views

Figure 2a: unidentified basal euteleost right dentary (MM V-2994), medial (top) and lateral (bottom) views

Figure 2b: unidentified basal euteleost right dentary (MM V-2994), magnified view of the medial side of the anterior end of the dentary, showing broken bases of teeth and symphysis

Figure 3: unidentified basal euteleost left hyomandibular (MM V-2995), lateral (left) and medial (right) views

Figure 4: unidentified basal euteleost left hyomandibular (MM V-2996), lateral (left) and medial (right) views

Figure 5: unidentified basal euteleost right hyomandibular (MM V-2997), lateral (left) and medial (right) views

Figure 6a: unidentified basal euteleost maxillary fragments (clockwise from upper left - MM V-2998, MM V-2999, MM V-3000), medial view

Figure 6b: unidentified basal euteleost maxillary fragment (MM V-3000), magnified view of the bottommost fragment from the previous fragment, showing broken bases of teeth

Figure 7: unidentified basal euteleost preopercular (MM V-3001)

Scale bars equal $2 \mathrm{~mm}$ 


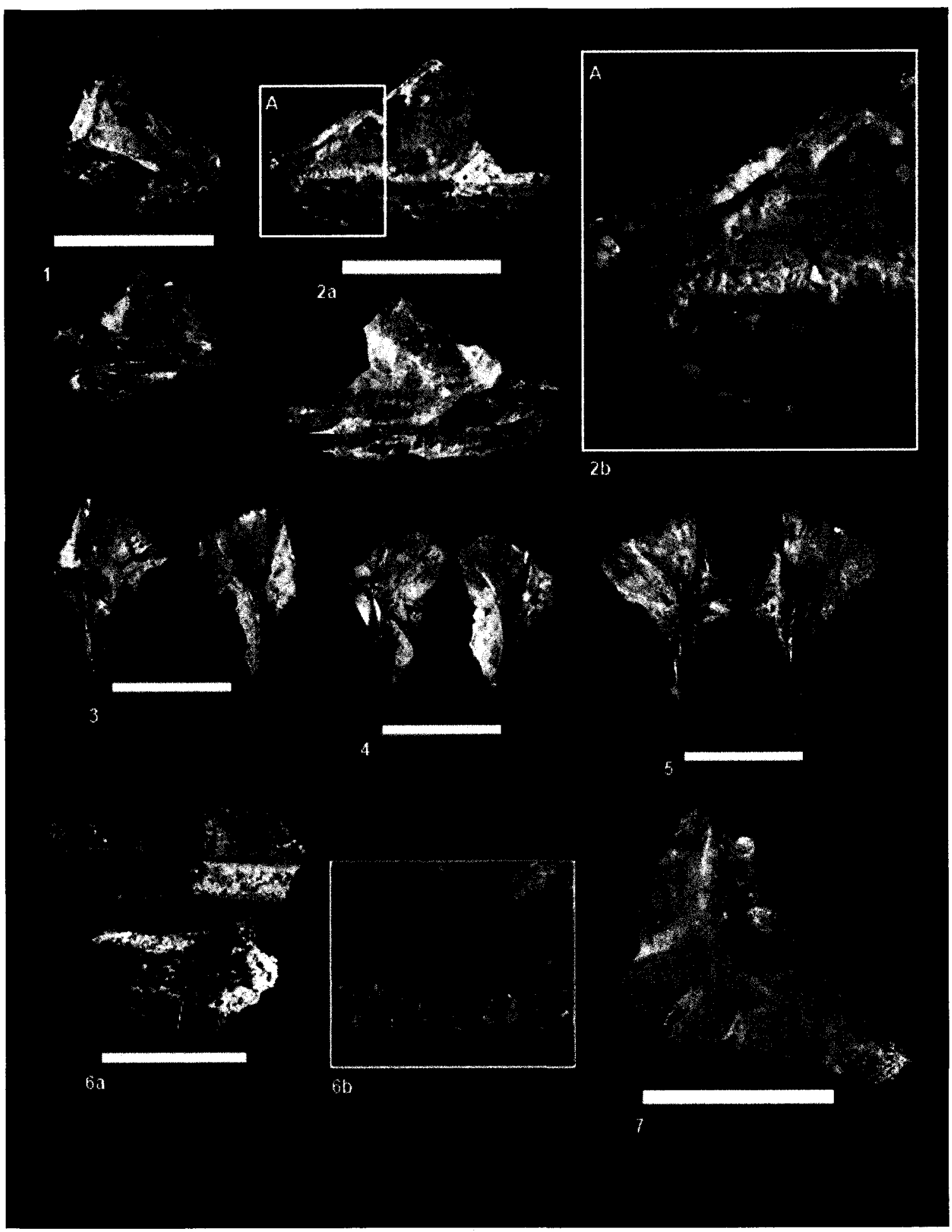




\section{PLATE X}

Figure 1: unidentified basal euteleost right angulo-articular (MM V-3002), medial (left) and lateral (right) views

Figure 2: unidentified basal euteleost left angulo-articular (MM V-3003), medial (left) and lateral (right) views

Figure 3: unidentified basal euteleost right quadrate (MM V-3004), medial (left) and lateral (right) views

Figure 4: unidentified basal euteleost right quadrate (MM V-3005), medial (left) and lateral (right) views

Figure 5: unidentified basal euteleost supraoccipital (MM V-3006), dorsal view

Figure 6: "Teleost A" teeth (from left - MM V-3007, MM V-3008, MM V-3009)

Figure 7: "Teleost A" jaw fragment (MM V-3010), lateral(?) (top) and occlusal (bottom) views

Figure 8: "Teleost A" jaw fragment, partially preserved within a coprolitic mass (MM V-3011), oblique occlusal view

Figure 9: “Teleost B" tooth (MM V-3012), mesial(?) (left) and lateral (right) views

Scale bars equal $2 \mathrm{~mm}$ 


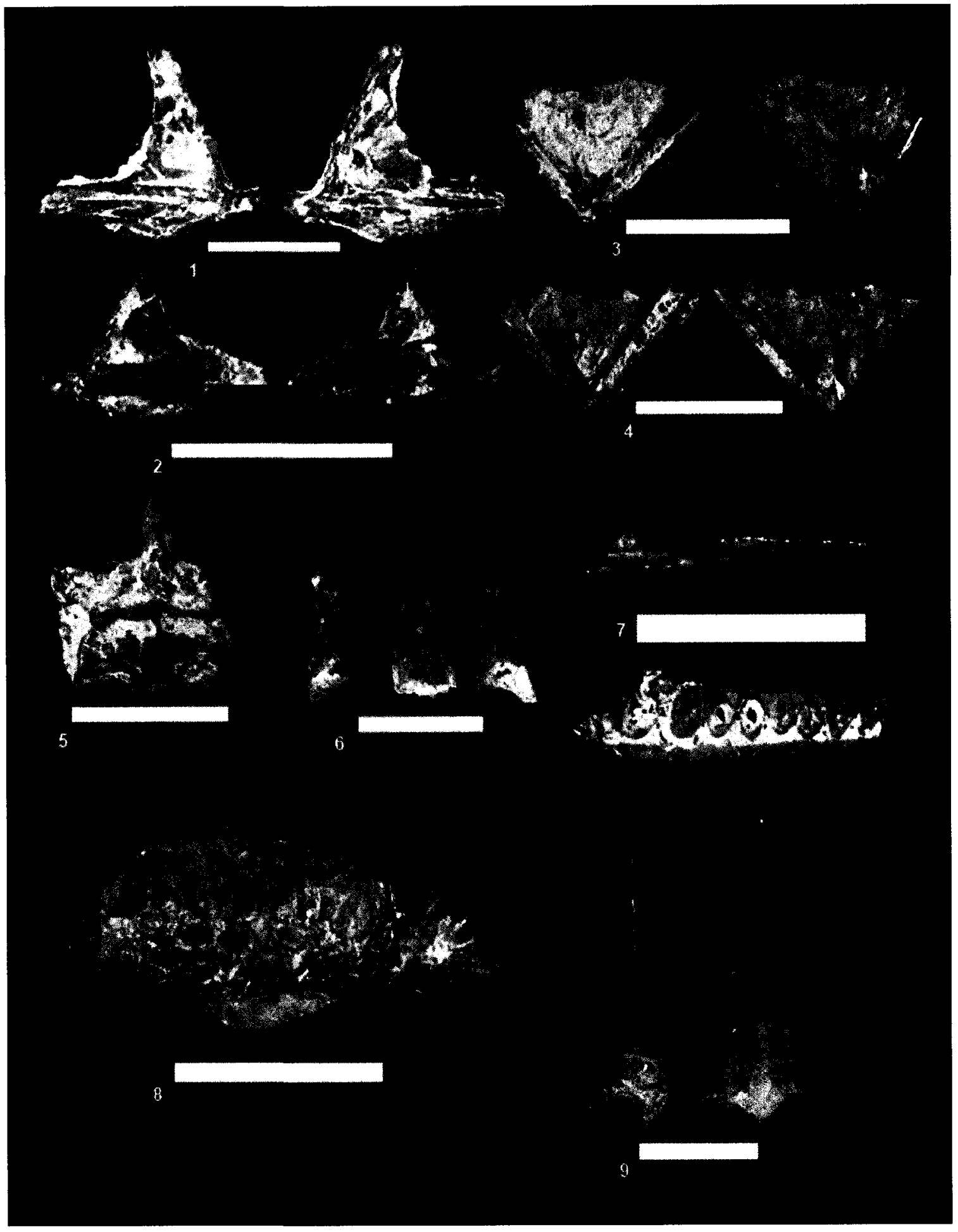




\section{PLATE XI}

Figure 1: unidentified hesperornithiform tooth (P 3015.2), medial (left) and lateral (right) views. Specimen collected as float from along the Bainbridge River between localities BR-3 and BR-2 locality.

Figure 2: unidentified hesperornithiform bone fragment ( $P$ 3015.3). Specimen collected as float from along the Bainbridge River between localities BR-3 and BR-2 locality.

Figure 3: unidentified turtle marginal scute (MM V-3013), dorsal, proximal, distal and ventral views (from left to right). Notice smooth groove running across the distal end

Figure 4: Brachauchenius sp. tooth impression (MM V-3020)

Figure 5: unidentified plesiosaur phalangeal element (P 3015.4). Specimen collected as float from along the Bainbridge River between localities BR-3 and BR-2 locality.

Figure 6: vertebrate microcoprolite (MM V-3014), under direct light (left) and low angle lighting highlighting a slightly spiraled shaped (right)

Figure 7: vertebrate microcoprolites containing distinct vertebrate bone inclusions (MM V-3015, left; MM V-3016, right), including an osteichthyan vertebra (left) and the caudal end of an osteichthyan basioccipital (right)

Figure 8: vertebrate enterospira (MM V-3017)

Scale bars equal $2 \mathrm{~mm}$ (Fig. 1, 6-8); $6 \mathrm{~mm}$ (Fig. 2, 5); $1 \mathrm{~cm}$ (Fig. 3-4) 


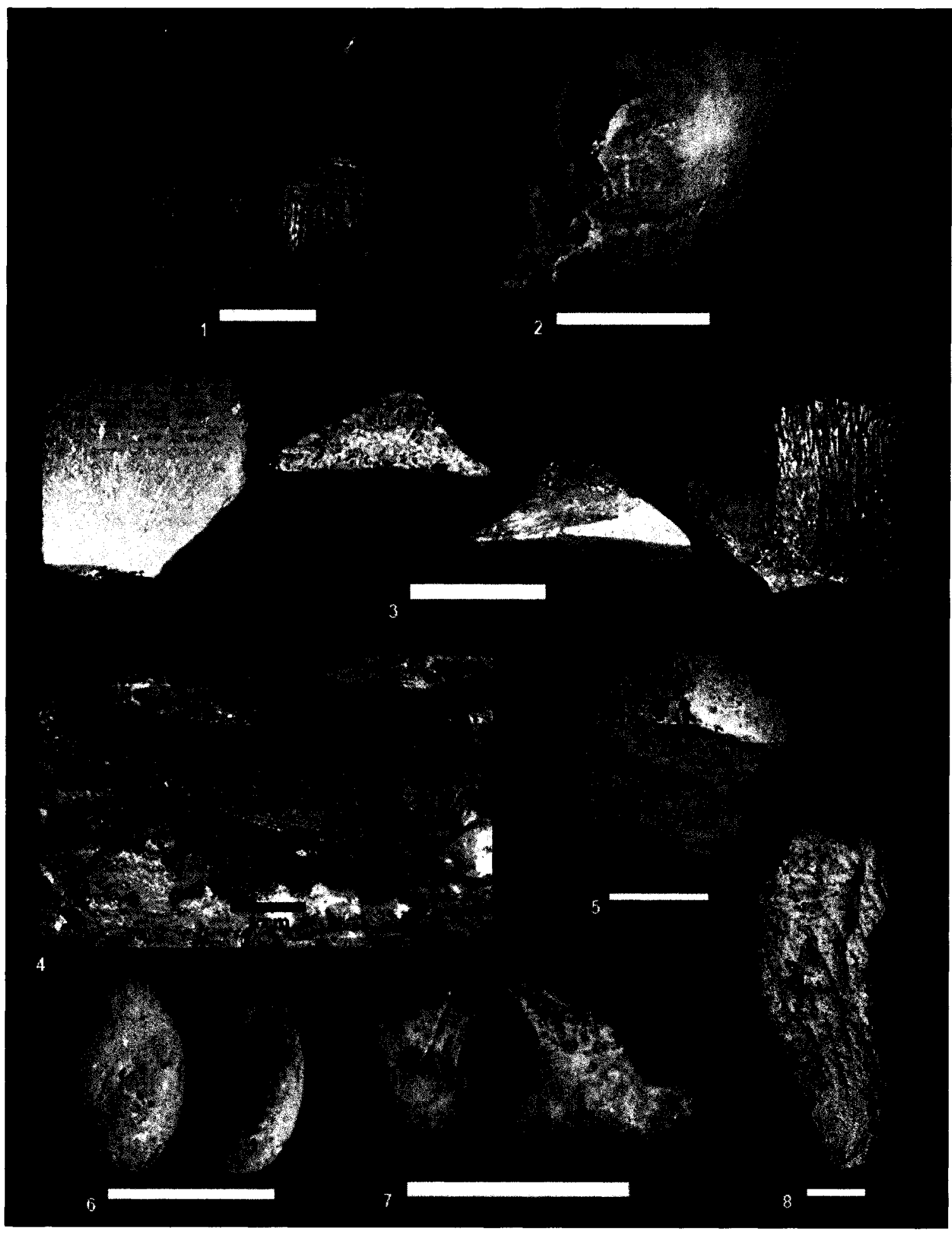


APPENDICES 
APPENDIX I:

VAN DER VOORT LOCALITY CALCARENITE SAMPLE MEASUREMENTS 


\begin{tabular}{|c|c|c|c|c|}
\hline \multicolumn{5}{|c|}{ Van Der Voort Locality Calcarenite Sample Measurements } \\
\hline \multirow[b]{2}{*}{ Specimen \# } & \multicolumn{3}{|c|}{ Pre-acid treatment } & \multirow{2}{*}{$\begin{array}{c}\begin{array}{c}\text { Post-acid } \\
\text { treatment }\end{array} \\
\begin{array}{c}\text { Dry weight of } \\
\text { recovered, } \\
\text { insoluable clasts } \\
\text { (g) }\end{array} \\
\end{array}$} \\
\hline & $\begin{array}{c}\text { Weight } \\
\text { (g) }\end{array}$ & $\begin{array}{l}\text { Volume } \\
\text { (displacement; } \\
\text { in } \mathrm{mL} \text { ) }\end{array}$ & Notes & \\
\hline VdV001 & 1580 & 635 & & 106.6 \\
\hline VdV002 & 1652 & 635 & & 51.5 \\
\hline VdV003 & $412 *$ & $\sim 250 * *^{2}$ & $\begin{array}{l}\text { *Initial weight includes } \\
\text { box. Box weighed } 17 \mathrm{~g} \text {. } \\
412-17=395 \mathrm{~g} \text { as total } \\
\text { specimen weight. } \\
{ }^{2} \text { this specimen was very } \\
\text { crumbly; volume is very } \\
\text { approximate. }\end{array}$ & 49.2 \\
\hline VdV004 & 1220 & 480 & & 34.7 \\
\hline VdV005 & 591 & 250 & & 18.1 \\
\hline
\end{tabular}


APPENDIX II:

SPECIMEN INVENTORY 


\begin{tabular}{|c|c|c|c|}
\hline \multicolumn{4}{|c|}{ Specimen Inventory } \\
\hline \multicolumn{2}{|c|}{ Sample \#: BR-3 float - Pt. 1 of 2} & \multicolumn{2}{|r|}{ Sieve Size: No. 10} \\
\hline Specimen \# & Element & Count & Notes \\
\hline \multirow{2}{*}{\multicolumn{4}{|c|}{ 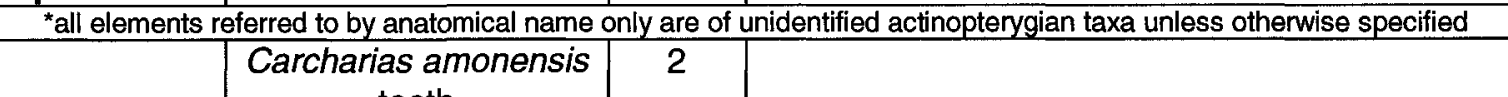 }} \\
\hline & & & \\
\hline & Carcharias sp. B teeth & 1 & \\
\hline & Carcharias sp. C teeth & 2 & \\
\hline & Coprolite fragments & 32 & \\
\hline & Coprolites & 34 & \\
\hline & $\begin{array}{l}\text { Elopopsis sp. tooth } \\
\text { base }\end{array}$ & 1 & \\
\hline & $\begin{array}{c}\text { Enchodus sp. teeth \& } \\
\text { palatine }\end{array}$ & 3 & 2 teeth, 1 palatine \\
\hline & Hybodus butleri teeth & 1 & \\
\hline P 3015.4 & $\begin{array}{l}\text { Plesiosaur phalange } \\
\text { fragment }\end{array}$ & 1 & Plate XI - Fig. 5 \\
\hline \multirow[t]{6}{*}{ P 3015.1} & Ptychodus sp. teeth & 1 & Plate I - Fig. 2 \\
\hline & $\begin{array}{c}\text { Squalicorax } \\
\text { falcatus/curvatus } \\
\text { teeth }\end{array}$ & 1 & \\
\hline & $\begin{array}{l}\text { Squalicorax volgensis } \\
\text { teeth }\end{array}$ & 2 & \\
\hline & "Teleost A" fish teeth & 1 & \\
\hline & $\begin{array}{l}\text { Unidentified compact- } \\
\text { shaped bones \& } \\
\text { fragments }\end{array}$ & 17 & Mostly tetrapod-like in appearance (vs. piscine) \\
\hline & $\begin{array}{l}\text { Unidentified elongate- } \\
\text { shaped bones \& } \\
\text { fragments }\end{array}$ & 5 & Mostly tetrapod-like in appearance (vs. piscine) \\
\hline \multirow[t]{9}{*}{ P 3015.3} & $\begin{array}{l}\text { Unidentified plate- } \\
\text { shaped bird bone } \\
\text { fragments }\end{array}$ & 2 & Plate XI - Fig. 2 \\
\hline & $\begin{array}{l}\text { Unidentified plate- } \\
\text { shaped bones \& } \\
\text { fragments }\end{array}$ & 18 & Mostly tetrapod-like in appearance (vs. piscine) \\
\hline & $\begin{array}{l}\text { Unidentified shark } \\
\text { tooth fragments }\end{array}$ & 2 & \\
\hline & $\begin{array}{l}\text { Vertebrae - } \\
\text { Morphotype \#12 }\end{array}$ & 3 & $\begin{array}{l}\text { This morphotype is BR-3 specific: appears } \\
\text { osteichthyian; anterior face of centrum almost } \\
\text { flat (vs. concave) }\end{array}$ \\
\hline & $\begin{array}{c}\text { Vertebrae - } \\
\text { Morphotype \#4 }\end{array}$ & 6 & \\
\hline & $\begin{array}{c}\text { Vertebrae - } \\
\text { unidentified shark }\end{array}$ & 1 & \\
\hline & $\begin{array}{l}\text { Vertebral fragments - } \\
\text { Morphotype \#8 }\end{array}$ & 1 & \\
\hline & $\begin{array}{l}\text { Vertebral fragments - } \\
\text { shark(?) }\end{array}$ & 6 & \\
\hline & $\begin{array}{l}\text { Vertebral fragments - } \\
\text { unidentified - } \\
\text { compact-shaped }\end{array}$ & 19 & \\
\hline
\end{tabular}


Specimen Inventory

\begin{tabular}{|c|c|c|c|}
\hline \multicolumn{4}{|c|}{ Specimen Inventory } \\
\hline \multicolumn{2}{|c|}{ Sample \#: BR-3 float - Pt. 2 of 2} & \multicolumn{2}{|r|}{ Sieve Size: No. 10} \\
\hline Specimen \# & Element & Count & Notes \\
\hline \multicolumn{4}{|c|}{ "all elements referred to by anatomical name only are of unidentified actinopterygian taxa unless otherwise specified } \\
\hline & $\begin{array}{c}\text { Vertebral fragments - } \\
\text { unidentified - plate- } \\
\text { shaped }\end{array}$ & 14 & \\
\hline & tal Count: & 176 & $\begin{array}{l}\text { *This sample was used in the comparative } \\
\text { taphonomic census }\end{array}$ \\
\hline
\end{tabular}




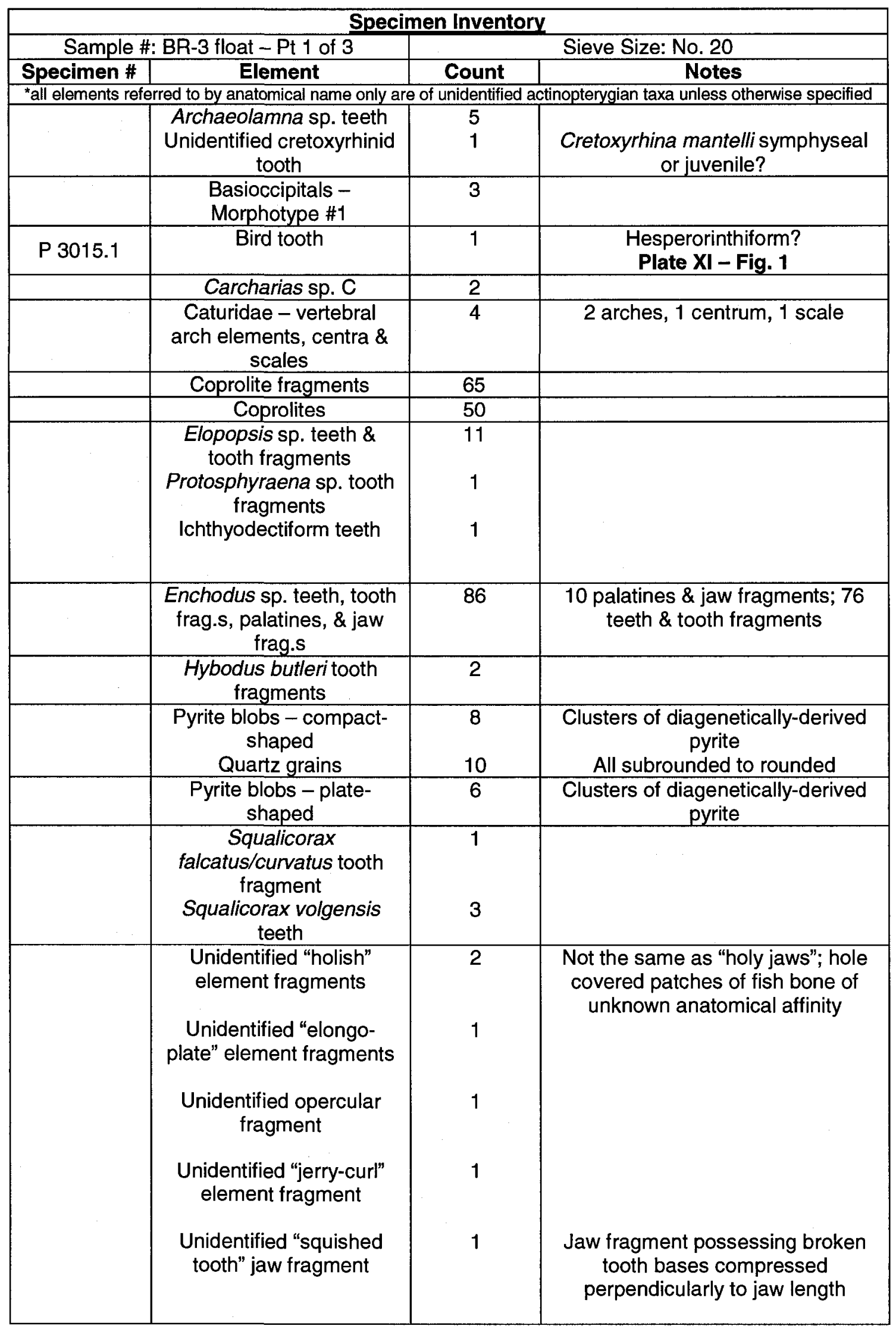




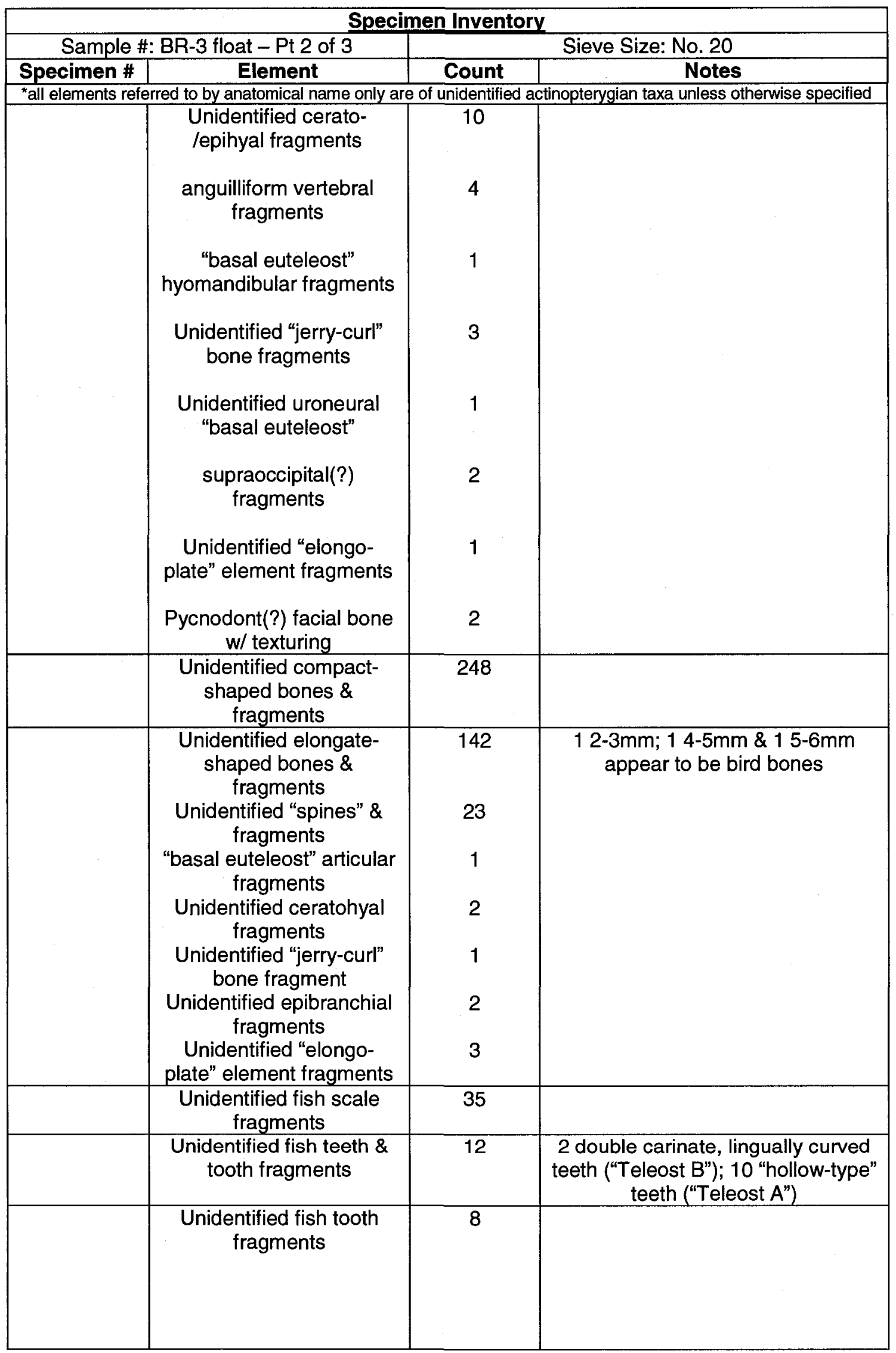




\begin{tabular}{|c|c|c|c|}
\hline \multicolumn{4}{|c|}{ Specimen Inventory } \\
\hline \multicolumn{2}{|c|}{ Sample \#: BR-3 float - Pt 3 of 3} & \multicolumn{2}{|r|}{ Sieve Size: No. 20} \\
\hline Specimen \# & Element & Count & Notes \\
\hline \multicolumn{4}{|c|}{ *all elements referred to by anatomical name only are of unidentified actinopterygian taxa unless otherwise specified } \\
\hline & $\begin{array}{l}\text { Unidentified opercular } \\
\text { fragments } \\
\text { "basal euteleost" } \\
\text { quadrate fragments } \\
\text { "basal euteleost" dentary } \\
\text { fragments }\end{array}$ & $\begin{array}{l}3 \\
3\end{array}$ & \\
\hline & $\begin{array}{c}\text { Unidentified plate-shaped } \\
\text { bones \& fragments }\end{array}$ & 494 & 3 3-4mm appear to be bird bones \\
\hline & $\begin{array}{l}\text { Unidentified shark tooth } \\
\text { fragments }\end{array}$ & 13 & \\
\hline & Vertebrae - fish & 21 & $\begin{array}{c}2 \text { MT\#1/\#2; } 1 \text { MT\#3; } 4 \text { MT\#4; } 4 \\
\text { MT\#6; } \\
\text { 6 MT\#8; } 4 \text { MT\#12 }\end{array}$ \\
\hline & $\begin{array}{l}\text { Vertebral fragments - } \\
\text { unidentified - compact- } \\
\text { shaped }\end{array}$ & 116 & \\
\hline & $\begin{array}{l}\text { Vertebral fragments - } \\
\text { unidentified - elongate- } \\
\text { shaped }\end{array}$ & 13 & \\
\hline & $\begin{array}{l}\text { Vertebral fragments - } \\
\text { unidentified - plate- } \\
\text { shaped }\end{array}$ & 198 & \\
\hline & Total Count: & 1629 & $\begin{array}{l}{ }^{*} \text { This sample was used in the } \\
\text { comparative taphonomic census }\end{array}$ \\
\hline
\end{tabular}




\begin{tabular}{|c|c|c|c|}
\hline \multicolumn{4}{|c|}{ Specimen Inventory } \\
\hline \multicolumn{2}{|c|}{ Sample \# MB Museum - Pt 1 of 3} & \multicolumn{2}{|r|}{ Sieve size: $n / a$} \\
\hline Specimen \# & Element & Count & Notes \\
\hline \multicolumn{4}{|c|}{ *all elements referred to by anatomical name only are of unidentified actinopterygian taxa unless otherwise specified } \\
\hline & Archaeolamna sp. teeth & 19 & \\
\hline MM V-2932 & Archaeolamna sp. tooth & 1 & Plate III - Fig. 1 \\
\hline MM V-2936 & Archaeolamna sp. tooth & 1 & Plate III - Fig. 5 \\
\hline \multirow[t]{3}{*}{ MM V-2937 } & Archaeolamna sp. tooth & 1 & Plate III - Fig. 6 \\
\hline & $\begin{array}{c}\text { Basioccipital - } \\
\text { Morphotype \#1 } \\
\text { Vertebrae - } \\
\text { Morphotype \#5 } \\
\text { Vertebrae - } \\
\text { Morphotype \#8 } \\
\text { Vertebral fragment - } \\
\text { unidentified } \\
\text { Vertebrae - } \\
\text { unrecognized } \\
\text { morphotype }\end{array}$ & $\begin{array}{l}1 \\
1 \\
1 \\
1\end{array}$ & \\
\hline & $\begin{array}{l}\text { Carcharias amonensis } \\
\text { teeth }\end{array}$ & 24 & \\
\hline MM V-2946 & $\begin{array}{l}\text { Carcharias amonensis } \\
\text { tooth }\end{array}$ & 1 & Plate IV - Fig. 7 \\
\hline MM V-2947 & $\begin{array}{l}\text { Carcharias amonensis } \\
\text { tooth }\end{array}$ & 1 & Plate IV - Fig. 8 \\
\hline \multirow[t]{3}{*}{ MM V-2950 } & $\begin{array}{l}\text { Carcharias amonensis } \\
\text { tooth }\end{array}$ & 1 & Plate IV - Fig. 11 \\
\hline & Carcharias sp. A teeth & 4 & $\begin{array}{l}\text { Wide set cusplets, very vertical (vs. } \\
\text { divergent) }\end{array}$ \\
\hline & Carcharias sp. B teeth & 2 & $\begin{array}{l}\text { Root lobes have distinct "corners" } \\
\text { beneath lateral cusplets. }\end{array}$ \\
\hline \multirow[t]{2}{*}{ MM V-2956 } & Carcharias sp. B tooth & 1 & Plate V - Fig. 6 \\
\hline & $\begin{array}{l}\text { Carcharias sp. C teeth } \\
\text { (cf. C. } \\
\text { saskatchewanensis) }\end{array}$ & 2 & $\begin{array}{l}\text { Small enameloid ridges on one side or } \\
\text { other of crown base. }\end{array}$ \\
\hline MM V-2952 & $\begin{array}{l}\text { Carcharias sp. C tooth } \\
\text { (cf. C. } \\
\text { saskatchewanensis) }\end{array}$ & 1 & Plate V - Fig 2 \\
\hline MM V-2953 & $\begin{array}{l}\text { Carcharias sp. C tooth } \\
\text { (cf. C. } \\
\text { saskatchewanensis) }\end{array}$ & 1 & Plate V - Fig. 3 \\
\hline MM V-2938 & $\begin{array}{c}\text { Cretalamna } \\
\text { appendiculata tooth }\end{array}$ & 1 & Plate III - Fig. 7 \\
\hline \multirow[t]{4}{*}{ MM V-2939 } & $\begin{array}{c}\text { Cretalamna } \\
\text { appendiculata tooth }\end{array}$ & 1 & Plate III - Fig. 8 \\
\hline & $\begin{array}{c}\text { Cretalamna } \\
\text { appendiculata tooth }\end{array}$ & 1 & \\
\hline & Elopopsis sp. teeth & 14 & \\
\hline & $\begin{array}{l}\text { Enchodus palatine \& } \\
\text { palatine fragments }\end{array}$ & 7 & $\begin{array}{c}6 \text { unidentifiable to species; } 1 \text { similar to } E \text {. } \\
\text { shumardi }\end{array}$ \\
\hline MM V-2977 & Enchodus palatine & 1 & Cf. E. gladiolus; Plate VII - Fig. 5 \\
\hline
\end{tabular}




\begin{tabular}{|c|c|c|c|}
\hline \multicolumn{4}{|c|}{ Specimen Inventory } \\
\hline \multicolumn{2}{|c|}{ Sample \# MB Museum - Pt 2 of 3} & \multicolumn{2}{|r|}{ Sieve size: $n / a$} \\
\hline Specimen \# & Element & Count & Notes \\
\hline \multirow{2}{*}{\multicolumn{4}{|c|}{\begin{tabular}{l|l|l|l} 
*all elements referred to by anatomical name only are of unidentified actinopterygian taxa unless otherwise specified \\
\end{tabular}}} \\
\hline & & & \\
\hline MM V-2975 & Enchodus tooth & 1 & Plate VII - Fig. 3 \\
\hline MM V-2976 & Enchodus tooth & 1 & Plate VII - Fig. 4 \\
\hline MM V-2981 & Enchodus tooth & 1 & Plate VII - Fig. 8, left \\
\hline \multirow[t]{2}{*}{ MM V-2982 } & Enchodus tooth & 1 & Plate VII - Fig. 8, right \\
\hline & $\begin{array}{l}\text { Extremely rounded } \\
\text { bone fragments }\end{array}$ & 2 & \\
\hline \multirow[t]{2}{*}{ MM V-2923 } & Hybodus butleri tooth & 1 & Plate I - Fig. 1 \\
\hline & $\begin{array}{c}\text { Possible } \\
\text { ichthyodectiform teeth }\end{array}$ & 5 & $\begin{array}{l}\text { Have relatively small central pulp cavity; } \\
\text { most possess a translucent, amber- } \\
\text { colored apex; quite conical (minimal } \\
\text { lateral compression); lack carinae }\end{array}$ \\
\hline MM V-2968 & ichthyodectiform teeth & 1 & Plate VI - Fig. 7 \\
\hline \multirow[t]{2}{*}{ MM V-2969 } & ichthyodectiform teeth & 1 & Plate VI - Fig. 8 \\
\hline & $\begin{array}{l}\text { Protosphyraena sp. } \\
\text { teeth }\end{array}$ & 2 & \\
\hline MM V-2965 & $\begin{array}{l}\text { Protosphyraena sp. } \\
\text { tooth }\end{array}$ & 1 & Plate VI - Fig. 6, centre \\
\hline MM V-2966 & $\begin{array}{l}\text { Protosphyraena sp. } \\
\text { tooth }\end{array}$ & 1 & Plate VI - Fig. 6, right \\
\hline \multirow[t]{3}{*}{ MM V-2967 } & $\begin{array}{l}\text { Protosphyraena sp. } \\
\text { tooth }\end{array}$ & 1 & Plate VI - Fig. 6, left \\
\hline & $\begin{array}{l}\text { Pycnodont(?) skull } \\
\text { bone fragment } \\
\text { Ornamented scale(?) } \\
\text { fragment }\end{array}$ & $\begin{array}{l}1 \\
1\end{array}$ & $\begin{array}{l}\text { Has small, knobbily texture akin to } \\
\text { texturing found on pycnodont facial } \\
\text { bones } \\
\text { Enchodus sp.? }\end{array}$ \\
\hline & $\begin{array}{l}\text { Small vial unexamined } \\
\text { fine material }\end{array}$ & $n / a$ & \\
\hline MM V-2930 & $\begin{array}{l}\text { Squalicorax falcatus } \\
\text { tooth }\end{array}$ & 1 & Plate II - Fig. 7 \\
\hline \multirow[t]{3}{*}{ MM V-2931 } & $\begin{array}{l}\text { Squalicorax falcatus } \\
\text { tooth fragment }\end{array}$ & 1 & Plate II - Fig. 8 \\
\hline & $\begin{array}{l}\text { Squalicorax falcatus } \\
\text { tooth fragment }\end{array}$ & 1 & \\
\hline & $\begin{array}{l}\text { Squalicorax volgensis } \\
\text { teeth \& tooth fragments }\end{array}$ & 13 & \\
\hline \multirow[t]{2}{*}{ MM V-2927 } & $\begin{array}{l}\text { Squalicorax volgensis } \\
\text { tooth }\end{array}$ & 1 & Plate II - Fig. 4 \\
\hline & "Teleost A" fish teeth & 6 & \\
\hline MM V-2940 & "Cretoxyrhinid A " tooth & 1 & $\begin{array}{c}\text { Similar to both Archaeolamna \& } \\
\text { Cretolamna, but possesses higher, } \\
\text { narrower \& much more erect cusplets. } \\
\text { Plate IV - Fig. } 1\end{array}$ \\
\hline MM V-2941 & "Cretoxyrhinid A " tooth & 1 & Plate IV - Fig. 2 \\
\hline
\end{tabular}




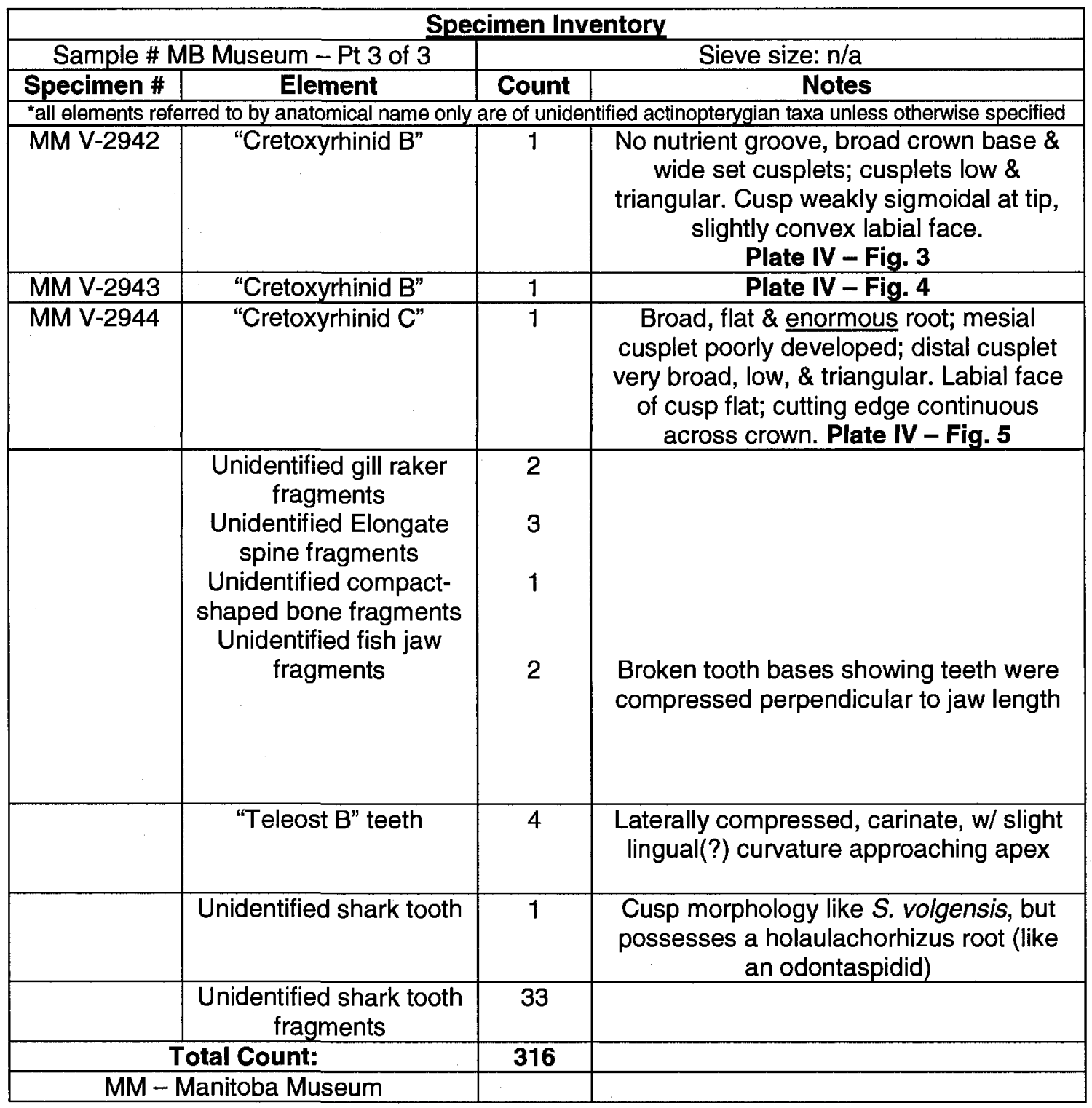




\begin{tabular}{|c|c|c|c|}
\hline \multicolumn{4}{|c|}{ Specimen Inventory } \\
\hline \multicolumn{2}{|c|}{ Sample \#: VdV001 - Pt. 1 of 3} & \multicolumn{2}{|r|}{ Sieve Size: No. 10} \\
\hline Specimen \# & Element & Count & Notes \\
\hline \multicolumn{4}{|c|}{ *all elements referred to by anatomical name only are of unidentified actinopterygian taxa unless otherwise specified } \\
\hline & Archaeolamna sp. teeth & 4 & \\
\hline MM V-2934 & Archaeolamna sp. tooth & 1 & Plate III - Fig. 3 \\
\hline \multirow[t]{6}{*}{ MM V-2935 } & Archaeolamna sp. tooth & 1 & Plate III - Fig. 4 \\
\hline & "oreo" bone fragments & 13 & $\begin{array}{l}\text { Plate-shaped frags of layered-looking } \\
\text { bone, w/ dark grey outer layers \& off- } \\
\text { white inner layer }\end{array}$ \\
\hline & $\begin{array}{l}\text { "basal euteleost" } \\
\text { dentaries }\end{array}$ & 1 & \\
\hline & $\begin{array}{l}\text { "basal euteleost" } \\
\text { articular }\end{array}$ & 1 & \\
\hline & $\begin{array}{c}\text { Basioccipital fragments } \\
\text { - Morphotype \#1 } \\
\text { Basioccipital fragments } \\
\text { - Morphotype \#3 } \\
\text { (salmoniform) }\end{array}$ & 4 & \\
\hline & $\begin{array}{c}\text { Carcharias amonensis } \\
\text { teeth }\end{array}$ & 2 & \\
\hline \multirow[t]{9}{*}{ MM V-2955 } & Carcharias sp. A teeth & 1 & Plate V-Fig. 5 \\
\hline & Caturid scales & 1 & \\
\hline & $\begin{array}{c}\text { Caturid vertebral } \\
\text { centrum }\end{array}$ & 1 & No arches preserved \\
\hline & $\begin{array}{l}\text { Cerato-/epihyal } \\
\text { fragments }\end{array}$ & 16 & \\
\hline & Coprolite fragments & 8 & \\
\hline & Coprolites & 28 & \\
\hline & $\begin{array}{c}\text { Dentary fragment w/ } \\
\text { tiny teeth }\end{array}$ & 1 & Elopopsis? \\
\hline & $\begin{array}{l}\text { Digested-looking bone } \\
\text { fragments }\end{array}$ & 8 & \\
\hline & Elopopsis sp. teeth & 4 & \\
\hline MM V-2984 & $\begin{array}{c}\text { Enchodus } \\
\text { ectopterygoid }\end{array}$ & 1 & $\begin{array}{l}\text { Broken during examination. } \\
\text { Plate VIII - Fig. } 1\end{array}$ \\
\hline \multirow[t]{3}{*}{ MM V-2980 } & Enchodus palatine & 1 & Cf. E. petrosus Plate VII - Fig. 7 \\
\hline & Enchodus palatine & 1 & Unidentified species, tooth vertical \\
\hline & Enchodus teeth & 9 & \\
\hline MM V-2978 & Enchodus tooth & 1 & Cf. E. petrosus, Plate VII - Fig. 6, left \\
\hline \multirow[t]{6}{*}{ MM V-2979 } & Enchodus tooth & 1 & Cf. E. petrosus, Plate VII - Fig. 6, right \\
\hline & Gill raker(?) fragments & 1 & \\
\hline & $\begin{array}{l}\text { "Basal euteleost" } \\
\text { hyomandibulars }\end{array}$ & 1 & \\
\hline & Mineral residues & $\mathrm{n} / \mathrm{a}$ & \\
\hline & Opercular fragments & 3 & \\
\hline & $\begin{array}{c}\text { Other fish scales \& } \\
\text { fragments }\end{array}$ & 33 & \\
\hline MM V-3011 & $\begin{array}{l}\text { Partially coprolite- } \\
\text { packed jaw fragment } \\
\text { ("Teleost A") }\end{array}$ & 1 & Plate X - Fig. 8 \\
\hline MM V-2954 & $\begin{array}{l}\text { Pathological shark } \\
\text { tooth (cf. C } \\
\text { saskatchewanensis }\end{array}$ & 1 & $\begin{array}{l}\text { Alternatively could be a distal } \\
\text { Archaeolamna tooth. } \\
\text { Plate V - Fig. } 4\end{array}$ \\
\hline
\end{tabular}




\begin{tabular}{|c|c|c|c|}
\hline \multicolumn{4}{|c|}{ Specimen Inventory } \\
\hline \multicolumn{2}{|c|}{ Sample \#: VdV001 - Pt. 2 of 3} & \multicolumn{2}{|r|}{ Sieve Size: No. 10} \\
\hline Specimen \# & Element & Count & Notes \\
\hline \multicolumn{4}{|c|}{ 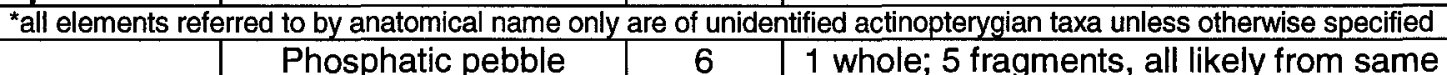 } \\
\hline & $\begin{array}{l}\text { Phosphatic pebble } \\
\text { fragments }\end{array}$ & 6 & $\begin{array}{c}1 \text { whole; } 5 \text { fragments, all likely from same } \\
\text { pebble }\end{array}$ \\
\hline & $\begin{array}{c}\text { Possible } \\
\text { ichthyodectiform tooth }\end{array}$ & 1 & Elongate, non-striated, non-carinate \\
\hline \multirow[t]{3}{*}{ MM V-3017 } & $\begin{array}{l}\text { Possible internal gut } \\
\text { cast (aka enterospira) }\end{array}$ & 1 & $\begin{array}{l}\text { Compositionally akin to a coprolite, but w/ } \\
\text { an unparalleled degree of surface } \\
\text { texturing ("ropey" in appearance) Plate XI } \\
\text { - Fig. } 8\end{array}$ \\
\hline & $\begin{array}{l}\text { "basal euteleost" } \\
\text { Preopercular fragments }\end{array}$ & 1 & \\
\hline & $\begin{array}{l}\text { pterygiophore } \\
\text { basipterygium }\end{array}$ & $\begin{array}{l}1 \\
1\end{array}$ & \\
\hline \multirow[t]{3}{*}{ MM V-2964 } & $\begin{array}{l}\text { Pycnodont(?) skull } \\
\text { bone fragment }\end{array}$ & 1 & $\begin{array}{c}\text { Has a small-scale, knobbily texture } \\
\text { reminiscent of the texturing of pycndont } \\
\text { facial bones. } \\
\text { Plate VI - Fig. } 5\end{array}$ \\
\hline & Quadrates & 3 & \\
\hline & $\begin{array}{l}\text { Scale-like fish bone } \\
\text { fragments }\end{array}$ & 21 & \\
\hline MM V-2925 & $\begin{array}{l}\text { Squalicorax volgensis } \\
\text { tooth }\end{array}$ & 1 & Plate II - Fig. 2 \\
\hline MM V-2926 & $\begin{array}{l}\text { Squalicorax volgensis } \\
\text { tooth }\end{array}$ & 1 & Plate II - Fig. 3 \\
\hline \multirow[t]{4}{*}{ MM V-2928 } & $\begin{array}{l}\text { Squalicorax volgensis } \\
\text { tooth }\end{array}$ & 1 & Plate II - Fig. 5 \\
\hline & $\begin{array}{l}\text { Squalicorax volgensis } \\
\text { tooth }\end{array}$ & 1 & \\
\hline & $\begin{array}{l}\text { "basal euteleost" } \\
\text { supraoccipitals }\end{array}$ & 2 & \\
\hline & Turtle bone fragments & 5 & Mostly anatomically indistinct \\
\hline \multirow[t]{8}{*}{ MM V-3013 } & Turtle bone fragments & 1 & $\begin{array}{c}\text { Large marginal carapace element with } \\
\text { small piece broken from corner Plate XI - } \\
\text { Fig. } 3\end{array}$ \\
\hline & $\begin{array}{l}\text { Unidentified compact- } \\
\text { shaped fish bones \& } \\
\text { fragments }\end{array}$ & 47 & \\
\hline & $\begin{array}{l}\text { Unidentified elongate- } \\
\text { shaped fish bones \& } \\
\text { fragments }\end{array}$ & 41 & \\
\hline & $\begin{array}{l}\text { Unidentified plate- } \\
\text { shaped fish bones \& } \\
\text { fragments }\end{array}$ & 98 & $\begin{array}{l}\text { Could be fragments of any number of } \\
\text { bones of the skull or opercular series }\end{array}$ \\
\hline & Urohyal fragments & 1 & \\
\hline & $\begin{array}{c}\text { Vertebrae - } \\
\text { Morphotype \#1/\#2 }\end{array}$ & 16 & \\
\hline & $\begin{array}{c}\text { Vertebrae - } \\
\text { Morphotype \#3 }\end{array}$ & 16 & \\
\hline & $\begin{array}{c}\text { Vertebrae - } \\
\text { Morphotype \#4 }\end{array}$ & 14 & $\begin{array}{c}\text { Two w/i this count are fused to one } \\
\text { another }\end{array}$ \\
\hline
\end{tabular}




\begin{tabular}{|c|c|c|c|}
\hline \multicolumn{4}{|c|}{ Specimen Inventory } \\
\hline \multicolumn{2}{|c|}{ Sample \#: VdV001 - Pt. 3 of 3 } & \multicolumn{2}{c|}{ Sieve Size: No. 10 } \\
\hline Specimen \# & Element & Count & Notes \\
\hline *all elements referred to by anatomical name only are of unidentified actinopterygian taxa unless otherwise specified \\
\hline & $\begin{array}{c}\text { Vertebrae - } \\
\text { Morphotype \#7 }\end{array}$ & 8 & \\
\hline & $\begin{array}{c}\text { Vertebrae - } \\
\text { Morphotype \#9 }\end{array}$ & 3 & \\
\hline & $\begin{array}{c}\text { Vertebrae - } \\
\text { unrecognized } \\
\text { morphotypes }\end{array}$ & 2 & \\
\hline Vertebral fragments & 37 & \\
\hline \multicolumn{2}{|c|}{ Total Count: } & 481 & \\
\hline MM - Manitoba Museum & & \\
\hline
\end{tabular}




\begin{tabular}{|c|c|c|c|}
\hline \multicolumn{4}{|c|}{ Specimen Inventory } \\
\hline \multicolumn{2}{|c|}{ Sample \#: VdV002 - Pt. 1 of 2} & \multicolumn{2}{|r|}{ Sieve Size: No. 10} \\
\hline Specimen \# & Element & Count & Notes \\
\hline \multicolumn{4}{|c|}{ *all elements referred to by anatomical name only are of unidentified actinopterygian taxa unless otherwise specified } \\
\hline MM V-2974 & $\begin{array}{l}\text { Basioccipital fragments } \\
\text { - Morphotype \#3 } \\
\text { (salmoniform) }\end{array}$ & $1^{*}$ & $\begin{array}{c}\text { "broke into } 3 \text { pieces during photography } \\
\text { Plate VII - Fig. } 2\end{array}$ \\
\hline & $\begin{array}{c}\text { Carcharias amonensis } \\
\text { tooth }\end{array}$ & 1 & \\
\hline & Caturid scales & 4 & \\
\hline MM V-2961 & Caturid vertebrae & 1 & Plate VI - Fig. 2 \\
\hline & $\begin{array}{c}\text { Coprolites } \\
\text { Coprolite fragments }\end{array}$ & $\begin{array}{c}11 \\
4\end{array}$ & \\
\hline & Elopopsis tooth & 1 & Pyritized \\
\hline & Enchodus teeth & 6 & $\begin{array}{l}\text { Tiny teeth embedded in undissolved } \\
\text { matrix }\end{array}$ \\
\hline & Pyritic film fragments & $\mathrm{n} / \mathrm{a}$ & \\
\hline & $\begin{array}{l}\text { Squalicorax volgensis } \\
\text { tooth }\end{array}$ & 1 & \\
\hline & $\begin{array}{l}\text { Unidentified articular } \\
\text { fragments }\end{array}$ & 1 & \\
\hline & $\begin{array}{l}\text { Unidentified cerato- } \\
\text { /epihyal fragments }\end{array}$ & 2 & \\
\hline & $\begin{array}{l}\text { Unidentified compact- } \\
\text { shaped fish bones \& } \\
\text { fragments }\end{array}$ & 8 & \\
\hline & $\begin{array}{l}\text { Unidentified elongate- } \\
\text { shaped fish bones \& } \\
\text { fragments }\end{array}$ & 4 & \\
\hline & $\begin{array}{l}\text { Unidentified fish scales } \\
\text { \& fragments }\end{array}$ & 17 & \\
\hline & $\begin{array}{l}\text { Unidentified opercular } \\
\text { fragments }\end{array}$ & 2 & \\
\hline & $\begin{array}{l}\text { Unidentified plate- } \\
\text { shaped fish bones \& } \\
\text { fragments }\end{array}$ & 31 & \\
\hline & $\begin{array}{l}\text { Unidentified preopercle } \\
\text { fragments }\end{array}$ & 1 & \\
\hline & $\begin{array}{l}\text { "basal euteleost" } \\
\text { supraoccipital } \\
\text { fragments }\end{array}$ & 1 & \\
\hline & $\begin{array}{c}\text { Vertebrae - } \\
\text { Morphotype \#1/\#2 } \\
\text { Vertebral fragments - } \\
\text { Morphotype \#1/\#2 }\end{array}$ & $\begin{array}{l}3 \\
2\end{array}$ & \\
\hline & $\begin{array}{c}\text { Vertebrae - } \\
\text { Morphotype \#3 }\end{array}$ & 7 & \\
\hline & $\begin{array}{c}\text { Vertebrae - } \\
\text { Morphotype \#4 } \\
\text { (salmoniform) } \\
\text { Vertebral Fragments } \\
\text { (Morphotype \#4) }\end{array}$ & 1 & $\begin{array}{c}\text { One of which is fractured into } 3 \text { large pieces, } \\
\text { another (the largest) also has a smaller piece } \\
\text { included. }\end{array}$ \\
\hline
\end{tabular}




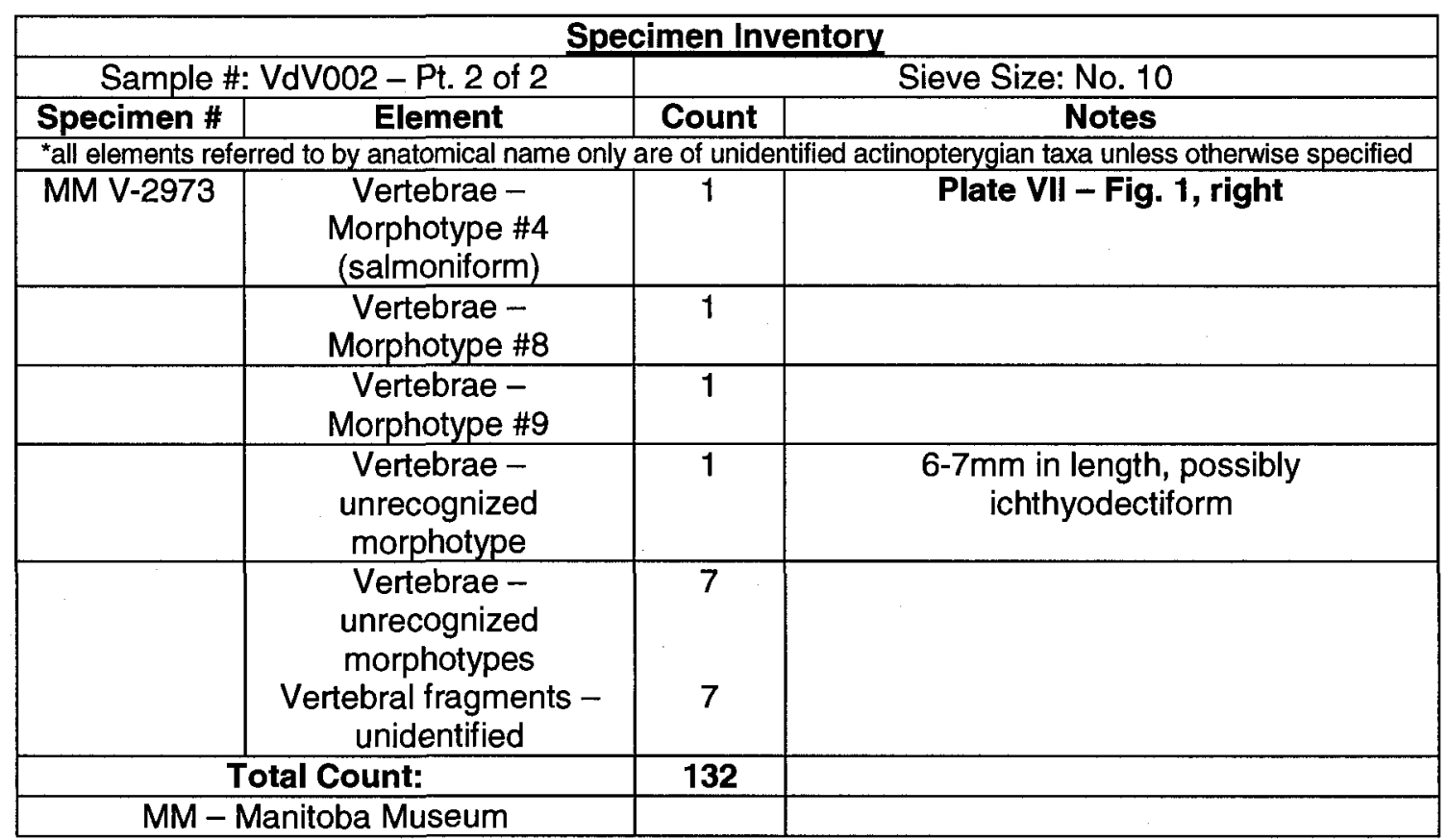




\begin{tabular}{|c|c|c|c|}
\hline \multicolumn{4}{|c|}{ Specimen Inventory } \\
\hline \multicolumn{2}{|c|}{ Sample \#: VdV003 - Pt. 1 of 1} & \multicolumn{2}{|c|}{ Sieve Size: No. 10} \\
\hline Specimen \# & Element & Count & Notes \\
\hline \multicolumn{4}{|c|}{ *all elements referred to by anatomical name only are of unidentified actinopterygian taxa unless otherwise specified } \\
\hline & $\begin{array}{l}\text { "elongo-plate" } \\
\text { element }\end{array}$ & 1 & $\begin{array}{l}\text { Elongate element with articular surface at } \\
\text { "base", attached to a large (mostly missing) } \\
\text { platey surface (see photo for clarification) }\end{array}$ \\
\hline \multirow[t]{13}{*}{ MM V-2951 } & $\begin{array}{l}\text { Carcharias sp. C } \\
\text { tooth (cf. C. } \\
\text { saskatchewanensis }\end{array}$ & 1 & $\begin{array}{c}\text { Shows small enameloid ridges on labial } \\
\text { crown base. } \\
\text { Plate V - Fig. } 1\end{array}$ \\
\hline & $\begin{array}{c}\text { Corprolites \& } \\
\text { coprolite fragments }\end{array}$ & 3 & \\
\hline & Enchodus tooth & 1 & \\
\hline & $\begin{array}{l}\text { Quartz grains \& other } \\
\text { residues }\end{array}$ & 3 & $\begin{array}{l}\text { One quartz grain, the other two strange } \\
\text { fragments are likely artifacts of acid } \\
\text { preparation }\end{array}$ \\
\hline & $\begin{array}{l}\text { Unidentified compact- } \\
\text { shaped fish bone } \\
\text { fragments }\end{array}$ & 3 & \\
\hline & $\begin{array}{c}\text { Unidentified } \\
\text { elongate-shaped fish } \\
\text { bone fragments }\end{array}$ & 2 & \\
\hline & $\begin{array}{l}\text { Unidentified fish } \\
\text { scale fragments }\end{array}$ & 3 & \\
\hline & $\begin{array}{l}\text { Unidentified plate- } \\
\text { shaped fish bone } \\
\text { fragments }\end{array}$ & 9 & \\
\hline & $\begin{array}{c}\text { Vertebrae - } \\
\text { Morphotype \#1/\#2 } \\
\text { Vertebrae - } \\
\text { Morphotype \#9 } \\
\end{array}$ & 3 & \\
\hline & $\begin{array}{c}\text { Vertebrae - } \\
\text { Morphotype \#3 }\end{array}$ & 2 & \\
\hline & $\begin{array}{c}\text { Vertebrae - } \\
\text { Morphotype \#4 }\end{array}$ & 1 & \\
\hline & $\begin{array}{c}\text { Vertebrae - } \\
\text { Morphotype \#7 }\end{array}$ & 3 & \\
\hline & $\begin{array}{c}\text { Vertebral fragments - } \\
\text { unidentified }\end{array}$ & 24 & \\
\hline \multicolumn{2}{|c|}{ Total Count: } & 60 & $\begin{array}{l}\text { (total count includes } 1 \text { quartz grain, but not } \\
\text { the other } 2 \text { strange grains }\end{array}$ \\
\hline \multicolumn{2}{|c|}{ MM - Manitoba Museum } & & \\
\hline
\end{tabular}




\begin{tabular}{|c|c|c|c|}
\hline \multicolumn{4}{|c|}{ Specimen Inventory } \\
\hline \multicolumn{2}{|c|}{ Sample \#: VdV004 - Pt. 1 of 2} & \multicolumn{2}{|r|}{ Sieve Size: No. 10} \\
\hline Specimen \# & Element & Count & Notes \\
\hline \multicolumn{4}{|c|}{ *all elements referred to by anatomical name only are of unidentified actinopterygian taxa unless otherwise specified } \\
\hline & $\begin{array}{l}\text { "Holy" fish jaw } \\
\text { element }\end{array}$ & 1 & $\begin{array}{c}\text { Belonostomous(?)...though it lacks external } \\
\text { enameloid }\end{array}$ \\
\hline \multirow[t]{2}{*}{ MM V-2948 } & $\begin{array}{c}\text { Carcharias } \\
\text { amonensis tooth }\end{array}$ & 1 & $\begin{array}{l}\text { Plate IV - Fig. } 9 \\
\end{array}$ \\
\hline & $\begin{array}{c}\text { Coprolites } \\
\text { Coprolite } \\
\text { fragments } \\
\text { Digested-looking } \\
\text { bone fragments }\end{array}$ & $\begin{array}{l}8 \\
8 \\
3\end{array}$ & $\begin{array}{c}1 \text { possesses some "ropey" texturing on some of } \\
\text { its surface }\end{array}$ \\
\hline \multirow[t]{2}{*}{ MM V-2971 } & $\begin{array}{l}\text { Elopopsis sp. } \\
\text { tooth }\end{array}$ & $\overline{1}$ & Plate VI - Fig. 10 \\
\hline & $\begin{array}{l}\text { Elopopsis sp. } \\
\text { tooth }\end{array}$ & 1 & \\
\hline \multirow[t]{2}{*}{ MM V-2987 } & $\begin{array}{c}\text { Enchodus sp. } \\
\text { jaw(?) fragments } \\
\text { w/ teeth }\end{array}$ & 1 & $\begin{array}{l}\text { Broken in two pieces. } \\
\text { Plate VIII - Fig. } 3\end{array}$ \\
\hline & $\begin{array}{l}\text { Enchodus sp. } \\
\text { tooth fragments } \\
\text { Enchodus sp. } \\
\text { palatine fragment }\end{array}$ & 5 & Appears to be E. petrosus. \\
\hline \multirow[t]{5}{*}{ MM V-2983 } & $\begin{array}{l}\text { Enchodus sp. } \\
\text { palatine }\end{array}$ & 1 & $\begin{array}{c}\text { Consistent w/ E. shumardi; though quite large \& } \\
\text { robust - Plate VII - Fig. } 9\end{array}$ \\
\hline & $\begin{array}{l}\text { Fragments of } \\
\text { "articulated" } \\
\text { Inoceramus } \\
\text { prisms } \\
\end{array}$ & 4 & $\begin{array}{c}\text { Prismatic calcareous material that survived acid } \\
\text { treatment }\end{array}$ \\
\hline & $\begin{array}{l}\text { Protosphyraena } \\
\text { sp. tooth }\end{array}$ & 1 & \\
\hline & $\begin{array}{l}\text { Pyrite film } \\
\text { fragments }\end{array}$ & $\mathrm{n} / \mathrm{a}$ & $\begin{array}{l}\text { Pyritic films that appear to have coated grains; } \\
\text { sloughed off during preparation }\end{array}$ \\
\hline & $\begin{array}{l}\text { Squalicorax } \\
\text { volgensis teeth }\end{array}$ & 2 & \\
\hline MM V-2924 & $\begin{array}{l}\text { Squalicorax } \\
\text { volgensis tooth }\end{array}$ & 1 & Plate II - Fig. 1 \\
\hline \multirow[t]{5}{*}{ MM V-2929 } & $\begin{array}{c}\text { Squalicorax } \\
\text { volgensis tooth }\end{array}$ & 1 & Plate II - Fig. 6 \\
\hline & $\begin{array}{l}\text { Unidentified } \\
\text { "elongo-plate" } \\
\text { bones }\end{array}$ & 2 & \\
\hline & $\begin{array}{c}\text { Unidentified } \\
\text { "jerry-curl" bone } \\
\text { fragment }\end{array}$ & 1 & \\
\hline & $\begin{array}{c}\text { Unidentified } \\
\text { compact-shaped } \\
\text { bone fragments }\end{array}$ & 4 & $\begin{array}{c}2 \text { of these are particularly dense; may be } \\
\text { reptilian }\end{array}$ \\
\hline & $\begin{array}{l}\text { Unidentified fish } \\
\text { scale fragments }\end{array}$ & 10 & \\
\hline
\end{tabular}




\begin{tabular}{|c|c|c|c|}
\hline \multicolumn{4}{|c|}{ Specimen Inventory } \\
\hline \multicolumn{2}{|c|}{ Sample \#: VdV004 - Pt. 2 of 2} & \multicolumn{2}{|r|}{ Sieve Size: No. 10} \\
\hline Specimen \# & Element & Count & Notes \\
\hline \multicolumn{4}{|c|}{ all elements referred to by anatomical name only are of unidentified actinopterygian taxa unless otherwise specified } \\
\hline & $\begin{array}{l}\text { "basal euteleost" } \\
\text { hyomandibular } \\
\text { bones }\end{array}$ & 1 & \\
\hline & $\begin{array}{c}\text { Unidentified } \\
\text { plate-shaped fish } \\
\text { bones \& } \\
\text { fragments }\end{array}$ & 31 & Includes 1 cerato-/epihyal fragment \\
\hline & $\begin{array}{c}\text { Unidentified, } \\
\text { plate-shaped } \\
\text { bone fragment w/ } \\
\text { highly sculptured } \\
\text { surface }\end{array}$ & 3 & Turtle? \\
\hline & $\begin{array}{c}\text { Vertebrae - } \\
\text { Morphotype } \\
\# 1 / \# 2 \\
\end{array}$ & 2 & \\
\hline & $\begin{array}{c}\text { Vertebrae - } \\
\text { Morphotype \#4 }\end{array}$ & 1 & Fractured into 4 pieces \\
\hline & $\begin{array}{c}\text { Vertebrae - } \\
\text { Morphotype \#5 }\end{array}$ & 1 & \\
\hline & $\begin{array}{c}\text { Vertebrae - } \\
\text { Morphotype \#8 }\end{array}$ & 1 & \\
\hline & $\begin{array}{l}\text { Vertebral } \\
\text { fragments - } \\
\text { unidentified }\end{array}$ & $\overline{15}$ & \\
\hline & I Count: & 112 & \\
\hline $\mathrm{MM}-\mathrm{Ma}$ & itoba Museum & & \\
\hline
\end{tabular}




\begin{tabular}{|c|c|c|c|}
\hline \multicolumn{4}{|c|}{ Specimen Inventory } \\
\hline \multicolumn{2}{|c|}{ Sample \#: VdV004 - Pt. 1 of 2} & \multirow{2}{*}{\multicolumn{2}{|c|}{$\begin{array}{l}\text { Sieve Size: No. } 20 \\
\text { Notes }\end{array}$}} \\
\hline Specimen \# & Element & & \\
\hline all elements & ferred to by anatomical name only ar & of uniden & ied actinopterygian taxa unless otherwise specified \\
\hline & $\begin{array}{l}\text { Basioccipital fragments - } \\
\text { Morphotype \#1 }\end{array}$ & 5 & \\
\hline & $\begin{array}{l}\text { Caturid scales and scale } \\
\text { fragments }\end{array}$ & 60 & \\
\hline MM V-2963 & Caturid scale & 1 & Plate VI - Fig. 4 \\
\hline & $\begin{array}{l}\text { Caturid vertebral arch } \\
\text { element }\end{array}$ & 6 & \\
\hline & $\begin{array}{c}\text { coprolites } \\
\text { Coprolite fragments }\end{array}$ & $\begin{array}{l}56 \\
23\end{array}$ & $\begin{array}{l}4 \mathrm{w} / \text { visible "ropey" texturing on at least } \\
\text { part of their surface }\end{array}$ \\
\hline & $\begin{array}{l}\text { Heavily abraded, almost } \\
\text { spherical, compact-shaped } \\
\text { bone fragments }\end{array}$ & 14 & $\begin{array}{l}\text { Look as though they may have been } \\
\text { digested }\end{array}$ \\
\hline & Enchodus scale & 1 & \\
\hline MM V-2988 & Enchodus scale & 1 & Plate VIII - Fig. 4 \\
\hline & $\begin{array}{l}\text { Enchodus sp. jaw } \\
\text { fragments }\end{array}$ & 4 & \\
\hline MM V-2985 & Enchodus sp. dentary frag. & 1 & Plate VIII - Fig. 2, top \\
\hline MM V-2986 & Enchodus sp. dentary frag. & 1 & Plate VIII - Fig. 2, bottom \\
\hline & $\begin{array}{l}\text { Enchodus sp. teeth } \\
\text { Enchodus sp. tooth } \\
\text { fragments }\end{array}$ & $\begin{array}{l}10 \\
20\end{array}$ & $\begin{array}{c}\text { Up to } 13 \text { of these may all be pieces of one } \\
\text { large tooth }\end{array}$ \\
\hline & $\begin{array}{l}\text { "Teleost A" teeth \& } \\
\text { fragments } \\
\text { Unidentified shark tooth } \\
\text { fragment }\end{array}$ & $\begin{array}{l}5 \\
1\end{array}$ & \\
\hline & $\begin{array}{l}\text { Unidentified "holy" bone jaw } \\
\text { fragments }\end{array}$ & 2 & \\
\hline & "basal euteleost" dentaries & 11 & \\
\hline & articular fragments & 5 & Includes "basal euteleost" \\
\hline & $\begin{array}{c}\text { Unidentified cerato-epihyal } \\
\text { fragments }\end{array}$ & 21 & \\
\hline & $\begin{array}{l}\text { Unidentified compact- } \\
\text { shaped fish bones \& } \\
\text { fragments }\end{array}$ & 122 & \\
\hline & $\begin{array}{l}\text { anguilliform vertebral } \\
\text { fragments }\end{array}$ & 6 & \\
\hline MM V-2992 & $\begin{array}{l}\text { anguilliform vertebral } \\
\text { fragment }\end{array}$ & 1 & Plate VIII - Fig. 8 \\
\hline & $\begin{array}{c}\text { Unidentified elongate- } \\
\text { shaped fish bones \& } \\
\text { fragments }\end{array}$ & 155 & \\
\hline & $\begin{array}{l}\text { Unidentified epibranchial } \\
\text { fragments }\end{array}$ & 3 & \\
\hline & $\begin{array}{l}\text { Unidentified fish scale } \\
\text { fragments }\end{array}$ & 277 & \\
\hline & $\begin{array}{l}\text { Unidentified "gill raker" } \\
\text { fragments }\end{array}$ & 3 & \\
\hline
\end{tabular}




\begin{tabular}{|c|c|c|c|}
\hline \multicolumn{4}{|c|}{ Specimen Inventory } \\
\hline \multicolumn{2}{|c|}{ Sample \#: VdV004 - Pt. 2 of 2} & \multicolumn{2}{|r|}{ Sieve Size: No. 20} \\
\hline Specimen \# & Element & Count & Notes \\
\hline \multicolumn{4}{|c|}{ *all elements referred to by anatomical name only are of unidentified actinopterygian taxa unless otherwise specified } \\
\hline MM V-2998 & $\begin{array}{l}\text { "basal euteleost" maxilla } \\
\text { frag. }\end{array}$ & 1 & Plate IX - Fig. 6, upper left \\
\hline MM V-2999 & $\begin{array}{l}\text { "basal euteleost" maxilla } \\
\text { frag. }\end{array}$ & 1 & Plate IX - Fig. 6, upper right \\
\hline \multirow[t]{16}{*}{ MM V-3000 } & $\begin{array}{l}\text { "basal euteleost" maxilla } \\
\text { frag. }\end{array}$ & 1 & Plate IX - Fig. 6, bottom \\
\hline & $\begin{array}{l}\text { "basal euteleost" } \\
\text { hyomandibular fragments }\end{array}$ & 7 & \\
\hline & $\begin{array}{l}\text { Unidentified opercular } \\
\text { fragments }\end{array}$ & 6 & \\
\hline & $\begin{array}{l}\text { Unidentified plate-shaped } \\
\text { fish bone fragments }\end{array}$ & 681 & \\
\hline & $\begin{array}{l}\text { Unidentified prevomer } \\
\text { fragments } \\
\text { Unidentified basipterygium } \\
\text { Unidentified spine bases } \\
\text { Elopopsis jaw fragments }\end{array}$ & $\begin{array}{l}2 \\
1 \\
3 \\
5\end{array}$ & $\begin{array}{c}1 \text { Morphotype \#1 (the more common) \& } 1 \\
\text { Morphtype \#2 ("the beak") }\end{array}$ \\
\hline & $\begin{array}{l}\text { Unidentified quadrate } \\
\text { fragments }\end{array}$ & 6 & Includes "basal euteleost" \\
\hline & $\begin{array}{l}\text { "basal euteleost" } \\
\text { supraoccipitals }\end{array}$ & 5 & \\
\hline & $\begin{array}{l}\text { Unidentified urohyal } \\
\text { fragments }\end{array}$ & 6 & \\
\hline & $\begin{array}{c}\text { Vertebrae - Morphotype } \\
\# 1 / \# 2\end{array}$ & 19 & \\
\hline & Vertebrae - Morphotype \#3 & 14 & \\
\hline & Vertebrae - Morphotype \#4 & 2 & \\
\hline & Vertebrae - Morphotype \#5 & 14 & \\
\hline & Vertebrae - Morphotype \#7 & 6 & \\
\hline & Vertebrae - Morphotype \#8 & 6 & \\
\hline & $\begin{array}{c}\text { Vertebrae - unrecognized } \\
\text { morphotypes }\end{array}$ & 5 & \\
\hline & $\begin{array}{l}\text { Vertebral fragments - } \\
\text { unidentified }\end{array}$ & 227 & $\begin{array}{c}\text { Most fragments that are of much larger } \\
\text { vertebrae appear very much like } \\
\text { Morphotype \#4 }\end{array}$ \\
\hline & & 1833 & \\
\hline \multicolumn{2}{|c|}{ MM - Manitoba Museum } & & \\
\hline
\end{tabular}




\begin{tabular}{|c|c|c|c|}
\hline \multicolumn{4}{|c|}{ Specimen Inventory } \\
\hline \multicolumn{2}{|r|}{ Sample \#: VdV005 - Pt. 1 of 1} & \multicolumn{2}{|c|}{ Sieve Size: No. 10} \\
\hline Specimen \# & Element & Count & Notes \\
\hline \multirow{2}{*}{\multicolumn{4}{|c|}{$\begin{array}{l}\text { *all elements referred to by anatomical name only are of unidentified actinopterygian taxa unless otherwise specified } \\
\qquad \begin{array}{c|c|}\text { Archaeolamna sp. teeth } \\
\end{array}\end{array}$}} \\
\hline & & & \\
\hline \multirow[t]{3}{*}{ MM V-2933 } & Archaeolamna sp. tooth & 1 & Plate III - Fig. 2 \\
\hline & $\begin{array}{c}\text { Basioccipital - Morphptype \#1 } \\
\text { Unidentified prevomer - Morphotype } \\
\# 1\end{array}$ & $\begin{array}{l}1 \\
1\end{array}$ & \\
\hline & Carcharias amonensis teeth & 2 & \\
\hline MM V-2945 & Carcharias amonensis tooth & 1 & Plate IV - Fig. 6 \\
\hline \multirow{18}{*}{ MM V-2949 } & Carcharias amonensis tooth & 1 & Plate IV - Fig. 10 \\
\hline & Carcharias sp. A & 1 & \\
\hline & Coprolites & 19 & \\
\hline & $\begin{array}{l}\text { Elopopsis sp. teeth } \\
\text { Unidentified fish tooth } \\
\text { "Teleost A" tooth }\end{array}$ & $\begin{array}{l}1 \\
1 \\
1\end{array}$ & \\
\hline & $\begin{array}{c}\text { Enchodus sp. teeth } \\
\text { Enchodus sp. palatines }\end{array}$ & $\begin{array}{l}5 \\
2\end{array}$ & \\
\hline & Mineral grains & $\mathrm{n} / \mathrm{a}$ & \\
\hline & Squalicorax volgensis teeth & 2 & \\
\hline & Unidentified ceratohyals & 3 & \\
\hline & $\begin{array}{c}\text { Unidentified compact-shaped bones \& } \\
\text { fragments }\end{array}$ & 9 & \\
\hline & $\begin{array}{c}\text { Unidentified elongate spines \& } \\
\text { fragments }\end{array}$ & 2 & \\
\hline & $\begin{array}{l}\text { Unidentified elongate-shaped bones \& } \\
\text { fragments }\end{array}$ & 11 & \\
\hline & "basal euteleost" hyomandibular & 1 & \\
\hline & $\begin{array}{l}\text { Unidentified plate-shaped bones \& } \\
\text { fragments }\end{array}$ & 32 & 2 vials \\
\hline & Unidentified scale fragments & 4 & \\
\hline & Unidentified shark tooth(?) fragment & 1 & \\
\hline & "basal euteleost" supraoccipital & 1 & \\
\hline & Unidentified uroneural fragment & 1 & \\
\hline & Vertebrae - Morphotype \#1 & 9 & \\
\hline \multirow[t]{4}{*}{ MM V-2970 } & Vertebrae - Morphotype \#11 & 1 & $\begin{array}{l}\text { Ichthyodectiform? } \\
\text { Plate VI - Fig. } 9\end{array}$ \\
\hline & Vertebrae - Morphotype \#2 & 6 & \\
\hline & Vertebrae - Morphotype \#3 & 11 & \\
\hline & $\begin{array}{c}\text { Vertebrae - Morphotype \#4 } \\
\text { Vertebral fragments - Morphotype \#4 }\end{array}$ & $\begin{array}{l}5 \\
1\end{array}$ & \\
\hline \multirow[t]{8}{*}{ MM V-2972 } & Vertebra - Morphotype \#4 & 1 & Plate VII - Fig. 1 (left) \\
\hline & Vertebrae - Morphotype \#5 & 8 & \\
\hline & Vertebrae - Morphotype \#7 & 3 & \\
\hline & Vertebrae - Morphotype \#8 & 1 & \\
\hline & Vertebrae - Morphotype \#9 & 1 & \\
\hline & Vertebrae - unrecognized morphotype & 1 & \\
\hline & Vertebral fragments - unidentified & 6 & \\
\hline & $\begin{array}{c}\text { Total Count: } \\
\text { MM - Manitoba Museum }\end{array}$ & 163 & $\begin{array}{l}\text { *This sample was used in the } \\
\text { comparative taphonomic } \\
\text { census }\end{array}$ \\
\hline
\end{tabular}




\begin{tabular}{|c|c|c|c|}
\hline \multicolumn{4}{|c|}{ Specimen Inventory } \\
\hline \multicolumn{2}{|c|}{ Sample \#: VdV005-A - Pt. 1 of 4} & \multicolumn{2}{|r|}{ Sieve Size: No. 20} \\
\hline Specimen \# & Element & Count & Notes \\
\hline \multicolumn{4}{|c|}{ *all elements referred to by anatomical name only are of unidentified actinopterygian taxa unless otherwise specified } \\
\hline & Basioccipitals & 12 & 11 Morphotype \#1; 1 Morphotype \#2 \\
\hline & $\begin{array}{l}\text { Caturid scales \& scale } \\
\text { fragments }-1-2 \mathrm{~mm}\end{array}$ & 25 & \\
\hline & $\begin{array}{c}\text { Caturid scales \& scale } \\
\text { fragments }-2-3 \mathrm{~mm}\end{array}$ & 11 & \\
\hline \multirow[t]{2}{*}{ MM V-2962 } & Caturid scale & 1 & Plate VI - Fig. 3 \\
\hline & $\begin{array}{l}\text { Caturid scales \& scale } \\
\text { fragments }-3-4 \mathrm{~mm}\end{array}$ & 4 & \\
\hline MM V-2957 & $\begin{array}{c}\text { Caturid vertebral arch } \\
\text { element }\end{array}$ & 1 & Plate VI - Fig. 1, upper left \\
\hline MM V-2958 & $\begin{array}{c}\text { Caturid vertebral arch } \\
\text { element }\end{array}$ & 1 & Plate VI - Fig. 1, upper right \\
\hline MM V-2959 & $\begin{array}{c}\text { Caturid vertebral arch } \\
\text { element }\end{array}$ & 1 & Plate VI - Fig. 1, lower right \\
\hline \multirow[t]{9}{*}{ MM V-2960 } & $\begin{array}{c}\text { Caturid vertebral arch } \\
\text { element }\end{array}$ & 1 & Plate VI - Fig. 1, lower left \\
\hline & $\begin{array}{c}\text { Caturid vertebral arch } \\
\text { element }\end{array}$ & 1 & \\
\hline & $\begin{array}{c}\text { Coprolites - compact- } \\
\text { shaped }\end{array}$ & 25 & \\
\hline & $\begin{array}{c}\text { Coprolites - plate- } \\
\text { shaped }\end{array}$ & 19 & \\
\hline & $\begin{array}{c}\text { Dubious caturid scales \& } \\
\text { scale fragments }\end{array}$ & 32 & \\
\hline & $\begin{array}{l}\text { Enchodus sp. teeth \& } \\
\text { jaw fragments }\end{array}$ & 5 & 1 tooth, 4 jaw fragments $w /$ some small teeth \\
\hline & $\begin{array}{c}\text { Enchodus sp.(?) scale } \\
\text { fragments }\end{array}$ & 2 & \\
\hline & Fin spine base fragment & 1 & Acanthomorph? \\
\hline & $\begin{array}{c}\text { Prevomer - Morphotype } \\
\# 1\end{array}$ & 1 & \\
\hline MM V-3007 & "Teleost A" tooth & 1 & Plate X - Fig. 6, left \\
\hline MM V-3008 & "Teleost A" tooth & 1 & Plate X - Fig. 6, centre \\
\hline MM V-3009 & "Teleost A" tooth & 1 & Plate X-Fig. 6, right \\
\hline \multirow[t]{3}{*}{ MM V-3010 } & "Teleost A" jaw fragment & 1 & Plate X-Fig. 7 \\
\hline & $\begin{array}{c}\text { Unidentified "jerry-curl" } \\
\text { bone fragment }\end{array}$ & 1 & \\
\hline & $\begin{array}{c}\text { "basal euteleost" } \\
\text { dentaries \& fragments - } \\
1-2 \mathrm{~mm}\end{array}$ & 10 & \\
\hline \multirow[t]{2}{*}{ MM V-2993 } & $\begin{array}{c}\text { "basal euteleost" dentary } \\
-1-2 m m\end{array}$ & 1 & Plate IX - Fig. 1 \\
\hline & $\begin{array}{c}\text { "basal euteleost" } \\
\text { dentaries \& fragments - } \\
2-3 \mathrm{~mm} \\
\end{array}$ & 10 & \\
\hline \multirow[t]{2}{*}{ MM V-2994 } & $\begin{array}{c}\text { "basal euteleost" dentary } \\
-2-3 \mathrm{~mm}\end{array}$ & 1 & Plate IX - Fig. 2 \\
\hline & $\begin{array}{c}\text { "basal euteleost" } \\
\text { dentaries \& fragments - } \\
3-4 \mathrm{~mm} \\
\end{array}$ & 8 & \\
\hline
\end{tabular}




\begin{tabular}{|c|c|c|c|}
\hline \multicolumn{4}{|c|}{ Specimen Inventory } \\
\hline \multicolumn{2}{|c|}{ Sample \#: VdV005-A - Pt. 2 of 4} & \multicolumn{2}{|r|}{ Sieve Size: No. 20} \\
\hline Specimen \# & Element & Count & Notes \\
\hline \multicolumn{4}{|c|}{ "all elements referred to by anatomical name only are of unidentified actinopterygian taxa unless otherwise specified } \\
\hline & $\begin{array}{l}\text { Unidentified "spine" } \\
\text { fragments }\end{array}$ & 58 & 6 size classes in 4 separate vials \\
\hline & $\begin{array}{c}\text { "basal euteleost" } \\
\text { articulars \& fragments }\end{array}$ & 7 & \\
\hline MM V-3002 & $\begin{array}{l}\text { "basal euteleost" } \\
\text { articular }\end{array}$ & 1 & Plate X - Fig. 1 \\
\hline \multirow[t]{5}{*}{ MM V-3003 } & $\begin{array}{l}\text { "basal euteleost" } \\
\text { articular }\end{array}$ & 1 & Plate X - Fig. 2 \\
\hline & $\begin{array}{l}\text { Unidentified compact- } \\
\text { shaped fish bones \& } \\
\text { fragments }-1-2 \mathrm{~mm}\end{array}$ & 64 & \\
\hline & $\begin{array}{c}\text { Unidentified compact- } \\
\text { shaped fish bones \& } \\
\text { fragments }-2-3 \& 3- \\
4 \mathrm{~mm} \\
\end{array}$ & 30 & 28 2-3mm; 2 3-4mm \\
\hline & $\begin{array}{l}\text { Unidentified dubious } \\
\text { preopercular fragments }\end{array}$ & 9 & \\
\hline & $\begin{array}{l}\text { anguilliform vertebral } \\
\text { fragments }\end{array}$ & 15 & \\
\hline MM V-2989 & $\begin{array}{l}\text { anguilliform vertebral } \\
\text { fragment }\end{array}$ & 1 & Plate VIII - Fig. 5 \\
\hline MM V-2990 & $\begin{array}{l}\text { anguilliform vertebral } \\
\text { fragment }\end{array}$ & 1 & Plate VIII - Fig. 6 \\
\hline \multirow[t]{7}{*}{ MM V-2991 } & $\begin{array}{l}\text { anguilliform vertebral } \\
\text { fragment }\end{array}$ & 1 & Plate VIII - Fig. 7 \\
\hline & $\begin{array}{l}\text { Unidentified elongate- } \\
\text { shaped bones } \\
\text { \& fragments } \\
\end{array}$ & 123 & 6 size classes in 4 separate vials \\
\hline & $\begin{array}{c}\text { Unidentified elongate- } \\
\text { shaped fish bones \& } \\
\text { fragments } \\
\text { (additional) }\end{array}$ & 7 & \\
\hline & $\begin{array}{l}\text { Unidentified elongate- } \\
\text { shaped fish scale } \\
\text { fragments }\end{array}$ & 7 & \\
\hline & $\begin{array}{l}\text { Unidentified epi- } \\
\text { /ceratohyals \& fragments }\end{array}$ & 18 & \\
\hline & $\begin{array}{c}\text { Unidentified epibranchial } \\
\text { bones }\end{array}$ & 7 & \\
\hline & $\begin{array}{l}\text { "basal euteleost" } \\
\text { hyomandibulars \& } \\
\text { fragments }\end{array}$ & 23 & \\
\hline MM V-2995 & $\begin{array}{l}\text { "basal euteleost" } \\
\text { hyomandibular }\end{array}$ & 1 & Plate IX - Fig. 3 \\
\hline \multirow[t]{3}{*}{ MM V-2996 } & $\begin{array}{l}\text { "basal euteleost" } \\
\text { hyomandibular }\end{array}$ & 1 & Plate IX - Fig. 4 \\
\hline & Unidentified hypurals & 7 & \\
\hline & $\begin{array}{l}\text { Unidentified opercular } \\
\text { fragments }\end{array}$ & 10 & \\
\hline
\end{tabular}




\begin{tabular}{|c|c|c|c|}
\hline \multicolumn{4}{|c|}{ Specimen Inventory } \\
\hline \multicolumn{2}{|c|}{ Sample \#: VdV005-A - Pt. 3 of 4} & \multicolumn{2}{|r|}{ Sieve Size: No. 20} \\
\hline Specimen \# & Element & Count & Notes \\
\hline \multicolumn{4}{|c|}{ *all elements referred to by anatomical name only are of unidentified actinopterygian taxa unless otherwise specified } \\
\hline & $\begin{array}{l}\text { Unidentified plate- } \\
\text { shaped fish bones \& } \\
\text { fragments }-1-2 \mathrm{~mm}\end{array}$ & 235 & \\
\hline & $\begin{array}{l}\text { Unidentified plate- } \\
\text { shaped fish bones \& } \\
\text { fragments - } 2-3 \mathrm{~mm}\end{array}$ & 196 & \\
\hline & $\begin{array}{l}\text { Unidentified plate- } \\
\text { shaped fish bones \& } \\
\text { fragments - 3-4 \& 4- } \\
5 \mathrm{~mm}\end{array}$ & 45 & 44 3-4mm; $14-5 \mathrm{~mm}$ \\
\hline & $\begin{array}{c}\text { Unidentified plate- } \\
\text { shaped fish bones \& } \\
\text { fragments (additional) }\end{array}$ & 11 & \\
\hline & $\begin{array}{c}\text { Unidentified plate- } \\
\text { shaped fish scales \& } \\
\text { scale fragments - } 1 \text { - } \\
\text { 2mm }\end{array}$ & 82 & \\
\hline & $\begin{array}{c}\text { Unidentified plate- } \\
\text { shaped fish scales \& } \\
\text { scale fragments - 2- } \\
\text { 3mm }\end{array}$ & 38 & \\
\hline & $\begin{array}{c}\text { Unidentified plate- } \\
\text { shaped fish scales \& } \\
\text { scale fragments - } 3- \\
4 \mathrm{~mm}\end{array}$ & 5 & \\
\hline MM V-3001 & $\begin{array}{l}\text { "basal euteleost" } \\
\text { preopercular fragment }\end{array}$ & 1 & Plate IX - Fig. 7 \\
\hline & $\begin{array}{l}\text { "basal euteleost" } \\
\text { preopercular fragment }\end{array}$ & 1 & \\
\hline & quadrates \& fragments & 23 & $\begin{array}{c}3 \text { size classes in } 2 \text { separate vials; includes } \\
\text { "basal euteleost" }\end{array}$ \\
\hline MM V-3006 & $\begin{array}{l}\text { "basal euteleost" } \\
\text { supraoccipital }\end{array}$ & 1 & Plate X - Fig. 5 \\
\hline & $\begin{array}{l}\text { "basal euteleost" } \\
\text { supraoccipital }\end{array}$ & 1 & \\
\hline & Unidentified urostyle & 1 & \\
\hline & $\begin{array}{c}\text { Vertebrae - Morphotype } \\
\# 1\end{array}$ & 37 & 3 size classes; each in separate vial \\
\hline & $\begin{array}{l}\text { Vertebrae - Morphotype } \\
\text { \#2 }\end{array}$ & 25 & 2 size classes; each in separate vial \\
\hline & $\begin{array}{c}\text { Vertebrae - Morphotype } \\
\# 3\end{array}$ & 43 & 3 size classes; each in separate vial \\
\hline & $\begin{array}{c}\text { Vertebrae - Morphotype } \\
\# 4\end{array}$ & 3 & 1 size class; in own vial \\
\hline & $\begin{array}{c}\text { Vertebrae - Morphotype } \\
\# 5\end{array}$ & 45 & 4 size classes; each in separate vial \\
\hline & $\begin{array}{c}\text { Vertebrae - Morphotype } \\
\# 6\end{array}$ & 18 & 2 size classes; each in separate vial \\
\hline & $\begin{array}{c}\text { Vertebrae - Morphotype } \\
\# 7\end{array}$ & 17 & 2 size classes; each in separate vial \\
\hline
\end{tabular}




\begin{tabular}{|c|c|c|c|}
\hline \multicolumn{4}{|c|}{ Specimen Inventory } \\
\hline \multicolumn{2}{|c|}{ Sample \#: VdV005-A - Pt. 4 of 4} & \multicolumn{2}{|r|}{ Sieve Size: No. 20} \\
\hline Specimen \# & Element & Count & Notes \\
\hline \multicolumn{4}{|c|}{ *all elements referred to by anatomical name only are of unidentified actinopterygian taxa unless otherwise specified } \\
\hline & $\begin{array}{c}\text { Vertebrae - Morphotype } \\
\# 8\end{array}$ & 21 & 3 size classes; each in separate vial \\
\hline & $\begin{array}{c}\text { Vertebrae - Morphotype } \\
\# 9 \\
\text { Vertebrae - unrecognized } \\
\text { morphotypes - 1-2mm }\end{array}$ & $\begin{array}{l}1 \\
3\end{array}$ & \\
\hline & $\begin{array}{c}\text { Vertebrae - } \\
\text { unrecognized } \\
\text { morphotypes - 0-1mm }\end{array}$ & 7 & \\
\hline & $\begin{array}{l}\text { Vertebral fragments - } \\
\text { unidentified }-0-1 \mathrm{~mm}- \\
\text { compact-shaped }\end{array}$ & 13 & \\
\hline & $\begin{array}{l}\text { Vertebral fragments - } \\
\text { unidentified - 0-1mm - } \\
\text { plate-shaped }\end{array}$ & 11 & \\
\hline & $\begin{array}{l}\text { Vertebral fragments - } \\
\text { unidentified - } 1-2 \mathrm{~mm}- \\
\text { compact-shaped }\end{array}$ & 54 & $\begin{array}{l}\text { The most heavily abraded tend to be small } \\
\text { pieces of much larger vertebrae }\end{array}$ \\
\hline & $\begin{array}{l}\text { Vertebral fragments - } \\
\text { unidentified - 1-2mm - } \\
\text { plate-shaped }\end{array}$ & 84 & \\
\hline & $\begin{array}{l}\text { Vertebral fragments - } \\
\text { unidentified }-2-3 \mathrm{~mm}\end{array}$ & 13 & $\begin{array}{l}\text { Includes one piece of a Morphotype \#4 } \\
\text { vertebrae that would have once been quite } \\
\text { large }\end{array}$ \\
\hline & $\begin{array}{l}\text { Vertebral fragments - } \\
\text { unidentified }-3-4 \mathrm{~mm}\end{array}$ & 3 & \\
\hline & Total Count: & 1608 & $\begin{array}{l}\text { *This sample was used in the comparative } \\
\text { taphonomic census }\end{array}$ \\
\hline MM- & Manitoba Museum & & \\
\hline
\end{tabular}




\begin{tabular}{|c|c|c|c|}
\hline \multicolumn{4}{|c|}{ Specimen Inventory } \\
\hline \multicolumn{2}{|c|}{ Sample \#: VdV005-B - Pt. 1 of 2} & \multicolumn{2}{|r|}{ Sieve Size: No. 20} \\
\hline Specimen \# & Element & Count & Notes \\
\hline \multicolumn{4}{|c|}{ "all elements referred to by anatomical name only are of unidentified actinopterygian taxa unless otherwise specifiec } \\
\hline & $\begin{array}{c}\text { Basioccipital - } \\
\text { fragments } \\
\text { Unidentified prevomer } \\
\text { fragments } \\
\text { Fin spine base } \\
\text { fragments }\end{array}$ & $\begin{array}{l}25 \\
4 \\
2\end{array}$ & $\begin{array}{c}14 \text { Morphotype \#1; } 7 \text { Morphotype \#2; } 4 \\
\text { unidentified } \\
\text { All morphotype \#1 } \\
1 \text { of } 2 \text { destroyed during examination. } \\
\text { (Acanthomorph?) }\end{array}$ \\
\hline & $\begin{array}{c}\text { Caturid centra } \\
\text { Caturid scales } \\
\text { Caturid vertebral arch } \\
\text { elements }\end{array}$ & $\begin{array}{c}1 \\
41 \\
10\end{array}$ & \\
\hline & $\begin{array}{c}\text { Coprolites \& coprolite } \\
\text { fragments }\end{array}$ & 102 & \\
\hline MM V-3014 & Coprolite & 1 & Plate XI - Fig. 6 \\
\hline MM V-3015 & Coprolite & 1 & Plate XI-Fig. 7, left \\
\hline MM V-3016 & Coprolite & 1 & Plate XI - Fig. 7, right \\
\hline & $\begin{array}{l}\text { Enchodus sp. teeth \& } \\
\text { tooth fragments } \\
\text { "Teleost B" tooth }\end{array}$ & $\begin{array}{l}9 \\
1\end{array}$ & \\
\hline MM V-3012 & "Teleost B" tooth & 1 & Plate X - Fig. 9 \\
\hline & Quartz grain & 1 & $\sim 1.5 \mathrm{~mm}^{3}$, subrounded \\
\hline & $\begin{array}{l}\text { Unidentified "jerry-curl" } \\
\text { bone fragments } \\
\text { Unidentified } \\
\text { epibranchials } \\
\text { "basal euteleost" } \\
\text { hyomandibulars \& } \\
\text { fragments } \\
\text { anguilliform vertebral } \\
\text { fragments }\end{array}$ & $\begin{array}{c}3 \\
2 \\
35 \\
25\end{array}$ & \\
\hline MM V-2997 & $\begin{array}{l}\text { "basal euteleost" } \\
\text { hyomandibular }\end{array}$ & 1 & Plate IX - Fig. 5 \\
\hline & $\begin{array}{c}\text { articulars \& fragments } \\
\text { "basal euteleost" } \\
\text { dentaries \& fragments } \\
\text { quadrates \& fragments }\end{array}$ & $\begin{array}{l}19 \\
27 \\
17\end{array}$ & $\begin{array}{l}\text { Includes "basal euteleost" specimens } \\
\text { Includes "basal euteleost" specimens }\end{array}$ \\
\hline MM V-3004 & $\begin{array}{l}\text { "basal euteleost" } \\
\text { quadrates }\end{array}$ & 1 & Plate X-Fig. 3 \\
\hline MM V-3005 & $\begin{array}{l}\text { "basal euteleost" } \\
\text { quadrates }\end{array}$ & 1 & Plate X - Fig. 4 \\
\hline & $\begin{array}{l}\text { Unidentified compact- } \\
\text { shaped fish bones \& } \\
\text { fragments }\end{array}$ & 146 & \\
\hline
\end{tabular}




\begin{tabular}{|c|c|c|c|}
\hline \multicolumn{4}{|c|}{ Specimen Inventory } \\
\hline \multicolumn{2}{|c|}{ Sample \#: VdV005-B - Pt. 2 of 2} & \multicolumn{2}{|r|}{ Sieve Size: No. 20} \\
\hline Specimen \# & Element & Count & \\
\hline *all elements $r$ & ferred to by anatomical name & nly are of & identified actinopterygian taxa unless otherwise specified \\
\hline & $\begin{array}{l}\text { Unidentified elongate } \\
\text { "spines" \& fragments }\end{array}$ & 72 & \\
\hline & $\begin{array}{l}\text { Unidentified elongate- } \\
\text { shaped fish bones \& } \\
\text { fragments }\end{array}$ & 188 & \\
\hline & $\begin{array}{c}\text { Unidentified fish } \\
\text { scales \& fragments }\end{array}$ & 210 & \\
\hline & $\begin{array}{l}\text { Unidentified gill raker } \\
\text { fragments }\end{array}$ & 13 & \\
\hline & "holish" fragments & 2 & $\begin{array}{l}\text { Not the same as "holy jaws"; hole covered } \\
\text { patches of fish bone of unknown anatomical } \\
\text { affinity }\end{array}$ \\
\hline & $\begin{array}{c}\text { Unidentified opercular } \\
\text { fragments } \\
\text { Unidentified } \\
\text { interoperculae } \\
\text { Unidentified } \\
\text { preoperculae \& } \\
\text { fragments } \\
\text { Unidentified dubious } \\
\text { preopercular } \\
\text { fragments }\end{array}$ & $\begin{array}{l}33 \\
3 \\
7 \\
9\end{array}$ & \\
\hline & $\begin{array}{l}\text { Unidentified plate- } \\
\text { shaped fish bones \& } \\
\text { fragments }\end{array}$ & 488 & \\
\hline & $\begin{array}{c}\text { Unidentified urohyals } \\
\text { \& fragments } \\
\text { Unidentified } \\
\text { epi/ceratohyal } \\
\text { fragments } \\
\text { Unidentified } \\
\text { ceratohyals } \\
\end{array}$ & $\begin{array}{c}7 \\
36 \\
19\end{array}$ & \\
\hline & $\begin{array}{l}\text { Vertebrae- } \\
\text { unrecognized } \\
\text { morphotypes }\end{array}$ & 11 & \\
\hline & $\begin{array}{l}\text { Vertebral fragments - } \\
\text { unidentified }\end{array}$ & 327 & \\
\hline & $\begin{array}{c}\text { Vertebral Morphotype } \\
\quad \# 1 / \# 2\end{array}$ & 88 & \\
\hline & $\begin{array}{c}\text { Vertebral Morphotype } \\
\# 3\end{array}$ & 106 & \\
\hline & $\begin{array}{c}\text { Vertebral Morphotype } \\
\# 5\end{array}$ & 103 & \\
\hline & $\begin{array}{c}\text { Vertebral Morphotype } \\
\text { \#6 }\end{array}$ & 13 & \\
\hline & $\begin{array}{c}\text { Vertebral Morphotype } \\
\# 7\end{array}$ & 54 & \\
\hline & $\begin{array}{c}\text { Vertebral Morphotype } \\
\quad \# 8\end{array}$ & 7 & \\
\hline & otal Count: & 2273 & \\
\hline$M M-N$ & Manitoba Mus & & \\
\hline
\end{tabular}




\section{$\underline{\text { Additional Specimens }}$}

- Block of unprepared Van Der Voort Farm locality calcarenite w/ impression of plesiosaur tooth (MM V-3020) - Plate XI - Fig. 4

- Sample of unprepared Little Woody River locality calcarenite examined for lithological, sedimentological, and paleontological comparison with Van Der Voort material (MM V-3018) - Plate III - Fig. 9

MM - Manitoba Museum 
APPENDIX III:

CEMENT ANALYSIS DATA 


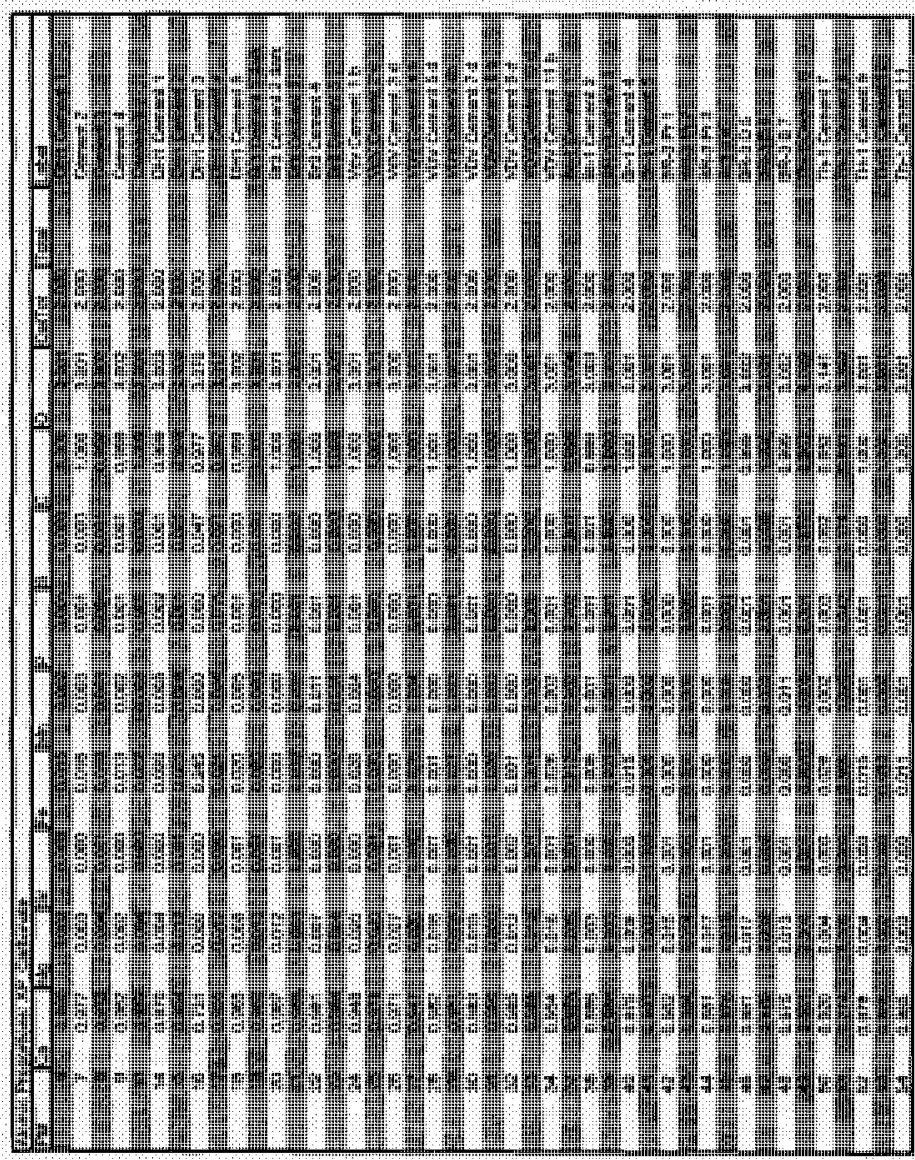

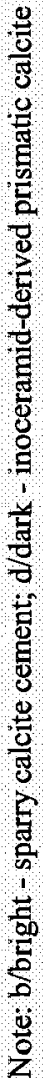

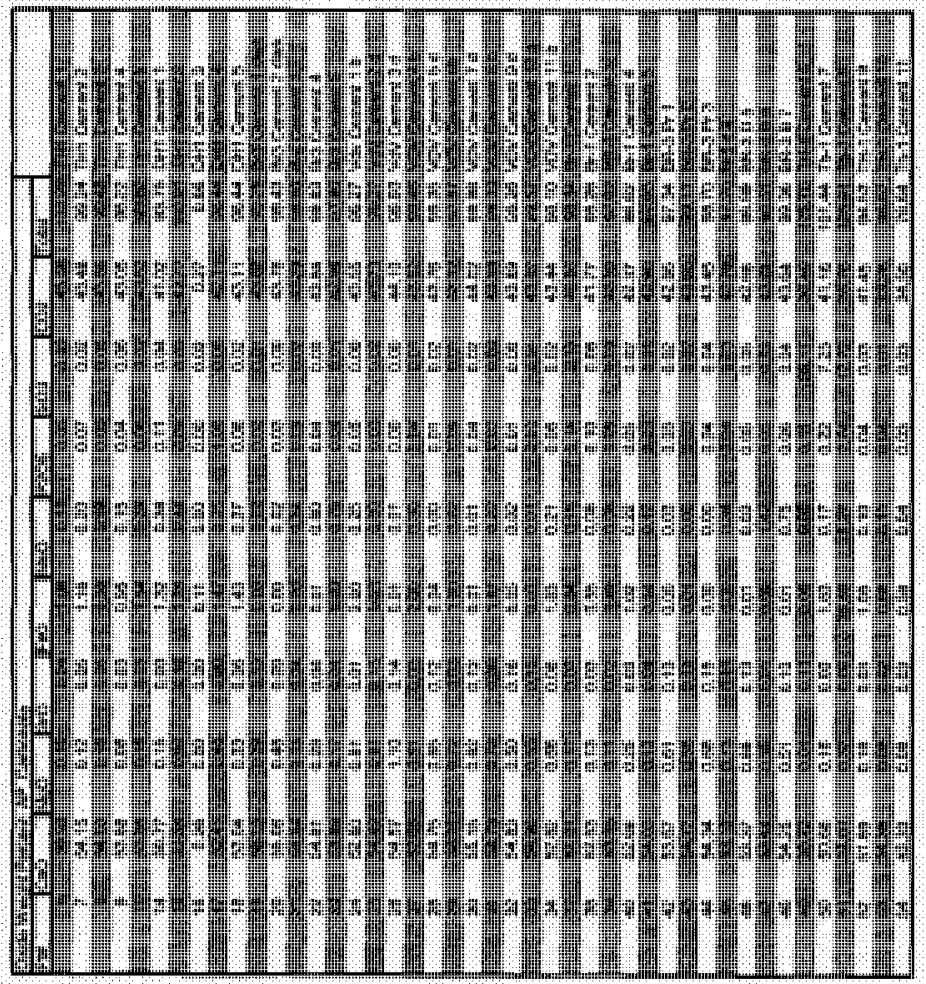

